$$
\begin{aligned}
& \text { UNIVERSIDADE DE SÃO PAULO } \\
& \text { INSTITUTO DE GEOCIÊNCIAS }
\end{aligned}
$$

\title{
IDADES E CINEMÁTICA DO PROCESSO DE ANATEXIA DE CROSTA CONTINENTAL PROFUNDA NO DOMÍNIO NORTE DA NAPPE SOCORRO- GUAXUPÉ, ORÓGENO BRASÍLIA MERIDIONAL
}

Claudio Alejandro Salazar Mora

Orientador: Prof. Dr. Mario da Costa Campos Neto

\section{DISSERTAÇÃO DE MESTRADO}

Programa de Pós-graduação em Geoquímica e Geotectônica 
Dedico este trabalho à memória da minha amada irmã, Pam. 


\section{AGRADECIMENTOS}

A seguir, expresso meus sinceros agradecimentos àquelas pessoas que, direta ou indiretamente, me influenciaram de forma positiva durante esses anos de mestrado:

Primeiramente, agradeço à minha mãe Miriam, meu pai Luis Alejandro, minhas maravilhosas irmãs Katya e Pamela (in memorian) e ao nosso cão Lino, por constituirem essa família linda e sempre unida, não importa a situação. Obrigado, família, por ser meu alicerce e minha principal fonte de amor e paz. Amo-os profundamente.

Ao Prof. Dr. Mario Campos, pela orientação deste trabalho, pelos ensinamentos durante minha vida acadêmica e pela amizade. Obrigado por me mostrar o quão incrível é a Ciência Geologia. Espero que ainda possamos fazer alguns trabalhos de campo!

Ao Prof. Dr. Renato de Moraes, pelas sempre construtivas discussões no corredor (e às vezes com uma cerveja em defesas de tese), pelas indicações e empréstimos de livros e/ou artigos. Obrigado pela paciência e pela infinita prontidão às discussões.

Às minhas amigas e colegas de trabalho Alice (Kenga), Adriana (Bisteka) e Luana (Lua). A Kenga dividiu sala comigo todo o tempo. Passamos por momentos muito engraçados e também tensos naquela sala. Sempre ajudando um ao outro. Incrível conhecer você, espero que seja pra sempre. A Prof. Bisteka foi outra incrível "aquisição" da vida. Agradeço, primeiro pela sua sincera e deliciosa amizade, e claro, por tudo que você me ensinou. Sinceramente, não me lembro, uma vez se quer, de ter entrado em sua sala para pedir ou perguntar algo e você ter negado ou pedido para voltar mais tarde. Obrigado pelos infinitos cafés, e pelos sempre engraçados trabalhos de campo. A Lua. Báaah, tchê! Conheci poucas pessoas com tanta atitude como essa gaúcha. Uma amiga e uma cientista incrível. Obrigado pelos toques em geoquímica, obrigado pelos churrascos na sua casa, obrigado pelos cigarros que fumamos juntos e pelas conversar/discussões. Sem dúvida, assim como essas duas aí de cima, é uma amizade eterna. Falando e gauchada, tem o grande Maurício Liskaborba! Borba, você é genial e foi uma pena quando você foi trabalhar, fez uma falta enorme nos nossos cafés diários!

À Bilóba (Rafaela Gengo), pela amizade e por me acompanhar durante os trabalhos de campo deste projeto. Amigona de graduação que também está na pós. Precisamos ir mais nos covers de Marilyn Manson pra nos divertir!! Valeu!!

Agradeço também ao meu querido amigo, e irmão, Fares Pessoa. É um amigo da graduação que nos deixou para ir para a Peróba, mas tenho certeza que esse ainda volta para a academia. Valeu por, mesmo de longe, trocar ideias tanto geológicas como de qualquer outra coisa! Amigo é amigo, né!!! Falando em amigo, jamais deixaria de agradecer ao Rafa, sempre tão pra cima e engraçado. Sem dúvida um cara fundamental, que sempre me ajudou em momentos de desespero ou desânimo durante o mestrado. Momentos estes, que muitas vezes estive com amigos de fora da Geo na "quinta e breja", como a Camila, a Clarissa, a Mari, o Rodrigo, a Tainá, a Júlia, o Vini, o Bruno e por aí vai.

Agradeço também aos infinitos funcionários da Geo e seus também infinitos laboratórios. À FAPESP pela viabilização deste projeto (Projeto Fapesp 2010/111528) e à CNPq, pela concessão da minha bolsa de mestrado.

Por fim, a todos aqueles que, não por mal, esqueci. 


\section{RESUMO}

Na porção W-SW do lobo Guaxupé, pertencente à Nappe Socorro-Guaxupé, nos arredores da cidade de São José do Rio Pardo, é registrado um evento metamórfico e anatético de fácies granulito, sob condições de desidratação da hornblenda, com $\mathrm{T} \geq 850^{\circ} \mathrm{C}$. As rochas diatexíticas, que compõem as suítes São José do Rio Pardo (SJRP) e Pinhal, resultam desse evento de alta temperatura, ocorrido há 625 Ma. As assinaturas geoquímicas e isotópicas sugerem uma geração a partir da anatexia da crosta continental inferior. Além disso, o enriquecimento em potássio da suíte SJRP indica uma afinidade vaugnerítica, a qual é caracterizada por altos conteúdos de $\mathrm{Mg}$, elementos do tipo LILE (large ion lithophile elements), HFSE (high field strenght elements) e ETR-leves, além de valores negativos de $\varepsilon N d$ e razões de $\mathrm{Sr}$ iniciais baixas, $\sim 0.706$. O magmatismo vaugnerítico implica em um manto litosférico metassomatizado como fonte, o qual foi enriquecido por eventos de subducção precedentes. A presença de pseudomorfos de fusão nesses diatexitos indicam uma evolução quase isotérmica sob presença de líquido anatético. O transporte sin-magmático ocorreu para NE-E. A fonte de calor para esse metamorfismo pode estar associada à delaminação da base do arco magmático.

O processo de fusão parcial gerou leucossomas charno-enderbíticos na Unidade Metatexítica, com assinaturas geoquímicas e isotópicas que indicam uma fonte crustal. Dessas rochas, foram separados cristais de zircão que mostraram duas populações distintas. A primeira, tipicamente com cristais prismáticos e bipiramidados, indicam idades em torno de $620 \mathrm{Ma}$, enquanto que a segunda, com cristais isométricos típicos de alto grau metamórfico, indicam idades em torno de 610 Ma. Em relação ao pico metamórfico de $\sim 625 \mathrm{Ma}$, as idades mais jovens obtidas sugerem um período de 15 my em que predominaram altas temperaturas. 0 transporte tectônico para NW, em estado sólido de alta temperatura, é posterior à cinemática sin-magmática para NE, e deve estar associado à compressão da placa superior convergente, dentro desse período de alta temperatura. Esse regime tectônico é compatível com modelos recentes da tectônica Andina onde é descrita uma subducção horizontal (Pampean flat subduction).

Dentre as rochas da Unidade Granulítica Basal, também submetida à fusão parcial por desidratação da hornblenda, ocorrem gnaisses com afinidade adakítica, sugerida pelas altas razões $\mathrm{Sr} / \mathrm{Y}=72.73, \mathrm{La} / \mathrm{Yb}=23.07,(\mathrm{La} / \mathrm{Yb})_{\mathrm{N}}=15.56$, e teores 
de \#mg = 51.77, Sr = 1062 ppm, $\mathrm{Cr}=197$ ppm e Ni = 103 ppm. Tal afinidade sugere magmas resultantes da fusão de um slab em subducção.

A Nappe Socorro-Guaxupé admite uma evolução que se inicia, cerca de 670$640 \mathrm{Ma}$, com uma subducção inclinada para a geração de rochas cálcio-alcalinas com alguns membros adakíticos. É seguido um momento de colisão, entre 625 e $610 \mathrm{Ma}$, com a geração de rochas diatexíticas e metatexíticas de alto potássio, onde o arco migrou primeiramente para o ante-arco (estado subsólido) e depois em direção ao interior da placa superior (estado sólido). A estabilização da nappe se deu quando da colocação dos maciços sieníticos pós-tectônicos, Capituva e Pedra Branca.

Palavras chave: Nappe Socorro-Guaxupé; fácies granulito; LA-MC-ICPMS U-Pb; Lu-Hf; zircão; orogênese. 


\section{ABSTRACT}

The W-SW portion of the Guaxupé Domain, nearby the São José do Rio Pardo city, records a granulite facies anatetic event under hornblende dehydrationmelting conditions, i.e. $\mathrm{T} \geq 850^{\circ} \mathrm{C}$. The diatexitic rocks that are comprised within the São José do Rio Pardo and Pinhal suites resulted from this high-T metamorphic event, ca. $625 \mathrm{Ma}$. Geochemical and isotopic signatures suggest derivation from the lower continental crust. The K-rich SJRP suite also show geochemical affinity with vaugneritic rocks, suggested by high contents of Mg, LILE, HFSE and light-REE in addition to negative $\varepsilon N d$ and low $\mathrm{Sr}$ initial ratio $(\sim 0.706)$. Vaugneritic magmatism implies on a derivation from a metasomatized lithospheric mantle source enriched before partial melting in a previous subduction setting. Once both suites contain melt pseudomorphs, it is then suggested and isothermic evolution under the presence of melt. A syn-magmatic driven transport occurred towards NE-E, and the heat source for high-T conditions could be assigned to mantle delamination under the margmatic arc.

Within the Metatexitic Unit, partial melting resulted in charno-enderbitic leucosomes whose geochemical and isotopic signatures indicate crustal sources. From these leucosomes, two different populations of zircon crystals were separated. The first, comprising bypiramidal-prismatic grains, yield ages around $620 \mathrm{Ma}$, whereas the second typology of zircons is isometric and soccer-ball type, yielding younger ages around $610 \mathrm{Ma}$. The latter typology is typical of high-T and meltbearing rocks. Considering the $625 \mathrm{Ma}$ metamorphic peak, the younger ages suggest a 15 my period when high-T conditions prevailed. Top-to-NW transport, under solidstate high-T conditions, can be associated to the compression of the upper convergent plate within this high-T period. Textural features suggest this transport to have occurred after the crystallization of the syn-magmatic rocks. The compression of the upper plate resembles recent models of the Andean orogenic cycle, where the Pampean flat subduction is described.

Among the rocks of the Basal Granulitc Unit, which also underwent hornblende-dehydration partial melting, a gneissic rock shows adakitic affinity, suggested by $\mathrm{Sr} / \mathrm{Y}=72.73, \mathrm{La} / \mathrm{Yb}=23.07,(\mathrm{La} / \mathrm{Yb})_{\mathrm{N}}=15.56, \mathrm{\# mg}=51.77, \mathrm{Sr}=1062$ ppm, $\mathrm{Cr}=197 \mathrm{ppm}$ and $\mathrm{Ni}=103$ ppm. Adakitic magmas are thought to be slab melts. 
The Socorro-Guaxupé Nappe was built up between 670 and 640 Ma with a steep subduction and generation of calc-alkaline and subordinate adakitic rocks. A collisional setting, generating high- $\mathrm{K}$ diatexites and metatexites, took place between 625 and $610 \mathrm{Ma}$, where the arc firstly migrated (in subsolidus state) towards the forearc and then migrated (in solid state) towards the interior of the upper plate. Posttectonic Capituva and Pedra Branca syenitic plutons intruded around $610 \mathrm{Ma}$, recording the arc migration ceasing.

Key-words: Socorro-Guaxupé Nappe; granulites facies; LA-MC-ICPMS U-Pb; Lu-Hf; zircon; orogenesis. 


\section{SUMÁRIO}

CAPÍTULO 1: INTRODUÇÃO

1.1 Apresentação da temática abordada 1

1.2 Objetivos 3

1.3 Estrutura da tese 3

CAPÍTULO 2: MATERIAIS E MÉTODOS 4

2.1 Revisão Bibliográfica 4

2.2 Trabalhos de campo 4

2.3 Integração de mapas geológicos 4

2.4 Petrografia macro e microscópica 5

2.5 Análise estrutural 5

2.6 Geoquímica elemental 5

2.7 Geoquímica isotópica ___ 6

2.8 Geocronologia U-Pb e análises Lu-Hf __ 6

CAPÍTULO 3: LOCALIZAÇÃO E ACESSOS __ 8

CAPÍTULO 4: BREVE SÍNTESE SOBRE ANATEXIA _ 10

4.1 o processo de fusão parcial e a relação entre migmatitos e granitos _ 10

4.2 Microestruturas de fusão versus pseudomorfos de fusão 12

4.2.1 Tamanho dos poros e topologia do fundido 13

CAPÍTULO 5: CONTEXTO GEOLÓGICO 16

5.1 A porção marginal sul do Cráton Sanfranciscano _ـ 16

5.2 A Nappe Socorro-Guaxupé (NSG) _ـ 18

5.3 A porção W-SW do Domínio Guaxupé ___ 21

CAPÍTULO 6: DESCRIÇÃO DAS UNIDADE LITOLÓGICA __ 24

6.1 Unidade Granulítica Basal __ 24

6.2 Unidade Diatexítica ___ 28

6.2.1 Suíte Granito-Migmatítica Pinhal ___ 28

6.2.2 Suíte Granito-Charnockítica S. José do Rio Pardo ___ 34

6.3 Unidade Metatexítica __ 45

6.3.1 Seqüência Metassedimentar _ـ 45

6.3.2 Gnaisses Migmatíticos _ 46

CAPÍTULO 7: GEOLOGIA ESTRUTURAL _ $\mathbf{5 0}$

7.1 A foliação $S_{1}$ e os dobramentos posteriores

7.2 As lineações minerais e o transporte tectônico___ 52 
CAPÍTULO 8: GEOQUÍMICA DOS ELEMENTOS MAIORES, TRAÇOS E TERRAS

RARAS 57

8.1 Elementos maiores 58

8.2 Elementos traços 63

8.2.1 Elementos terras rara (ETR) 65

CAPÍTULO 9: GEOCRONOLOGIA E GEOQUÍMICA ISOTÓPICA 69

9.1 Unidade Granulítica Basal 69

9.2 Unidade Diatexítica 71

9.3 Unidade Metatexítica 73

CAPÍTULO 10: INTEGRAÇÃO DOS DADOS E DISCUSSÕES 87

10.1 Metamorfismo e microestruturas de fusão 87

10.2 Idade do metamorfismo 96

10.3 Transporte tectônico e deformação: W-SW do lobo Guaxupé 98

10.4 Considerações finais e implicações tectônicas 99

CAPÍTULO 11: CONCLUSÕES 102 REFERÊNCIAS BIBLIOGRÁFICAS 104

ANEXO I - MAPA GEOLÓGICO 115

ANEXO II - MAPA DE PONTOS 116

\section{ÍNDICE DE FIGURAS}

Figura 3: Localização da área de estudo 4

Figura 4: Esquema sequencial mostrando o início da fusãoparcial nas junções tríplices, seguindo com a interconexão do fundido 13

Figura 4.1: Ilustração esquemática da topologia do fundido com diferentes ângulos dihedrais 15

Figura 5: Quadro tectônico do Orógeno Brasília Meridional 17

Figura 6: Fotos mesoscópicas da Unidade Granulítica Basal 25

Prancha I: Fotomicrografias da Unidade Granulítica Basal 27

Figura 6.1: Fotos mesoscópicas da Suíte Pinhal 29

Figura 6.2: Fotos mesoscópicas com estruturas da Unidade Diatexítica 33

Figura 6.3: Fotos mesoscópicas da suíte São José do Rio Pardo 37

Figura 6.4: Fotos mesoscópicas com relações migmatíticas da suíte São José do Rio Pardo 40

Prancha II: Fotomicrografias da suíte Pinhal 42 
Prancha III: Fotomicrografias da suíte São José do Rio Pardo 43

Prancha Illa: Fotomicrografias da suíte São José do Rio Pardo 44

Figura 6.5: Fotos mesoscópicas da Unidade Metatexítica 46

Prancha IV: Fotomicrografias da Unidade Metatexítica 49

Figura 7: Projeção estereográfica dos pólos da foliação $S_{1}$ 51

Figura 7.1: Projeção estereográfica das diferentes lineações minerais 53

Figura 7.2: Feições estruturais em escala de afloramento 56

Figura 8: Diagramas de Harker com elementos maiores vs. sílica 59

Figura 8.1: Diagramas de classificação geoquímica 61

Figura 8.2: Diagrama binário com elementos compatíveis vs. elementos incompatíveis 62

Figura 8.3: Diagramas de Harker com elementos traço vs. sílica 64

Figura 8.4: Padrão de elementos terras raras normalizados para valores condríticos (Bayton, 1984) 66

Figura 9: Diagrama concórdia com idades U-Pb em zircão para granulitos intermediários da Unidade Granulítica Basal obtidos por Basei et al. (inédito) 69

Figura 9.1: Unidade Granulítica Basal - (A) Valores de $\varepsilon N d$ com idades modelo; (B) Diagrama $\varepsilon \mathrm{Nd}_{(640)}$ vs. ${ }^{87} \mathrm{Sr} /{ }^{86} \mathrm{Sr}$ 70

Figura 9.2: Diagrama concórdia com idades U-Pb em zircão para a suíte São José do Rio Pardo obtidos por Basei et al. (inédito) 71

Figura 9.3: Suíte São José do Rio Pardo - (A) Valores de $\varepsilon N d$ com idades modelo; (B) Diagrama $\varepsilon \mathrm{Nd}_{(628)}$ vs. ${ }^{87} \mathrm{Sr} /{ }^{86} \mathrm{Sr}$ 72

Figura 9.4: Suíte Pinhal - (A) Valores de $\varepsilon N d$ com idades modelo; (B) Diagrama $\varepsilon \mathrm{Nd}_{(625)}$ vs. ${ }^{87} \mathrm{Sr} /{ }^{86} \mathrm{Sr}$ 73

Figura 9.5: Imagens de catodoluminescência e tipologia dos zircões da amostra Gx77A2 (leucossoma) 74

Figura 9.6: (A) Diagrama concórdia com idades U-Pb em zircões prismáticos do leucossoma da Unidade Metatexítica; (B) Diagrama concórdia com idades U-Pb em zircões isométricos do mesmo leucossoma 75

Figura 9.7: Imagens de catodoluminescência e tipologia dos zircões da amostra Gx77B1 (paleossoma) 76

Figura 9.8: (A) Diagrama concórdia com idades U-Pb em zircões do paleossoma; (B) Histograma com idades ${ }^{206} \mathrm{~Pb} /{ }^{238} \mathrm{U}$ para o mesmo conjunto de zircões 77

Figura 9.9: Diagrama com razões $\mathrm{Th} / \mathrm{U}$ vs. idade $\mathrm{U}-\mathrm{Pb}$ pontual 77 
Figura 9.10: Unidade Metatexítica - (A) Valores de $\varepsilon N d$ com idades modelo; (B) Diagrama $\varepsilon \mathrm{Nd}_{(608)}$ vs. ${ }^{87} \mathrm{Sr} /{ }^{86} \mathrm{Sr}$

Figura 9.11: Valores de $\varepsilon \mathrm{Hf}$ calculados para as idades pontuais $\mathrm{U}-\mathrm{Pb}$ e valores das idades modelo $\mathrm{T}_{\mathrm{DM}(\mathrm{Hf})}$ por duplo-estágio

Figura 10: Grade petrogenética com o campo de estabilidade e possível trajetória metamórfica das rochas estudadas

Figura 10.1: Padrão de elementos terras raras normalizados para o possível paleossoma (Gx-76C) 89

Figura 10.2: Padrão de elementos terras raras normalizados para o possível paleossoma (Gx-22C) 92

\section{ÍNDICE DE TABELAS}

Tabela 8: Amostras analisadas neste projeto com sua associação litológica e indicação de geoquímica elemental

Tabela 8.1: Resultados das análises químicas por FRX e parâmetros geoquímicos. Elementos maiores em \% e elementos menores e traços em ppm

Tabela 8.2: Resultados de análises químicas por ICP-MS para elementos traços e terras raras 68

Tabela 9: Dados isotópicos $\mathrm{Sm}-\mathrm{Nd}$ e $\mathrm{Rb}-\mathrm{Sr}$ das rochas da porção sul-ocidental do lobo Guaxupé

Tabela 9.1: Resultados das análises U-Pb para os zircões prismáticos do leucossoma 82

Tabela 9.2: Resultados da análises U-Pb para os zircões isométricos do leucossoma 83

Tabela 9.3: Resultados das análises $\mathrm{U}-\mathrm{Pb}$ para as bordas dos zircões do paleossoma

Tabela 9.4: Resultados das análises U-Pb para os núcleos dos zircões do paleossoma

Tabela 9.6: Resultados da análises Lu-Hf pontuais nos zircões do leucossoma e paleossoma da Unidade Metatexítica 86 


\section{CAPÍTULO 1}

\section{INTRODUÇÃO}

\subsection{Apresentação da temática abordada}

Orógenos acrecionários, de margem continental ativa, do tipo Andino (altiplano ou cordilherano), caracterizam-se pela compressão da litosfera da placa superior. O controle desta compressão está na cinemática de placas: a velocidade da placa superior é maior ou igual, e na mesma direção que a velocidade de retração (de roll-back) do slab em subducção (Pluijm \& Marshak, 2004). A delaminação da litosfera do arco (Shurr et al., 2006), ou sua remoção por subducção ablativa (Pope \& Willett, 1998) é a interação manto-crosta mais aceita para o incremento da velocidade da placa superior. A crosta siálica espessada é seguida pelo aumento do fluxo de calor, diminuição da viscosidade e "enfraquecimento" mecânico durante o encurtamento tectônico (Sobolev \& Babeyko, 2005). Neste processo o encurtamento é acomodado, na superfície e em domínio de retro-arco, por um cinturão de cavalgamento e dobramento (fold and thrust belt). Em níveis de crosta profunda ocorre a duplicação entre a crosta inferior e a crosta superior, desde a infraestrutura do arco (Moores \& Twiss, 1999; Jaillard et al., 2000). A intensa deformação, dominada por nappes em profundidade, é, cinematicamente dirigida para o interior da placa superior, no mesmo sentido da litosfera da placa inferior em subducção (Şengör, 1990 e 1991; Cook \& Varsek, 1994; Sizova et al., 2010).

Estudos geofísicos, principalmente na orogenia Andina, mostram a influência da flutuação positiva da placa em subducção. Esse comportamento gera a horizontalização da placa em subducção, como descrito no Papean flat slab (e.g. Gutcher et al., 2000a; Ramos et al, 2002; Orts et al, 2012), nos Andes Centrais, o que acaba por direcionar o domínio de arco em direção ao interior da placa superior.

Em oposição, arcos magmáticos neutros, com extensão no retro-arco e contração no ante-arco, dirige toda a crosta siálica do arco sensu-stricto sobre o domínio de ante-arco, configurando nappes transportadas no sentido oposto à subducção e cinturões metamórficos pareados (Isozaki et al., 2010).

No domínio paleogeográfico do arco é característico um metamorfismo de alta temperatura e relativamente baixa pressão, típico de isotermas relaxadas onde, em 
profundidades relativamente rasas, a crosta superior começa a fundir em presença de água, ou da rehidratação (de crosta profunda exumada). Uma profusa fusão parcial ocorre em profundidade, com múltiplas perdas de líquidos anatéticos para granitos (que registram o estrato de crosta em que foram gerados) em plutons ou camadas in situ e que produzem ou consomem reações em xenólitos pelíticos residuais (Janasi,1999; Korhonen et al., 2010, Kriegsman \& Álvarez-Valero, 2010; Maruyama et al, 2010, Sawyer, 2010). A geração de líquidos anatéticos durante a orogênese pode ser muito bem documentada em fases minerais acessórias como 0 zircão. Os cristais de zircão podem ser os únicos minerais a manter seu sistema fechado durante o aumento da temperatura, podendo recristalizar, residir no pico termal ou até mesmo cristalizar em alta temperatura (Tichomirowa et al., 2005; Harley et al., 2007).

O aumento do fluxo de calor faz com que o volume de fundido contido nas rochas aumente. A presença de fundido modifica o comportamento reológico das rochas em pelo menos dois estágios. A primeira transição reológica ocorre com menos de $10 \%$ em volume de fundido, quando o enfraquecimento da rocha cresce de forma exponencial e corresponde ao momento de interconexão dos filmes de líquido anatético através da rocha. Esse comportamento é, provavelmente, responsável pelo desenvolvimento de grandes zonas de descolamento em ambientes colisionais (Jamieson et al., 2011). A segunda transição reológica importante ocorre entre $20-60 \%$ em volume de fundido, intervalo que representa a perda do estado sólido da rocha. Em orógenos colisionais, entretanto, esse comportamento não deve ser atingido na área de produção de líquido anatético, e sim em níveis crustais mais rasos onde o melt é coletado (Brown, 2007).

No sudeste brasileiro a Nappe Socorro-Guaxupé, neoproterozóico da faixa marginal sul do Cráton do São Francisco, extremo meridional do Orógeno Brasília (sínteses em Campos Neto, 2000 e Heilbron et al., 2004) é considerada uma espessa raiz de arco magmático. Suas unidades tectônicas inferiores registram um metamorfismo com características de isotermas relaxadas (Campos Neto e Caby, 2000), enquanto que as unidades tectônicas superiores registram um metamorfismo com características de espessamento de crosta sin-colisão (Martins et al, 2010).

A Nappe Socorro-Guaxupé cavalga, horizontalmente e em profundidade (Campos Neto et al., 2004), unidades que podem estar relacionadas à paleogeografia de ante-arco (Campos Neto et al., 2011). Em sua retaguarda, rochas graníticas e diatexíticas, suítes mangeríticas e metatexitos (com pouca preservação 
do protolito ígneo ou sedimentar) associados a granulitos, dominam. Essas rochas registram intensa deformação não-coaxial, em uma foliação tectônica primária associada a intensa lineação mineral ou de estiramento mineral, orientada noroeste (Campos Neto et al., 1988).

\subsection{Objetivos}

Em primeiro lugar, este trabalho objetivou estabelecer a geometria e a cinemática da lineação de estiramento mineral associada à foliação metamórfica principal do lobo norte da Nappe Socorro-Guaxupé. Além disso, buscou-se estimar as condições térmicas quando da geração de cada tipo de lineação, orientação do fluxo e idade do processo de anatexia.

No contexto mais geral essa pesquisa buscou, na Nappe Socorro-Guaxupé, as características estruturais e termo-mecânicas de um orógeno acrecionário neutro ou andino.

\subsection{Estrutura da tese}

Nos primeiros cinco capítulos, buscou-se apresentar temas introdutórios, como alguns tipos de orógenos acrescionários, a localização e os acessos à área de estudo e os materiais e métodos. No Capítulo 4, apresenta-se uma breve revisão sobre anatexia, focando principalmente nas microestruturas geradas na rochas, 0 que é utilizado nas descrições e discussões dos capítulos seguintes. No Capítulo 5, é feita uma revisão sobre o contexto geológico desde a escala regional até a local. Do Capítulo 6 ao 9, são apresentados os resultados inéditos obtidos nesta dissertação e as tabelas de resultados analíticos estão no final do seu respectivo capítulo. Os capítulos 10 e 11, respectivamente, apresentam discussões e conclusões. Segue-se com a lista de todas as referências citadas no texto, e, finalmente, o Anexo I e II consiste no mapa litoestrutural da área de estudo e mapa de pontos, respectivamente. 


\section{CAPÍTULO 2}

\section{MATERIAIS E MÉTODOS}

\subsection{Revisão bibliográfica}

A primeira etapa desenvolvida neste trabalho foi o levantamento bibliográfico com o objetivo de fundamentar temas, tais como: contexto geológico regional e local, modelos geodinâmicos de orógenos acrescionários, processo de fusão parcial em macro e microescala, litogeoquímica e geocronologia in situ em cristais de zircão. Foi feita a partir de livros-texto, relatórios de cartografias geológicas e artigos científicos.

\subsection{Trabalho de campo}

Os trabalhos de campo, feitos no primeiro ano do presente projeto, foram baseados nas folhas topográficas Guaranésia (SF-23-V-C-III-3), Guaxupé (SF-23-VC-III-4), São José do Rio Pardo (SF-23-V-C-VI-1), e Caconde (SF-23-V-C-VI-2), todas na escala 1:50.000 do IBGE (1970). Com a etapa de campo, foi possível reconhecer as principais unidades litológicas, coletar dados estruturais e amostras para descrições petrográficas, análises geoquímicas e determinações geocronológicas.

\subsection{Integração de mapas geológicos}

A fim de cobrir a área de estudo e verificar a continuidade das unidades litológicas principais e estruturas associadas, realizou-se a integração dos mapas geológicos disponíveis na literatura, a citar: folhas São José do Rio Pardo (SF-23-VC-VI-I) e Guaranésia (SC-23-V-C-III-3), em escala 1:50.000, de Campos Neto et al. (1985) e folha Caconde (SF-23-V-C-VI-2-NO), em escala 1:25.000, de Oliveira et al. (1989). A integração resultou em um mapa 1:250.000 desenhado no ArcGis Desktop 9.3 e 10 . 


\subsection{Petrografia macro e microscópica}

A petrografia macroscópica incluiu a descrição de 58 afloramentos para a identificação da mineralogia, texturas e estruturas. Foi coletado um total de 84 amostras, quando possível, orientadas segundo sua estrutura. Para o estudo microscópico, foram descritas 60 lâminas delgadas, quando possível orientadas, a fim de observar as principais fases minerais e paragêneses, forma de ocorrência, hábito e dimensões dos cristais, além de detalhada descrição de texturas e microestruturas. Para tanto, foram utilizados os microscópios petrográficos ZEISS (Axioplan) e Olympus BXP-50 do Laboratório de Microscopia Petrográfica (LMP) e Olympus BXP-40 do Laboratório Didático de Microscopia Petrográfica do Instituto de Geociências da Universidade de São Paulo (IGc-USP).

\subsection{Análise Estrutural}

A análise estrutural foi feita a partir da interpretação do arranjo estrutural descrito em meso- e microescala (foliação, lineação e indicadores cinemáticos). Os dados foram plotados no mapa geológico e tratados em estereogramas a partir do software OpenStereo 0.1.2 (Grohmann \& Campanha, 2010). Visualizações em 3D e rotações estereográficas foram feitas a partir do estereograma on-line disponível em http://app.visiblegeology.com.

\subsection{Geoquímica Elemental}

Foram selecionadas 11 amostras para análises geoquímicas, as quais estão discriminadas na Tabela 8.

A preparação das amostras para análise laboratorial foi feita no Laboratório de Tratamento de Amostras (LTA) do IGc-USP, de acordo com os seguintes passos: (i) cominuição em prensa hidráulica para obter fragmentos menores do que $1 \mathrm{~cm}$; (ii) quarteamento para retirada de aproximadamente $100 \mathrm{~g}$ representativos de cada amostra; (iii) moagem em moinho de ágata do tipo planetário até obtenção de pó com granulação inferior a 200 mesh.

Para todas as amostras, foram analisados os elementos maiores, menores e alguns traços no Laboratório de Espectrometria e Fluorescência de Raios-X (FRX) 
do IGc-USP, por meio do equipamento automático Philips, modelo PW24000. A metodologia utilizada está descrita em Mori et al. (1999).

Oito amostras foram escolhidas para análises de elementos traço e elementos terras raras por meio de espectrometria de massa com plasma induzido acoplado (ICP-MS). Tais análises foram feitas no Laboratório de Química e ICPAES/MS do IGc-USP, utilizando o espectrômetro do tipo quadrupolo, modelo ELAN 6100DRC da PerkinElmer/Sciex. A metodologia segue o descrito em Navarro et al. (2008).

O tratamento de dados e a geração de diagramas binários e de classificação foram realizados no programa GCDKit (Geochemical Data Toolkit in R, versão 3.0 para Windows), de Janoušek et al. (2006).

\subsection{Geoquímica Isotópica}

Foram escolhidas oito amostras (Tabela 9) para análises de geoquímica isotópica $\mathrm{Rb}-\mathrm{Sr}$ e Sm-Nd em sistema rocha total. As análises foram feitas no Centro de Pesquisas Geocronológicas (CPGeo) do IGc-USP, via TIMS (Thermal Ionization Mass Spectromerty), utilizando-se de um espectrômetro VG354 e um detector Faraday único. A metodologia $\mathrm{Rb}-\mathrm{Sr}$ segue o trabalho de Torquato \& Kawashita (1994) e a metodologia Sm-Nd segue Sato et al. (1995), ambas revisadas no trabalho de Souza (2009).

As razões elementais $\mathrm{Rb} / \mathrm{Sr}$ e $\mathrm{Sm} / \mathrm{Nd}$ foram obtidas, respectivamente, por fluorescência de raios-X e ICP-MS. As razões normalizadas são ${ }^{86} \mathrm{Sr} /{ }^{88} \mathrm{Sr}=0.1194 \mathrm{e}$ ${ }^{146} \mathrm{Nd} /{ }^{144} \mathrm{Nd}=0.7219$ e as constantes utilizadas são conforme Steiger \& Jäeger (1978) para Sr e De Paolo (1981) para Nd.

\subsection{Geocronologia U-Pb e análises pontuais Lu-Hf}

Duas amostras, um leucossoma (Gx-77A2) e um paleossoma (Gx-77B1), foram escolhidos para análises isotópicas pontuais em cristais de zircão. Tais análises envolveram determinações U-Pb (Basei et al., 1995) e Lu-Hf (Belousova et al. 2006; Kinny \& Maas, 2003).

O processo de preparação das amostras para obtenção dos cristais de zircão se deu no laboratório de separação do CPGeo do IGc-USP, sob orientação dos 
técnicos Vasco Antonio P. Loios e Maurício Dias de Souza. Fazem parte do processo, as seguintes etapas:

(a) Fragmentação das amostras com marreta para obtenção de alíquotas, aproximadamente, menores do que $3 \mathrm{~cm}$;

(b) Cominuição em britador primário de mandíbulas de aço para atingir alíquotas menores do que $1 \mathrm{~cm}$;

(c) Moagem em moinho de disco de tungstênio e peneiramento para a separação de frações com granulação entre 100 e $200 \mu \mathrm{m}$ e frações menores do que $200 \mu \mathrm{m}$;

(d) Concentração de minerais densos por pressão de água e vibração em mesa de concentração Wiffley;

(e) Separação dos minerais magnéticos com ímã de mão;

(f) Nova separação de minerais magnéticos, agora utilizando o separador magnético do tipo Frantz, sob amperagem de $0.5 \mathrm{~A}$;

(g) A porção com minerais não magnéticos é levada à capela de exaustão e colocada em bromofrórmio $\left(\mathrm{CHBr}_{3}\right)$, cuja densidade é de $2,89 \mathrm{~g} / \mathrm{cm}^{3}$. Separam-se então os minerais mais densos do que $2,89 \mathrm{~g} / \mathrm{cm}^{3}$;

(h) A alíquota de minerais mais densos que o bromofórmio é levada ao Frantz para uma separação sob amperagem de $0.5 \mathrm{~A}$;

(i) A porção não magnética resultante, é levada à capela de exaustão e colocada em iodeto de metileno $\left(\mathrm{CH}_{2} \mathrm{I}_{2}\right)$, cuja densidade é $3,32 \mathrm{~g} / \mathrm{cm}^{3}$;

(j) O concentrado mais denso que o iodeto de metileno é analisado em uma lupa Leika para verificar a existência de zircão;

(k) O concentrado final é encaminhado para a catação manual e posterior montagem de mounts com resina epoxy.

Quando os concentrados estão preparados na resina, realiza-se o polimento da resina até que as faces dos cristais de zircão a serem analizados sejam atingidas. As seções polidas são levadas a um Microscópio Eletrônico de Varredura (MEV) a fim de se obterem imagens de elétrons secundários e imagens de catodoluminescência.

Com o auxílio das imagens, é possível posicionar o feixe de laser durante as análises no LA-MC-ICP (Laser Ablation Multi-collector Inductively Coupled Plasma Mass Spectrometry). As condições analíticas para U-Pb são $5 \mathrm{~mJ}, 6 \mathrm{~Hz}$ e diâmetro de feixe de $29 \mu \mathrm{m}$. Para as análises Lu-Hf, $6 \mathrm{~mJ}, 7 \mathrm{~Hz}$ e diâmetro de feixe de $48 \mu \mathrm{m}$. 


\section{CAPÍTULO 3}

\section{LOCALIZAÇÃO E ACESSOS}

A área de estudo se situa no nordeste do Estado de São Paulo junto à divisa com o Estado de Minas Gerais, no sudeste brasileiro (Figura 3). No Estado de São Paulo, abrange os municípios de São Sebastião da Grama, São José do Rio Pardo, Caconde, Mococa e Tapiratiba, e no Estado de Minas Gerais, os municípios de Guaranésia e Guaxupé. Grande parte do trabalho de campo foi feito do Estado de São Paulo, dentro da área destaca por um polígono cinza na Figura 3. A porção destacada refere-se também aos mapas geológicos 1:50.000 disponíveis na literatura e que foram, nesta tese, integrados em um mapa geológico de apoio na escala 1:250.000 (Anexo I). As folhas topográficas utilizadas como base foram: Guaranésia (SF-23-V-C-III-3), Guaxupé (SF-23-V-C-III-4), São José do Rio Pardo (SF-23-V-C-VI-1), e Caconde (SF-23-V-C-VI-2), todas na escala 1:50.000 do IBGE (1970).

O acesso à área de estudo, a partir da cidade de São Paulo, é feito pela Rodovia dos Bandeirantes até a altura da cidade de Campinas, de onde se toma a Rodovida Dom Pedro I para acessar a Rodovia SP-340. Nesta, segue-se até a cidade de Aguaí, quando é possível tomar a Rodovia SP-344, que passa por São João da Boa vista e Vargem Grande do Sul até chegar a São Sebastião da Grama. 


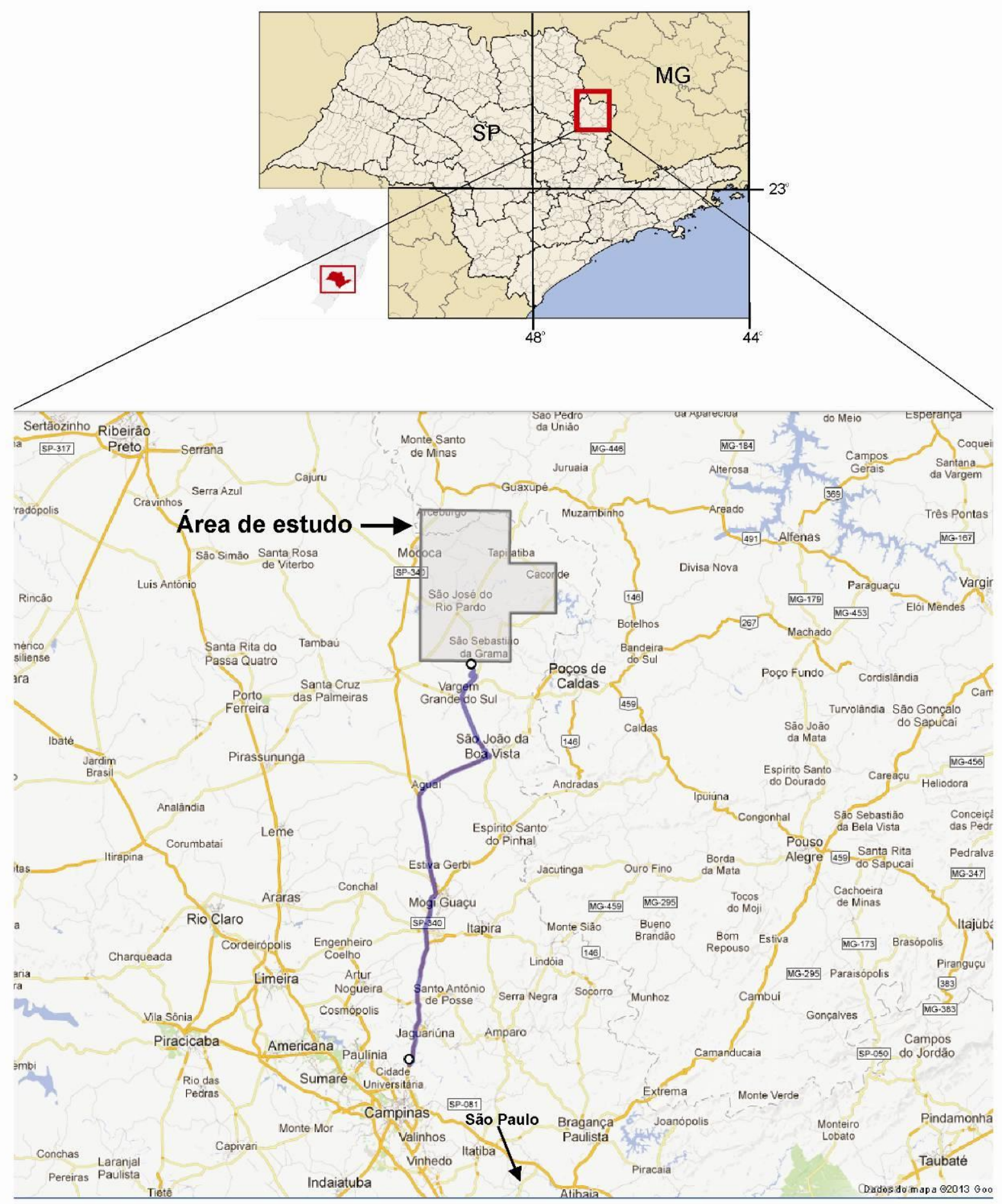

Figura 3 - Localização da área de estudo. Em cima, o quadrado vermelho localiza a área entre os Estados de São Paulo e Minas Gerais. Abaixo, uma imagem de maior detalhe colocando os municípios e as rodovias que dão acesso e atravessam a área de estudo. O polígono cinza indica a área de estudo onde foi feita a integração dos mapas geológicos disponíveis na literatura. A linha azul, no centro, traça o caminho a partir da cidade de Campinas. 


\section{CAPÍTULO 4}

\section{BREVE REVISÃO SOBRE ANATEXIA}

\subsection{O processo de fusão parcial e a relação entre migmatitos e granitos}

Enquanto as rochas ígneas apresentam microestruturas (e/ou texturas) que refletem processos de cristalização magmática, as rochas migmatíticas podem preservar microestruturas que estão diretamente relacionadas ao processo de fusão parcial (ou anatexia). Tal processo é assunto de grandes discussões para a geração dos granitos e influenciou muito no desenvolvimento das teorias de origem dos migmatitos. De início, Bowen (1928) havia demonstrado que magmas graníticos poderiam ser formados a partir da extrema cristalização fracionada de magmas basálticos. Entretanto, observou-se que a quantidade de granitos em relação a sua fonte basáltica era enorme, surgindo a atuação de processos adicionais na geração de magmas graníticos (Sawyer, 2008). Com isso, os estudos da fusão parcial tomaram força e observou-se que grandes batólitos graníticos poderiam ter sido gerados com a anatexia da base da crosta continental, onde uma grande quantidade de fundido foi extraída por longas distâncias em direção a níveis crustais mais rasos. Por outro lado, em terrenos metamórficos de alto grau, sujeitos ao metamorfismo regional, ocorrem rochas gnáissicas e metapelíticas com porções graníticas associadas. Sem a presença de corpos graníticos importantes pelos arredores, interpretou-se que tais porções eram resultado da chamada fusão parcial in situ (Holmquist, 1916).

O magmatismo granítico é um dos principais processos de reciclagem da crosta continental, principalmente durante eventos orogênicos, resultando na diferenciação geoquímica da crosta que ocorre desde o Arqueano (Brown, 2001). Dependendo da fertilidade do protólito, da atividade de fases voláteis ricas em água, da taxa de aquecimento, do tipo de deformação e da máxima temperatura atingida, as rochas começam a fundir e evoluem desde metatexitos com baixa taxa de fusão até diatexitos com altas taxas de fusão.

Caso um protólito fértil seja submetido à anatexia sob condições tectônicas de cisalhamento simples, onde são criados gradientes de pressão, então é possível que uma grande quantidade de fundido seja extraída de sua fonte. A partir dessa 
extração, processos ígneos podem afetar o líquido granítico até que ele seja coletado, em níveis crustais mais rasos, para formar grandes batólitos graníticos evoluídos, deixando para trás rochas granulíticas residuais. Por outro lado, um volume menor de fundido, mesmo sob condições dinâmicas, pode não adquirir tanta mobilidade e tampouco é capaz de alimentar grandes batólitos, impedindo uma extração de líquido efetiva e gerando terrenos migmatíticos.

Os terrenos migmatíticos mais comuns são aqueles formados em orógenos submetidos ao metamorfismo regional e que apresentam um longo e lento caminho de resfriamento. Jones \& Brown (1990) propõe uma trajetória P-T horária que atinge a curva de liquidus a altas temperaturas e é seguida de uma descompressão quase isotérmica. Thompson \& Connolly (1995) afirmam que as temperaturas máximas atingidas devido ao espessamento crustal em orógenos colisionais não excedem $750^{\circ}-800^{\circ} \mathrm{C}$. Essas condições de temperatura coincidem com aquelas necessárias para a anatexia devido à quebra da muscovita, a qual, em geral, produz volumes pequenos de magma ( 10\%). A quebra da biotita, geralmente acima de $900^{\circ} \mathrm{C}$, produz volumes maiores de magma, cerca de 30-50\%, dependendo da composição global do protólito. Entretanto, para se atingir essa temperatura, seria necessária uma outra fonte de calor que não a resultante do espessamento crustal, como por exemplo, proveniente do manto. Segundo Thompson (1999), as principais fontes de calor para a anatexia originam-se da (i) descompressão de crostas espessadas, (ii) ascenção do manto astenosféricos sob a crosta de orógenos extensionais e (iii) uma grande intrusão de magmas máficos oriundos do manto nas crosta inferior (underplating).

Vernon \& Clarke (2008) afirmam que o processo de fusão parcial durante o metamorfismo de alto grau ocorre segundo reações de fusão saturadas ou insaturadas em água. As primeiras, cuja contribuição de água provém da quebra de minerais como muscovita, biotita e hornblenda, ocorrem a temperaturas relativamente baixas, entre $630^{\circ}-650^{\circ} \mathrm{C}$. Já as reações insaturadas em água, segundo alguns autores (e.g. Clemens \& Watkins, 2001; Vigneresse, 2004; Clemens, 2005), são muito comuns e ocorrem sob condições do fácies granulito, com temperaturas entre $800^{\circ}-1000^{\circ} \mathrm{C}$. 


\subsection{Microestruturas de fusão versus pseudomorfos de fusão}

O estudo das microestruturas de fusão parcial é feito a partir de feições texturais, associações minerais e reações metamórficas geradoras de líquido anatético (Sawyer 1999). Devem-se levar em conta as diferentes partes que compõem um migmatito, uma vez que os paleossomas tendem a preservar microestruturas diretamente ligadas ao início da fusão parcial, enquanto que neossomas podem preservar aquelas ligadas à cristalização do fundido (Sawyer 2008).

O processo de anatexia inicia-se nas junções tríplices onde todos os minerais reagentes estão em contato e, com o incremento da taxa de fusão, formam-se pequenos bolsões de fundido que podem migrar pelas bordas dos grãos e formar uma rede interconectada (Figura 4). Salvo em auréolas de metamorfismo de contato ou xenólitos fundidos, são muito raros os ambientes geológicos que permitem a preservação - geralmente como vidro - dos primeiros líquidos anatéticos. Grande parte dos migmatitos tem sua origem ligada ao metamorfismo regional em condições lentas de resfriamento (o que permite a cristalização do fundido) sob as influências da deformação, recristalização e retrometamorfismo, o que pode obliterar as feições de fusão parcial sensu strictu.

Dessa forma, o estudo das típicas texturas de fusão parcial é feito a partir de experimentos laboratoriais e sua comparação com migmatitos de auréolas de contato rasas a pouco profundas (Holness et al. 2011). As principais microestruturas que ocorrem tanto em experimentos como em migmatitos rasos são: bolsões triangulares ou tetraédricos convexos de fundido com terminações em cúspide nas junções tríplices (Figura 4.C); filmes estreitos e em cúspide de fundido penetrando a rocha não fundida; minerais reagentes corroídos ou arredondados em um bolsão de líquido (Figura 4.D); e fraturas preenchidas por líquido anatético (Sawyer 2008). Essas estruturas geralmente estão preservadas como vidro e são consideradas como representantes diretas dos primeiros líquidos anatéticos formados pela fusão parcial.

Durante o longo período de resfriamento, os anatexitos regionais evoluem com líquidos anatéticos que preenchem poros e cristalizam. A distribuição do líquido anatético em escala microscópica é inferida através de grãos com fortes terminações em cúspide e baixos ângulos dihedrais (Holness \& Sawyer 2008). 

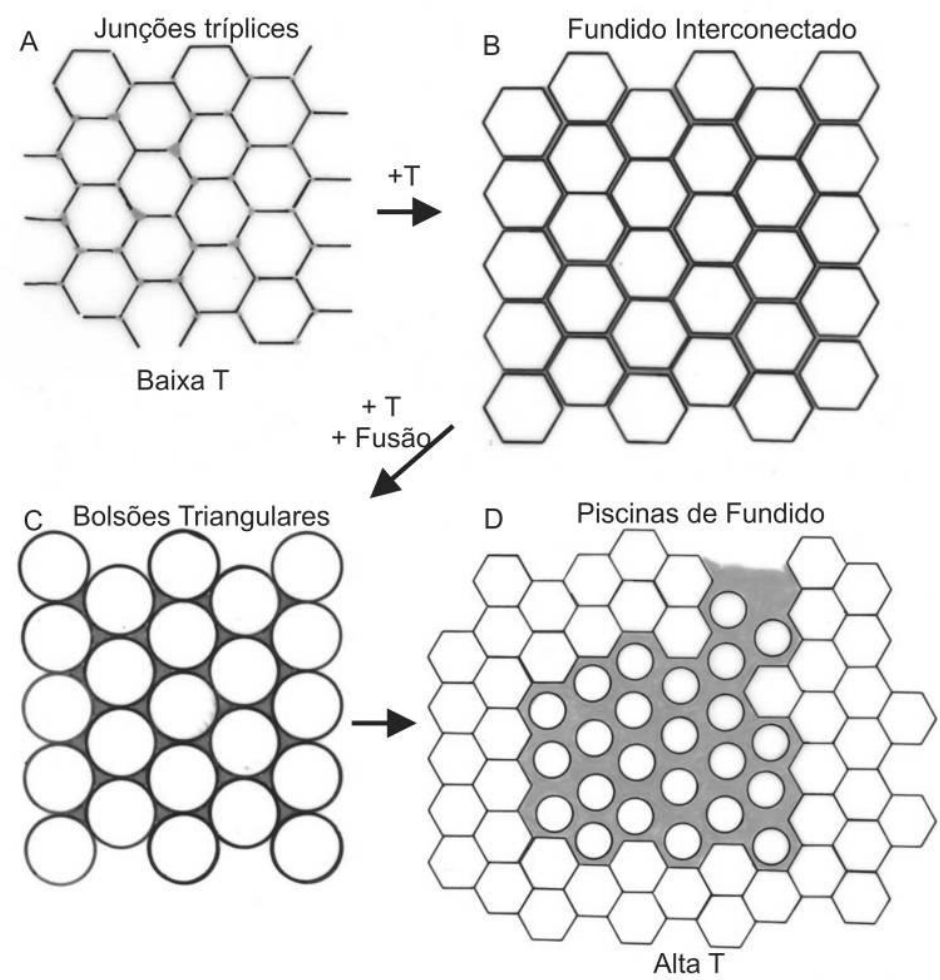

Alta taxa de Fusão

Figura 4 - Esquema sequencial mostrando o início da fusão parcial nas junções tríplices (A), seguido pela interconexão do fundido através das bordas dos grãos (B). Com o aumento da taxa de fusão, os minerais reagentes começam a ficar corroídos e arredondados, formando bolsões de fundido com forma triangular (C). Sob alta temperatura e alta taxa de fusão, formam-se piscinas de fundido (melts pools) contendo inclusões arredondadas e corroídas de minerais reagentes (D). Extraído do Short Course of Migmatites dado por Edward W. Sawyer.

Por representarem a pré-existência de fundido, esses grãos são chamados de interserts, pseudomorphs after melt ou melt pseudmorphs. Quartzo, feldspato potássico, plagioclásio, cordierita e biotita são os principais pseudomorfos de fusão. Raramente, os pseudomorfos de fusão são iguais aos cristais encaixantes, e quando iguais, apresentam diferentes composições (e.g. diferentes teores de anortita). Alguns pseudomorfos cristalizam cristais únicos e perfeitos enquanto que outros mostram um líquido sendo substituído por um intercrescimento polifásico. Holness \& Sawyer (2008) mostram que isso tem a ver, principalmente, com o tamanho dos poros e com a topologia do fundido.

\subsubsection{Tamanho dos Poros e Topologia do Fundido}

A geração de pseudomorfos monocristalinos ou de intercrescimentos a partir de um líquido anatético está intimamente ligada ao tamanho dos poros preenchidos pelo fundido. Quanto menor o poro, maior a barreira para a nucleação e crescimento de distintas fases minerais a partir do líquido anatético em uma cristalização cotética. Poros pequenos requerem a supersaturação do fundido para cristalizar 
uma fase única. Tal supersaturação pode ser atingida devido ao sobrecrescimento de determinada fase mineral nas paredes do poro. Um exemplo seria um quartzito anatético em que há sobrecrescimento de quartzo nas paredes do poro e uma supersaturação do líquido em plagioclásio, sendo que este irá formar um pseudomorfo monocristalino.

Poros maiores não apresentam uma barreira para a nucleação, e geram intercrescimentos polifásicos geralmente representados por intercrescimentos granofíricos. Cesare et al. (2009) estudaram inclusões de fundido em porfiroblastos de granada e observaram que as maiores inclusões cristalizaram feldspato potássico, plagioclásio, quartzo e biotita no chamado nanogranito, enquanto que as inclusões menores simplesmente se mantiveram como vidro.

Além do pequeno tamanho do poro, Holness \& Sawyer (2008) afirmam que os pseudomorfos monocristalinos também são caracterizados pelos baixos ângulos dihedrais. Tais ângulos mostram a relação entre duas fases sólidas em equilíbrio com uma fase fluida, no caso, o líquido anatético. A importância do ângulo dihedral está na topologia do fundido através da rocha (Figura 4.1) e de sua evolução com o reequilíbrio textural nos estágios finais e posteriores da cristalização. Para a maior parte dos materiais formadores da crosta, o ângulo dihedral é menor do que $60^{\circ}$, sendo que essa geometria permite, mesmo em rochas pouco porosas, a conectividade entre os diversos bolsões de fundido através da rocha sem que haja a necessidade de fatores externos como gradientes de pressão. Ângulos dihedrais maiores do que $60^{\circ}$ não permitem a movimentação do fundido (mesmo com altas taxas de fusão) através da rocha, exceto pela atuação da deformação (Holness et al. 2011).

Durante o reequilíbrio textural tardio, pós-deformacional e após a cristalização do fundido, os ângulos dihedrais tendem a aumentar para atingir o equilíbrio termodinâmico com geometrias cerca de $120^{\circ}$, podendo chegar a desenvolver ângulos de até $180^{\circ}$. Entretanto, como os menores poros apresentam maior dificuldade de nucleação, o tempo para seu reequilíbrio textural é muito menor daquele levado por poros grandes que se consolidam antes, mantendo-se com baixos ângulos dihedrais.

A interconexão do fundido através da rocha, evidenciada pelos ângulos dihedrais menores do que $60^{\circ}$, é fundamental para a formação de pseudomorfos monocristalino. Uma supersaturação efetiva pode ser atingida por meio da difusão de determinadas fases através dos canalículos interconectados. 

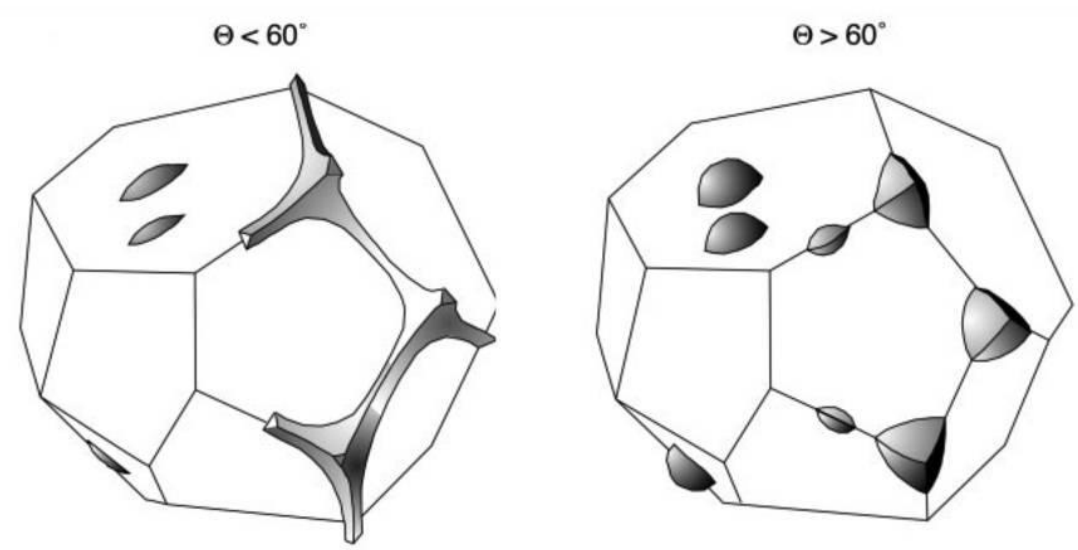

Figura 4.1 - llustração esquemática da topologia do líquido anatético com diferentes ângulos dihedrais $(\Theta)$. Quando o ângulo é menor do que $60^{\circ}$, o líquido anatético consegue migrar através das bordas dos grãos para formar uma rede interconectada de fundido.

Dessa forma, o tamanho dos poros controla a cinemática de cristalização do fundido e podem influenciar na reologia do migmatito como um todo. Um migmatito que abriga o líquido anatético em poros pequenos vai demorar mais para cristalizar (i.e. formar os pseudomorfos monocristalinos) do que aqueles com poros grandes, devido à necessidade de supersaturação do fundido.

A presença de fundido em uma rocha é de grande importância para a reologia da crosta continental uma vez que influi na resposta dúctil à deformação. Em escala de grão, a deformação controlada por difusão ocorre de forma lenta o suficiente para permitir o equilíbrio entre as fases sólidas e o fundido. Entretanto, com o incremento da deformação, a topologia do líquido anatético é completamente controlada pela própria deformação (Marchildon \& Brown, 2002), independente do ângulo dihedral. Uma pequena quantidade de fundido intersticial aumenta as taxas de deformação, podendo induzir a troca de mecanismos deformacionais atuantes, como por exemplo, do dislocation creep para o diffusion creep.

De uma forma geral, são descritos dois tipos de topologias sin-tectônicas do fundido em escala de grão: um apresenta bolsões de melt alinhados à foliação metamórfica principal enquanto que outro apresenta bolsões alongados ortogonalmente à foliação. Sawyer (2001), Marchildon \& Brown (2002) e Závada et al. (2007) afirmam que a distribuição concordante do líquido anatético com a foliação está ligada a baixas taxas de fusão, isto é, menos de $2 \%$ em volume de melt. Quando o fundido está perpendicular à lineações de estiramento, por sobrepressão ou por cavitação (Závada et al., 2007), as taxas de fusão estão entre 2-4\% em volume. 


\section{CAPÍTULO 5}

\section{CONTEXTO GEOLÓGICO}

\subsection{A porção marginal sul do Cráton Sanfranciscano}

Durante o Neoproterozoico, importantes eventos orogênicos ocorreram de forma a aglutinar a porção ocidental do paleocontinente Gondwana. Tais eventos fazem parte da Colagem Orogênica Brasiliana (Brito Neves et al., 1999) e estão hoje registrados nos terrenos pertencentes às Províncias Tocantins e Mantiqueira. A primeira abrange os orógenos Araguaia, Paraguai e Brasília e a segunda é composta pelos orógenos Araçuaí e Ribeira (no segmento centro-setentrional da província), e Apiaí e Dom Feliciano na porção centro-meridional. A porção marginal sul do Cráton Sanfranciscano compreende o Orógeno Brasília Meridional, o qual registra episódios de subducção e colisão durante o Ediacarano como resultado do fechamento do paleo-oceano Goianides. Esse evento orogênico aglutinou a Placa Paranapanema (margem ativa) e a Placa Sanfranciscana (margem passiva).

Os diferentes ambientes tectônicos e etapas orogências permitiram organizar o Orógeno Brasília Meridional em uma pilha colisional de nappes sin-metamórficas (Figura 5) que foram colocadas sobre o domínio cratônico com deformação do tipo thick-skin, gerando uma vergência tectônica para ENE. A estrutura alóctone mais antiga e interna do orógeno é a Nappe Socorro-Guaxupé, a qual representa um ambiente de arco magmático instalado na borda da Placa Paranapanema. Sobreposto, segue o Sistema de Nappes Andrelândia que corresponde a um fragmento de crosta continental subductada. $\mathrm{O}$ alóctono mais jovem, e que perfaz a base da pilha colisional, é composto pelos Sistemas de Nappes Carrancas e Lima Duarte, os quais apresentam afinidades de margem passiva (Campos Neto \& Caby, 2000; Trouw et al., 2000; Campos Neto et al., 2004).

A evolução desse conjunto de nappes é interpretada como resultado de um único ciclo orogênico, parcialmente controlado por channel flow (Beaumont et al., 2004), e com migração da frente orogênica em direção ao domínio cratônico (Campos Neto et al., 2011). A dinâmica da migração pode ser observada pela variação da idade do pico metamórfico das nappes superiores em relação às basais. A Nappe Socorro-Guaxupé apresenta pico metamórfico em $625 \mathrm{Ma}$, o sistema 
Andrelândia entre 610 e $605 \mathrm{Ma}$ e o Carrancas entre 590 e $570 \mathrm{Ma}$ (Campos Neto et al., 2011). Além disso, associações magmáticas e alguns depósitos sin-orogênicos também evidenciam a estabilização de domínios internos em relação à frente orogênica.

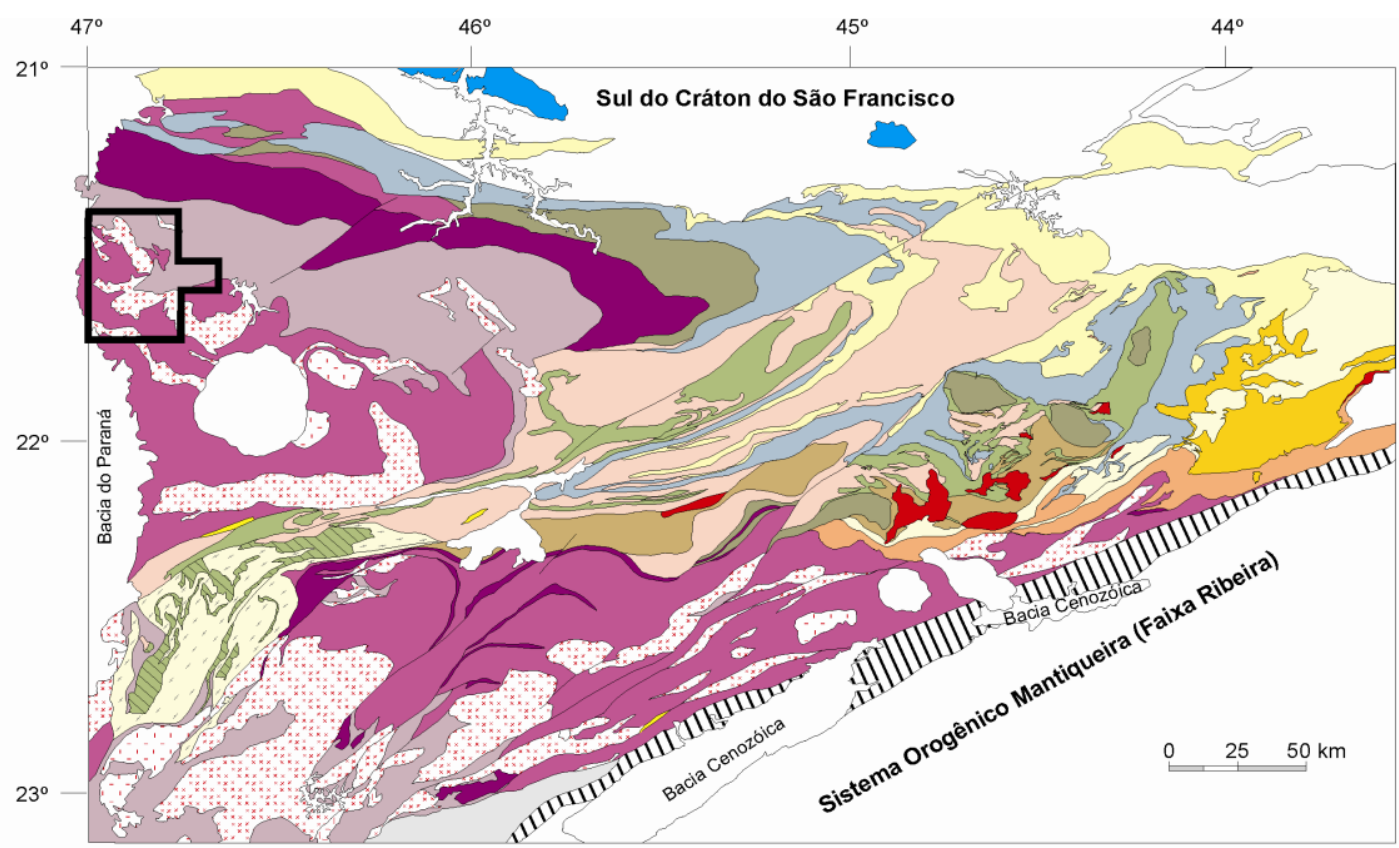

Remanescentes de bacias pós-orogênicas (Ediacarano-Cambriano)
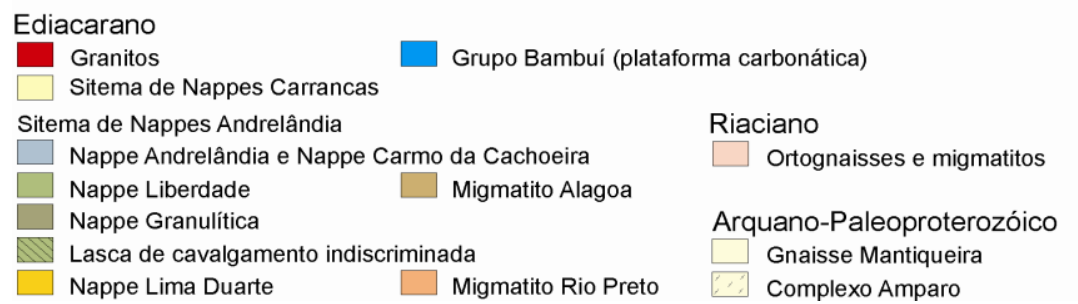
Criogeniano-Ediacarano Nappe Socorro-Guaxupé
Granitos tardi- a pós-orogênicos
Granitos sin-orogênicos
Unidade Metatexítica
Unidade Diatexítica
Unidade Granulítica
Paleoproterozóico-Mesoproterozóico
$\square$ Grupos São Roque e Serra do Itaberaba

Figura 5 - Quadro tectônico do Orógeno Brasília Meridional na porção marginal sul do Cráton do São Francisco com área de estudo indicada (Campos Neto et al., 2010).

Os maciços sieníticos pós-colisionais Capituva e Pedra Branca (Janasi et al., 1993), colocados na porção norte da Nappe Socorro-Guaxupé, apresentam idade de $610 \mathrm{Ma}$. A composição desses magmas está relacionada à fusão do manto litosférico subcontinental, provavelmente devido à ascensão do manto astenosférico. Acredita-se que a quebra do slab durante o processo de colisão entre os blocos Paranapanema e São Francisco tenha possibilitado a aproximação da astenosfera (Janasi et al., 2009). O adelgaçamento da listosfera no domínio interno do orógeno durante o colapso extensional deve ter permitido, há ca. $580 \mathrm{Ma}$, a granitogênese pós-orogênica do Cinturão Itu (Vlach et al., 1990). Este colapso da retaguarda 
orogênica ocorreu contemporaneamente ao pico metamórfico e espessamento da crosta na frente orogênica (Sistema de Nappes Carrancas e Lima Duarte).

A exumação do orógeno está documentada em bacias sucessoras com evolução sedimentar de continental a marinho raso (e.g. Pico do Itapeva, Pouso Alegre e Eleutério) com idades fossilíferas de 570 a 540 Ma e idade isotópica de área fonte mais jovem do que $600 \mathrm{Ma}$ (Teixeira, 2000). Seixos de hornblenda-biotita granitóides porfiríticos indicam a erosão de porções profundas do orógeno.

Para alguns autores (e.g. Ebert, 1984; Trouw et al., 2000; Peternel et al., 2005; Trouw et al., 2011), a evolução da porção marginal sul do Cráton do São Francisco ocorreu segundo dois eventos metamórfico-deformacionais associados ao avanço da Faixa Ribeira sobrepondo estruturas pré-existentes da Faixa Brasília, configurando uma zona de interferência. Zuquim et al. (2011) propõem uma evolução, no contexto da zona de interferência, iniciando com uma compressão ENE-WSW com transporte tectônico para ENE em fácies granulito, associada às nappes da Faixa Brasília ca. 625-605 Ma. Há 586 Ma teria ocorrido a colisão da Faixa Ribeira, agora com uma compressão NW-SE, desenvolvendo zonas de cisalhamento dúcteis sinistrais. Entre 580-560 Ma, ainda durante o desenvolvimento da Faixa Ribeira, uma rotação anti-horária do campo de esforços para WNW-ESE em condições dos fácies xisto verde até anfibolito inferior, teria configurado o padrão dextral geral da Faixa Ribeira.

Entretanto, para Campos Neto et al. (2004), o metamorfismo e a deformação das bacias sucessoras ao Orógeno Brasília Meridional, há cerca de $555 \mathrm{Ma}$, representam o registro da docagem do sistema orogênico Mantiqueira. As grandes zonas de cisalhamento NE e ENE apresentam movimentação dextral e temperaturas mais baixas, compatível com o deslocamento lateral do Terreno Embu.

\subsection{A Nappe Socorro-Guaxupé (NSG)}

A Nappe Socorro-Guaxupé é uma espessa (ca. $10 \mathrm{Km}$ ) pilha alóctone de três unidades distintas que representam uma seção de crosta continental profunda e parcialmente fundida (Campos Neto \& Caby, 2000). A estrutura é segmentada em dois lobos separados por rampas laterais de alto ângulo, sendo a norte o Domínio Guaxupé, e a sul o Domínio Socorro. Entre os dois lobos afloram rochas pertencentes ao Sistema de Nappes Andrelândia (Figura 5). 
De forma geral, a nappe apresenta uma foliação metamórfica recumbente com leve mergulho para sudoeste associada com lineações minerais e/ou de estiramento. A mudança de direção dessas lineações de WNW para ENE e indicadores cinemáticos com topo para leste indicam uma cinemática de cavalgamento paralela à borda sul do Cráton do São Francisco (Campos Neto et al., 2011). As diferentes lineações permitiram a distinção de pelo menos três eventos tectono-metamórficos (Campos Neto \& Caby, 2000). O primeiro está preservado nos granulitos basais da nappe que apresentam uma lineação mineral/estiramento com leve caimento para W-SW associada a indicadores cinemáticos com assimetria, em cavalgamento, para nordeste. Dobras isoclinais e em bainha também indicam um transporte principal para nordeste. O segundo evento está relacionado a um cisalhamento sin-metamórfico normal-oblíquo. No topo da unidade basal granulítica, lineações de estiramento NW-SE e indicadores cinemáticos são consistentes com movimentação normal para $\mathrm{W}$. Um evento tardi-metamórfico admite dobramento assimétrico e quase-recumbente, vergente para norte e associado a planos de cavalgamento. O conjunto do lobo Guaxupé da nappe foi ainda encurtado por dobras normais, orientadas E-NE e de até $30 \mathrm{~km}$ de meio comprimento de onda.

As associações litoestratigráficas da nappe Socorro-Guaxupé admitem três unidades principais (Campos Neto \& Caby, 2000; Campos Neto et al., 2004):

- Unidade Granulítica Basal: formada por granulito-gnaisses bandados enderbíticos a charno-enderbíticos caracterizados pela assembléia mineral Grt-CpxOpx-PI-Qtz em rochas máficas e Grt-Sil-Crd-Spl-Bt-PI-Qtz como assembléia de reequilíbrio em metapelitos. Junto a estes granulitos, ocorrem leucossomas e veios de charnokitos hololeucocráticos, que desenvolvem estruturas estromáticas e são interpretados como fusões anidras in situ, além de intercalações de camadas de ortognaisses migmatíticos gabro-noríticos, em direção ao topo da unidade;

- Unidade Diatexítica Intermediária: corresponde a biotita-hornblenda diatexitos estromáticos descontínuos, que predominam como hornblenda-biotitaclinopiroxênio gnaisse de composição diorítica-tonalítica, com leucossomas biotíticos alternados com melanossomas ferro-magnesianos. Estes migmatitos são envoltos por biotita-hornblenda granitos (nebulitos) e por granitos porfiríticos deformados. No topo da unidade predominam hornblenda tonalitos e biotita-hornblenda tonalitos a gnaisses granodioríticos com lentes metabásicas e bandas estromáticas leuco-

\footnotetext{
* Quando utilizadas, as abreviações minerais seguem o trabalho de Kretz (1983).
} 
tonalíticas a trondhjemíticas. Ocorrem ainda enclaves de rochas metassedimentares com assembleias Spl-Sil-Cdr-Grt;

- Unidade Metatexítica Superior: representada por migmatitos pelíticos a semi-pelíticos nos quais o grau de anatexia decresce da base para o topo. São mica xistos peraluminosos localmente intercalados com leucossomas a muscovita e lentes subordinadas de quartzito, gnaisse cálcio-silicático, raros mármores e metamáficas intrusivas.

Além das unidades principais, ocorrem importantes suítes magmáticas sintectônicas datadas por U-Pb em zircão, como o magmatismo cálcio-alcalino do Batólito Socorro (629 \pm 8 Ma, Topfner, 1996; e $610 \pm 10$ Ma, Ebert et al. 1996), do batólito Pinhal-Ipuiúna (622-619 Ma, Janasi, 1999) e da suíte granito-mangerítica São José do Rio Pardo, datada nos mangeritos da região de Divinolândia em $625 \pm$ 7 Ma (Basei et al., 1995).

Ocorrem também suítes graníticas interpretadas como resultado de anatexia, como é o caso dos biotita granitos equigranulares do tipo Pinhal (Wernick \& Penalva, 1980), datados em $625 \pm 3$ Ma (Janasi, 1999), e dos granada-biotita granitos do tipo Nazaré Paulista (Campos Neto et al., 1983; Wernick et al., 1987), datados em $624 \pm$ 2 Ma (Janasi, 1999).

A granitogênese tardi-orogênica é representada pelos granitos do Cinturão Itu que variam entre 590-580 Ma (Janasi et al., 2009), pelos sienitos potássicos do Maciço Capituva e Pedra Branca, com 610 Ma (Carvalho \& Janasi, 2012; Janasi et al., 1993; Topfner, 1996) e pelos dioritos potássicos do maciço Piracaia, com $581 \pm$ 13 Ma (Janasi, 1986).

O comportamento metamórfico da NSG é de ultra-alta temperatura com pressões altas na base e baixas nas unidades superiores. A Unidade Granulítica Basal admite uma anatexia anidra em fácies granulito com ca. $900^{\circ} \mathrm{C}$ e $12 \mathrm{Kbar}$ (Campos Neto \& Caby, 2000; Janasi, 2002). Essas condições metamórficas ilustram o pico metamórfico, datado entre 635 e 625 Ma (e.g. Basei et al., 1995; Janasi, 1999; Martins et al., 2009; Reno et al, 2009). As unidades superiores, dominadas por rochas migmatíticas, apresentam aquecimento em trajetória quase isobárica chegando até $900^{\circ} \mathrm{C}$ e 6,5 Kbar (Campos Neto et al., 2004). Metatexitos superiores do Domínio Socorro apresentam temperaturas mais baixas, ca. $750^{\circ} \mathrm{C}$. Somente no lobo sul, Socorro, da nappe estão reportadas idades de metamorfismo do fácies anfibolito superior, com geração de líquido silicático e corpos graníticos, com 
duração de cerca de $25 \mathrm{Ma}$, de ca. $635 \mathrm{Ma}$ a $607 \mathrm{Ma}$ (Vlach \& Gualda, 2000; Negri et al., 2005; Martins et al., 2009).

O forte gradiente termal, mesmo em baixas profundidades, é análogo a ambientes de margem ativa com manto astenosférico raso, podendo, então, ser relacionado à raiz profunda de um arco magmático (Campos Neto et al., 2004). O comportamento isotópico $\mathrm{Nd}_{\mathrm{TDM}}$ para os diferentes tipos de granulitos e metassedimentos da NSG sugere uma mistura de material neoproterozoico juvenil e crosta continental mais antiga. No Domínio Guaxupé, granulitos migmatíticos apresentam $\varepsilon \mathrm{Nd}_{625}$ mais negativos do que -10 e idades $T_{D M} \geq 1,8 \mathrm{Ga}$, correspondendo a um núcleo antigo de embasamento. Rochas graníticas anatéticas e, aparentemente, com pouco deslocamento através da crosta, também possuem $\varepsilon \mathrm{Nd}_{(625)}$ mais negativos do que -10 . Granulitos, ortognaisses e rochas

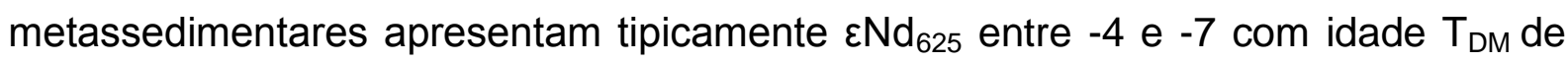
1,5 Ga e correspondem a um bloco crustal mais jovem (Janasi, 1999).

A NSG representa então a raiz profunda de um arco magmático, construído na margem ativa da Placa Paranapanema em convergência do tipo Andino (Campos Neto et al., 2011). Idades de $645 \mathrm{Ma}$ (Braga, 2002) remontam à atividade do arco durante a subducção com pico metamórfico de ultra-alta temperatura há cerca de $625 \mathrm{Ma}$ e relaxamento térmico colisional entre 617-607 Ma. A exumação do lobo norte, Guaxupé, da NSG se deu por volta de $610 \mathrm{Ma}$, idade de colocação dos maciços sieníticos pós-colisionais.

\subsection{A porção W-SW do Domínio Guaxupé}

Na porção W-SW do Domínio Guaxupé, a Unidade Diatexítica Intermediária é representada por litotipos agrupados nas suítes Granito-Migmatítica Pinhal e Granito-Mangerítica São José do Rio Pardo.

A suíte Granito-Mangerítica São José do Rio Pardo (Campos Neto \& Figueiredo, 1988) é formada por corpos tabulares dobrados resultantes do fracionamento in situ de magmas primários mangeríticos e quartzo-mangeríticos. Os baixos conteúdos de $\mathrm{Ca}, \mathrm{Sr}$ e \#mg e altos conteúdos de $\mathrm{Zr}$ dão à suíte uma assinatura geoquímica intra-placa (Campos Neto et al., 1988). Todas as rochas que compõem os diferentes maciços da suíte encontram-se fortemente deformadas, com redução do tamanho dos grãos por recristalização dinâmica e quase completa obliteração das texturas ígneas. 
Os principais litotipos são mangeritos e quartzo-mangeritos verde escuros de granulação média a grossa com cerca de $10 \%$ de minerais máficos (Janasi, 1997). Os mangeritos dominam em uma tendência composicional de norito-jotunitomangerito-charnoquito (Campos Neto \& Figueiredo, 1985). Em alguns afloramentos, os mangeritos ocorrem como leucossomas de granulitos regionais de granulação médio-fina e estrutura bandada. Os mangeritos podem apresentar enclaves escuros, dioríto-noríticos de granulação fina. Gradam para hornblenda granitos rosados com texturas similares. Em contatos retos e abruptos, ocorrem também granitos rosados hololeucocráticos, com hornblenda \pm biotita. $\mathrm{O}$ quartzo e $\circ$ feldspato potássico exibem um alinhamento estatístico preferencial definindo uma lineação mineral e/ou de estiramento mineral.

A suíte Granito-Migmatítica Pinhal, inicialmente descrita por Wernick \& Penalva (1980), apresenta uma associação de rochas graníticas, citadas como "granitos formadores de migmatitos" ou granitos do tipo Pinhal, circundadas por uma auréola de migmatitos. Campos Neto \& Figueiredo (1985) descrevem as rochas graníticas como rochas rosadas a rosa-acinzentadas leuco- a hololeucocráticas com textura hipidiomórfica a granoblástica, inequigranulares médias a grossas e estrutura foliada a gnáissica. São rochas que variam de granodioritos, monzogranitos, sienogranitos até álcali-feldspato sienitos. A biotita é o principal mineral máfico e a hornblenda muito rara. Esses granitos apresentam ainda estruturas migmatíticas como a nebulítica e a schliere, encerram enclaves gnáissicos e apresentam estruturas de injeção, podendo ser interpretados como neossomas. A diferença entre os granitos rosados do tipo Pinhal e os granitos rosados da suíte São José do Rio Pardo é que os primeiros apresentam-se fracamente foliados e ricos em biotita, enquanto que os últimos apresentam-se fortemente lineados e ricos em hornblenda (Janasi, 1997). Dois tipos petrográficos de granitos peraluminosos também podem ocorrer, sendo um de cor branca e composição leucotonalítica com granada e outro róseo também com granada.

As rochas anatexíticas são representadas por migmatitos ocelares e estromáticos (Campos Neto \& Figueiredo, 1985). Os primeiros são cinza a rosados com megacristais deformados de feldspato alcalino em uma matriz inequigranular grossa de composição monzogranítica a quartzo-monzonítica, enquanto que os últimos caracterizam-se por bandas leucossomáticas de composição granítica quartzo-sienítica envoltos por melanossomas ricos em biotita e opacos \pm hornblenda e mesossomas cinza e inequigranulares de composição granítica a granodiorítica. 
Já a Unidade Metatexítica Superior, tem seus principais litotipos agrupados no Complexo Metamórfico Caconde e se associam a rochas diatexíticas.

O Complexo Metamórfico Caconde (Campos Neto \& Figueiredo, 1985) admite dois grupos de rochas, sendo uma sequência metassedimentar (ou metavulcanossedimentar) e outra ortoderivada. Esta última é composta por biotitahornblenda (granada) gnaisses bandados com frequentes intercalações decimétricas de anfibólio-piroxênio gnaisse cinza escuro e boundins de anfibolito, biotitahornblenda gnaisses dioríticos finos e ortognaisses dioríticos na zona do hyperstênio (Campos Neto \& Figueiredo, 1985). Tal unidade dos gnaisses bandados é metatexítica.

A sequência metassedimentar admite gnaisses quartzosos cinza claros com intercalações de quartzitos, anfibolitos com intercalações de rochas calciossilicáticas, ortoquartzitos e quartzitos micáceos recristalizados e granada gnaisses de composição granítica a tonalítica associados a kinzigitos com silimanita e cordierita.

A associação de rochas diatexíticas envolve granitoides com estrutura homogênea a schliere contendo enclaves de rochas anfibolíticas, hornblenda gnaisses de composição diorítica e de rochas charnoquíticas. São basicamente hornblenda monzo- a sienogranitos e quartzo-sienitos róseos hipidiomórficos inequigranulares de granulação grossa que transicionam para fácies com ortopiroxênio enderbíticas a quartzo-noríticas e finalmente a fácies com clinopiroxênio tonalíticas. Tais granitóides diferenciam-se daqueles róseos da suíte São José do Rio Pardo por contarem com abundantes estruturas migmatíticas, como schliere, e por possuirem maior porcentagem modal de clinopiroxênio. 


\section{CAPÍTULO 6}

\section{DESCRIÇÃO DAS UNIDADES LITOLÓGICAS}

A porção sul-ocidental do Domínio Guaxupé, da Nappe Socorro-Guaxupé, abrange os limites das cidades de São Sebastião da Grama (SP), São José do Rio Pardo (SP), Mococa (SP), Tapiratiba (SP), Arceburgo (MG) e Caconde (SP). Os mapas geológicos 1:50.000 das folhas São José do Rio Pardo (SF-23-V-C-VI-I) e Guaranésia (SC-23-V-C-III-3) de Campos Neto et al. (1985), integrados com o mapa geológico 1:25.000 da folha Caconde (SF-23-V-C-VI-2-NO) de Oliveira et al. (1989), estão apresentados no mapa em anexo. As descrições apresentadas a seguir estão baseadas nas observações dos trabalhos de campo deste projeto.

\subsection{Unidade Granulítica Basal}

A Unidade Granulítica Basal é a única que não está representada no mapa geológico aqui apresentado. Os afloramentos visitados encontram-se na Folha Guaxupé - articulação norte da Folha Caconde -, a qual está mapeada somente em escala regional (Cavalcante et al., 1979).

Os principais afloramentos ocorrem como cortes de estrada ou em pedreiras. O litotipo predominante é um clinopiroxênio-hornblenda granulito charnockítico a jotunítico com estrutura bandada e granulação fina a média. A rocha apresenta bandas verde-escuras e bandas cinza-escuras (Figura 6). Em proporção modal, os minerais máficos representam $>35 \%$ da rocha, sendo hornblenda, clinopiroxênio, ortopiroxênio e biotita. Os minerais acessórios são apatita, zircão e opacos.

O bandamento desses granulitos é conferido pela separação de finas bandas granoblásticas quartzo-feldspáticas (ca. $2,5 \mathrm{~mm}$ de espessura) por lâminas submilimétricas nematoblásticas ricas em hornblenda (Prancha I.A). 

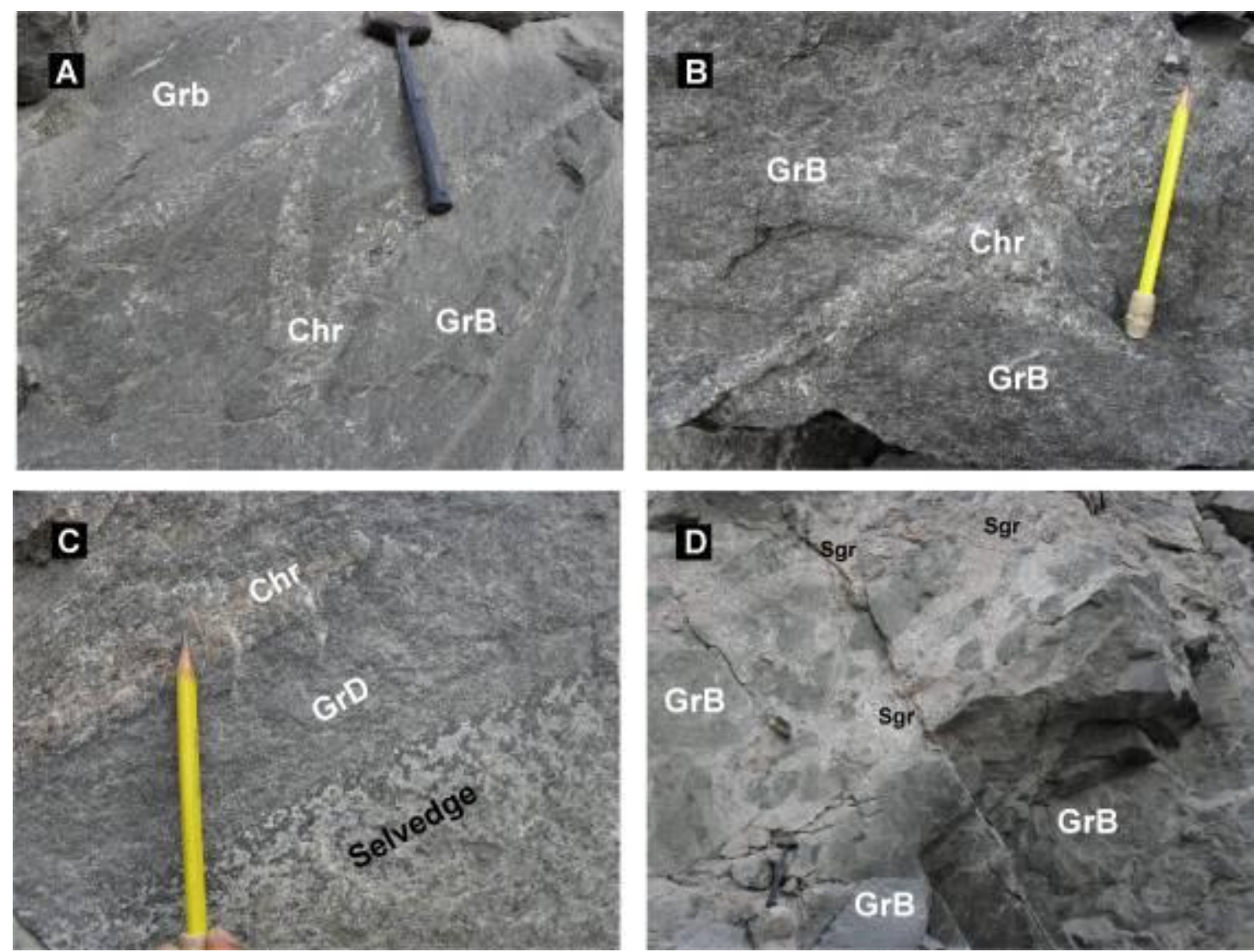

Figura 6 - (A) Granulitos bandados (GrB) de cor cinza a verde com rocha charnoquítica (Chr); (B) Injeção de rocha charnoquítica nos granulitos bandados; (C) Geração de selvedge de hornblenda + plagioclásio a partir da injeção de rochas granodiorítica $(\mathrm{GrD})$ fina entre os granulitos bandados e charnoquítos foliados; (D) Granulitos bandados com injeção de rochas sienogranítica rosada hololeucocrática (Sgr) contendo enclaves angulosos a levemente arredondados de granulitos máficos.

As bandas granoblásticas são inequigranulares, de granulação fina a média, com contatos entre grãos interlobados a poligonizados. Ocorrem variações em que são comuns porfiroclastos simétricos de feldspatos micropertíticos associados a ribbons de quartzo com forte extinção ondulante e em tabuleiro de xadrez. Intercrescimentos mirmequíticos não são raros. São observados também pseudomorfos de fusão mimetizados por plagioclásio (Prancha I.B). Os cristais de ortopiroxênio, que ocorrem nas bandas granoblásticas, possuem granulação grossa e formas subidioblásticas. No geral encontram-se substituídos, nas bordas, por biotita (Prancha I.C). Ocorrem também cristais alterados, através de fraturas e clivagens, a uma massa irregular e intersticial de cor amarela e associada a minerais opacos (Prancha I.D). Já as porções nematoblásticas, ricas em hornblenda tabular de pleocroísmo verde-escuro a castanho e que definem a foliação da rocha, apresentam aglomerados de clino- e ortopiroxênio de granulação fina (prancha I.E). Nessas bandas, a biotita ocorre tanto substituindo pelas bordas os demais minerais máficos, quanto como cristal bem formado associado a minerais opacos e apatita, além de formar intercrescimentos simplectíticos com o plagioclásio (Prancha I.F). 
Associados aos granulitos bandados, ocorrem rochas charnockíticas de granulação grossa e cor marrom que se encontram ou em formas dobradas (Figura 6.A) nos granulitos bandados ou ocorrem como filões de injeção com limites irregulares (Figura 6.B). Esses charnockitos apresentam uma textura granoblática inequigranular quartzo-feldspática com contatos interlobados a poligonizados. Os cristais de ortopiroxênio estão substituídos por clinopiroxênio ora em texturas coroníticas ora como inclusões em cristais bem formados de clinopiroxênio. A hornblenda, retrometamórfica, ocorre substituindo os cristais de clinopiroxênio e está também associada a cristais de biotita e opacos retrógrados.

A injeção de rochas granodioríticas de granulação fina entre os charnockitos marrons e os granulitos bandados geraram selvedges irregulares de hornblenda + plagioclásio nas bordas das injeções (Figura 6.C). Ocorrem também injeções de rochas sienograníticas hololeucoráticas rosadas ao longo da foliação dos granulitos bandados, que restam como enclaves angulosos (ou schollens) (Figura 6.D). O sienogranitos variam de estruturas maciças e muito grossas a gnáissicas de granulação média. Em lâmina delgada, é possível observar que predominam os feldspatos alcalinos pertíticos e que estes contêm inclusões euhédricas tabulares de plagioclásio. São muito comuns os intercrescimentos mirmequíticos. O quartzo apresenta caráter intersticial entre as faces ígneas dos feldspatos, por vezes apresentando extinção ondulante do tipo tabuleiro de xadrez. Essas rochas apresentam ainda hornblenda substituída por biotita, além de acessórios como titanita, zircão, apatita e minerais opacos.

Por último, foram descritos biotita-clinopiroxênio-hornblenda gnaisses de composição quartzo-monzonítica a granodiorítica de granulação fina a média. Apresenta estrutura foliada marcada por cristais idioblásticos tabulares de hornblenda, as quais claramente substituem cristais de clinopiroxênio e associam-se a minerais opacos. A biotita é dominantemente retrógrada nas bordas da honblenda. As porções granoblásticas apresentam-se inequigranulares interlobadas a poligonizadas e ocorrem como milimétricas camadas descontínuas segundo a foliação. Clorita retrógrada e alanita acessória estão presentes. 


\section{Prancha I - Unidade Granulítica Basal}
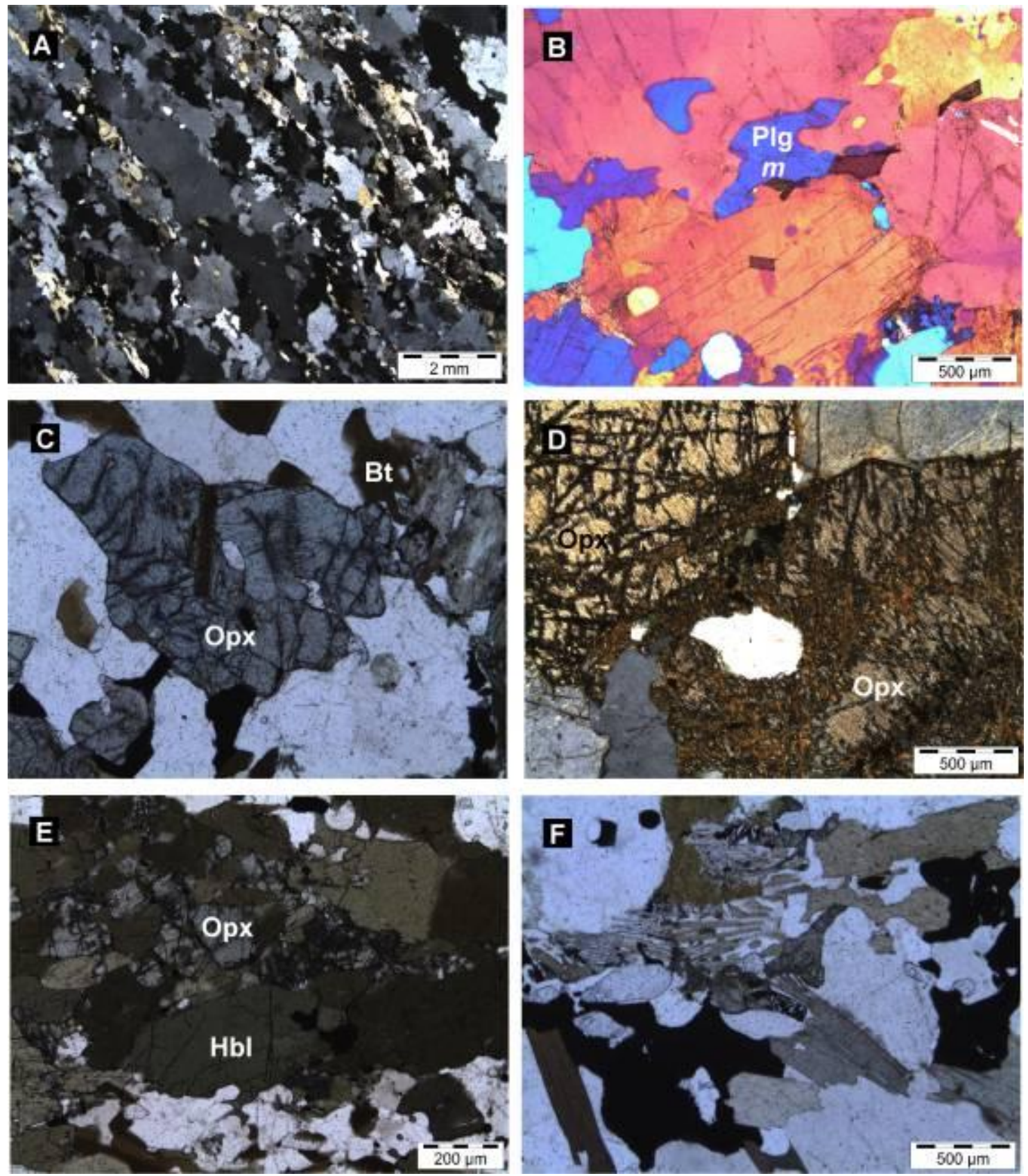

Prancha I - (A) Bandamento composicional dos granulitos bandados. As porções amarelas são lepidonematoblásticas com biotita e hornblenda, além de piroxênios granulares, e as porções cinzas são granoblásticas inequigranulares interlobadas a poligonizados de granulação fina a média; (B) Pseudomorfo de fusão de plagioclásio (Plg $\mathrm{m}$ ); (C) Cristal grosso de ortopiroxênio nas bandas granoblásticas, substituídos nas bordas por biotita; (D) Cristais de ortopiroxênio fortemente substituídos por mineral de alteração amarelo, e a polarizadores cruzados, como na foto, ficam castanho claro; (E) Cristais idioblásticos de hornblenda envolvendo aglomerados de ortopiroxênio; (F) Intercrescimentos simplectíticos entre biotita e plagioclásio. 


\subsection{Unidade Diatexítica}

Na porção sul-ocidental do Domínio Guaxupé, essa unidade é representada por litotipos agrupados nas suítes Granito-Migmatítica Pinhal e Granito-Mangerítica São José do Rio Pardo. Sua distribuição geográfica ocupa toda a porção sul da Folha Caconde, sul e noroeste da Folha São José do Rio pardo, estendendo-se até o sudoeste da Folha Guaranésia.

\subsubsection{Suite Granito-Migmatítica Pinhal}

$\mathrm{Na}$ área de estudo, a suíte Granito-Migmatítica Pinhal é dominada por rochas diatexíticas de estrutura e composição variadas. Ocorrem também rochas metatexíticas e blocos de quartzo-monzodioritos ricos em epidoto e clinozoisita.

\section{Granada-biotita diatexito schliere ${ }^{\dagger}$}

As exposições visitadas dessa unidade litológica ocorrem em forma de blocos in situ arredondados, geralmente em corte de estrada. A rocha apresenta um bandamento composicional cujas bandas apresentam pouca continuidade lateral, por vezes terminado em cunha ou em formas arredondadas e que apresentam diferentes estruturas diatexíticas (Figura 6.1A).

Bandas leuco- a mesocráticas, de cor branca a cinza e com cerca de $20 \mathrm{~cm}$ de espessura, apresentam principalmente textura granoblástica inequigranular média a grossa composta por quartzo e feldspato. Cristais de biotita definem lâminas descontínuas, lepidoblásticas, que caracterizam um diatexito schliere. Porfiroblastos com cerca de $2 \mathrm{~cm}$ de granada ocorrem arredondados e substituídos nas bordas por coronas de quartzo e feldspato (Figura 6.1B). O diatexito schliere, de composição granodiorítica, caracteriza-se por conter megacristais de plagioclásio que, apesar de bem facetados, têm suas geminações deformadas e associadas à extinção ondulante. A matriz é rica em cristais de quartzo que apresentam formatos de borda desde retilíneos, quando em contato com os megacristais de plagioclásio, até interlobados com microtexturas de migração de borda de grão, quando em contato com quartzo e plagioclásio granoblásticos finos. Estes plagioclásios, no

\footnotetext{
† Schliere refere-se a uma fina camada contendo minerais tabulares ou prismáticos alinhados em um migmatito diatexítico. Schlieren é forma no plural.
} 
geral, exibem uma sericitização. Cristais de biotita com pleocroísmo castanho a avermelhado ocorrem em concentrações lamelares lepidoblásticas tipo schlieren.
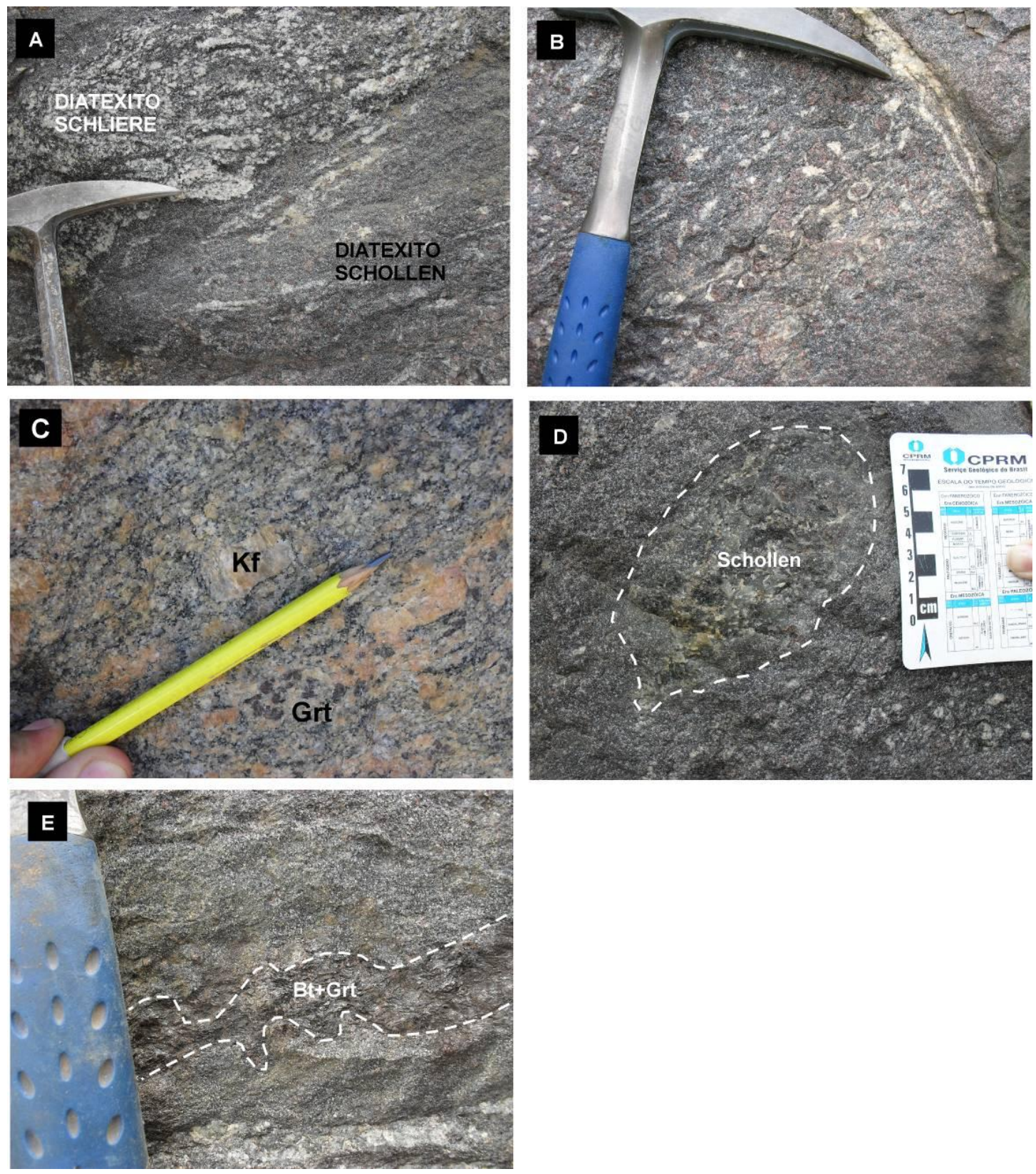

Figura 6. 1- (A) Relações difusas entre os diatextios schliere e schollen; (B) Feição coronítica de quartzo + plagioclásio em porfiroblastos de granada arredondados; (C) Fenocristal de feldspato alcalino (Kf) e cristais de granada dos biotita-granada diatexitos schliere rosados; (D) Enclave (ou schollen) granulítico com granada e feldspato verde no diatextio schollen; (E) Porções residuais difusas ricas em cristais grossos de biotita e granada no diatextio schollen.

São descritos também granada-biotita diatexitos schliere que apresentam principalmente porções quartzo-sieníticas rosadas com intercalações em contatos difusos com porções granodioríticas cinzas. As porções rosadas estão dobradas de forma assimétrica e alojadas em bandas extensionais de pares do tipo S-C', dispondo cristais subeuhédricos de feldspato alcalino nas bandas C' e recristalizados na S. Fenocristais de feldspato alcalino ocorrem nas porções granodioríticas (Figura 6.1 C). Ocorrem também schlieren de mineras máficos, 
dominantemente biotita, localizados nas charneiras de dobras assimétricas e em domínios extensionais. Em lâmina delgada, as porções rosadas apresentam microestruturas de fusão com topologias em cúspide e em filmes, além de conterem inclusões goticulares de quartzo+feldspato+clorita em porfiroblastos de granada, que podem estar amalgamados. A matriz é granoblástica inequigranular de granulação média a grossa com contatos entre grãos retilíneos a levemente lobados. Ocorrem cristais de andesina por vezes antipertíticos e microclínio. Os cristais de quartzo apresentam forte extinção ondulante, localmente em tabuleiro de xadrez, enquanto que os feldspatos estão raramente ondulantes. Quartzo e feldspato também estão intercrescidos em relações granofíricas.

\section{Granada-biotita diatexito schollen}

Separadas do diatexito schliere branco a cinza por finas camadas melanocráticas de biotita \pm granada, ocorrem bandas um pouco mais espessas, com cerca de $40 \mathrm{~cm}$ de espessura, de granda-biotita gnaisse que apresentam tons de cinza mais escuros e desenvolvem uma textura lepido-granoblástica equigranular fina a média marcada por biotita, quartzo e feldspatos, além de conter lâminas quartzo-feldspáticas hololeucocráticas brancas descontínuas (Figura 6.1A). Cristais de granada porfiroblásticos também ocorrem com coronas de substituição quartzofeldspáticas. Enclaves de rochas granulíticas com feldspato verde e cristais de granada, sugestivamente representando o paleossoma, e lentes difusas ricas em cristais grossos de biotita e granada, provavelmente residuais (Figura 6.1 D e E), caracterizam um diatexito schollen.

O diatexito schollen, de composição tonalítica a quartzo-diorítica, apresenta biotita $(\sim 30 \%)$, plagioclásio $(\sim 40 \%)$, quartzo $(\sim 20 \%)$, feldspato alcalino $(\sim 5 \%)$ e granada $(\sim 5 \%)$. Apatita, zircão, monazita, clorita, muscovita e opacos formam a mineralogia acessória. A matriz da rocha é rica em plagioclásio e quartzo em uma textura granoblástica equigranular com contatos entre grãos levemente lobados a retilíneos. Os contatos retos ocorrem constantemente quando o plagioclásio ou o quartzo estão em contato com cristais de biotita, a qual não chega a definir uma xistosidade. Os cristais de plagioclásio apresentam geminações polissintéticas que variam de pouco espaçadas a bem espaçadas. As primeiras indicam teor de anortita de $25 \%$ (oligoclásio) enquanto que as últimas $\sim 40 \%$ (andesina). Somente os cristais de andesina apresentam extinção ondulante e geminações levemente deformadas. 
Os cristais de quartzo apresentam extinção ondulante, e quando perto de porfiroblastos, desenvolvem extinção do tipo tabuleiro de xadrez.

Os porfiroblastos de granada apresentam duas gerações. Na primeira ocorrem cristais xenoblásticos ricos em inclusões, por vezes, poiquiloblásticos. As inclusões apresentam formatos irregulares goticulares e são compostos ou por quartzo ou por feldspato + quartzo (Prancha II.B). A segunda geração apresenta cristais de granulação mais grossa, subidioblásticos e com inclusões de biotita. Tais inclusões variam de arredondadas com pleocroísmo avermelhado a placóides, com pleocroísmo castanho. Os porfiroblastos apresentam bordas substituídas por biotita com pleocroísmo castanho a esverdeado. Quando estão em algumas bandas ricas em apatita, os cristais de granada estão substituidos na borda por clorita.

As porções melanocráticas, sugestivamente compondo um melanossoma, caracterizam-se pela alta concentração de cristais de biotita em uma textura lepidoblástica. Esses cristais são placóides e bem formados com pleocroísmo castanho a avermelhado. Distinguem-se de cristais de biotita mais finos e xenoblásticos intercrescidos com quartzo e plagioclásio. Os cristais de granada do melanossoma são xenoblásticos e de granulação média. São ricos em inclusões goticulares de quartzo + plagioclásio + biotita.

O diatexito schollen e as porções residuais apresentam importantes microestruturas de fusão. Os pseudomorfos de fusão são representados por cristais de quartzo cujas topologias variam desde triangulares em cúspide, típicas de junções tríplices (Prancha II.E-F), até filmes ao longo das bordas dos grãos (Prancha II.A e II.D). Localmente, é possível inferir uma evolução das topologias em cúspide para os filmes ao longo das bordas, com reequilíbrio estático em textura do tipo string of beads. Ocorrem também bolsões interlobados de líquido de fusão a partir do qual cristais de quartzo finos cristalizaram, tendendo a formas euhédricas (Prancha II.C). Por último, inclusões quartzo-feldspáticas \pm biotita em formas de gota nos cristais de granada também podem indicar a existência precedente de fundido (Prancha II.B).

\section{Biotita diatexito porfiroclástico}

Ocorrem como blocos in situ esferoidais e isolados, principalmente em cortes de estrada, não permite descrever como são as relações de contato com outros tipos litológicos. São rochas tipicamente leucocráticas rosadas de composições 
monzograníticas que gradam a granodioríticas acinzentadas (Figura 6. 2 A). Localmente observam-se gradações difusas para granitos de granulação fina e caráter aplítico. A estrutura geral é foliada com componente linear conferida pelo alinhamento de fitas (ribbons) de quartzo e de megacristais de feldspato. Feições nebulíticas com schlieren de biotita são abundantes e denotam um caráter diatexítico, além de estarem relacionadas a foliações do tipo S/C (Figura 6.2 A).

Megacristais de feldspato alcalino ocorrem como fenocristais subeuhédricos orientados segundo a foliação $S$, enquanto que a foliação $C$ é marcada tanto por porfiroclastos do tipo "phi" como por fenocristais que desenvolveram caudas em sigma (Figura 6. 2 B, C e D).

Em lâmina delgada, as porções granodioríticas apresentam uma matriz granoblástica inequigranular interlobada a serrilhada em que os cristais de quartzo apresentam extinção ondulante e feições de migração de borda na geração de subgrãos e ribbons. Os cristais de feldspato da matriz apresentam geminações deformadas e extinção ondulante, sem feições de migração de borda, podendo ser pertíticos a antipertíticos, alguns com caráter porfiroclástico. Fenocristais subeuhédricos de feldspato alcalino com cerca de $5 \mathrm{~mm}$ evidenciam textura ígnea hipidiomórfica e apresentam microexsoluções segundo seu eixo maior e fraturas sericitizadas ortogonais. Esses cristais apresentam leve extinção ondulante, inclusões de plagioclásio e contêm abundantes intercrescimentos mirmequíticos nas bordas. Os cristais de biotita castanhos a avermelhados, substituídos por clorita, marcam uma textura lepidoblástica descontínua e associam-se a minerais acessórios como opacos e apatita. Alguns pseudomorfos de fusão com topologia em filmes apresentam extinção ondulante.

As variações rosadas monzograníticas podem apresentar uma textura hipidiomórfica em que predominam cristais de feldspato alcalino pertítico bem facetados, com inclusões de plagioclásio euhédricos e tabulares. Cristais de microclínio ocorrem intersticiais e, assim como todos os feldspatos, altamente alterados. O quartzo apresenta forte extinção ondulante, chegando a desenvolver feições do tipo tabuleiro de xadrez. Dentre a mineralogia acessória, ocorrem minerais opacos, monazita e zircão. Localmente são observadas microestruturas de fusão com topologia em filmes. 

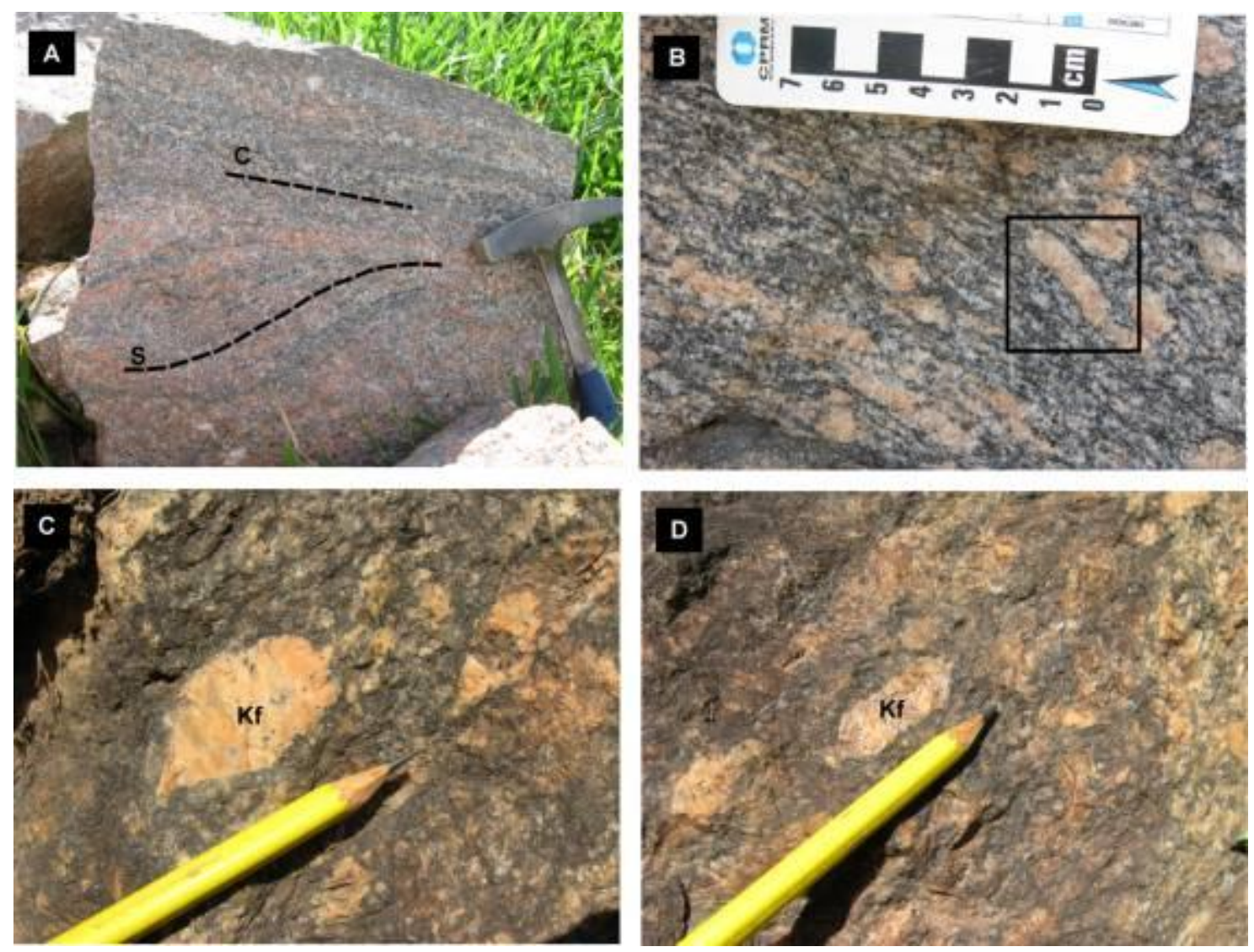

Figura 6. 2- Biotita gnaisse monzogranítico rosado diatexítico e porfiroclástico. (A) Foliação do tipo S/C mostrando a porção granodiorítica em $\mathrm{C}$ e monzogranítica rosada com schlierens em $\mathrm{S}$; (B) Cristal subeuhédrico de feldspato alcalino na foliação S; (C) Porfiroclasto de feldspato alcalino do tipo "phi"; (D) Fenocristal de feldspato alcalino com desenvolvimento de caudas em sigma nas extremidades. A disposição dos cristais da foliação $S$ e as lineações de estiramento mineral indicam topo para nororeste.

\section{Metatexito monzogranítico}

Os gnaisses metatexíticos ocorrem em blocos in situ aos pés de pequenos morros. A rocha apresenta estrutura migmatítica estromática dobrada, onde claramente separam-se leucossoma, melanossoma e palessoma. O leucossoma é branco a levemente rosado de composição granítica e textura fanerítica média a grossa, chegando a preservar cristais de feldspato alcalino subeuhédricos. Encontram-se dobrados em isoclinais assimétricas e também orientados no plano axial de dobras rompidas.

Uma fina camada melanocrática rica em biotita separa o leucossoma do paleossoma. Este, de composição monzogranítica, apresenta granulação fina a média e cor cinza. São comuns bandas extensionais de cisalhamento, concordantes com a assimetria das isoclinais. Em lâmina delgada, observa-se uma matriz com textura granoblástica inequigranular interlobada a levemente serrilhada rica em quartzo, microclínio e andesina. Todos apresentam extinção ondulante e o quartzo 
recristalização com migração de borda. Microestruturas de fusão também ocorrem na matriz, geralmente com topologias triangulares em cúspide e alguns filmes ou canalículos.

Fenocristais subeuhédricos de labradorita ocorrem como relíquias magmáticas associados a porfiroclastos de feldspatos mesopertíticos. Esses megacristais encontram-se orientados segundo a foliação marcada pela fábrica de forma do quartzo e orientação dos cristais de biotita, as quais apresentam pleocroísmo castanho a marrom claro. Os minerais acessórios são basicamente de substituição, como clorita, retrógrada à biotita, e epidoto, de saussuritização.

\section{Hornblenda-clinozoisita-epidoto quartzo-monzodiorito}

Trata-se de rochas que afloram como blocos in situ e rolados em estradas de terra. Apresentam um bandamento composicional com leitos ricos em quartzo + plagioclásio + biotita, leitos ricos em plagioclásio + feldspato alcalino e leitos com fenocristais de hornblenda e vênulas ricas em epidoto. Em lâmina delgada, a mineralogia principal é: plagioclásio (40\%), hornblenda (15\%), quartzo (10\%), biotita $(10 \%)$, clinozoisita (10\%), epidoto (5\%), apatita (4\%); e minerais acessórios como monazita e magnetita e retrógrados como muscovita e clorita.

Observa-se uma textura ígnea fanerítica hipidiomórfica inequigranular fina a média. Tanto os cristais de quartzo como os de feldspato apresentam extinção ondulante, além de forte sericitização e/ou saussuritização. Os fenocristais de hornblenda chegam a $3 \mathrm{~mm}$, com pleocroísmo verde a castanho claro. Quartzo goticular e cristais granulares a aciculares de minerais máficos ocorrem como inclusões. Nas bordas, o anfibólio é substituído por biotita cloritizada. Os cristais de epidoto são granulares e ocorrem nas porções da matriz mais rica em biotita e opacos. A clinozoisita, ocorrendo nas bordas do epidoto, pode ser de substituição.

\subsubsection{Suite Granito-Charnoquítica São José do Rio Pardo}

Os representantes graníticos da suíte São José do Rio Pardo nessa porção da NSG são representados por hornblenda gnaisses rosados leucocráticos de composição granítica a quartzo-sienítica e estrutura fortemente lineada, biotitahornblenda gnaisses rosados leucocráticos de composição granítica e gnaisses quartzo-sieníticos a monzograníticos hololeucocráticos. Associam-se através de 
contatos difusos (Figura 6.3.A) a rochas cinza-escuras a esverdeadas granulíticas de composições mangeríticas a charnockíticas.

\section{Hornblenda gnaisses lineados}

Os hornblenda gnaisses rosados leucocráticos de composições graníticas a quartzo-sieníticas são inequigranulares de granulação grossa com porfiroclastos de feldpato alcalino e de hornblenda. Apresentam uma foliação milonítica que, localmente, passa a bandas centimétricas (ca. $7 \mathrm{~cm}$ de espessura) ultramiloníticas (Figura 6.3.B). Associada a essa foliação, ocorre forte lineação de estiramento mineral marcada por feldspato alcalino, hornblenda e algum quartzo (Figura 6.3.C). Enclaves de hornblenda quartzo-sienitos também ocorrem em rochas granulíticas (Figura 6.3.E).

A foliação milonítica se desenvolve com texturas gerais nemato-lepidogranoblásticas com porfiroclastos de feldspato e hornblenda. Cristais de quartzo e feldspato se distribuem em uma matriz granoblástica inequigranular seriada fina a média interlobada com rotação de subgrãos e alguns cristais poligonizados. Cristais de quartzo ainda desenvolvem ribbons recristalizados, com contatos serrilhados internos com cerca de 0,2 $\mathrm{mm}$ de espessura. Os ribbons recristalizados apresentam uma fábrica de forma interna oblíqua à foliação da rocha, denotando uma disposição S/C. Localmente eles também amoldam porfiroclastos. Nas porções mais finas da matriz, principalmente onde começa a se desenvolver uma fábrica poligonal com extinção ondulante, há pequenos filmes com continuidade óptica através das bordas dos grãos (Prancha III.E). Outra microestrutura de fusão pode ser exemplificada por pseudomorfos de fusão de plagioclásio com terminações em cúspide (Prancha III.A).

A biotita ( 1\% modal), de pleocroísmo castanho a vermelho, junto com cristais finos e idioblásticos de hornblenda castanha a verde ( 6-7\% modal), definem as porções nemato-lepidoblásticas dispostas de forma anastomosada amoldando porfiroclastos ou em pares S/C, além de algumas formas em fish de hornblenda. Bandas extensionais do tipo C' são marcadas por biotita e minerais opacos. Cristais de clinopiroxênio ( $5 \%$ modal) reliquiares podem ocorrer na matriz em contato com hornblenda e plagioclásio (Prancha III.A). Actinolita também é descrita localmente em texturas coroníticas envolvendo cristais de quartzo (Prancha III.B). Minerais acessórios são monazita, alanita, apatita e opacos. 
Os porfiroclastos de hornblenda, que chegam a ser centimétricos, de pleocroísmo castanho a verde escuro, apresentam bordas arredondadas e terminações sigmoidais, contendo constantes inclusões de opacos, biotita, quartzo e plagioclásio, estes dois últimos, goticulares. São constantes porfiroclastos do tipo dominó (Prancha III.C), sendo que alguns chegam a desenvolver fraturas preenchidas pelo mesmo material quartzo-feldspático da matriz. Em algumas porções marginais, os porfiroclastos de hornblenda são manteados por uma recristalização estática em textura poligonizada.

Os porfiroclastos de feldspato, principalmente pertíticos a mesopertíticos, apresentam-se deformados plasticamente em assimetrias do tipo delta a sigmoidais com bordas recristalizadas a grãos menores de quartzo, plagioclásio e feldspato alcalino poligonais. São comuns ainda, intercrescimentos mirmequíticos nas bordas dos porfiroclastos de feldspato. Alguns megacristais tanto de plagioclásio como de feldspato alcalino, de caráter porfiroclástico, preservam faces ígneas e inclusões de feldspatos subeuhédricos tabulares. Apresentam um caráter deformacional distinto, mais rúptil, de forma que apresentam fraturas preenchidas por quartzo (Prancha III.D).

\section{Biotita-hornblenda gnaisses graníticos}

Além de fazerem contatos difusos com rochas granulíticas, os biotitahornblenda gnaisses graníticos apresentam estruturas migmatíticas em grade (estrutura agmatítica), de forma que as vênulas alimentam um bolsão onde o biotitahornblenda gnaisse é coletado (Figura 6.3.D).

São rochas rosadas leucocráticas de composição granítica com uma maior porcentagem modal de biotita e hornblenda em relação aos gnaisses lineados e apresentam granulação fina a média. Dentre os minerais acessórios, ocorrem apatita, opacos e titanita.

Predominam texturas granoblásticas quartzo-feldspáticas inequigranulares seriadas com contatos interlobados a poligonizados. São muito comuns porfiroclastos de feldspatos pertíticos e alguns antipertíticos. Ribbons de quartzo recristalizados ocorrem segundo a foliação da rocha, por vezes dobrados de forma assimétrica com comprimentos de onda de $0,2 \mathrm{~mm}$, e por vezes com uma fábrica de forma interna oblíqua à foliação, denotando uma estrutura S/C. 

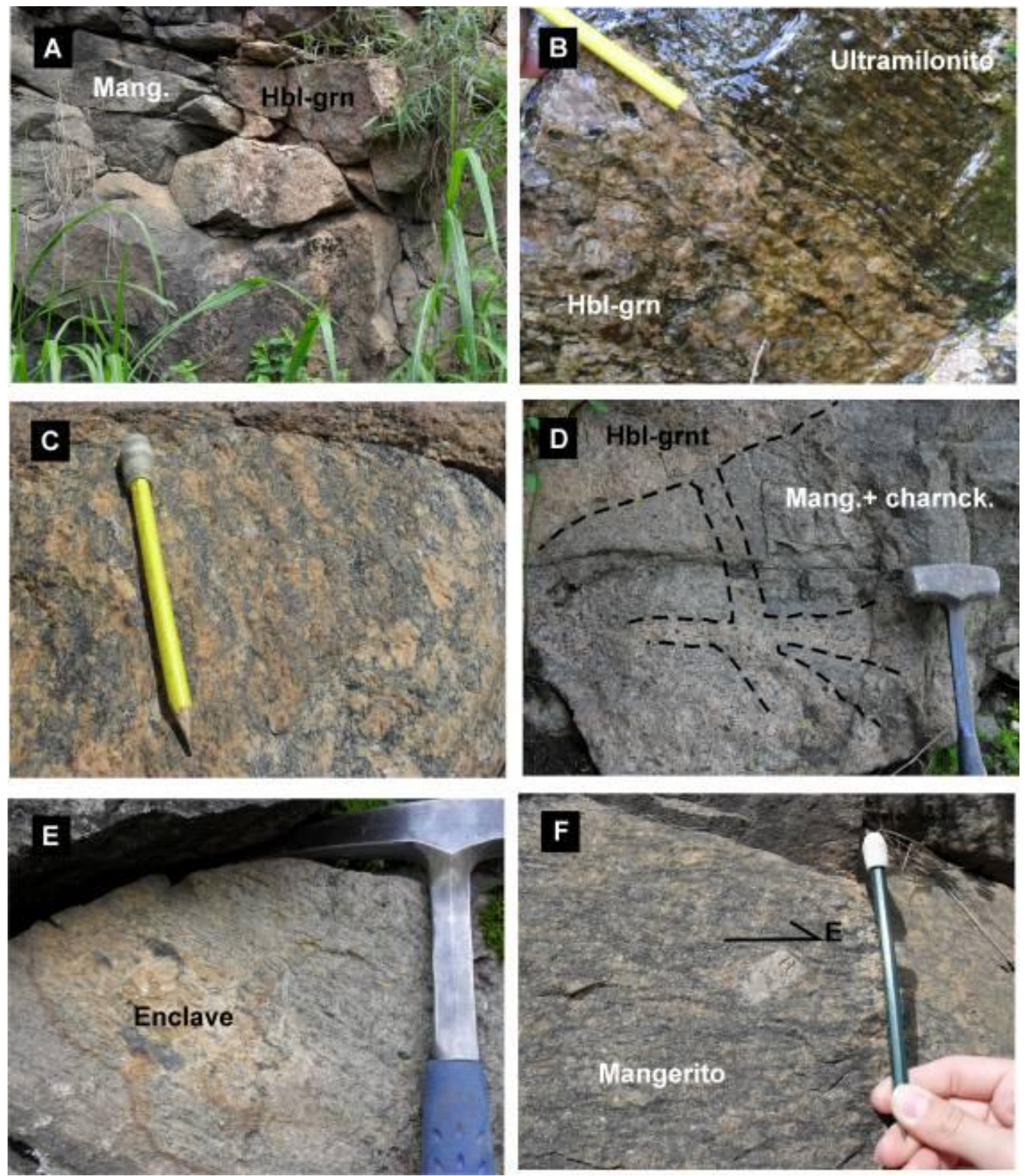

Figura 6. 3 - (A) Contato difuso entre hornblenda-granitóides (hbl-grn) rosados e rochas mais escuras de cor cinza a esverdeada mangeríticas (Mang). O lado maior da foto indica cerca de 3 metros; (B) Hornblenda gnaisse (Hbl-grn) milonítico passando a faixas ultramiloníticas com cerca de $7 \mathrm{~cm}$ de espessura ; (C) Lineação de estiramento mineral marcada por hornblenda e feldspato alcalino; (D) Estrutura migmatítica em grade de biotitahornblenda granitóides rosados em rochas mangeríticas e charnoquíticas. Observar, na porção superior da foto, um bolsão onde o hornblenda-granitóide é coletado; (E) Enclave, com eixo maior de $10 \mathrm{~cm}$, de hornblenda quartzo-sienitos em rochas charnoquíticas; (F) Rocha mangerítica com fenocristal de feldspato alcalino subeuhédrico, porém com bordas recristalizadas em sigma (i.e. profiroclasto) indicando movimentação de topo para E.

Biotita com pleocroísmo castanho a avermelhado e cristais de hornblenda com pleocroísmo castanho a verde de granulação fina definem uma foliação que por vezes está organizada em S/C. São muito comuns porfiroblastos de hornblenda, de granulação média a grossa, idioblásticos e tabulares ricos em inclusões de biotita, quartzo goticular e minerais opacos. 
Microestruturas de fusão são muito comuns com topologias em filmes, além de pequenas "piscinas" de fundido com terminações em cúspide e contendo cristais de quartzo subeuhédricos hexagonais. Tais melt pools estão pseudomorfizados por feldspato (Prancha III.F).

\section{Gnaisses quartzo-sieníticos hololeucocráticos}

São rochas rosadas hololeucocráticas de granulação fina a média gnáissicas de composição quartzo-sienítica a monzonítica. Cristais de biotita ( $2 \%$ modal) ocorrem dominantemente no contato entre os grãos de quartzo e feldspato e encontram-se cloritizadas. Cristais de clinopiroxênio $(<1 \%$ modal) ocorrem isolados. Ocorrem texturas granoblásticas inequigranulares interlobadas de granulação média a grossa, predominando feldspatos pertíticos e mesopertíticos. Texturas hipidiomórficas de granulação fina a média também são observadas com cristais subeuhédricos tabulares de feldspato alcalino e plagioclásio, os quais raramente estão geminados. Cristais de microclínio apresentam caráter intersticial, sendo observado ainda cristal de plagioclásio com núcleos sericitizados e bordas límpidas com padrão de extinção diferente do centro.

\section{As rochas charnockito-mangeríticas}

Em campo foram observados charnockitos e granulitos félsicos associados por meio de contatos difusos (Figura 6.3.A) aos hornblenda granitóides. Rochas mangeríticas com cristais de feldspato alcalino rosados podem ser resultado dessa interação difusa. Ocorrem também granulitos máficos cujas relações de contato não foram observadas em campo.

A mineralogia principal dos charnockitos e granulitos félsicos é composta por feldspato alcalino $(40 \%)$, quartzo $(20 \%)$, plagioclásio $(15 \%)$, clinopiroxênio $(10 \%)$, ortopiroxênio $(5 \%)$, hornblenda $(5 \%)$ e biotita (5\%). Minerais acessórios incluem actinolita, apatita, titanita, clorita e minerais opacos. A matriz dessas rochas apresenta uma textura fanerítica inequigranular média a grossa composta por cristais de feldspato ternário mesopertítico subeuhédricos e cristais de plagioclásio com geminações polissintéticas levemente deformadas (Prancha Illa.A). Os contatos entre os grãos são retilíneos preservando faces ígneas. Fenocristais de feldspato alcalino subeuhédricos apresentam pouca recristalização nas bordas, e não 
raramente apresentam inclusões subeuhédricas de plagioclásio. Os cristais de quartzo são os únicos com forte extinção ondulante e caráter intersticial entre os cristais e fenocristais de feldspato. São comuns intercrescimentos mirmequíticos. Nos granulitos, que gradam a composições mangeríticas, a textura passa a ser predominantemente granoblástica inequigranular média a grossa interlobada e porfiroclástica.

Os cristais de ortopiroxênio são granulares a prismáticos e apresentam pleocroísmo levemente esverdeado a castanho-rosado. Estão sempre associados à biotita, clinopiroxênio e minerais opacos. Localmente, apresentam estruturas coroníticas com o clinopiroxênio, e, quando mais granulares subidioblásticos, estão substituídos nas bordas por biotita. O clinopiroxênio apresenta pleocroísmo incolor a levemente esverdeado, geralmente em formas granulares com clivagens bem acentuadas e possíveis micro-exsoluções. Associam-se a minerais opacos e biotitas fortemente avermelhadas, e são substituídos nas bordas por hornblenda. Quando não apresentam micro-exsoluções, os cristais estão substituídos nas bordas por actinolita fibrosa. Cristais triangulares com terminações em cúspide de quartzo ao redor de cristais de ortopiroxênio (Prancha Illa.A), simplectitos de plagioclásio com biotita avermelhada e bolsões com terminações em cúspide a arredondadas pseudomorfizado por plagioclásio com inclusões de quartzo (Prancha IIla.B), são microestruturas de fusão parcial.

Dentre as composições máficas, ocorrem hornblenda-clinopiroxênio granulitos diatexíticos de composição charnoquítica a mangerítica e cores cinza clara a levemente rosados com enclaves dobrados de hornblenda-clinopiroxênio granulitos charno-enderbíticos cinza escuros (Figura 6.4.A), que sugestivamente representam o paleossoma. Este, em lâmina delgada, apresenta matriz granoblástica inequigranular média poligonal a interlobada. Predominam cristais poligonais e com extinção ondulante de oligoclásio, localmente interlobados e porfiroclásticos. O feldspato alcalino é microclíneo, intersticial. O quartzo é interlobado e fortemente ondulante. A hornblenda, castanha a verde, ocorre idioblástica e marca uma foliação. Ocorrem associadas ao plagioclásio e ao ortopiroxênio, podendo estar substituídas nas bordas por biotita avermelhada. O ortopiroxênio apresenta inclusões de clinopiroxênio. 

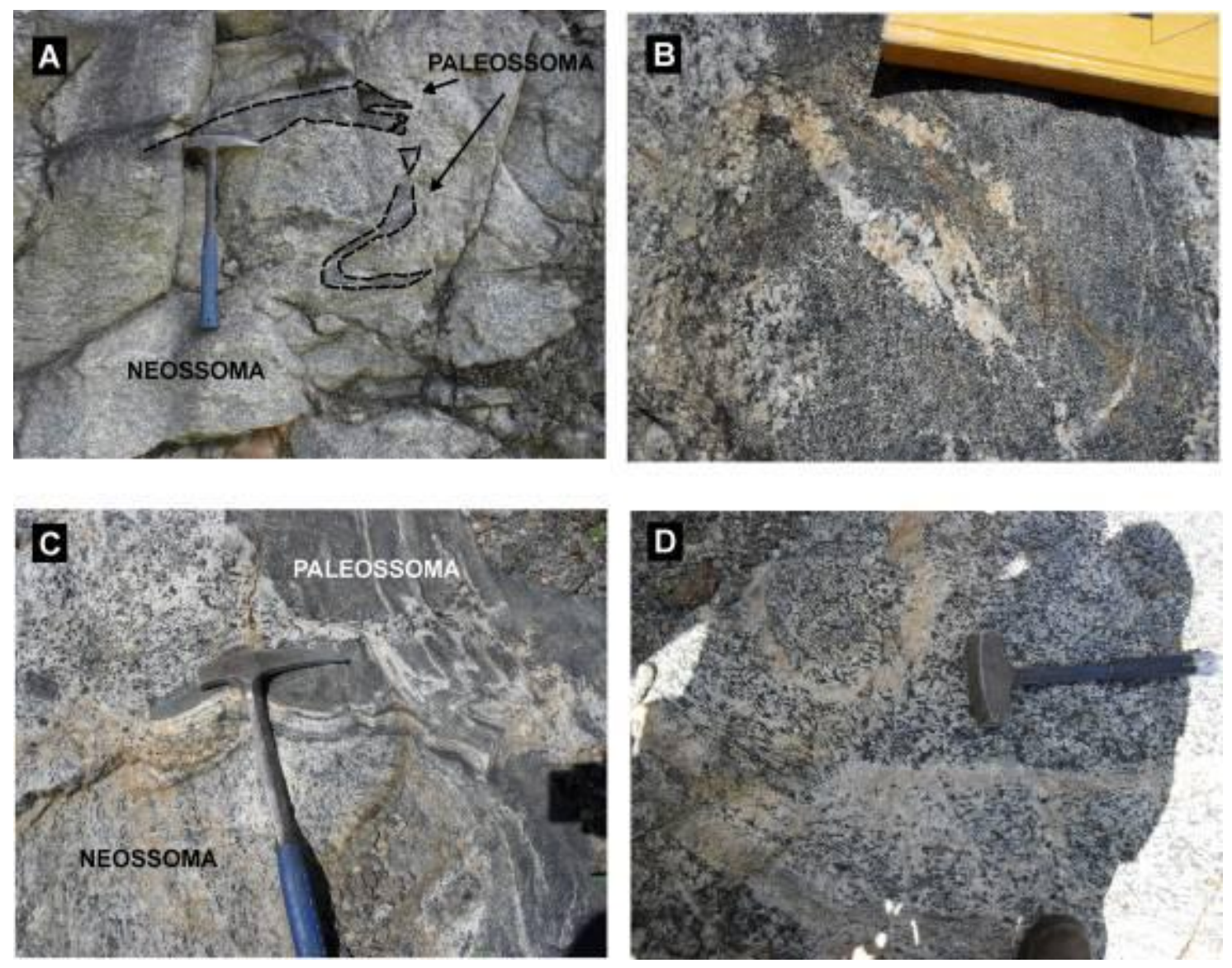

Figura 6. 4 - (A) Hbl-Cpx granulito mangerítico diatexítico (neossoma) com enclave dobrado de $\mathrm{Hbl-Cpx}$ granulito charno-enderbítico (paleossoma); (B) Estrutura do tipo patch-migmatite com a geração de neossoma quartzo monzonítico hololeucocrático; (C) Quartzo-monzonitos diatexíticos com provável início de fusão de caráter estromático acompanhando a foliação do paleossoma até alimentar bolsões ricos em neossoma contendo pequenos enclaves do paleossoma; (D) Variação do diatexito quartzo-monzonítico rico em porfiroblastos de feldspato e hornblenda.

Os granulitos diatexíticos em lâmina delgada, apresentam matriz granoblástica inequigranular média a grossa interlobada a poligonal, onde predominam cristais de plagioclásio com geminações polissintéticas deformadas e cristais de microclínio, além de alguns poucos cristais ternários pertíticos e antipertíticos. Um ou outro cristal de plagioclásio apresenta-se subeuhédrico com faces ígneas. A hornblenda, verde a castanha e idioblástica, marca uma foliação paralela à orientação preferencial dos cristais alongados de quartzo. Cristais grossos e granulares de ortopiroxênio (Prancha Illa.C) apresentam bordas substituídas por clinopiroxênio que grada para uma fina película de hornblenda. Cristais de biotita são dominantemente tardios, com pleocroísmo castanho a vermelho, por vezes substituindo nas bordas cristais de ortopiroxênio (Prancha Illa.F). Filmes de quartzo e plagioclásio correspondem aos principais pseudomorfos de fusão (Prancha Illa.E).

Além dos diatexitos charnoquíticos a mangeríticos, ocorrem rochas hololeucocráticas brancas de composição quartzo-monzonítica e caráter diatexítico. 
Estas ocorrem, localmente, como estruturas do tipo patch-migmatite sobre um paleossoma cinza-escuro e foliado (Figura 6.4.B). Vênulas e bandas paralelas de leucossoma ocorrem na foliação desse paleossoma, de onde interconectam-se e alimentam bolsões diatexíticos (Figura 6.4.C). Esses diatexitos podem gradar a fácies hololeucocráticos de composição leucodiorítica a hornblenda e plagioclásio porfiroblásticos (Figura 6.4.D).

Em lâmina delgada, esses diatexitos possuem uma textura fanerítica média a grossa inequigranular com fenocristais alongados de andesina bem facetados (prancha Illa.F). A matriz, localmente granoblástica fina e interlobada, compreende oligoclásio, microclínio e quartzo, todos com extinção ondulante. Na matriz ainda ocorrem antipertitas e intercrescimentos mirmequíticos. Os cristais de horblenda são idioblásticos e chegam a desenvolver domínios granoblásticos de recristalização estática, sendo comuns inclusões de quartzo e apatita. Algumas podem aparecer como inclusões em cristais de plagioclásio. Está fortemente substituída por cristais de biotita avermelhados. Observa-se também cristais de plagioclásio com terminações em cúspide como pseudomorfos de fusão. 


\section{Prancha II - Suite Granito-Migmatítica Pinhal}
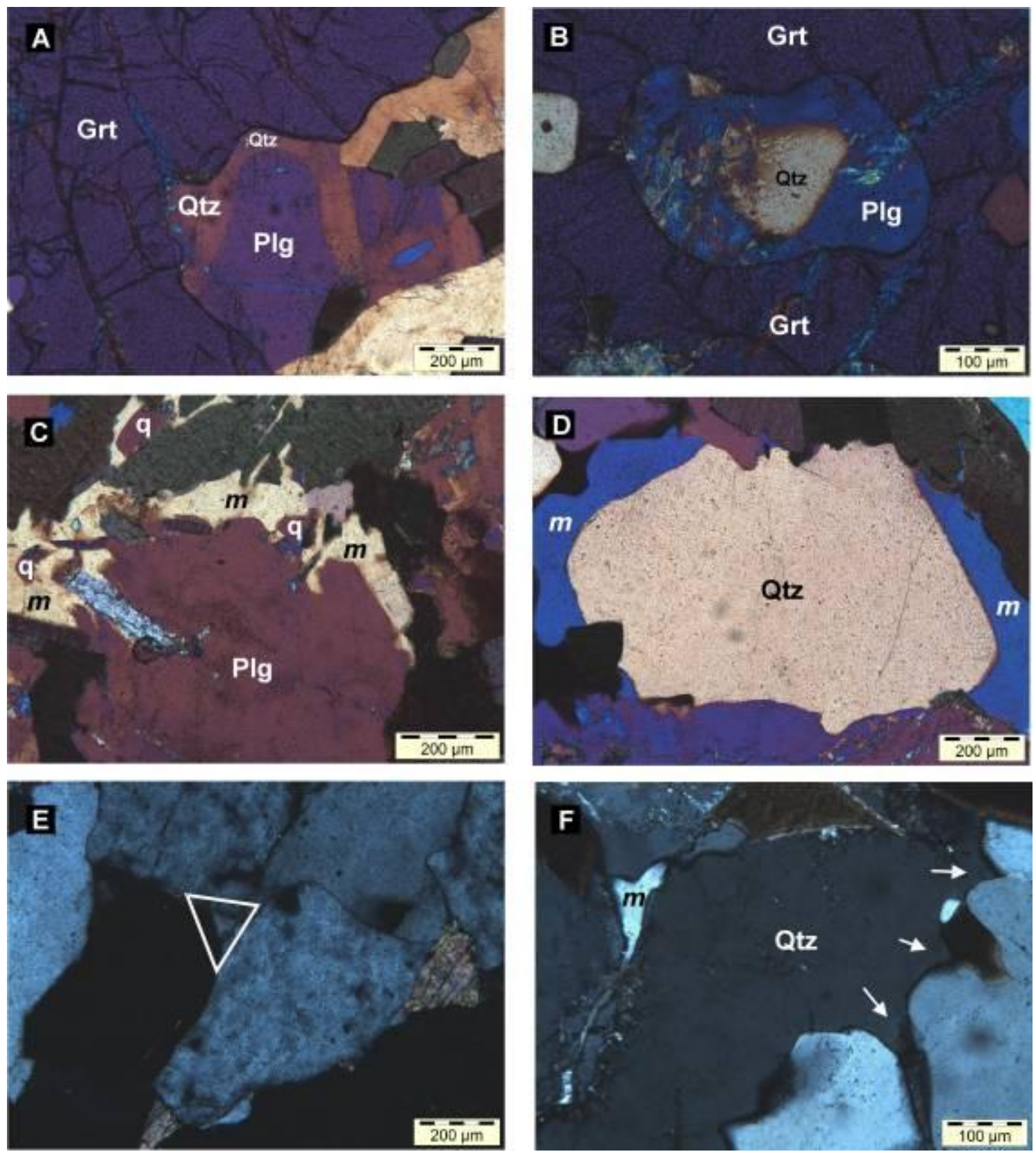

Prancha II - (A) No centro da foto ocorre um filme de quartzo como pseudomorfo de fusão. Sua topologia está controlada pelas bordas dos cristais de granada e de plagioclásio, definindo um ângulo dihedral igual ou maior do que $60^{\circ}$; (B) Inclusão em cristal de granada em forma de gota pseudomorfizado por plagioclásio e quartzo; (C) Bolsão de líquido de fusão $(m)$ pseudomorfizado por plagioclásio contendo pequenos cristais de quartzo subeuhédricos. A cor amarela do bolsão indica sua continuidade óptica; (D) Cristal de quartzo com bordas contendo líquido de fusão $(m)$ pseudomorfizado por quartzo. A cor azul indica sua continuidade óptica. Ângulos diherdrais são menores do que $60^{\circ}$; (E) Início de fusão parcial em junções tríplices (destacada pelo triângulo branco); (F) No centro da foto observa-se cristal de quartzo com terminações em cúspide (indicado pelas flechas brancas) com ângulos dihedrais iguais ou menores do que $60^{\circ}$. Na porão centro-esquerda da foto ocorre líquido de fusão $(m)$ pseudomorfizado por quartzo como topologia triangular, terminações em cúspide e ângulos dihedrais menores do que $60^{\circ}$. O pequeno canalículo abaixo dessa microestrutura indica a variação entre topologias triangulares em cúspide para filmes ao longo das bordas dos grãos. 


\section{Prancha III - Suite Granito-Charnoquítica São José do Rio Pardo}
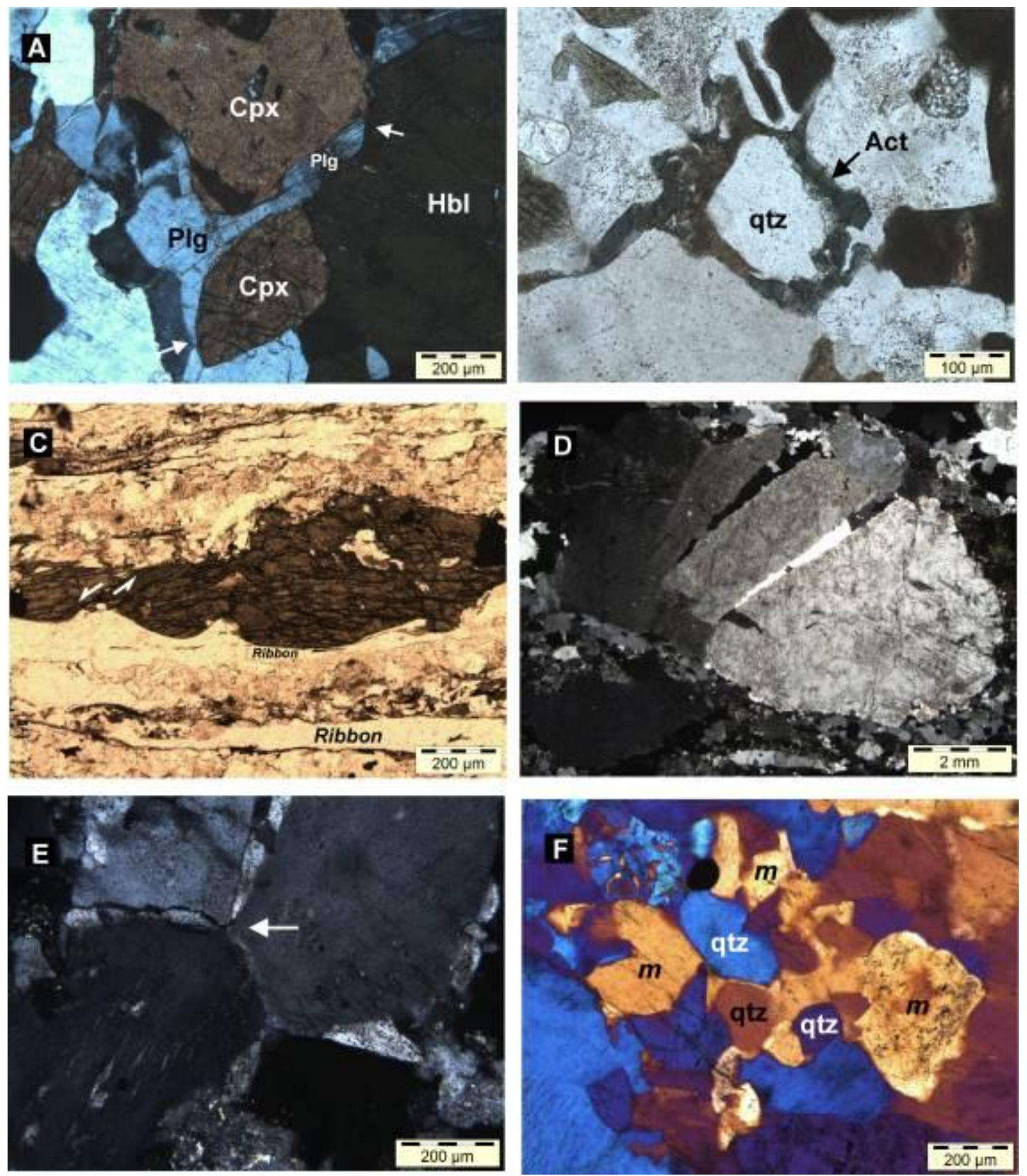

Prancha III - (A) Cristais de clinopiroxênio (Augita) com hornblenda. Observar cristal de plagioclásio como pseudomofo de fusão e ângulos dihedrais indicados pelas flechas brancas; (B) Textura coronítica de actinolita ao redor de cristal de quartzo; (C) Porfiroclasto em dominó de hornblenda. Movimentação está indicada pelas flechas na figura; (D) Porfiroclasto de feldspato alcalino com extinção ondulante e fraturas preenchidas pelo mesmo material da matriz; (E) Flecha branca indica junção tríplice a partir do qual se formaram filmes de líquido de fusão pseudomorfizados por plagioclásio; (F) Bolsão com terminações em cúspide de líquido de fusão $(m)$ pseudomorfizado por plagioclásio contendo alguns cristais subeuhédricos de quartzo e intercrescimentos mirmequíticos. Observar variação nos ângulos dihedrais. 


\section{Prancha Illa - Suite Granito-Charnoquítica São José do Rio Pardo}
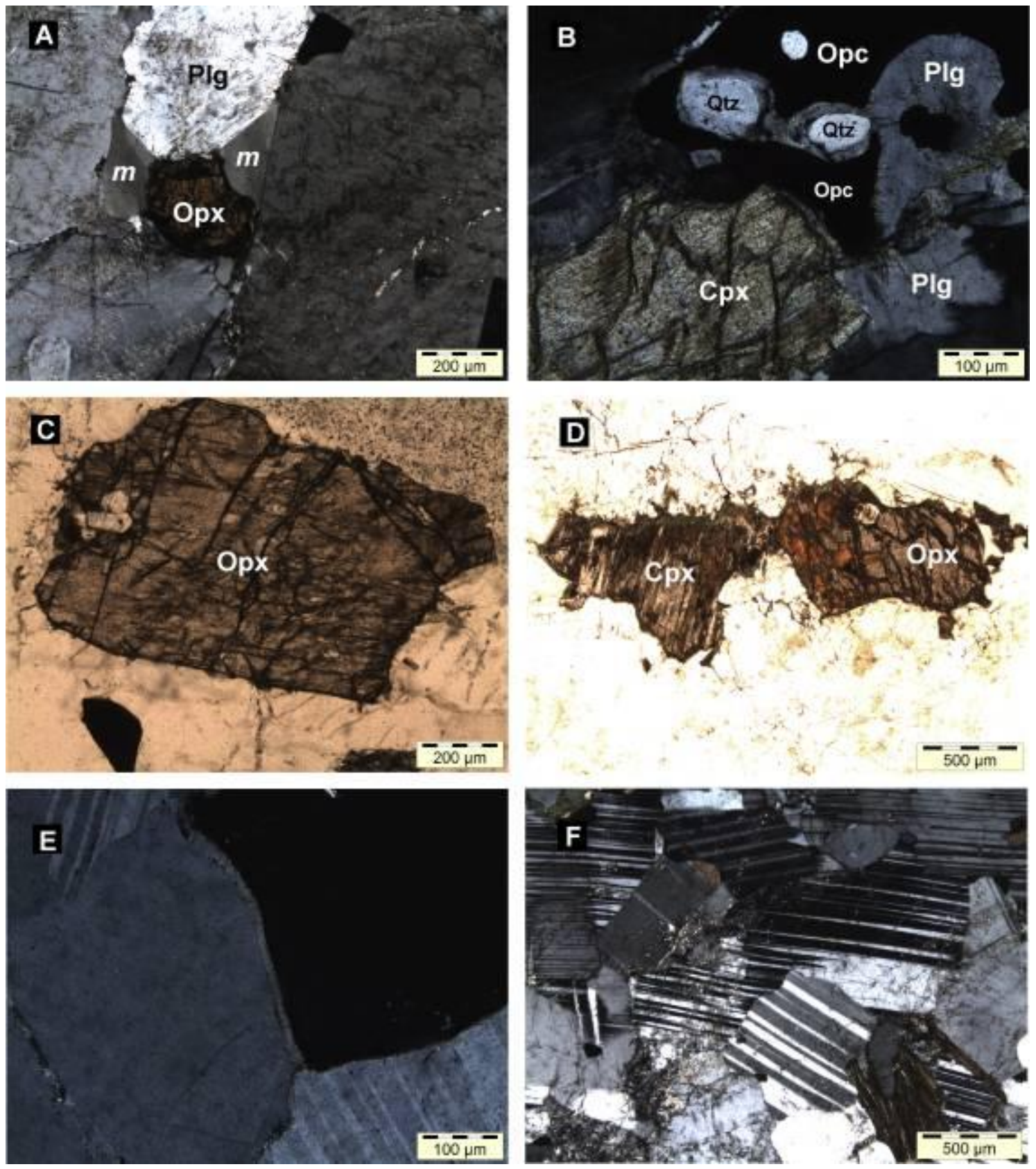

Prancha Illa - (A) Líquido de fusão $(m)$ pseudomorfizado por quartzo em formatos triangulares e com terminações em cúspide e ângulos dihedrais $\leq 60^{\circ}$; (B) Cristal de mineral opaco (Opc) xenoblástico com inclusões de plagioclásio contendo cristais subarredondados de quartzo pseudomorfizando bolsão de líquido de fusão; (C) Cristal bem formado de ortopiroxênio em matriz quartzo feldspática; (D) Cristais de orto e clinopiroxênio em paragênese. Notar que o cpx tem alteração nas bordas para hornblenda enquanto que o opx é também substituido por biotita; (E) Pseudomorfo de fusão de plagioclásio com topoliga em filme; (F) Textura fanerítica média a grossa inequigranular em quartzo-monzonitos com hornblenda. 


\subsection{Unidade Metatexítica}

Geograficamente, as rochas da Unidade Metatexítica Superior ocupam a porção norte da Folha Caconde, nordeste da Folha São José do Rio Pardo e sudeste-sudoeste da Folha Guaranésia. Os principais litotipos foram agrupados no Complexo Metamórfico Caconde.

\subsubsection{Complexo Metamórfico Caconde - Sequência Metassedimentar}

Rochas fortemente alteradas apresentam um bandamento composicional fino. Este bandamento caracteriza-se pela intercalação de camadas finas vermelhoescuras em camadas um pouco mais espessas com tons vermelhos mais claros e que parecem preservar uma antiga foliação metamórfica ou uma estrutura gnáissica. Além disso, ocorrem porções sem continuidade lateral de granulação mais grossa e cores brancas a rosadas, rica em quartzo e feldspatos caulinizados, colocam-se segundo o bandamento. A espessura dessas bandas é variável, podendo passar de $5 \mathrm{~cm}$ a $20 \mathrm{~cm}$ (Figura 6.5.A). Desenvolvem também, localmente, estruturas boudinadas. Tais rochas bandadas são, sugestivamente, biotita gnaisses metatexíticos, em que o neossoma apresentou segregação e gerou porções melanossomáticas e leucossomáticas, definindo um bandamento estromático paralelo à foliação da rocha.

Outras litologias, também alteradas, aparecem como enclaves sigmoidais (Figura 6.5.B) e enclaves equidimencionais rotacionados distribuídos em uma rocha com estrutura foliada. $\mathrm{O}$ dobramento dessa foliação ao redor dos enclaves indica uma interação plástica - ou talvez magmática - entre eles e a rocha hospedeira. Existem padrões de alteração distintos entre a rocha hospedeira, sendo que os enclaves sigmoidais apresentam cores roxas, os enclaves equidimensionais cores ocres e a rocha hospedeira apresenta coloração vermelho clara, semelhantes aos metatexitos estromáticos.

Localmente também foram descritos afloramentos com quartzitos e quartzitos feldspáticos de granulação média, foliadas e com lineações de quartzo. Associam-se a elas, rochas calciossilicáticas com estrutura bandada e textura granoblástica. Intercalam-se bandas ricas em feldspato, quartzo e fluorita com bandas ricas em piroxênio, anfibólio e biotita. 

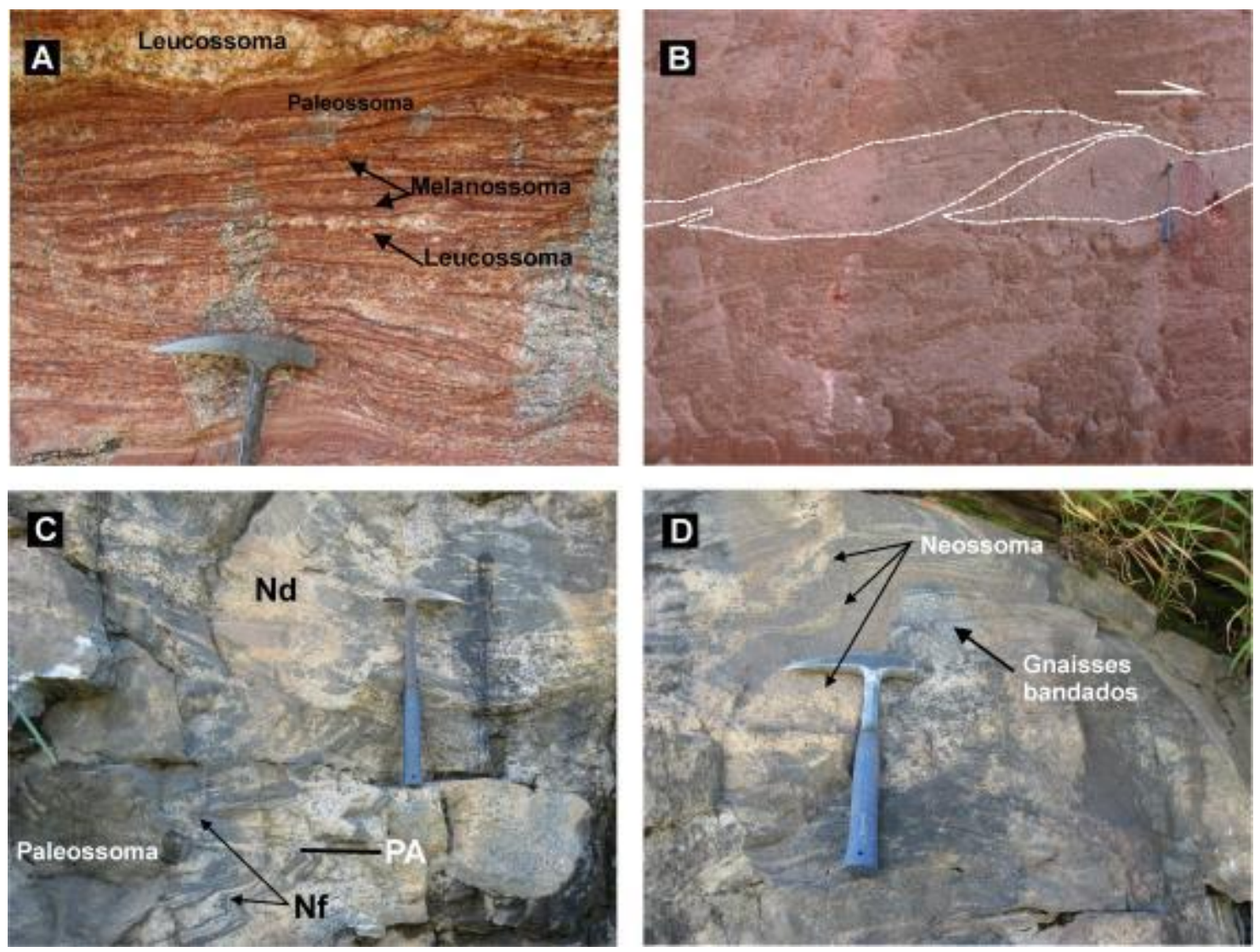

Figura 6.5 - (A) Migmatito estromático alterado com bandamento composicional fino. O leucossoma é marcado por bandas brancas quartzo-feldspáticas grossas enquanto que o melanossoma, nem sempre na interface neossoma/paleossoma, apresenta-se como finas bandas vermelho escuras. O paleossoma apresenta cores vermelhas um pouco mais claras e preserva uma foliação. Notar que o leucossoma e o melanossoma colocamse paralelamente à foliação. (B) Enclaves sigmoidais com indicação de topo para NW. Apresentam cores de alteração roxas e estão em rocha alterada bandada com cores de alteração vermelho claras; (C) Unidade dos gnaisses migmatíticos. Observar que ocorre neossoma leucocrático branco dobrado junto com a foliação e colocado no plano axial (PA). Nas porções dilatantes (Nd), o neossoma apresenta estrutura maciça e nas porções dobradas (Nf), ele está foliado. O paleossoma é de rocha cinza escura foliada e dobrada; (D) Gnaisses com bandamento composicional bandado associados a neossomas leucocráticos brancos com cristais centimétricos de hornblenda.

\subsubsection{Complexo Metamórfico Caconde - Gnaisses migmatíticos}

Três associações migmatíticas foram descritas nessa unidade. A primeira apresenta paleossoma de hornblenda gnaisses cinza-escuros bandados com foliação dobrada, e neossoma de rochas leucocráticas monzo-dioríticas inequigranulares de granulação média-grossa. Ocorre na foliação do paleossoma onde delineia seu dobramento e injeta-se no plano-axial, ou ocorre como vênulas injetadas em zonas dilatantes (Figura 6.5.C).

O paleossoma tem composição monzogranítica em que quartzo (25\%), plagioclásio (30\%) e feldspato alcalino (15\%) desenvolvem uma matriz granoblástica inequigranular interlobada a serrilhada. Todos apresentam extinção ondulante e a geminação polissintética do plagioclásio está fortemente deformada, por vezes, 
terminando em cunha. Hornblenda (25\%), com pleocroísmo verde escuro a castanho, desenvolve uma textura nematoblástica e define a foliação da rocha. Ocorre substituída nas bordas por cristais de biotita (5\%) avermelhados que não chegam a orientar-se segundo a foliação. A mineralogia acessória é composta por apatita, opacos e clorita, esta última, substituindo a biotita. Pseudomorfo de fusão com terminações em cúspide e ângulos dihedrais $<60^{\circ}$ ocorrem entre cristais de hornblenda e plagioclásio (Prancha IV.A).

O neossoma é um biotita-hornblenda granodiorito e apresenta uma textura geral fanerítica inequigranular média a grossa. Os cristais de felspato, andesina e pertitas, ocorrem subeuhédricos e com leve extinção ondulante. $O$ quartzo, intersticial entre as faces bem formadas dos feldspatos, apresenta-se com extinção ondulante, por vezes, em tabuleiro de xadrez. Hornblenda e biotita são os principais minerais máficos, os quais não apresentam-se orientados. A biotita é, dominantemente, de substituição da hornblenda. Localmente observa-se simplectitos de hornblenda e quartzo. Os minerais acessórios compreendem titanita, opacos e zircão. Os cristais de zircão dividem-se em duas populações, uma com hábito prismático bipiramidal como inclusões na hornblenda e na biotita, e outra com hábito granular equidimensional presente na matriz em associação com plagioclásio e apatita.

A segunda associação migmatítica apresenta como paleossoma um gnaisse cinza a cinza-escuro com bandamento composicional (Figura 6.5.D), e neossoma leucocrático com fenocristais de hornblenda. O bandamento composicional do paleossoma é caracterizado por porções cinzas, dominantes, de biotita-hornblenda gnaisses granodioríticos grano-nematoblásticos de granulação fina a média, e porções leucocráticas de gnaisses tonalíticos granoblásticos inequigranulares e interlobados de granulação fina a média. Nessas porções, a hornblenda, idioblástica, ocorre com menos de 5\%. Nessas porções ocorrem pseudomorfos de fusão com terminações em cúspide e ângulos dihedrais $<60^{\circ}$ (Prancha IV.B).

O neossoma associado aos gnaisses bandados é um clinopiroxênio charnoenderbito. Em lâmina delgada, apresentam uma textura hipidiomórfica fanerítica média a grossa em que cristais euhédricos de plagioclásio sem extinção ondulante dominam. Ocorrem cristais de quartzo e microclínio com leve extinção ondulante. Não raros são os intercrescimentos mirmequíticos. O clinopiroxênio é o principal mineral máfico, ocorrendo subeuhédrico com pleocroísmo incolor a levemente amarelado. Apresentam micro-exsoluções segundo a direção da clivagem e, nas 
bordas, são substituídos por cloritas e minerais opacos (Prancha IV.C). Localmente foram observadas inclusões euhédricas de plagioclásio (Prancha IV.D). Os cristais de ortopiroxênio são mais finos. Nessas rochas são comuns microestruturas de fusão em filmes e com topologias triangulares em cúspide.

Finalmente, a terceira associação migmatítica tem clinopiroxênio-hornblenda gnaisses mangeríticos como paleossomas. Em lâmina delgada, observa-se um bandamento composicional em que se alternam bandas quartzo-feldspáticas intercaladas com porções ricas em hornblenda. A matriz apresenta-se granoblástica inequigranular fina a média interlobada com geração de subgrãos. Cristais menores de plagioclásio, recristalizados, são andesina, enquanto que os mais grossos são labradorita. Nessa matriz, são comuns feições triangulares em cúspide e filmes de fusão. A hornblenda, nematoblástica e definindo a foliação, é fina a média, idioblástica e está sempre associada, nas bordas, a cristais de biotita avermelhados e retrógrados. Os cristais de clinopiroxênio são substituidos pela hornblenda da matriz e pela biotita, sempre associado a minerais opacos. O ortopiroxênio ocorre na matriz granoblástica subidioblástico e com uma fina camada de anfibólio nas bordas (Prancha IV.E). Os principais minerais acessórios são apatita, aciculares finas a prismáticas grossas, e cristais de zircão subarredondados associados à apatita (como inclusões) e mais grossos e prismáticos na matriz.

O neossoma associado apresenta hornblenda-biotita quartzo-monzodioritos em textura fanerítica inequigranular média a grossa. Predominam cristais grossos e idiomórficos de antipertita, ocorrendo também pertitas, mesopertitas e algum microclínio. Intercrescimento mirmequíticos são abundantes e ocorrem como bolsões com terminações retilíneas contra as faces dos cristais de feldspato. $O$ quartzo ocorre exclusivamente com feições triangulares em cúspide (Prancha IV.F) contra as faces ígneas dos feldspatos, sem apresentar extinção ondulante. Os cristais de hornblenda não apresentam orientação preferencial e estão sempre substituídos por biotita nas bordas e por meio das clivagens. 


\section{Prancha IV - Complexo Caconde}
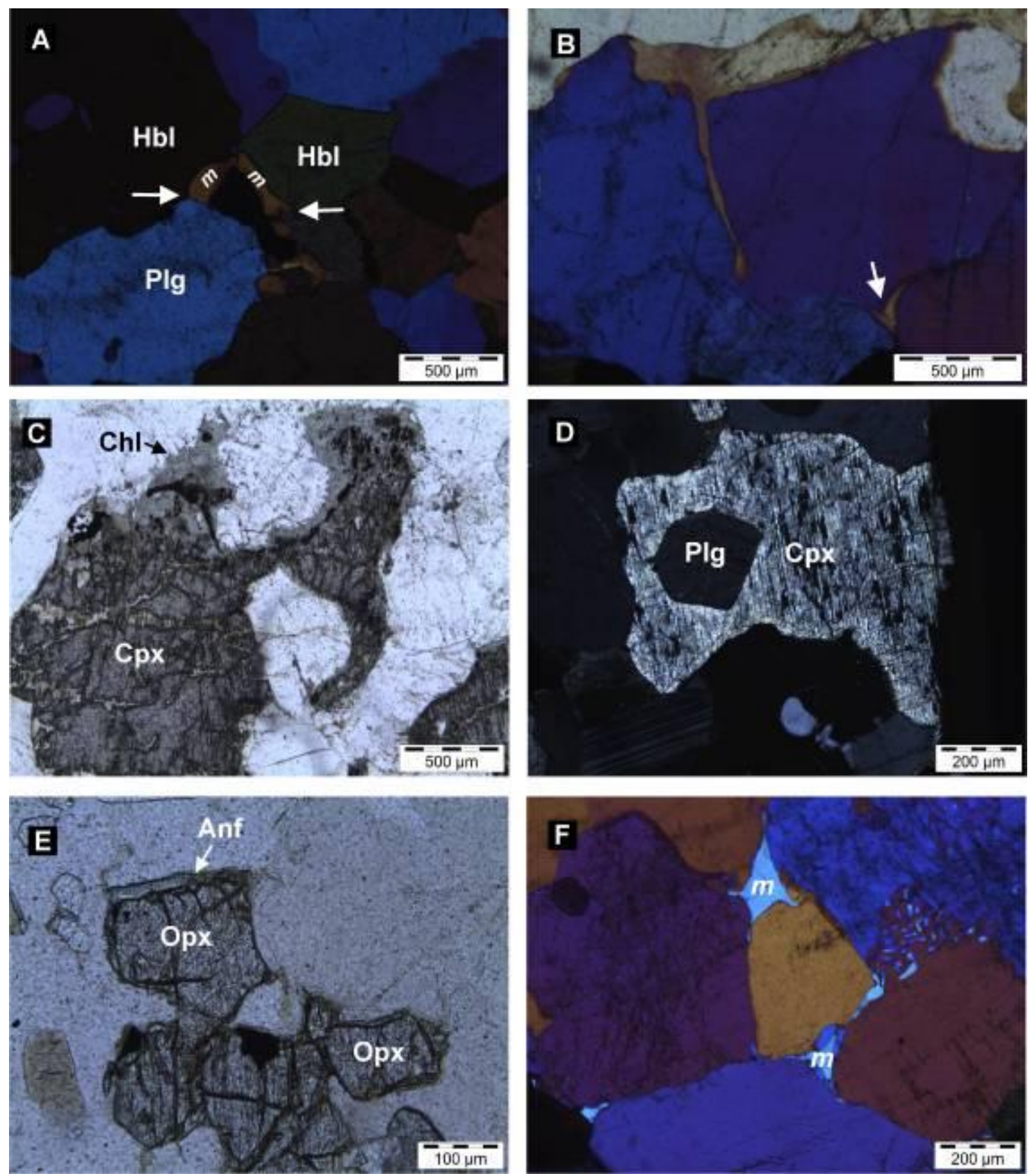

Pancha IV - (A) pseudomorfo de fusão $(m)$ entre cristais de hornblenda, plagioclásio e opaco. A seta branca da direita indica ângulo dihedral $<60^{\circ}$ entre 0 fundido e dois cristais de hornblenda. A seta da esquerda indica ângulo dihedral $>60^{\circ}$ entre o fundido, a hornblenda e o plagioclásio; (B) No centro da foto, filme de quartzo como pseudomordo de fusão. A seta branca indica início de fusão em junção tríplice, gerando pseudomorfo de fusão triangular com terminações em cúspide e ângulos dihedrais $<60^{\circ} ;$ (C) Cristal subeuhédrico de clinopiroxênio sendo substituido nas bordas por clorita e minerais opacos; (D) Cristal de clinopiroxênio com micro-exsoluções segundo as clivagens. Observas inclusão de plagioclásio subeuhédrico; $(E)$ Cristal de ortopiroxênio com substituição de finas películas de anfibólio nas bordas; $(F)$ Pseudomorfos de fusão $(m)$, na parte superior, quadrangular com terminações em cúspide e início de geração de filmes. Abaixo, ocorre pseudomorfo triangular é cúspide. Todos apresentam ângulos dihedrais $<60^{\circ}$. 


\section{CAPÍTULO 7}

\section{GEOLOGIA ESTRUTURAL}

A principal estrutura planar descrita na área de estudo é uma foliação metamórfica primária $\left(S_{1}\right)$ que afeta todas as unidades litológicas. A geração dessa estrutura está ligada a um evento de alta temperatura sob condições de cisalhamento coaxial e não-coaxial, desenvolvendo elementos estruturais simétricos e assimétricos, além de diferentes lineações minerais associadas. Eventos deformacionais posteriores à geração dessas estruturas dobraram a foliação $S_{1}$ bem como as lineações associadas.

\subsection{A foliação $S_{1}$ e os dobramentos posteriores}

Nas porções basais do Lobo Guaxupé, entre as cidades de Tapiratiba e Guaxupé, a foliação $S_{1}$ ocorre paralela ao bandamento composicional dos granulitos, ora marcada por uma orientação de fábrica de forma de cristais de quartzo e feldspato, ora pela orientação de cristais idioblásticos tabulares de hornblenda (Prancha I.A e I.E). Nos clinopiroxênio-hornblenda gnaisses a foliação é marcada pela intercalação de cristais de hornblenda idioblásticos e tabulares orientados com porções quartzo-feldspáticas ricas em ribbons de quartzo de alta temperatura. O padrão deformacional desses granulitos admite um cisalhamento com forte componente coaxial, uma vez que dominam estruturas com padrões oblatos, como porfiroclastos simétricos do tipo $\Phi$ de feldspato alcalino e ribbons de quartzo, todos paralelos à foliação metamórfica e ao bandamento composicional. $\mathrm{O}$ desenvolvimento de substituições mirmequíticas nas bordas desses porfiroclastos indica temperaturas $\geq 600^{\circ} \mathrm{C}$ (e.g. Pryer, 1993 e Altenberger \& Wilhelm, 2000) e a geração de ribbons de quartzo, temperaturas acima de 500ㄷ (Stipp et al. 2002).

$\mathrm{Na}$ Unidade Diatexítica, entre as cidades de São Sebastião da Grama e São José do Rio Pardo, a foliação $S_{1}$ pode ocorrer paralela a bandamentos composicionais, como é o caso dos granada-biotita diatexitos schliere e schollen da suíte Pinhal, ou como uma foliação milonítica, como é o caso dos biotita diatexitos porfiroclásticos da suíte Pinhal e os hornblenda gnaisses lineados da suíte São José do Rio Pardo. A foliação milonítica apresenta caráter anastomosado e está associada aos porfiroclastos de feldspato alcalino e de hornblenda. Domina uma 
deformação não-coaxial com geração de importantes estruturas assimétricas, como porfiroclastos manteados assimétricos, porfiroclastos rotacionados e foliações com arranjo S/C'. A geração de ribbons de quartzo menos pronunciada mostra uma componente coaxial subordinada.

$\mathrm{Na}$ Unidade Metatexítica, no arredores da cidade de Caconde, a foliação $\mathrm{S}_{1}$ ocorre paralela ao bandamento composicional dos migmatitos estromáticos.

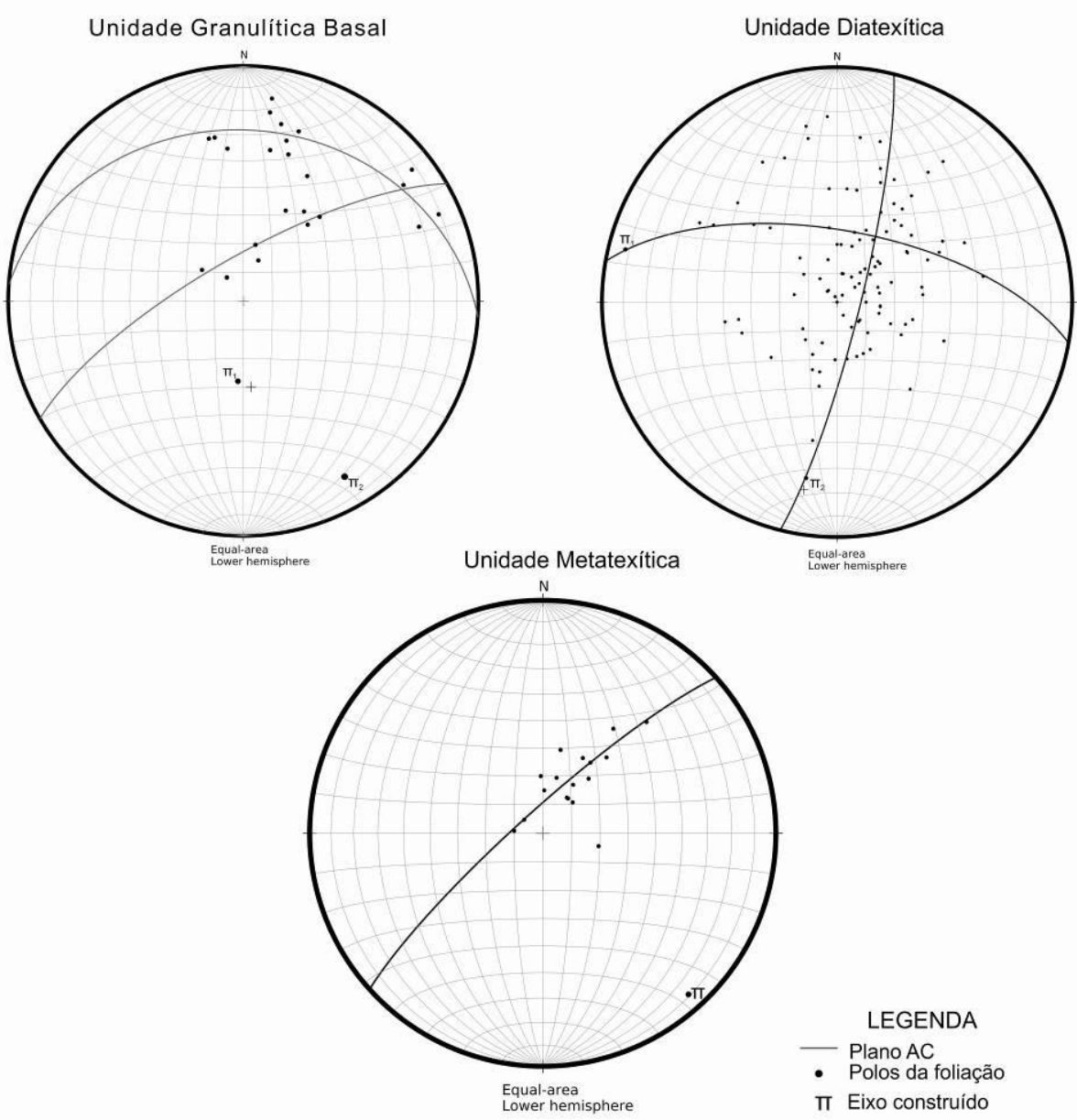

Figura 7 - Projeções estereográficas dos pólos da foliação $S_{1}$ para cada unidade litológica. As projeções ciclográficas são planos AC dos dobramentos posteriores. Notar que, para todas as unidades, a foliação tem uma direção preferencial NW-SE mergulhando para SW.

De acordo com a Figura 7, os dados estruturais da Unidade Granulítica Basal mostram que o padrão de dobramento axialmente orientado para sul e com forte caimento $\left(\pi_{1} 184^{\circ} / 64^{\circ}\right)$ é provavelmente posterior, dobrando flancos com forte mergulho das dobras orientadas SE ( $\left.\pi_{2} 160^{\circ} / 28^{\circ}\right)$ e com vergência para NE. Esse padrão é observado a norte da área representada no mapa (Anexo I), nos arredores da cidade de Guaxupé. A fase de dobramento que apresenta eixo axial de forte caimento deve estar associada à atividade da Zona de Cisalhamento Campo do Meio (Morales et al., 2005). 
A Unidade Metatexítica, no domínio do mapa, está deformada segundo as dobras orientadas SE ( $\left.\pi_{1} 152^{\circ} / 10^{\circ}\right)$. O padrão cilíndrico e o fraco caimento do eixo axial (Figura 7) sugerem a ausência de dobramentos anteriores.

De acordo com o mapa litoestrutural (Anexo I), a Unidade Diatexítica encontra-se colocada, por cavalgamento, acima da Unidade Metatexítica, na terminação periclinal de uma estrutura antiformal. Tal estrutura é definida por dobras parasitas, em escala de afloramento, que definem um padrão cilíndrico com eixo axial orientado E-W ( $\left.\pi_{1} 285^{\circ} / 5^{\circ}\right)$. Ainda nessa unidade, estão presentes dobras orientadas para $S$ (Figura 7), definindo um dobramento com eixo construído $\pi_{2}$ (190\%/24ํ) em um padrão aproximadamente cilíndrico. Entretanto, esse não é o único perfil de dispersão dessas dobras, de modo que também pode ser observado um padrão de dobramento cônico com uma geratriz de duplo caimento, indicando um padrão de superposição.

As dobras orientadas SE e com vergência para NE - destacadas na porção norte do mapa, a W de Tapiritiba (Campos Neto et al., 1988) - encontram-se no campo de esforço do cavalgamento da Unidade Diatexítica sobre a Unidade Metatexítica, provavelmente precedendo a megadobra E-W. Por fim, uma última fase de dobramento orientada N-S e N-NE afetou essas duas unidades na área de estudo, principalmente entre São Sebastião da Grama e São José do Rio Pardo (ver mapa).

\subsection{As lineações minerais e o transporte tectônico}

As lineações contidas na foliação $S_{1}$ são de diferentes naturezas, variando entre lineações de fluxo magmático, lineações de estiramento mineral e lineações de orientação mineral, todas paralela ao eixo cinemático $x$. A associação de cada tipo de lineação com seus indicadores cinemáticos indicam três direções principais de transporte tectônico, uma em estado subsólido e duas em estado sólido.

\subsubsection{Transporte sin-magmático}

O transporte em estado subsólido está orientado segundo lineações de fluxo magmático na direção NE-SW (Figura 7.1). Na Unidade Diatexítica, a NW da cidade de São Sebastião da Grama, ocorrem fenocristais de feldspato alcalino subeuhédricos não manteados orientados segundo a lineação $205^{\circ} / 20^{\circ}$. A 
orientação do eixo maior desses cristais paralela à foliação $S$ em que está contida $\mathrm{e}$ oblíqua à foliação C associada indica um transporte tectônico para NE (Figura 7.2.B). Esse transporte é também indicado por dobras assimétricas e desarmônicas sin-magmáticas sem foliação plano-axial (Figura 7.2.A). Na Unidade Metatexítica, ocorre um grupo de lineações de estiramento de quartzo com caimento de cerca de $20^{\circ}$ para SW. O transporte tectônico sin-magmático para NNE é evidenciado por enclaves de rochas anfibolíticas equidimensionais rotacionadas e foliações de fluxo magmático com arranjos S/C. Essas estruturas estão associadas ao mergulho preferencial da foliação principal para SW, indicando um transporte para NE com componente inversa.

\subsubsection{Transporte em estado sólido}

$\mathrm{Na}$ direção E-W, as lineações de estiramento de feldspato apresentam baixo ângulo de caimento para $\mathrm{S} 80^{\circ} \mathrm{E}$ e estão associadas a porfiroclastos manteados do tipo $\sigma$ que indicam transporte para ESE (Figura 7.1.A). Esses porfiroclastos apresentam finas bordas de recristalização em estado sólido, mantendo o seu formado subeuhédrico prismático (cf. Figura 6.4).

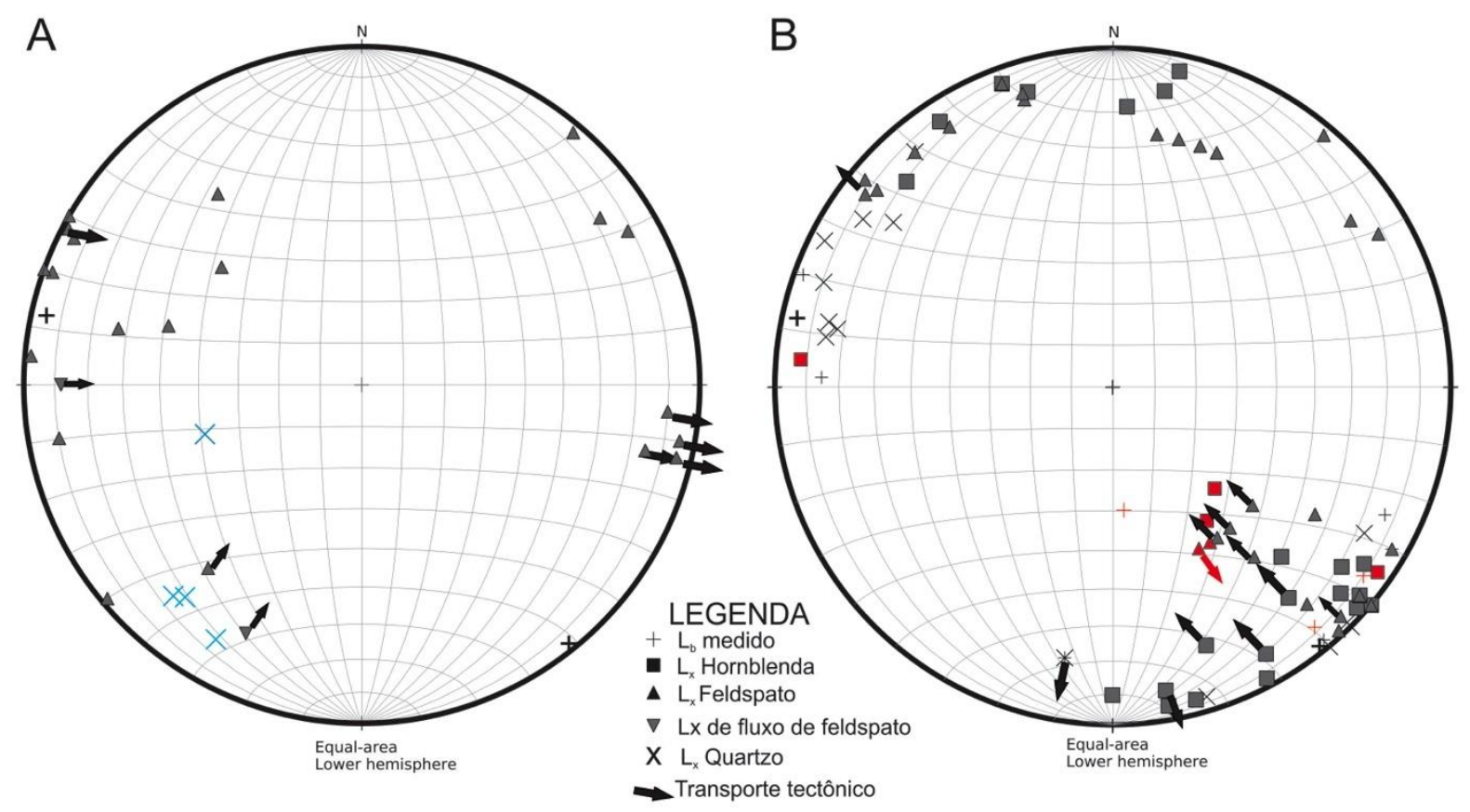

Figura 7.1 - Projeção estereográfica das diferentes lineações minerais. (A) Transporte sin-magmático para NE e transição para transporte em estado sólido para ESE. (B) Transporte tectônico para NW em estado sólido e transporte posterior para S. A cor cinza refere-se aos dados da Unidade Diatexítica, a azul, aos dados da Unidade Metatexítica e a vermelha aos dados da Unidade Granulítica Basal. 
O transporte para ESE é, entretanto, caracterizado pela ação combinada de porfiroclastos manteados em estado sólido e fenocristais subeuhédricos orientados (Figura 7.2.C). Esse comportamento pode refletir um comportamento, já em níveis crustais mais rasos e em condições de baixa viscosidade, onde a recristalização de cristais precoces ocorreu ao mesmo tempo que a cristalização de fenocristais tardios. À NW de São Sebastião da Grama, foram preservadas estruturas sinmagmáticas com transporte para NE e, na altura da cidade de São José do Rio Pardo, o transporte passa a ser para ESE já em estado sólido.

A orientação principal de transporte tectônico em estado sólido é NW-SE e está associado às lineações marcadas por feldspato, hornblenda e quartzo (Figura 7.1.B). Os porfiroclastos manteados do tipo $\sigma$ de feldspato alcalino (Figura 6.2.C) configuram lineações de estiramento com caimentos entre $40-60^{\circ}$ para SE e indicam transporte para $\mathrm{N} 40^{\circ} \mathrm{W}$. Já as lineações marcadas por hornblenda apresentam caimentos de até $40^{\circ}$ para SE, com uma menor densidade de lineações com caimento para $S 10^{\circ} \mathrm{E}$. A hornblenda desenvolve uma lineação de orientação mineral que pode, nos hornblenda granitóides miloníticos da suíte SJRP, desenvolver porfiroclastos do tipo fish ou estirados em pinch-and-swell, indicando um transporte para $\mathrm{N} 40^{\circ} \mathrm{W}$. Foliações do tipo S/C', cuja banda C' é marcada por cristais de biotita (Figura 7.2.E), corroboram com uma movimentação para NW. Esse transporte, na foliação $S_{1}$ principal, é com movimentação inversa e oblíqua.

Segundo Kruse \& Stunitz (1999) e Altenberger \& Wilhelm (2000), a geração de porfiroclastos manteados de feldspato alcalino ocorre sob temperaturas $<600^{\circ} \mathrm{C}$, e a deformação cristaloplástica da hornblenda (para gerar fishes e/ou pinch-andswell) acima dos $700^{\circ} \mathrm{C}$ (Kruse \& Stunitz, 1999). Com isso, sugere-se que o transporte tectônico, em estado sólido, para NW ocorreu sob altas temperaturas, porém mais baixas do que aquelas associadas ao transporte para NE e ESE na presença de líquido anatético. Além disso, o fato de haver pseudomorfos de fusão deformados nas rochas diatexíticas é outro indicativo transporte de mais baixa temperatura posterior ao fluxo sin-magmático.

\subsubsection{Zonas de cisalhamento dúcteis normais}

Entre as cidades de Tapiritiba e Guaxupé, nos granulitos basais, são geradas lineações de estiramento de feldspato alcalino e lineações de orientação de hornblenda com caimento entre $45^{\circ}-50^{\circ}$ para SE. O transporte tectônico indicado 
pelos porfiroclastos de feldspato alcalino é de caráter normal para SE, sugerindo uma zona de cisalhamento dúctil no contato superior dessa unidade.

$\mathrm{Na}$ Unidade Diatexítica, ocorrem zonas de cisalhamento responsáveis por faixas ultramiloníticas (ca. de $7 \mathrm{~cm}$ de espessura, cf. Figura 6.3.B) com direção NESW que mergulham cerca de $45^{\circ}$ para SE. Nessas falhas, occorrem lineações de feldspato alcalino e hornblenda dip-slip que se associam a porfiroclastos assimétricos finos de feldspato que indicam uma componente normal.

O transporte tectônico para $S$ não está somente associado a zonas de cisalhamento dúcteis. Lineações de orientação de hornblenda com baixo caimento para $S 10^{\circ} \mathrm{E}$ e lineações de estiramento de quartzo com baixo caimento para $\mathrm{S} 20^{\circ} \mathrm{W}$ se combinam com estruturas S/C'marcadas por quartzo e feldspato (Figura 7.2.C). 

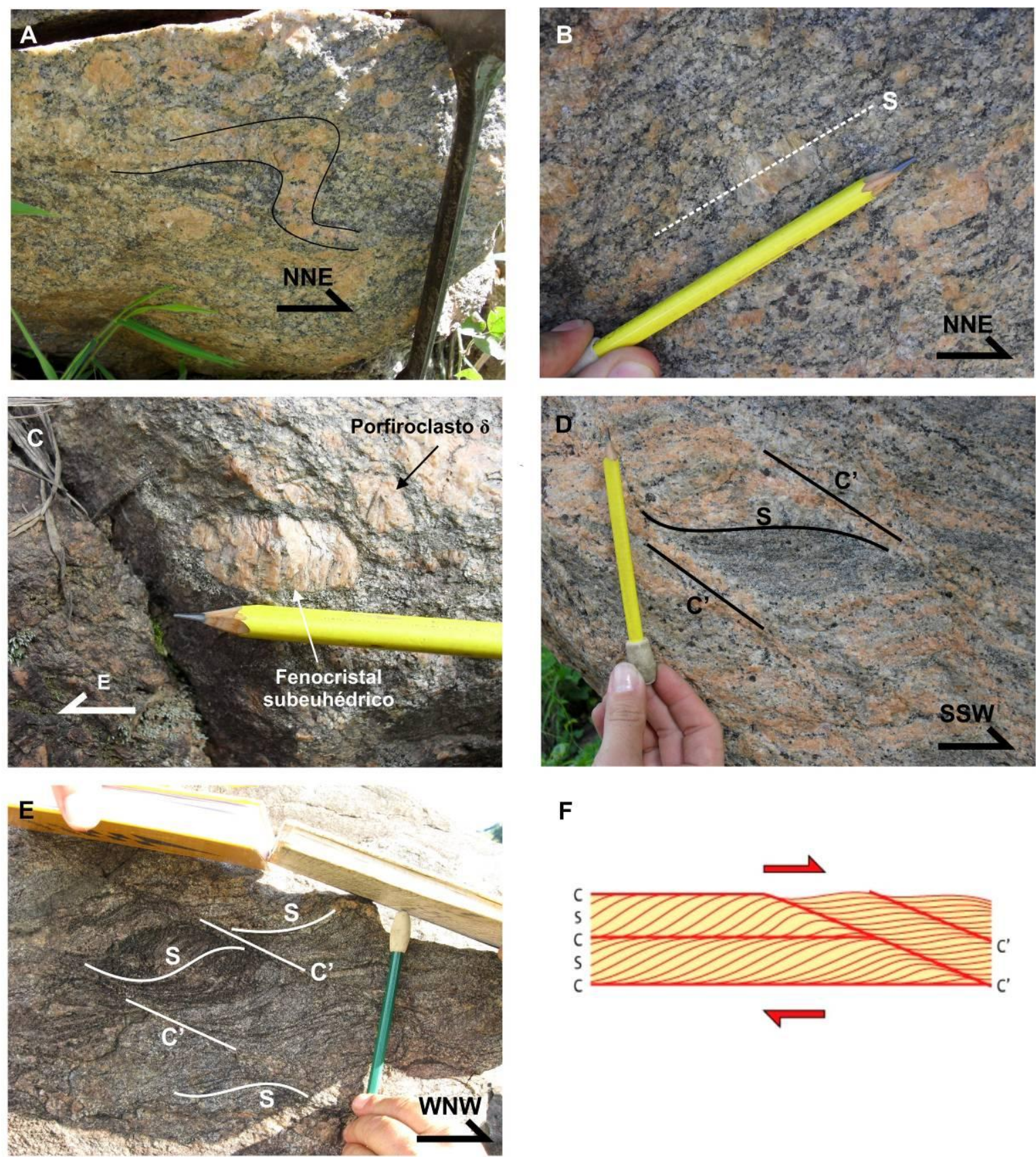

$\mathbf{F}$

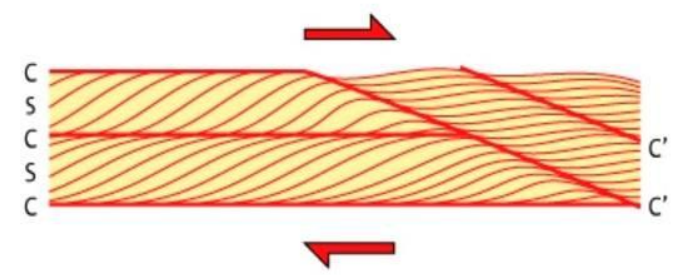

Figura 7.2 - (A) Dobra assimétrica sin-magmática indicando movimentação para NE. Observar falta de foliação plano-axial, intensa desarmonia com o resto da rocha e acúmulo de schliere de biotita em zona de charneira; (B) No centro da figura temos um cristal euhédrico de feldspato alcalino com eixo maior paralelo à foliação $S$ de pares S/C (na Figura 6.2.A observa-se o arranjo S/C); (C) Convivência entre cristal de feldspato alcalino porfiroclástico e subeuhédrico; (D) Banda extensional de cisalhamento com arranjo S/C' indicando transporte tectônico para SSW. Observar alojamento de porções quartzo-feldspáticas nas bandas C' e concentração de biotita nas bandas S; (E) Banda extensional de cisalhamento com alojamento de biotita nas bandas C', concordante com o transporte em estado sólido para NW; (F) Esquema mostrando as bandas de cisalhamento de acordo a movimentação destral (retirado de Trouw et al. 2010). 


\section{CAPÍTULO 8}

\section{GEOQUÍMICA DOS ELEMENTOS MAIORES, TRAÇOS E TERRAS RARAS}

A escolha das amostras para as análises químicas se baseou na tentativa de representar os diferentes tipos litológicos da região pertencente às grandes unidades da área de estudo (Unidade Granulítica basal, Unidade Diatexítica Intermediária e Unidades Metatexítica Superior). Para representar as relações de fusão parcial, foram coletadas amostras correlatas de neossomas e paleossomas. Ao todo foram selecionadas onze amostras para determinação de elementos maiores, elementos traço e elementos terras raras (ETR). Na Tabela 8 estão listadas essas amostras e os resultados das análises estão nas Tabelas 8.1 e 8.2.

\begin{tabular}{|c|c|c|c|c|}
\hline Amostra & Nome textural & $\begin{array}{l}\text { Associação } \\
\text { (Unidade/Suíte) }\end{array}$ & $\begin{array}{l}\text { Elementos } \\
\text { Maiores }\end{array}$ & $\begin{array}{l}\text { Elementos } \\
\text { Menores } \\
\text { (+ETR) }\end{array}$ \\
\hline$G x-22 C$ & $\begin{array}{l}\text { Hbl-Czo-Ep gnaisse } \\
\text { quartzo- } \\
\text { monzodiorítico }\end{array}$ & Diatexítica/Pinhal & Sim & Sim \\
\hline Gx-48 & $\begin{array}{l}\text { Cpx-Hbl gnaisse } \\
\text { charnockítico }\end{array}$ & Diatexítica/S.J.R.P & Sim & Não \\
\hline Gx-49D & $\begin{array}{l}\text { Bt-Hbl-Cpx gnaisse } \\
\text { charnockítico }\end{array}$ & Diatexítica/S.J.R.P & Sim & Não \\
\hline Gx-76C & Bt-Cpx-Hbl gnaisse & Granulítica Basal & Sim & Sim \\
\hline Gx-76E & Hbl-Bt sienogranito & Diatexítica/Pinhal & Sim & Sim \\
\hline Gx-76K & $\begin{array}{l}\text { Bt-Cpx gnaisse } \\
\text { charnockítico }\end{array}$ & Granulítica Basal & Sim & Sim \\
\hline Gx-77A2 & $\begin{array}{l}\text { Bt-Hbl monzo- } \\
\text { granodiorito } \\
\text { (neossoma) }\end{array}$ & $\begin{array}{l}\text { Metatexítica/ } \\
\text { Caconde }\end{array}$ & Sim & Sim \\
\hline Gx-77B1 & $\begin{array}{l}\text { Bt-Hbl gnaisse } \\
\text { (Paleossoma/ } \\
\text { resíduo) }\end{array}$ & $\begin{array}{l}\text { Metatexítica/ } \\
\text { Caconde }\end{array}$ & Sim & Sim \\
\hline Gx-78A & $\begin{array}{l}\text { Hbl-Cpx gnaisse } \\
\text { charno-enderbítico } \\
\text { (Paleossoma) }\end{array}$ & Diatexítica/S.J.R.P & Sim & Sim \\
\hline Gx-78B & $\begin{array}{l}\text { Hbl-Cpx gnaisse } \\
\text { Mangerítico } \\
\text { (Neossoma) }\end{array}$ & Diatexítica/S.J.R.P & Sim & Sim \\
\hline Gx-78C & $\begin{array}{l}\text { Hbl quartzo- } \\
\text { monzonito }\end{array}$ & Diatexítica/S.J.R.P & Sim & Não \\
\hline
\end{tabular}


Além dos dados obtidos neste trabalho, foram compilados dados geoquímicos referentes à unidade dos Granulitos Basais, Suíte São José do Rio Pardo e Suíte Granito-Migmatítica Pinhal dos trabalhos de Janasi (1999) e Campos Neto et al. (1988).

\subsection{Elementos Maiores}

A variação dos elementos maiores $\left(\mathrm{Al}_{2} \mathrm{O}_{3}, \mathrm{CaO}, \mathrm{Na}_{2} \mathrm{O}, \mathrm{K}_{2} \mathrm{O}, \mathrm{Fe}_{3} \mathrm{O}_{3}, \mathrm{MgO}\right.$, $\mathrm{P}_{2} \mathrm{O}_{5}$ e $\mathrm{TiO}_{2}$ ) está representada em diagramas Harker utilizando a sílica como índice de discriminação (Figura 8). No geral, o conjunto de rochas analisadas apresenta uma boa correlação negativa entre $\mathrm{Fe}_{2} \mathrm{O}_{3}, \mathrm{TiO}_{2}, \mathrm{CaO}$ e MgO. Destaca-se uma correlação positiva com $\mathrm{K}_{2} \mathrm{O}$ muito bem marcada. $\mathrm{O}$ conjunto apresenta uma evolução segundo a série cálcio alcalina (Figura 8.1.A), predominando entre a série cálcio alcalina de alto potássio e a shoshonítica (Figura 8.1.B). Os granulitos máficos, menos diferenciados, estão fora das tendências principais, exibindo menores teores de $\mathrm{Na}_{2} \mathrm{O}, \mathrm{TiO}_{2}$ e $\mathrm{P}_{2} \mathrm{O}_{5}$ (Figura 8), além de se encontrarem no limite entre as séries toleítica e cálcio alcalina (Figura 8.1.B). Segundo o diagrama de Shand (1943), observa-se um caráter dominantemente metaluminoso com a exceção de poucos diatexitos peraluminosos subordinados (Figura 8.1.D).

A Unidade Granulítica Basal abrange granulitos básicos, com ca. 45-50 wt\% de sílica, intermediários variando entre 57-65 wt\% e ácidos com teores de sílica maiores do que $70 w t \%$. Desde as composições menos diferenciadas até as mais diferenciadas, somente $\mathrm{CaO}, \mathrm{Fe}_{2} \mathrm{O}_{3}$ e $\mathrm{MgO}$ apresentam correlação negativa com a sílica. $\mathrm{Al}_{2} \mathrm{O}_{3}$ e $\mathrm{Na}_{2} \mathrm{O}$ apresentam correlações positivas nas composições básicas, e negativas nas composições intermediário a ácidas. Para $\mathrm{TiO}_{2}$ e $\mathrm{P}_{2} \mathrm{O}_{5}$, os granulitos máficos não apresentam correlações com a sílica, mantendo-se, respectivamente, em 0.5 e 0.2 wt\%. Já para as composições félsicas, esse dois elementos apresentam correlações negativas. O bt-cpx-hbl gnaisse (Gx-76C), associado à Unidade Granulítica Basal, apresenta uma forte correlação com os granulitos de composição básica, com exceção do conteúdo de $\mathrm{TiO}_{2}$, onde a amostra apresenta quantidade três vezes maior do que as amostras compiladas. Já o gnaisse charnockítico Gx-76K assemelha-se aos granulitos intermediários.

Segundo a Figura 8.1.A e B, os granulitos básicos são toleíticos a cálcioalcalinos, enquanto que os intermediários apresentam-se shoshoníticos e os ácidos cálcio-alcalinos. 

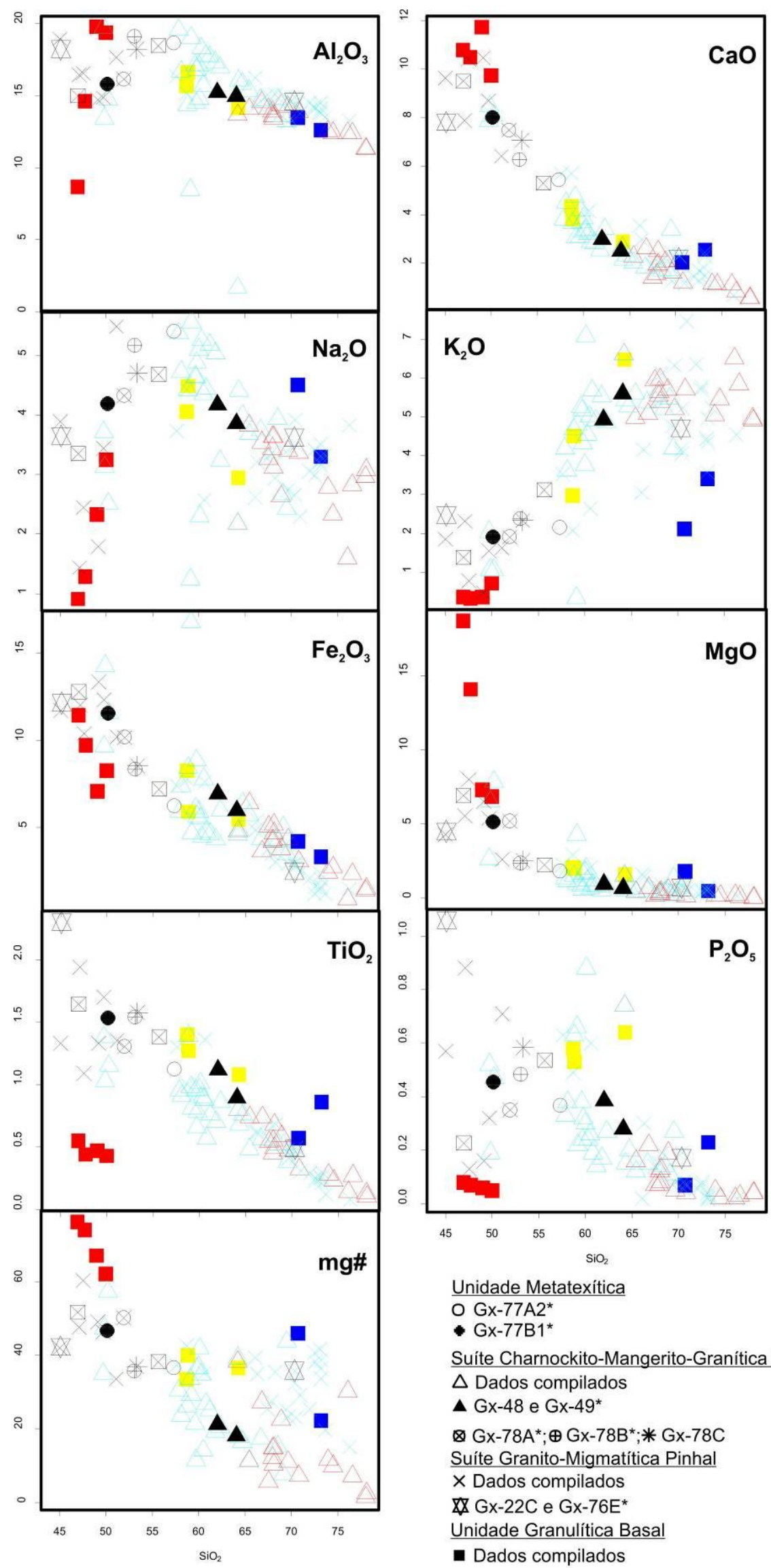

Suite Charnockito-Mangerito-Granítica SJRP

$\triangle$ Dados compilados

- $\mathrm{Gx}-48$ e Gx-49*

$\otimes \mathrm{Gx}-78 \mathrm{~A}^{*} ; \oplus \mathrm{Gx}-78 \mathrm{~B}^{*} ; *$ Gx-78C

Suite Granito-Migmatítica Pinhal

$\times$ Dados compilados

Gx-22C e Gx-76E*

Unidade Granulítica Basal

- Dados compilados

ब $\mathrm{Gx}-76 \mathrm{C} / \mathrm{K}^{*}$

Figura 8 - Diagramas de Harker entre elementos maiores (wt\%) e número de magnésio (mg\#) vs. sílica (wt\%) com dados compilados da literatura e dados desta dissertação $\left(^{*}\right)$. Basal: vermelho são granulitos máficos, amarelos são intermediários e azuis são ácidos; SJRP: triângulo vermelho são hornblenda granitóides, e ciano são charnockitos e mangeritos; Pinhal: X preto são paleossomas e ciano são diatexitos. 
Dentre os litotipos da Unidade Diatexítica, a Suíte São José do Rio Pardo (SJRP) apresenta rochas charnockíticas e mangeríticas com conteúdo de sílica entre 55-70 wt\% e hornblenda granitóides mais diferenciados com variações entre 62-78 wt\%, denotando um caráter bimodal. Segundo a classificação normativa (Figura 8.1.C), essas rochas são quartzo-monzonitos a granitos de afinidade shoshonítica (Figura 8.1B). Os charnockitos Gx-49D e Gx-48 estão no campo das rochas charnockíticas da suíte SJRP enquanto que o paleossoma Gx-78A e os neossomas Gx-78B e Gx-78C restringem-se a teores de sílica entre 50-55 wt\% e apresentam correlações positivas com $\mathrm{Al}_{2} \mathrm{O}_{3}, \mathrm{Na}_{2} \mathrm{O}, \mathrm{K}_{2} \mathrm{O}, \mathrm{TiO}_{2}$ e $\mathrm{P}_{2} \mathrm{O}_{5}$, e negativas com $\mathrm{CaO}, \mathrm{MgO}$ e $\mathrm{Fe}_{2} \mathrm{O}_{3}$.

A Suíte Granito-Migmatítica Pinhal apresenta paleossomas com quantidades de sílica entre 45-52 wt\% e rochas diatexíticas mais diferenciadas entre 55-75 wt\%. Com exceção do potássio, todos os elementos apresentam uma correlação negativa com a sílica, tanto para a suíte SJRP como para a Suíte Pinhal, destacando-se teores mais altos de $\mathrm{Al}_{2} \mathrm{O}_{3}$ entre 15-20 wt $\%$, teores $<10$ wt $\%$ de $\mathrm{CaO}, \mathrm{Fe}_{2} \mathrm{O}_{3}$, e $\mathrm{MgO}$ e teores $<2 w t \%$ de $\mathrm{P}_{2} \mathrm{O}_{5}$ e $\mathrm{TiO}_{2}$. O sódio apresenta uma correlação negativa entre 1.5-5 wt\% para a suíte SJRP e uma grande dispersão entre os membros da suíte Pinhal. Uma forte correlação positiva é observada com o potássio para as duas suítes. As amostras Gx-22C e Gx-76E apresentam-se compatíveis com a evolução da suíte Pinhal, respectivamente, como paleossoma e granito diatexítico, como destacado pelo mg\#. Segundo a classificação normativa (Figura 8.1.C), as rochas da suíte Pinhal são granodioríticas e apresentam afinidades shoshoníticas a cálcioalcalinas de alto potássio (Figura 8.1.B).

As amostras Gx-77B1 e Gx-77A2, respectivamente, paleossoma e neossoma da Unidade Metatexítica, apresentam correlações positivas de $\mathrm{Al}_{2} \mathrm{O}_{3}, \mathrm{Na}_{2} \mathrm{O}$ e $\mathrm{K}_{2} \mathrm{O}$, e negativas de $\mathrm{CaO}, \mathrm{Fe}_{2} \mathrm{O}_{3}, \mathrm{MgO}, \mathrm{TiO}_{2}$ e $\mathrm{P}_{2} \mathrm{O}_{5}$, destacando-se um paleossoma com maior mg\# do que o leucossoma. Tratam-se de rochas granodioríticas com afinidades cálcio-alcalinas de alto potássio (Figura 8.1.B e C).

A Figura 8.2 apresenta um diagrama entre elementos maiores compatíveis e incompatíveis. Observa-se a distinção de dois campos opostos, um que contém rochas diatexíticas (melt-rich) e outro que contém rochas residuais (residuum-rich). De acordo com Sawyer (2010), esses diagramas são bons para separar o paleossoma do neossoma (porções diatexíticas e porções residuais). 
A linha de conexão L1, traçada entre o leucossoma charnockítico Gx-76K e o possível paleossoma $\mathrm{Gx}-76 \mathrm{C}$, aponta para uma composição de $(\mathrm{MgO}+\mathrm{CaO})$ que é observada nos granulitos bandados de composição máfica, podendo sugerir que eles são o resíduo deixado a partir da extração do leucossoma charnockítico. Esse resíduo apresenta afinidade toleítica, enquanto que os granulitos máficos um pouco mais pobres em $(\mathrm{MgO}+\mathrm{CaO})$ já apresentam afinidades cálcio alcalinas, possivelmente refletindo características do paleossoma. Já o leucossoma charnockítico segregado apresenta afinidades cálcio alcalinas de alto potássio a shoshoníticas.
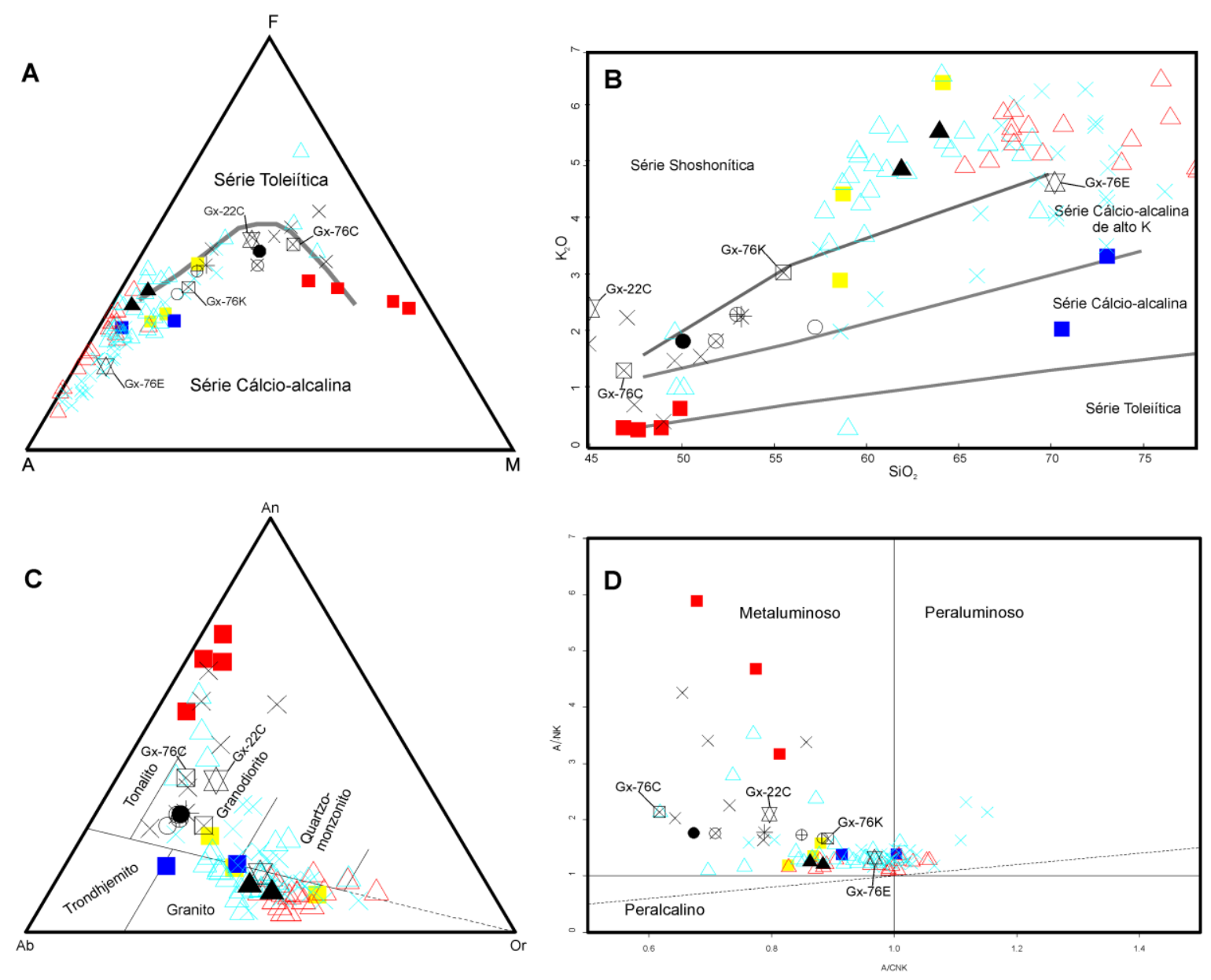

Figura 8.1 - (A) Diagrama AFM com a curva de Irvine \& Baragar (1971) separando as séries toleiítca e cálcioalcalina; (B) Diagrama binário de Paccerillo \& Taylor (1976) com as séries magmáticas baseadas no conteúdo de potássio; (C) Diagrama ternário Ab-An-Or normativo de O'Connor (1965) para classificação de rochas plutônicas; (D) Diagrama A/NK vs. A/CNK de Shand (1943) para o caráter aluminoso e alcalino das rochas graníticas. Legenda segue a mesma que a Figura 8.

Dentre as amostras da suíte SJRP, o neossoma mangerítico Gx-78B e o neossoma quartzo-monzonítico $\mathrm{Gx}-78 \mathrm{C}$ apresentam uma tendência às rochas diatexíticas. A linha de conexão L2, passando pelo possível paleossoma Gx-78A, 
pode ser estendida até variações de $(\mathrm{MgO}+\mathrm{CaO})$ que correspondem a rochas granulíticas de composição máfica, porém com cerca de 5 wt\% a mais de $(\mathrm{MgO}+\mathrm{CaO})$ do que os resíduos da Unidade Granulítica Basal.

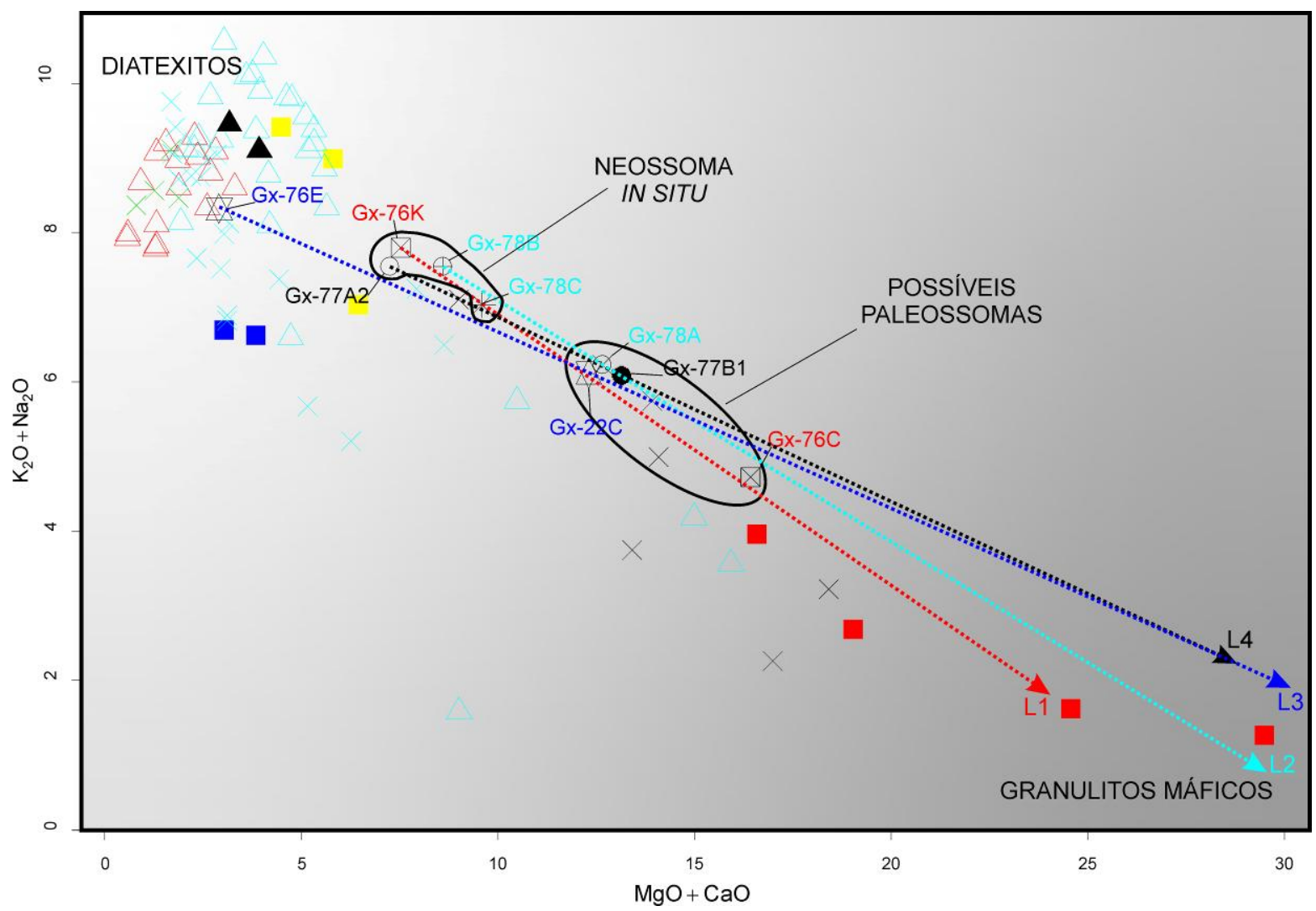

Figura 8.2 - Diagrama binário de elementos incompatíveis vs. elementos compatíveis mostrando os campos das rochas diatexíticas, dos neossomas in situ, dos possíveis paleossomas e das rochas residuais. As linhas pontilhadas são linhas de conexão (L1, L2, L3 e L4) a partir dos leucossomas in situ (exceto para a amostra Gx-76E) passando por seus possíveis paleossomas. A legenda segue a mesma da Figura 8.

O leucossoma de $\mathrm{Hbl-Bt}$ sienogranito (Gx-76E) da suíte Pinhal já representa rochas com maior grau de fusão, de caráter diatexítico. Estão associados a paleossomas ortognáissicos (representados por $X$ na Figura 8.2) e gnaisses quartzomonzodioríticos (Gx-22C), como indica a linha de conexão L3. De forma semelhante, o paleossoma Gx-77B1 da Unidade Metatexítica está associado ao leucossoma Gx77A2 por meio da linha de conexão L4. 


\subsection{Elementos Traços}

Dentre os elementos do tipo LILE (large-inon lithophile elements) (Figura 8.3), os mais abundantes são Ba (até 5000 ppm) e Sr (até 2000 ppm), seguidos de Rb (até 350 ppm) e Cs (até 2.5 ppm). Os altos valores de Ba e Sr estão relacionados principalmente às rochas das suítes SJRP e Pinhal.

Para a suíte SJRP, o Ba apresenta uma correlação negativa, de modo que as rochas mangerito-charnockíticas apresentem concentrações entre 2000 - 5000 ppm e as rochas graníticas variam entre $100-2000$ ppm. O comportamento do Sr, para as rochas da mesma suíte, é semelhante ao $\mathrm{Ba}$, onde temos maiores concentrações (100-2000 ppm) nas rochas mangerito-charnockíticas do que nas graníticas (50-500 ppm). O Rb apresenta uma correlação positiva e é enriquecido nas rochas graníticas mais diferenciadas. $O$ comportamento desses três elementos reforça $\circ$ caráter bimodal dessa suíte.

A suíte Pinhal apresenta um comportamento mais homogêneo entre seus ortognaisses (paleossoma) e diatexitos, onde os teores de Ba estão entre 500 2000 ppm e os teores de Sr entre 250 - 750 ppm para toda a suíte. O Rb apresenta forte correlação positiva, e, como na suíte SJRP, está seguindo a correlação positiva do $\mathrm{K}$, mostrando o grau de diferenciação.

O comportamento dos elementos de maior raio iônico nos granulitos basais é semelhante, de modo que os granulitos intermediários são mais enriquecidos em $\mathrm{Rb}, \mathrm{Ba}, \mathrm{Cs}$ e $\mathrm{Sr}$ do que os granulitos básicos e ácidos. De modo geral, há uma leve tendência de correlação positiva para esses elementos. Já o migmatito da Unidade Metatexítica apresenta correlação positiva para $\mathrm{Rb}$ e Cs e teores iguais de $\mathrm{Ba}$ e $\mathrm{Sr}$ entre paleossoma e leucossoma.

O $\mathrm{Zr}$ é o mais abundante dentre os elementos do tipo HFSE (high-field strenght elements), apresentando concentrações entre 50-1250 ppm para para charnockitos e mangeritos SJRP, diatexitos Pinhal e granulitos intermediários. Os membros mais diferenciados das duas suítes apresentam teores menores do que 500 ppm, assim como os paleossomas Pinhal e granulitos máficos da Unidade Basal. O neossoma Gx-78B é mais enriquecido do que o paleossoma Gx-78 e o neossoma Gx-77A2 mantém o teor de seu paleossoma associado Gx-77B1. O Nb apresenta um grande espalhamento, com teores até $60 \mathrm{ppm}$. $O$ teor de $U$ se mantém até 5 ppm enquanto que Th e $\mathrm{Pb}$ apresentam uma forte correlação positiva com a sílica. O comportamento do Hf é bem distinto, apresentando uma forte 


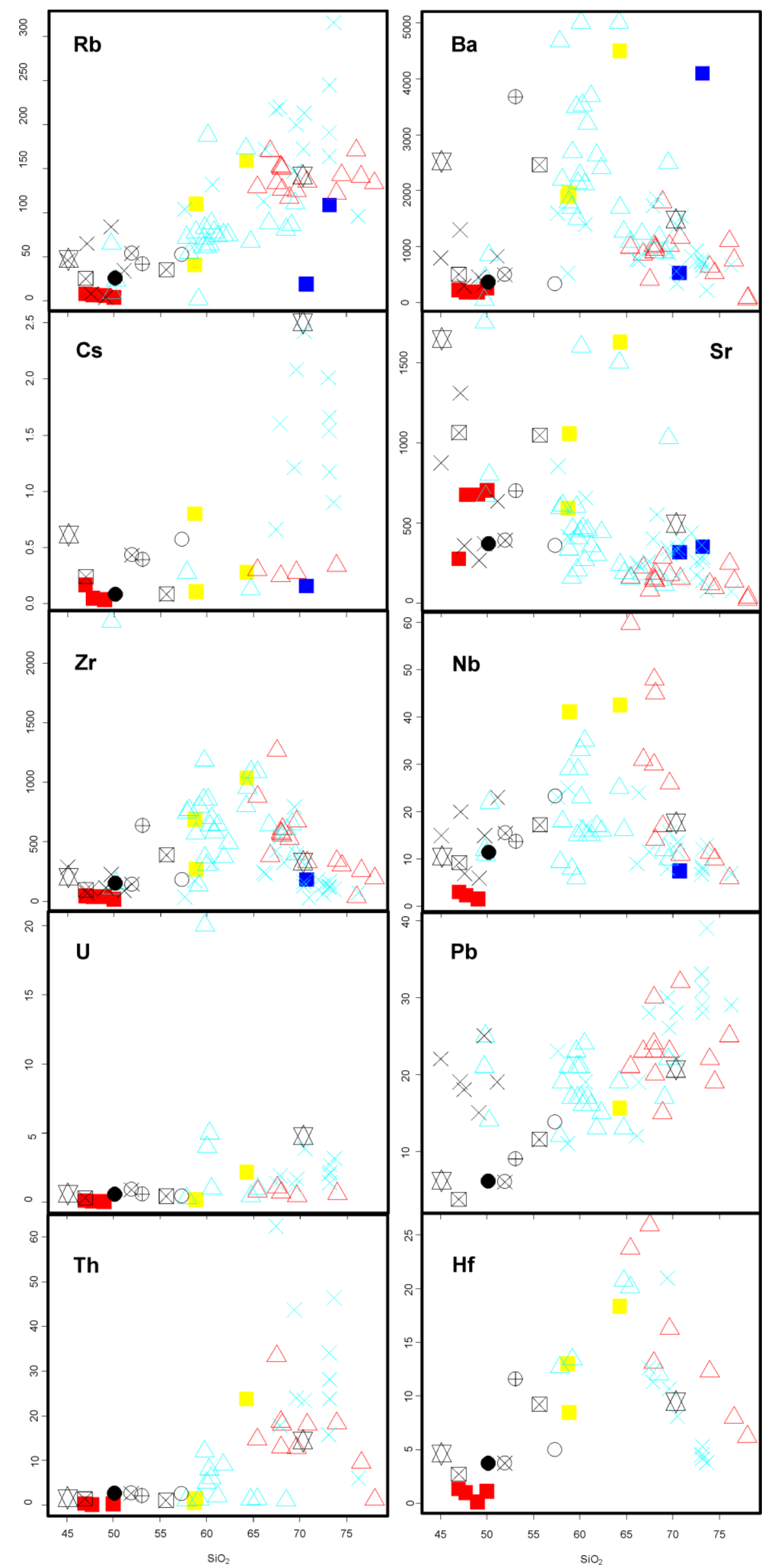

Figura 8.3- Diagramas de Harker entre elementos traço (em ppm) vs. sílica (wt\%). Legenda como na Figura 8. 
correlação negativa (25-5ppm) para as composições maiores do 65 wt\% de sílica, principalmente para a suíte SJRP e Pinhal. Para as composições menos diferenciadas, ocorre certa correlação positiva entre $0-15 p p m$, inclusive para os pares paleossoma-neossoma.

\subsubsection{Elementos Terras Raras (ETR)}

A Figura 8.4 apresenta o padrão dos elementos terras raras normalizados para valores condríticos segundo Bayton (1984).

Os granulitos máficos da Unidade Granulítica Basal apresentam baixo fracionamento de ETR, com razão média $(\mathrm{La} / \mathrm{Yb})_{\mathrm{N}}=6.48$ e leves anomalias $\left(\mathrm{Eu} / \mathrm{Eu}^{*}\right)_{\mathrm{N}}$ variando entre 1.13 e 0.86 . Os valores máximos de $L a_{N}=36$ diferem esses granulitos daqueles félsicos de composições intermediário-ácidas, os quais têm uma razão média de fracionamento dos ETR $(\mathrm{La} / \mathrm{Yb})_{N}=37.66$ e distintos valores de fracionamento entre ETR-leves e pesados, respectivamente, $(\mathrm{La} / \mathrm{Sm})_{\mathrm{N}}=5.36 \mathrm{e}$ $(\mathrm{Eu} / \mathrm{Yb})_{\mathrm{N}}=4.43$. A amostra $\mathrm{Gx}-76 \mathrm{~K}$, apesar de apresentar leve anomalia positiva de Eu, está compatível com o fracionamento dos granulitos intermediários com os maiores fracionamentos de ETR-leves. A amostras Gx-76C, apesar de não ser granulítica, é compatível com o fracionamento dos granulitos ácidos com os menores fracionamentos de ETR-leves e sem anomalia de Eu.

Os diatexitos da Suíte Pinhal são caracterizados por anomalias negativas $\left(\mathrm{Eu} / \mathrm{Eu}^{*}\right)_{\mathrm{N}=0,6}$ e apresentam alto fracionamento de $\mathrm{ETR}$, com razão média $(\mathrm{La} / \mathrm{Yb})_{\mathrm{N}}=95.8$. A amostra $\mathrm{GX}-22 \mathrm{C}$, representando paleossomas da Suíte Pinhal, apresenta $\left(\mathrm{Eu} / \mathrm{Eu}^{*}\right)_{\mathrm{N}}=1.03$ e fracionamento de $(\mathrm{La} / \mathrm{Yb})_{\mathrm{N}}=17.2$.

Os hornblenda-granitoides da Suíte SJRP caracterizam-se por fortes anomalias negativas de Eu com razão média de $\left(\mathrm{Eu} / \mathrm{Eu}^{*}\right)_{\mathrm{N}}=0.46$ ao passo que os charnockitos e mangeritos têm anomalis positivas de Eu com razão média de $\left(\mathrm{Eu} / \mathrm{Eu}^{*}\right)_{\mathrm{N}}=1,78$. O fracionamento de ETR-leves é um bom discriminante entre os hornblenda-granitóides e as rochas charnockito-mangeríticas, sendo que estas últimas têm razão média $(\mathrm{La} / \mathrm{Sm})_{\mathrm{N}}=5.26$ e as primeiras $(\mathrm{La} / \mathrm{Sm})_{\mathrm{N}=3.63}$. $\mathrm{O}$ paleossoma Gx-78A apresenta leve anomalia negativa de Eu e o neossoma Gx-78B forte anomalia positiva de Eu, entretanto, ambas amostras parecem seguir o padrão de ETR das rochas charnockito-mangeríticas.

Quanto aos representantes dos gnaisses migmatíticos da Unidade Metatexítica Superior, o neossoma (Gx-77A2) apresenta fracionamento com razão 
$(\mathrm{La} / \mathrm{Yb})_{\mathrm{N}}=26.37$ e forte anomalia negativa de $\mathrm{Eu}$, enquanto que o paleossoma (GX77B1) apresenta fracionamento com razão $(\mathrm{La} / \mathrm{Yb})_{\mathrm{N}}=13.45$ e anomalia negativa de Eu incipiente.
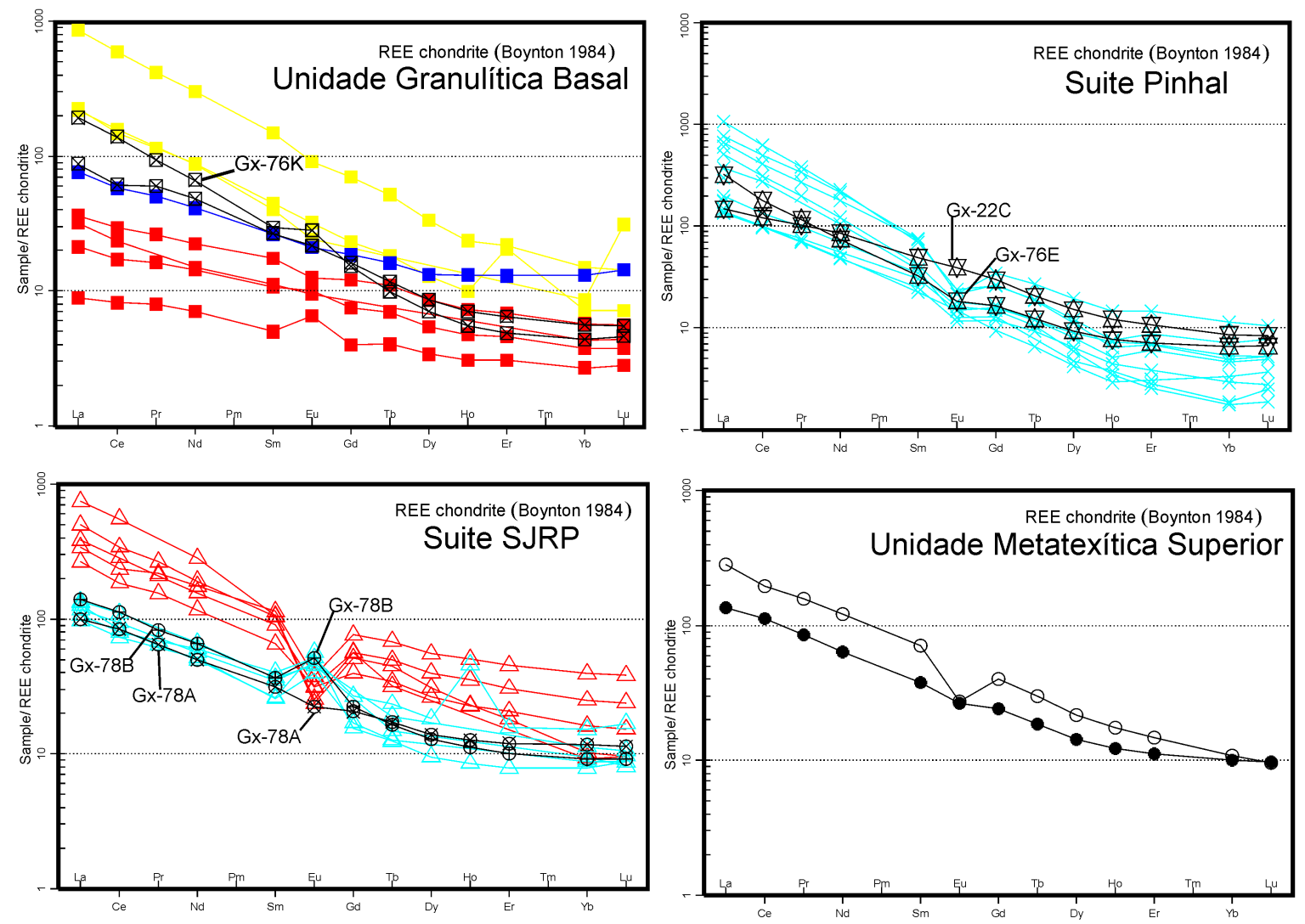

Figura 8.4 - Padrão dos elementos terras raras (ETR) normalizados para valores condríticos (Bayton, 1984) da Unidade Granulítica Basal, da Suíte Pinhal, SJRP e Unidade Metatexítica Superior. Ver discussão no texto. Legenda como na Fig.8. 
Tabela 8.1 - Resultados de análises químicas por FRX e parâmetros geoquímicos. Elementos maiores em \% e elementos menores e traços em ppm.

\begin{tabular}{|c|c|c|c|c|c|c|c|c|c|c|c|}
\hline $\mathrm{SiO}_{2}$ & $\begin{array}{l}\text { GX- } \\
\text { 22C } \\
45.08\end{array}$ & $\begin{array}{l}\text { GX-48 } \\
64.07\end{array}$ & $\begin{array}{l}\text { GX- } \\
\text { 49D } \\
62.01\end{array}$ & $\begin{array}{l}\text { GX- } \\
76 C \\
46.95\end{array}$ & $\begin{array}{l}\text { Gx- } \\
76 \mathrm{E} \\
70.33\end{array}$ & $\begin{array}{l}\text { GX- } \\
76 \mathrm{~K} \\
55.61\end{array}$ & $\begin{array}{l}\text { GX- } \\
\text { 77A2 } \\
57.33\end{array}$ & $\begin{array}{l}\text { GX- } \\
\text { 77B1 } \\
50.14\end{array}$ & $\begin{array}{l}\text { Gx- } \\
\text { 78A } \\
51.93\end{array}$ & $\begin{array}{l}\text { GX- } \\
78 B \\
53.08\end{array}$ & $\begin{array}{l}\text { GX- } \\
78 C \\
53.31\end{array}$ \\
\hline $\mathrm{TiO}_{2}$ & 2.299 & 0.894 & 1.116 & 1.644 & 0.489 & 1.381 & 1.120 & 1.534 & 1.302 & 1.539 & 1.575 \\
\hline $\mathrm{Al}_{2} \mathrm{O}_{3}$ & 18.22 & 14.97 & 15.21 & 14.97 & 14.58 & 18.45 & 18.64 & 15.81 & 16.14 & 19.09 & 18.23 \\
\hline $\mathrm{Fe}_{2} \mathrm{O}_{3}$ & 12.14 & 5.97 & 6.94 & 12.79 & 2.48 & 7.18 & 6.22 & 11.55 & 10.16 & 8.34 & 8.52 \\
\hline $\mathrm{MnO}$ & 0.140 & 0.113 & 0.132 & 0.158 & 0.033 & 0.103 & 0.070 & 0.156 & 0.156 & 0.143 & 0.143 \\
\hline $\mathrm{MgO}$ & 4.50 & 0.67 & 0.94 & 6.93 & 0.70 & 2.24 & 1.81 & 5.13 & 5.18 & 2.33 & 2.52 \\
\hline $\mathrm{CaO}$ & 7.81 & 2.49 & 2.99 & 9.50 & 2.21 & 5.29 & 5.43 & 8.00 & 7.48 & 6.27 & 7.07 \\
\hline $\mathrm{Na}_{2} \mathrm{O}$ & 3.65 & 3.86 & 4.17 & 3.35 & 3.62 & 4.69 & 5.41 & 4.19 & 4.33 & 5.17 & 4.71 \\
\hline $\mathrm{K}_{2} \mathrm{O}$ & 2.47 & 5.60 & 4.93 & 1.38 & 4.70 & 3.11 & 2.14 & 1.90 & 1.90 & 2.37 & 2.33 \\
\hline $\mathrm{P}_{2} \mathrm{O}_{5}$ & 1.057 & 0.279 & 0.385 & 0.226 & 0.172 & 0.536 & 0.367 & 0.454 & 0.350 & 0.483 & 0.583 \\
\hline Loi & 1.68 & 0.32 & 0.24 & 1.42 & 0.42 & 0.78 & 0.74 & 0.56 & 0.48 & 0.30 & 0.44 \\
\hline Total & 99.05 & 99.24 & 99.06 & 99.32 & 99.73 & 99.37 & 99.28 & 99.42 & 99.41 & 99.12 & 99.43 \\
\hline A/NK & 2.09 & 1.2 & 1.24 & 2.13 & 1.32 & 1.67 & 1.66 & 1.76 & 1.75 & 1.72 & 1.77 \\
\hline ASI & 0.843 & 0.901 & 0.885 & 0.623 & 0.981 & 0.919 & 0.902 & 0.688 & 0.721 & 0.872 & 0.812 \\
\hline mg\# & 43.34 & 18.18 & 21.15 & 51.77 & 35.86 & 38.19 & 36.567 & 46.8 & 50.24 & 35.62 & 36.94 \\
\hline $\mathrm{Ba}$ & 2349 & 1664 & 1687 & 561 & 1221 & 2123 & 361 & 392 & 555 & 3115 & 1123 \\
\hline $\mathrm{Ce}$ & 134 & 71 & 106 & 83 & 146 & 153 & 144 & 116 & 81 & 101 & 128 \\
\hline Co & 25 & 3 & 6 & 42 & 5 & 12 & 13 & 30 & 36 & 14 & 21 \\
\hline $\mathrm{Cr}$ & 17 & $<13$ & $<13$ & 197 & $<13$ & $<13$ & $<13$ & 74 & 98 & $<13$ & 13 \\
\hline $\mathrm{Cu}$ & 34 & 5 & 7 & 69 & $<5$ & 33 & 36 & 29 & 37 & 15 & 13 \\
\hline $\mathrm{Ga}$ & 22 & 20 & 20 & 18 & 18 & 23 & 28 & 18 & 18 & 22 & 22 \\
\hline La & 47 & 45 & 66 & $<28$ & 71 & 63 & 88 & 39 & 47 & 48 & 79 \\
\hline $\mathrm{Nb}$ & 9 & 29 & 37 & 9 & 19 & 15 & 22 & 11 & 15 & 14 & 24 \\
\hline Nd & 55 & 38 & 46 & 52 & 15 & 28 & 66 & 47 & 38 & 45 & 69 \\
\hline $\mathrm{Ni}$ & 13 & $<5$ & $<5$ & 103 & 6 & 8 & 9 & 40 & 53 & $<5$ & 14 \\
\hline $\mathrm{Pb}$ & 18 & 15 & 19 & 16 & 17 & 16 & 11 & 10 & 11 & 14 & 16 \\
\hline $\mathbf{R b}$ & 58 & 106 & 71 & 32 & 153 & 44 & 64 & 32 & 67 & 54 & 44 \\
\hline Sc & 22 & $<14$ & $<14$ & 27 & $<14$ & $<14$ & 18 & 27 & 25 & 20 & 20 \\
\hline $\mathrm{Sr}$ & 1836 & 278 & 295 & 1151 & 500 & 1085 & 370 & 383 & 414 & 719 & 515 \\
\hline Th & 9 & $<7$ & $<7$ & $<7$ & 12 & $<7$ & $<7$ & 6 & $<7$ & $<7$ & $<7$ \\
\hline $\mathbf{U}$ & $<3$ & 4 & $<3$ & $<3$ & 4 & $<3$ & $<3$ & 4 & 3 & $<3$ & $<3$ \\
\hline v & 205 & 19 & 8 & 251 & 34 & 99 & 88 & 210 & 190 & 86 & 138 \\
\hline $\mathbf{Y}$ & 27 & 27 & 39 & 17 & 23 & 14 & 36 & 28 & 30 & 27 & 33 \\
\hline Zn & 130 & 80 & 101 & 104 & 31 & 91 & 66 & 117 & 95 & 102 & 96 \\
\hline $\mathrm{Zr}$ & 170 & 747 & 794 & 105 & 309 & 376 & 203 & 160 & 141 & 640 & 276 \\
\hline Cl & $<50$ & $<50$ & 92 & 147 & 140 & 56 & 496 & 788 & 258 & 211 & 552 \\
\hline $\mathbf{F}$ & 866 & $<500$ & $<500$ & 2198 & 556 & $<500$ & 914 & 2613 & 2111 & 1002 & 1391 \\
\hline $\mathbf{s}$ & 986 & $<550$ & $<550$ & 1857 & $<550$ & 1387 & 868 & 1094 & 943 & $<550$ & $<550$ \\
\hline
\end{tabular}


Tabela 8.2 - Resultados de análises químicas por ICP-MS para elementos traços e terras raras (ppm).

\begin{tabular}{|c|c|c|c|c|c|c|c|c|}
\hline & $\begin{array}{l}\text { GX- } \\
\text { 22C }\end{array}$ & GX-76C & GX-76E & GX-76K & $\begin{array}{c}\text { GX- } \\
\text { 77A2 }\end{array}$ & GX-77B1 & GX-78A & GX-78B \\
\hline $\mathbf{R b}$ & 47.2 & 24.9 & 142 & 35.3 & 52.3 & 25.6 & 53.8 & 41.9 \\
\hline Sr & 1649 & 1062 & 496 & 1047 & 359 & 369 & 391 & 701 \\
\hline $\mathbf{Y}$ & 24.3 & 14.6 & 15.6 & 11.2 & 33.6 & 25.0 & 26.5 & 22.3 \\
\hline $\mathrm{Zr}$ & 206 & 95.4 & 332 & 386 & 181 & 149 & 141 & 634 \\
\hline $\mathrm{Nb}$ & 10.6 & 9.27 & 17.7 & 17.3 & 23.3 & 11.5 & 15.5 & 13.7 \\
\hline Cs & 0.62 & 0.24 & 2.50 & 0.09 & 0.57 & 0.08 & 0.43 & 0.39 \\
\hline $\mathrm{Ba}$ & 2524 & 510 & 1483 & 2463 & 336 & 369 & 498 & 3671 \\
\hline La & 46.0 & 27.0 & 99.8 & 59.5 & 88.4 & 41.9 & 31.0 & 43.5 \\
\hline $\mathrm{Ce}$ & 98.1 & 49.5 & 145 & 112 & 159 & 91.0 & 68.4 & 90.6 \\
\hline Pr & 12.5 & 7.31 & 14.3 & 11.5 & 19.1 & 10.3 & 7.88 & 10.1 \\
\hline Nd & 51.6 & 28.8 & 44.7 & 39.6 & 73.2 & 38.5 & 30.0 & 39.6 \\
\hline Sm & 9.60 & 5.19 & 6.38 & 5.74 & 13.9 & 7.37 & 6.10 & 7.12 \\
\hline Eu & 2.89 & 1.59 & 1.36 & 2.07 & 2.00 & 1.93 & 1.65 & 3.76 \\
\hline Gd & 7.71 & 4.20 & 4.31 & 3.95 & 10.3 & 6.26 & 5.33 & 5.75 \\
\hline $\mathrm{Tb}$ & 0.98 & 0.55 & 0.58 & 0.47 & 1.41 & 0.87 & 0.82 & 0.78 \\
\hline Dy & 4.91 & 2.78 & 3.02 & 2.27 & 7.02 & 4.57 & 4.47 & 4.12 \\
\hline Ho & 0.88 & 0.50 & 0.55 & 0.39 & 1.25 & 0.88 & 0.91 & 0.80 \\
\hline Er & 2.25 & 1.34 & 1.49 & 1.02 & 3.07 & 2.34 & 2.51 & 2.11 \\
\hline Tm & 0.30 & 0.19 & 0.21 & 0.14 & 0.39 & 0.33 & 0.36 & 0.29 \\
\hline $\mathrm{Yb}$ & 1.81 & 1.17 & 1.38 & 0.91 & 2.26 & 2.10 & 2.45 & 1.90 \\
\hline Lu & 0.27 & 0.18 & 0.21 & 0.15 & 0.31 & 0.32 & 0.36 & 0.30 \\
\hline Hf & 4.61 & 2.69 & 9.45 & 9.21 & 4.99 & 3.74 & 3.71 & 11.6 \\
\hline $\mathrm{Pb}$ & 6.20 & 3.74 & 20.7 & 11.5 & 13.8 & 6.12 & 6.01 & 9.00 \\
\hline Th & 1.62 & 1.43 & 14.4 & 1.09 & 2.59 & 2.64 & 2.64 & 2.07 \\
\hline $\mathbf{U}$ & 0.62 & 0.33 & 4.79 & 0.46 & 0.46 & 0.58 & 0.91 & 0.62 \\
\hline$(\mathrm{La} / \mathrm{Yb}) \mathrm{N}$ & 17.18 & 15.56 & 48.66 & 43.93 & 26.37 & 13.45 & 8.55 & 15.44 \\
\hline$(\mathrm{La} / \mathrm{Sm}) \mathrm{N}$ & 3.02 & 3.27 & 9.84 & 6.52 & 4.00 & 3.58 & 3.20 & 3.85 \\
\hline$(\mathrm{Eu} / \mathrm{Yb}) \mathbf{N}$ & 4.55 & 3.87 & 2.80 & 6.44 & 2.51 & 2.61 & 1.92 & 5.63 \\
\hline$\left(E u / E u^{\star}\right) N$ & 1.03 & 1.04 & 0.79 & 1.33 & 0.51 & 0.87 & 0.88 & 1.80 \\
\hline
\end{tabular}




\section{CAPÍTULO 9}

\section{GEOCRONOLOGIA E GEOQUÍMICA ISOTÓPICA}

As amostras da Tabela 8, com exceção das amostras Gx-48, Gx-49D e Gx76C, foram analisadas segundo os métodos isotópicos Rb-Sr e Sm-Nd (Tabela 9). Adicionalmente, para as amostras Gx-77A2 e Gx-77B1 foram separados zircões para datação U-Pb (LA-ICP-MS) e análises pontuais de Lu-Hf (LA-ICP-MS). Assim como no capítulo anterior, os dados inéditos deste trabalho estão representados de forma comparativa com dados isotópicos e geocronológicos da literatura (Basei et al. dados inéditos; Janasi 1999; Basei et al. 1995).

\subsection{Unidade Granulítica Basal}

Idades U-Pb em zircão obtidas por SHRIMP (Basei et al. inédito) em rochas granulíticas intermediárias da Unidade Granulítica Basal indicam uma idade concórdia de $638 \pm 2.4$ Ma e uma idade de intercepto de 647 +6.5/-3.8 Ma (Figura 9), interpretadas como sendo a idade dos ortognaisses provenientes do magmatismo sin-orogênico e que, em parte, foram transformados em granulitos e migmatitos (Janasi 2002).

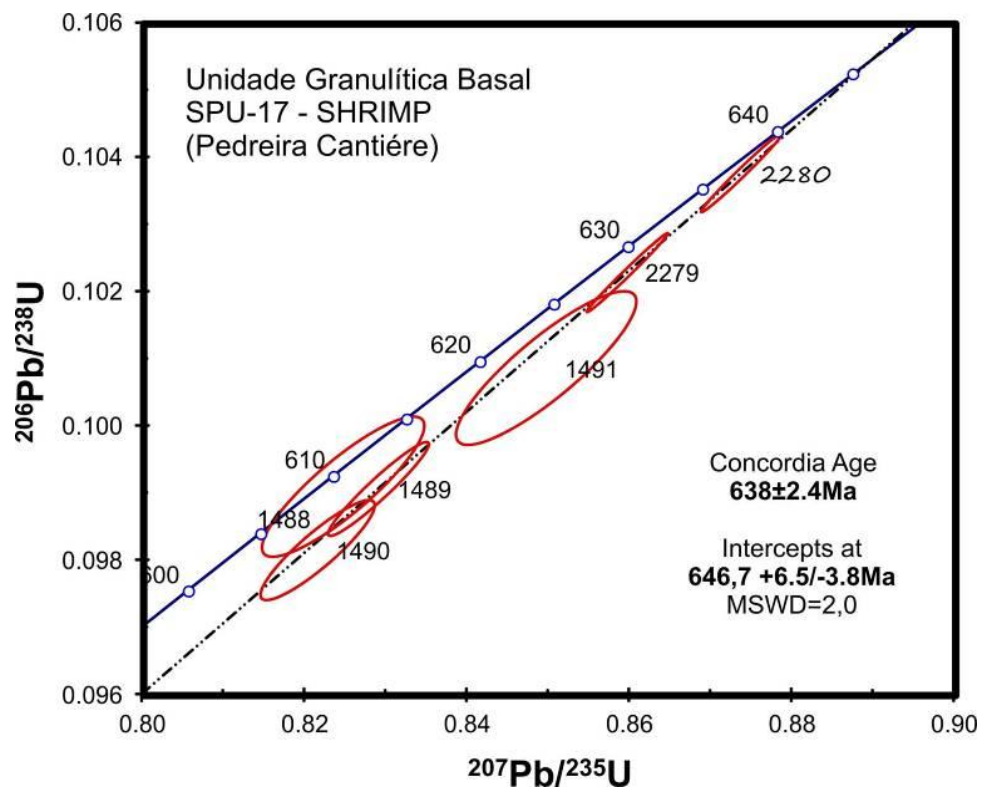

Figura 9 - Diagrama concórdia com idades U-Pb (SHRIMP) para granulitos intermediários da Unidade Granulítica Basal obtidos por Basei et al. (dados inéditos). 
Os granulitos de composição básica apresentam idades modelo ( $\left.T_{D M}\right)$ entre 1.8 e $2.3 \mathrm{Ga}$ e valores de $\varepsilon_{\mathrm{Nd}(640)}$ entre -4 e -9 (Figura 9.1.A). A razão inicial ${ }^{87} \mathrm{Sr}^{86} \mathrm{Sr}_{(640)}$ para essas rochas variam entre 0.705 até 0.708 (Figura 9.1B), indicando que a fonte a partir da qual esses granulitos foram extraídos é relativamente empobrecida em elementos incompatíveis, sugestivamente, a crosta inferior.

As composições intermediárias apresentam três comportamentos distintos. O primeiro é semelhante às rochas de composição básica, com valores de épsilon entre -2 e -10 e razão de estrôncio inicial entre 0.705 e 0.709 , sugerindo também uma fonte a partir da crosta continental inferior (Figura 9.1.B). Essas composições intermediárias mais primitivas são um pouco mais jovens do que as composições básicas, com um período de residência crustal entre 1.3 e $2.0 \mathrm{Ga}$ (Figura 9.1.A).
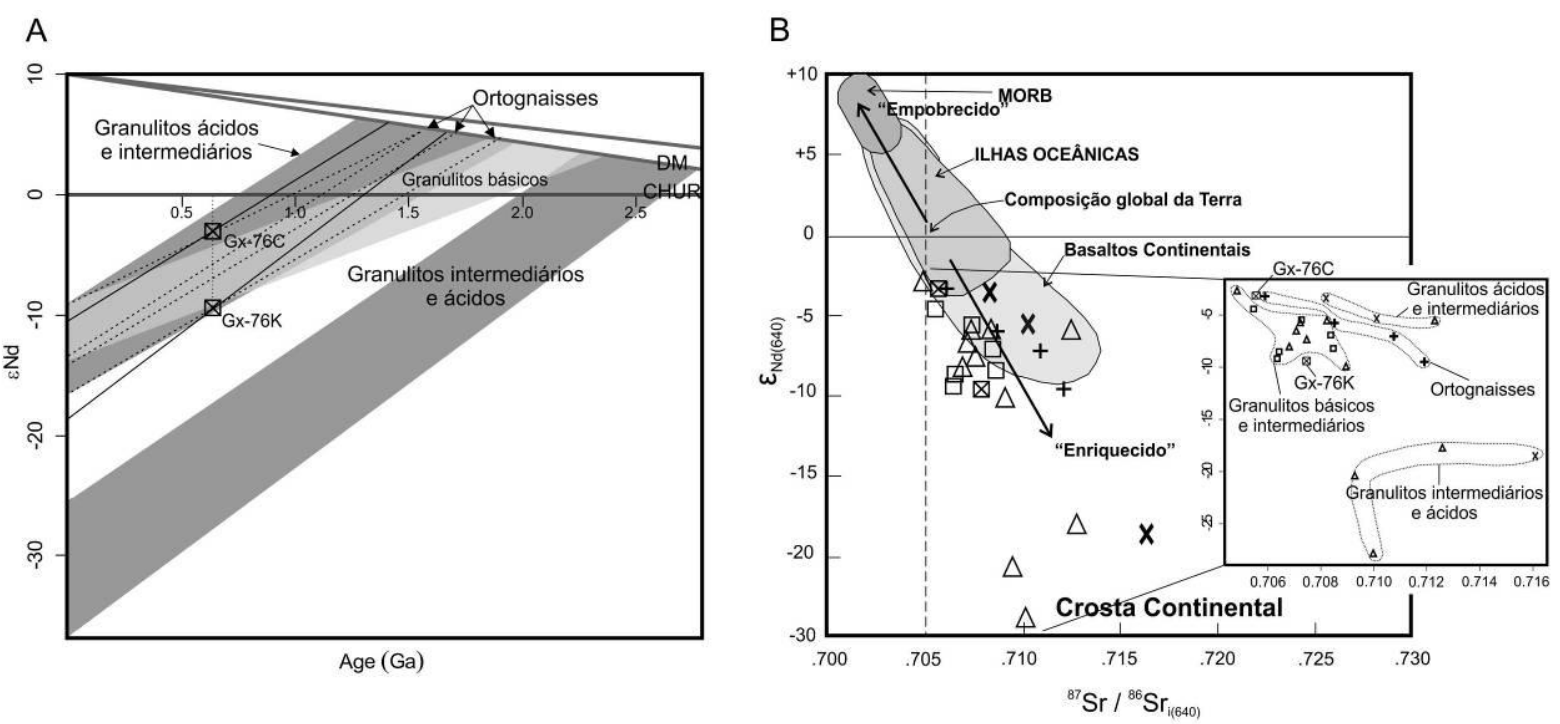

Figura 9.1 - (A) Valores de $\varepsilon_{\text {Nd }}$ com idades modelo a partir das curvas de manto empobrecido (DM) e de reservatório condrítico não empobrecido (CHUR) para as rochas da Unidade Granulítica Basal; (B) Diagrama com $\varepsilon_{\mathrm{Nd}(640)}$ vs. ${ }^{87} \mathrm{Sr}^{86} \mathrm{Sr}_{(640)}$ para as rochas da Unidade Granulítica Basal recalculados para a idade de $640 \mathrm{Ma}$ (cf. Figura 9). Os principais reservatórios apresentados (e.g. MORB, Ilhas oceânicas, Basaltos continentais, Crosta continental) são compilações de White et al. (2005). Em detalhe, estão discriminados quatro grupos para as rochas da Unidade Granulítica Basal (ver texto para explicação). Com exceção das amostras Gx-76C/K (deste trabalho), os dados nos campos em cinza foram compilados de Janasi (1999). As setas rotuladas "empobrecido" e "enriquecido", indicam, respectivamente, áreas-fonte enriquecidas em elementos compatíveis e incompatíveis. Legenda: $(\Delta)$ granulitos intermediários, $(\square)$ granulitos básicos, $(x)$ granulitos ácidos e $(+)$ ortognaisses.

Outro comportamento indicado por um granulito de composição intermediária possui $\varepsilon_{N d(640)}$ de -5.65 e razão inicial de estrôncio de 0.713 , indicando uma fonte já mais enriquecida em elementos incompatíveis. A essa rocha, associam-se granulitos ácidos um pouco mais primitivos (Figura 9.1.B). O último grupo de rochas intermediárias apresenta valores de épsilon entre -17 e -28 com idades modelo mais antigas, entre 2.4 e $2.9 \mathrm{Ga}$. Essas rochas associam-se a uma amostra de composição ácida de idade modelo de $2.2 \mathrm{Ga}, \varepsilon_{\mathrm{Na}(640)}$ de -18 e razão inicial de 
estrôncio de 0.716, mostrando maior residência crustal e uma fonte enriquecida em elementos incompatíveis, sugestivamente, já retrabalhada.

Os ortognaisses, com curvas de evolução pontilhados na Figura 9.1.A, apresentam valores de épsilon pouco negativos, entre -3 e -10 e ${ }^{87} \mathrm{Sr} /{ }^{86} \mathrm{Sr}_{(640)}$ entre 0.705 e 0.712. As idades modelo entre 1.6 e $1.9 \mathrm{Ga}$ indicam menor residência crustal do que os granulitos básicos e intermediários. A amostra Gx-76C (biotitaclinopiroxênio-hornblenda gnaisse) representa o ortognaisse com menor residência crustal e assinaturas isotópicas de uma fonte bem enriquecida em elementos compatíveis, possivelmente mantélitca. Já a amostra Gx-76K (biotita-clinopiroxênio gnaisse charnockítico intermediário) é concordante com os granulitos básicos a intermediários (Figura 9.1.A e B).

\subsection{Unidade Diatexítica}

As rochas da Suíte São José do Rio Pardo (SJRP) apresentam idades U-Pb em zircão obtidas por TIMS (Basei et al. 1995) de $625 \pm 7$ Ma e idades U-Pb obtidas por SHRIMP (Basei et al. inédito) com intercepto em $628 \pm 3.2$ Ma (Figura 9.2). A idade em torno de 625 Ma é admitida como a idade dos charnockitos sin-orogênicos formados a partir da fusão das rochas granulíticas basais (Janasi, 2002). Além disso, essa idade é ainda admitida como pico metamórfico para a NSG (e.g. Basei et al. 1995; Janasi 1999; Martins 2009).

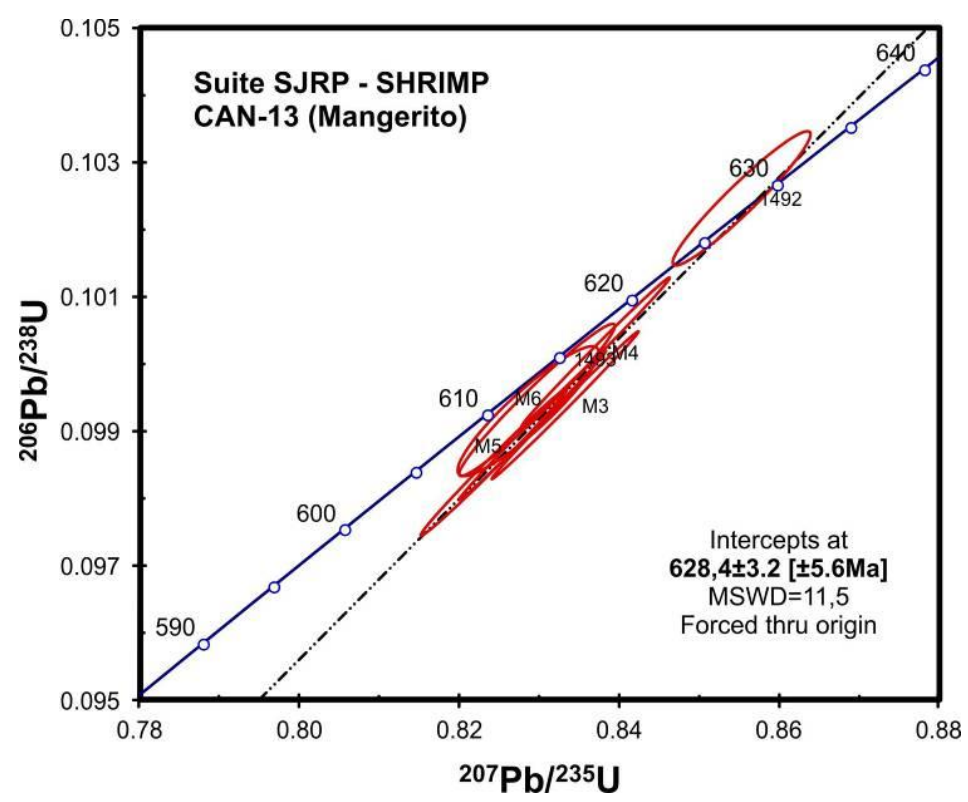

Figura 9.2 - Diagrama concórdia com idade U-Pb (SHRIMP) para a Suíte São José do Rio Pardo obtida por Basei et al. (dados inéditos). 
Dois grupos isotopicamente distintos formam a Suíte SJRP (Janasi, 1999). primeiro, representado pelos maciços São Roque-Itobi e Euclides da Cunha, apresenta $\varepsilon_{\mathrm{Nd}(628)}$ entre -5 e -9 e idades modelo entre 1.4 e $1.65 \mathrm{Ga}$ (Figura 9.3.A). Sua razão inicial ${ }^{87} \mathrm{Sr}^{86}{ }^{8} \mathrm{Sr}_{(628)}$ de 0.707 e os valores pouco negativos de épsilon indicam uma fonte crustal enriquecida em elementos compatíveis, como os níveis crustais mais profundos. O segundo grupo, contendo os maciços Mococa, SJRP e Divinolândia, tem maior residência crustal, com idades modelo mais antigas, entre 1.8 e $2.8 \mathrm{Ga}$, e assinatura isotópica sugerindo fontes fortemente crustais enriquecidas em elementos incompatíveis, como mostrado pelo $\varepsilon_{\mathrm{Nd}(628)}$ entre -10 e $15 \mathrm{e}^{87} \mathrm{Sr} /{ }^{86} \mathrm{Sr}_{(640)}$ entre 0.710 e 0.711 (Figura 9.3.B).
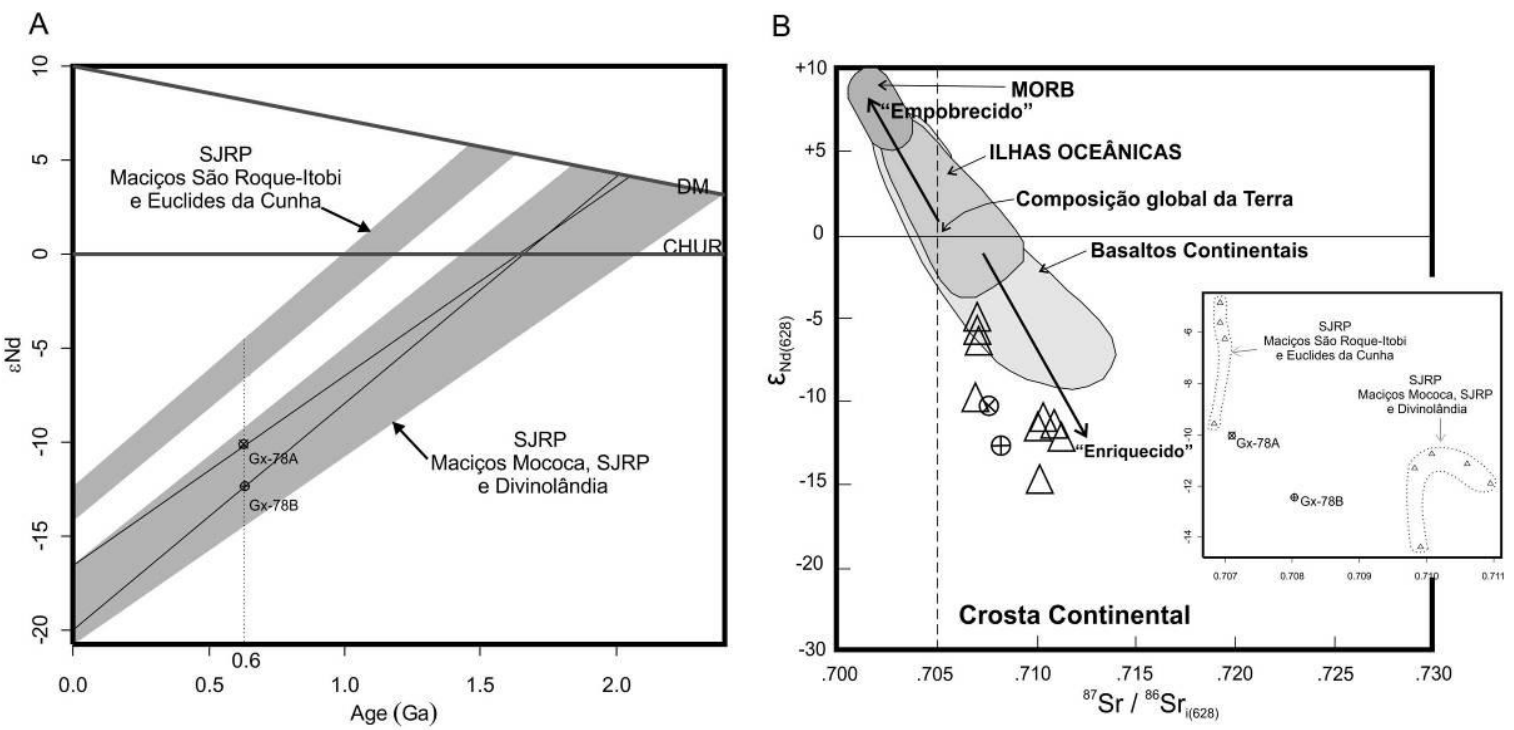

Figura 9.3 - (A) Valores de $\varepsilon_{N d}$ com idades modelo a partir das curvas de manto empobrecido (DM) e de reservatório condrítico não empobrecido (CHUR) para as rochas da Suíte SJRP; (B) Diagrama com $\varepsilon_{\mathrm{Nd}(628)}$ vs. ${ }^{87} \mathrm{Sr}^{86} \mathrm{Sr}_{(628)}$ para as rochas da Suíte SJRP recalculados para a idade de $628 \mathrm{Ma}$ (cf. Figura 9.2). Os principais reservatórios apresentados (e.g. MORB, Ilhas oceânicas, Basaltos continentais, Crosta continental) são compilações de White et al. (2005). Em detalhe estão discriminados os dois principais grupos de rochas da SJRP. As setas rotuladas "empobrecido" e "enriquecido", indicam, respectivamente, áreas-fonte enriquecidas em elementos compatíveis e incompatíveis. As amostras deste trabalho, Gx-78A e Gx-78B, são, respectivamente, paleossoma e leucossoma. Nos campos cinza, dados compilados de Janasi (1999).

O paleossoma Gx-78A (Figura 6.5.A), com idade modelo de $2.03 \mathrm{Ga}$ (Figura 9.3.A), apresenta assinaturas isotópicas próximas ao grupo de rochas oriundas de reservatórios mais ricos em elementos incompatíveis (Figura 9.3.B). Já o leucossoma (Gx-78B) têm uma assinatura intermediária entre e as rochas mais ricas em elementos compatíveis e as mais ricas em elementos incompatíveis, podendo sugerir o início da fusão das rochas da Suíte SJRP.

As rochas da Suíte Granito-Migmatítica Pinhal, predominantemente diatexíticas, apresentam idades U-Pb(zircão) de 625 Ma (Janasi \& Ulbrich 1991; Haddad 1995) em biotita granitos heterogêneos. As idades $T_{D M}$ dessas rochas 
variam entre 1.4 e $1.8 \mathrm{Ga}$, e a variação de $\varepsilon_{\mathrm{Nd}(625)}$ e de ${ }^{87} \mathrm{Sr} /{ }^{86} \mathrm{Sr}_{(625)}$ mostram um predomínio crustal enriquecido como área fonte (Figura 9.4).

A amostra Gx-22C, de composição quartzo-monzodiorítica, tem as mesmas características que os granitos do tipo Pinhal mais empobrecidos, com $\varepsilon_{\mathrm{Nd}(625)}$ de 8.7 e razão ${ }^{87} \mathrm{Sr}^{86} \mathrm{Sr}_{(625)}$ de 0.707 , sendo também o componente com maior residência crustal, já que apresenta idade $\mathrm{T}_{\mathrm{DM}}$ de $1.8 \mathrm{Ga}$. O hornblenda-biotita sienogranito, Gx-76E, apresenta valores de épsilon um pouco mais negativos do que a amostra Gx-22C, também no campo das rochas com razão ${ }^{87} \mathrm{Sr}^{86} \mathrm{Sr}_{(625)}$ entre 0.707 .

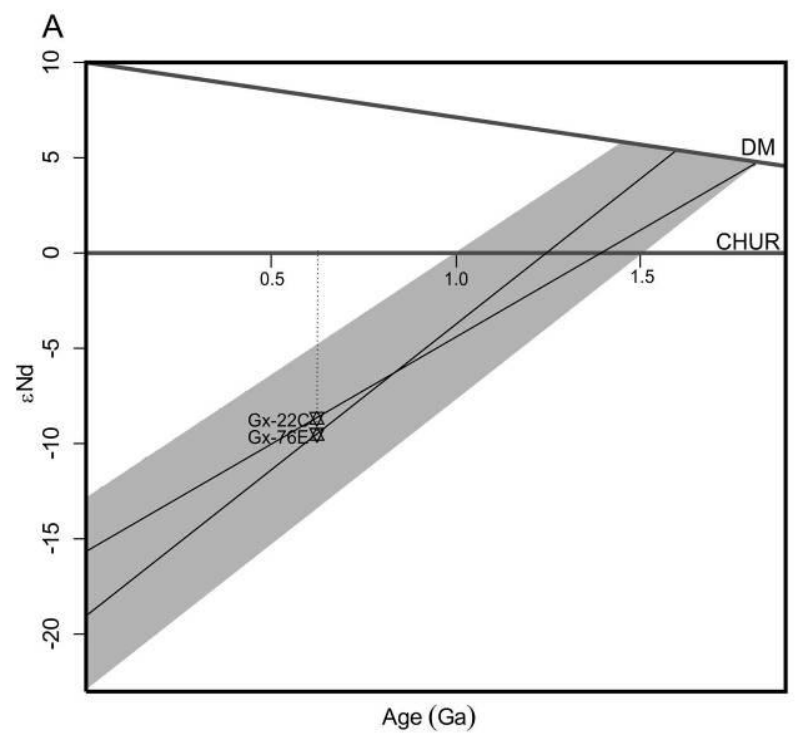

B

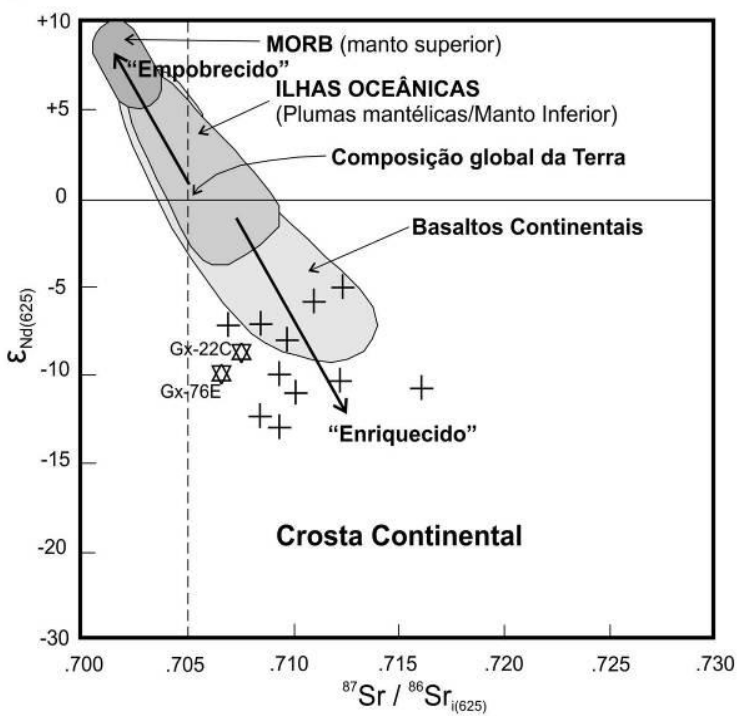

Figura 9.4 - (A) Valores de $\varepsilon_{\text {Nd }}$ com idades modelo a partir das curvas de manto empobrecido (DM) e de reservatório condrítico não empobrecido (CHUR) para as rochas do tipo PInhal; (B) Diagrama com $\varepsilon_{\mathrm{Nd}(625)}$ vs. ${ }^{87} \mathrm{Sr}^{86} \mathrm{Sr}_{(625)}$ para as rochas do tipo Pinhal recalculados para a idade de $625 \mathrm{Ma}$ (cf. Figura 9.2). As setas rotuladas "empobrecido" e "enriquecido", indicam, respectivamente, áreas-fonte enriquecidas em elementos compatíveis e incompatíveis. As amostras Gx-22C e Gx-76E apresentam fontes em crosta continental, sugestivamente, inferior. Os dados nos campos cinza são compilados de Janasi (1999).

\subsection{Unidade Metatexítica}

Os dados isotópicos e geocronológicos da Unidade Metatexítica referem-se aos gnaisses migmatíticos. Foram realizadas datações U-Pb (LA-ICP-MS) em cristais de zircão do leucossoma Gx-77A2 (Tabelas 9.1 e 9.2) e do paleossoma Gx77B1 (Tabelas 9.3 e 9.4). Nos mesmos cristais de zircão, foram feitas análises isotópicas pontuais de Lu-Hf (Tabela 9.5). Para as mesmas amostras, foram obtidos dados isotópicos Sm-Nd e Rr-Sr em rochas total (Tabela 9).

Para o leucossoma duas populações de zircão foram observadas, uma com cristais prismáticos bipiramidados e outra isométrica e facetada do tipo soccer-ball, 
comuns em condições do fácies granulito (e.g. Vavra et al. 1999; Tichomirowa et al. 2005). Ambas as populações são translúcias e com raríssimas inclusões. Fraturas somente foram observadas nos cristais prismáticos. Os prismas ocorrem, predominantemente, como inclusões em cristais de hornblenda e biotita, enquanto que os cristais equidimensionais encontram-se na matriz, associados ao plagioclásio e à apatita. Em imagens de catodoluminescência (Figura 9.5), os cristais do tipo soccer-ball apresentam zoneamento setorizado com diferentes intensidades de luminescência. Os zircões 28.1 e 4.1 da Figura 9.5 mostram uma fina borda de sobrecrescimento com zoneamento oscilatório. Os dados analíticos de doze pontos concordantes do zircão do tipo soccer-ball, sem considerar os domínios oscilatórios, indicam uma idade concórdia de $608 \pm 4$ Ma (Figura 9.6).
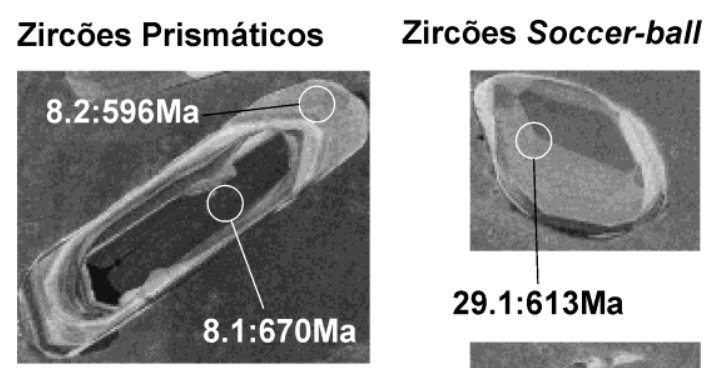

29.1:613Ma
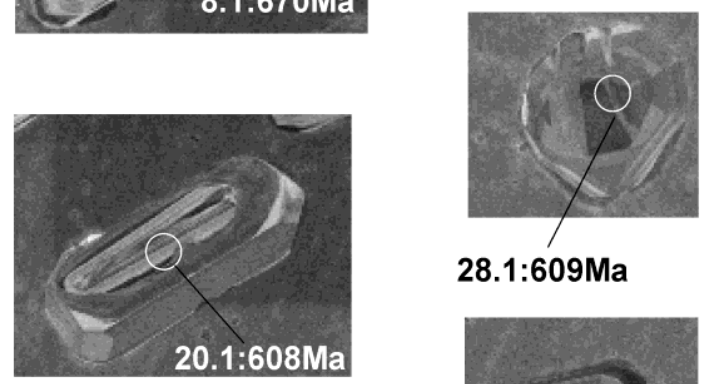

28.1:609Ma

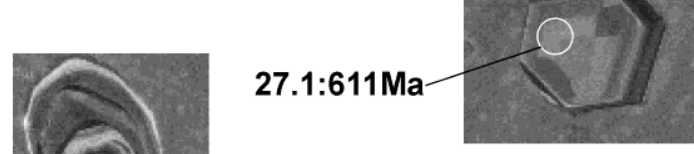

4.1:599Ma

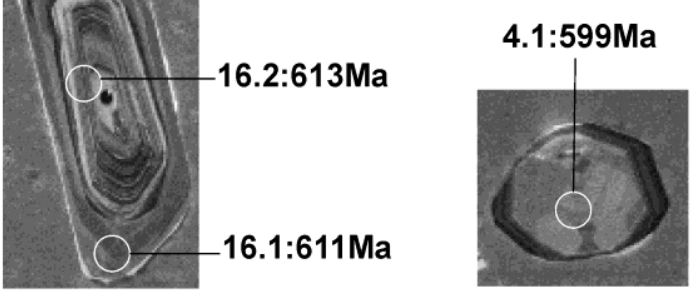

$0,5 \mathrm{~mm}$

Figura 9.5 - Imagens de catodoluminescência e tipologia dos zircões da amostra Gx-77A2 (leucossoma). Os círculos indicam o local de datação pontual U-Pb. As análises pontuais Lu-Hf seguem os mesmos pontos das análises $\mathrm{U}-\mathrm{Pb}$.

Os cristais prismáticos podem conter núcleos herdados aproximadamente homogêneos com baixa luminescência (ponto 8.1 na Figura 9.5), os quais apresentam idades pontuais mais antigas, entre 670 e 700 Ma. Sobre esse núcleo, 
crescem porções de luminescência mais alta com um zoneamento oscilatório e terminações piramidais, sendo seguido por um último sobrecrescimento homogêneo de maior luminescência (ponto 8.2 na Figura 9.5). Outro tipo de zircão prismático apresenta um núcleo de alta luminescência (ponto 20.1 na Figura 9.5) com um sobrecrescimento prismático de mais baixa intensidade. Um último tipo de zircão apresenta um núcleo com forte zoneamento oscilatório (ponto 16.2 na Figura 9.5) sobrecrescido por uma borda com zoneamento oscilatório incipiente (ponto 16.1 na Figura 9.5). A idade de núcleo e borda, nesse caso, é muito parecida. Os dados analíticos dos zircões prismáticos, 19 pontos concordantes, indicam uma idade de intercepto de $621 \pm 16 \mathrm{Ma}$ (Figura 9.6). Os dados concordantes excluem as idades mais antigas dos núcleos herdados de menor luminescência.
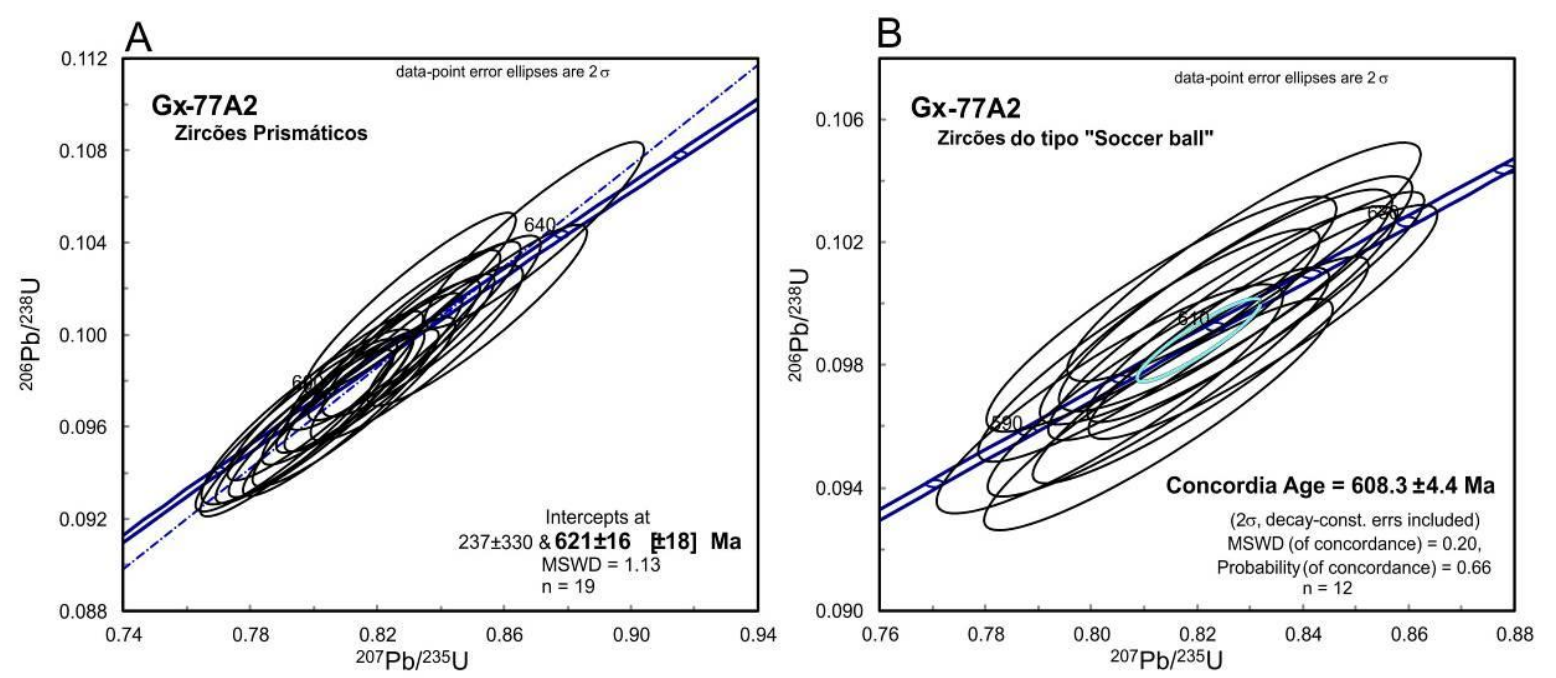

Figura 9.6 - (A) Diagrama concórdia com idade U-Pb (LA-ICP-MS) dos zircões prismáticos do leucossoma dos gnaisses migmatíticos da Unidade Metatexítica; (B) Diagrama concórdia com idade concórdia U-Pb (LA-ICP-MS) dos zircões isométricos (soccer-ball) do leucossoma dos gnaisses migmatíticos da Unidade Metatexítica.

O paleossoma apresenta duas populações principais de zircão, uma prismática bipiramidada e outra, de maior granulação, prismática a arredondada. Ambas as populações são translúcidas, sem inclusões e com quantidade moderada de fraturas. Em imagens de catodoluminescência (Figura 9.7), é possível distinguir três domínios com intensidades de luminescência distintos. O primeiro, tipicamente cinza escuro, ocorre em núcleos herdados mais antigos (e.g. pontos 7.2, 9.2 e 14.2 da Figura 9.7) e em zonas de sobrecrescimento sem zoneamento (e.g. ponto 26.1 da figura 9.7). Intensidades cinza claras (e.g pontos 2.2, 8.1, 8.2 e 18.1 na Figura 9.7), com idades mais jovens, apresentam zoneamentos oscilatórios (pontos $2.2 \mathrm{da}$ Figura 9.7) e, por vezes, convolutos (pontos 8.2 e 18.1 da Figura 9.7). Por fim, os domínios de maior luminescência apresentam-se como bordas de sobrecrescimento 
sem nenhum tipo de zoneamento. As idades desses domínios assemelham-se aos domínios cinza claros.

Quando tratados em conjunto, os dados analíticos de núcleos (domínios cinza escuro) e bordas (domínios cinza claro a brancos) dos cristais de zircão do paleossoma apresentam uma idade de intercepto de $640 \pm 28 \mathrm{Ma}$ (Figura 9.8A).
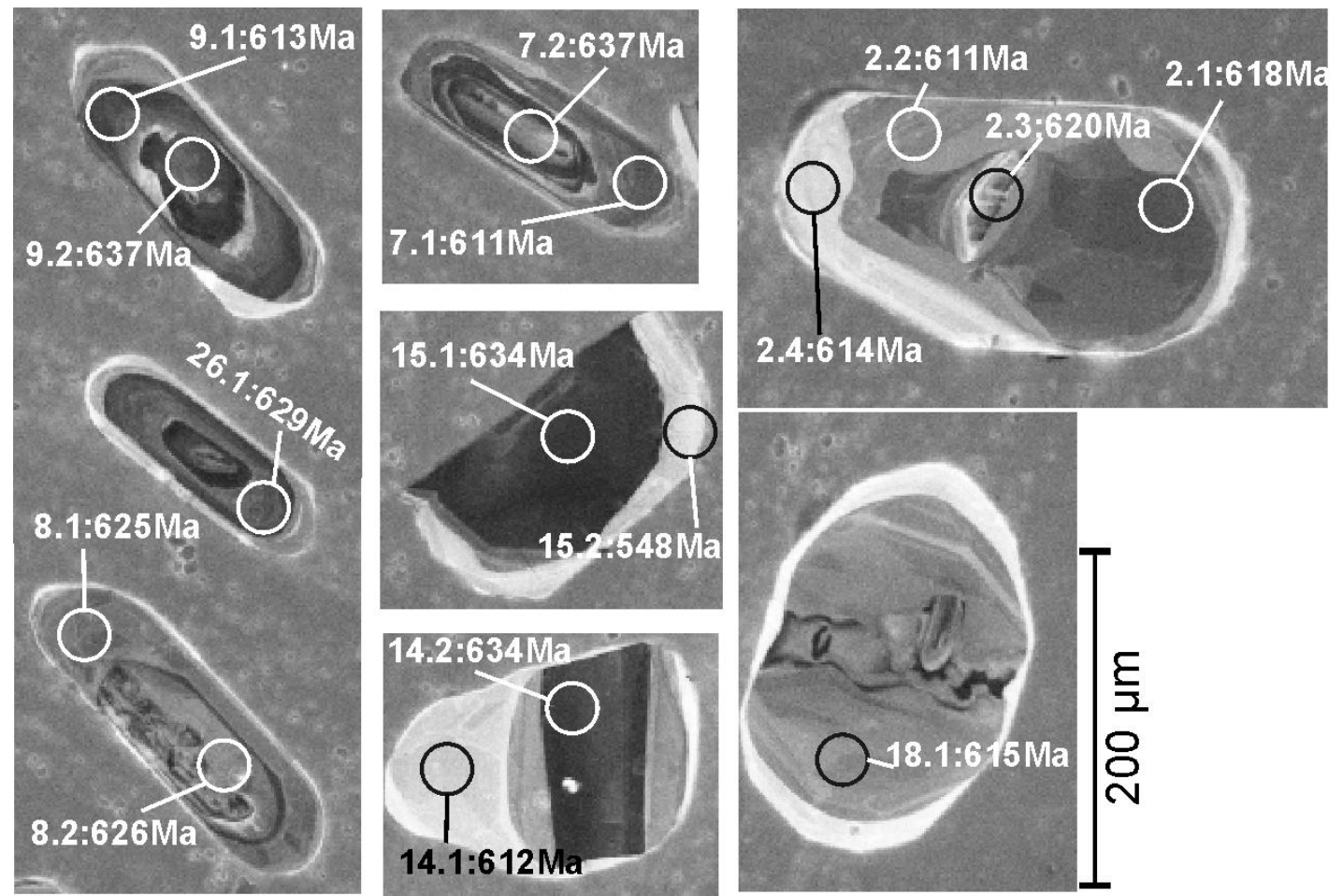

Figura 9.7 - Imagens de catodoluminescência dos cristais de zircão da amostra Gx-77B1 (paleossoma). Os círculos indicam o local de datação pontual U-Pb. As análises pontuais Lu-Hf seguem os mesmos pontos das análises $\mathrm{U}-\mathrm{Pb}$.

Quando tratados de forma separada, os dados não são concordantes e apresentam erros muito altos. Entretanto, o histograma das idades ${ }^{206} \mathrm{~Pb} /{ }^{238} \mathrm{U}$ apresenta dois picos principais, um em 639 Ma e outro em 614 Ma (Figura 9.8.B). As idades mais antigas referem-se aos domínios de mais baixa luminescência, enquanto que as idades mais jovens referem-se aos domínios mais claros, incluindo as bordas de sobrecrescimento.

A razão Th/U distingue bem os zircões do tipo soccer ball dos cristais prismáticos (Figura 9.9). É possível considerar como de origem metamórfica os cristais que apresentam razões $\mathrm{Th} / \mathrm{U}>0.1$ ou com grande variação dentro de seu espaço amostral (e.g. Carson et al. 2002; Kelly \& Harley 2005). Zircões metamórficos isométricos provenientes de líquidos anatéticos sin-tectônicos de alta temperatura tendem a mostrar razões Th/U entre 1.2 e 3.2 (Hokada \& Harley 2004). 

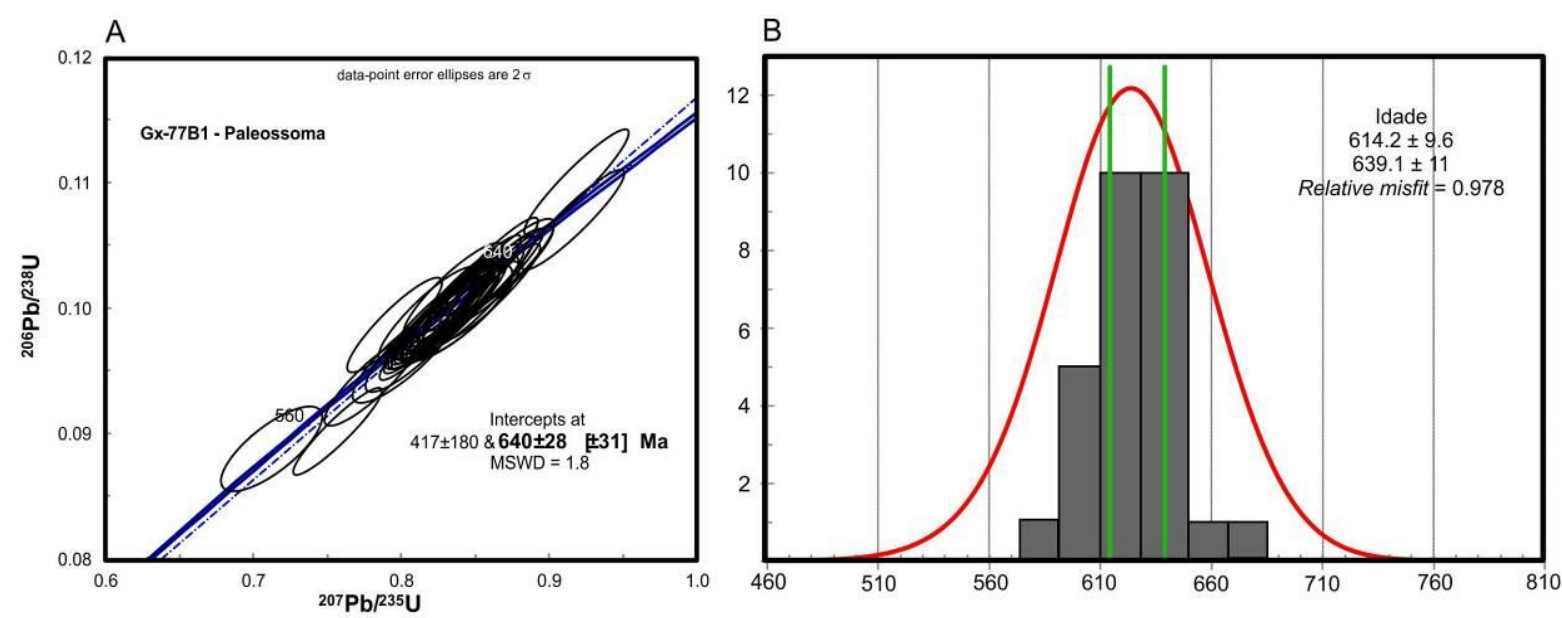

Figura 9.8 - (A) Diagrama concórdia com idade U-Pb (LA-ICP-MS) do paleossoma dos gnaisses migmatíticos da Unidade Metatexítica. Nesse caso, são utilizados todos os dados analíticos de núcleo e borda. Entretanto, a idade de intercepto aproxima-se das idades pontuais dos núcleos de baixa luminescência; (B) Histograma com idades ${ }^{206} \mathrm{~Pb} /{ }^{238} \mathrm{U}$ para o mesmo conjunto de zircões. O pico relativo à idade de $614.2 \pm 9.6$ Ma refere-se aos domínios de luminescência mais clara, enquanto que a idade de $639.0 \pm 11$ Ma indica a idade dos núcleos mais antigos de baixa luminescência.

De acordo com a Figura 9.9 é possível admitir que os cristais prismáticos do leucossoma tenham origem metamórfica devido a grande variação da razão Th/U (de 0.1 até 2.0) e que os zircões isométricos originaram-se a partir de líquidos anatéticos em altas temperaturas (Th/U entre 1.2 e 2.1). As bordas dos zircões do paleossoma também apresentam uma grande variação (entre 0.0 e 1.7), podendo refletir seu caráter metamórfico. Já os núcleos, apresentam razões de até 0.7 , possivelmente guardando alguma assinatura ígnea. Dessa forma, os dados isotópicos $\mathrm{Sm}-\mathrm{Nd}$ e $\mathrm{Rb}-\mathrm{Sr}$ de rocha total foram recalculados para a idade de $608 \mathrm{Ma}$, quando do evento anatético em fácies granulito (ver discussão no tópico 10.2).

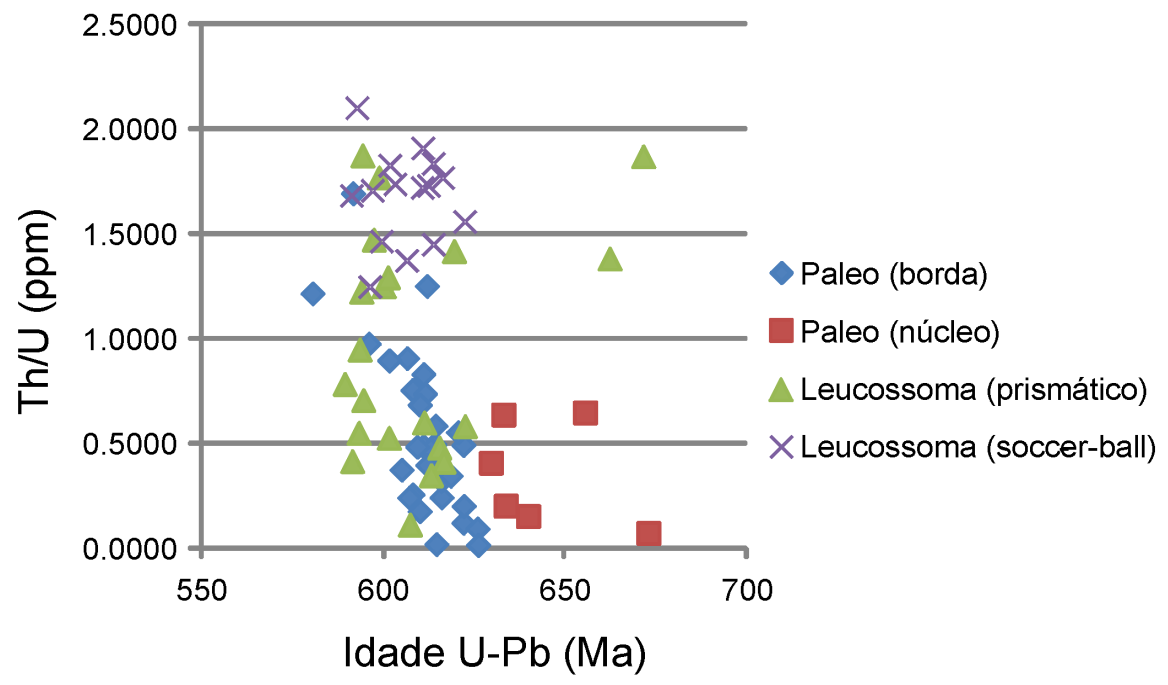

Figura 9.9 - Diagrama com razão Th/U vs. idades U-Pb. Observar a variação entre 0.1 e 2.0 para os zircões prismáticos do leucossoma. Os zircões isométricos apresentam valores $\mathrm{Th} / \mathrm{U}$ mais altos, entre 1.2 e 2.1 . As bordas dos zircões do paleossoma também apresentam uma boa variação, entre 0.0 e 1.7 , enquanto que os núcleos apresentam razões mais baixas e com pouca variação (ver texto para interpretações). 
O leucossoma e o paleossoma apresentam idades modelo $\left(T_{D M}\right)$ de residência crustal muito parecidas, em torno de $2.0 \mathrm{Ga}$ (Figura 9.10.A). O comportamento isotópico $\varepsilon_{\mathrm{Nd}(608)} e^{87} \mathrm{Sr}^{86} \mathrm{Sr}_{(608)}$ indica um caráter mais enriquecido do leucossoma em relação ao seu paleossoma. Os valores negativos de épsilon, de -11 e -13, e os valores da razão inicial de estrôncio, de 0.708 e 0.711 , indicam uma fonte crustal, sugestivamente retrabalhada (Figura 9.10.B).
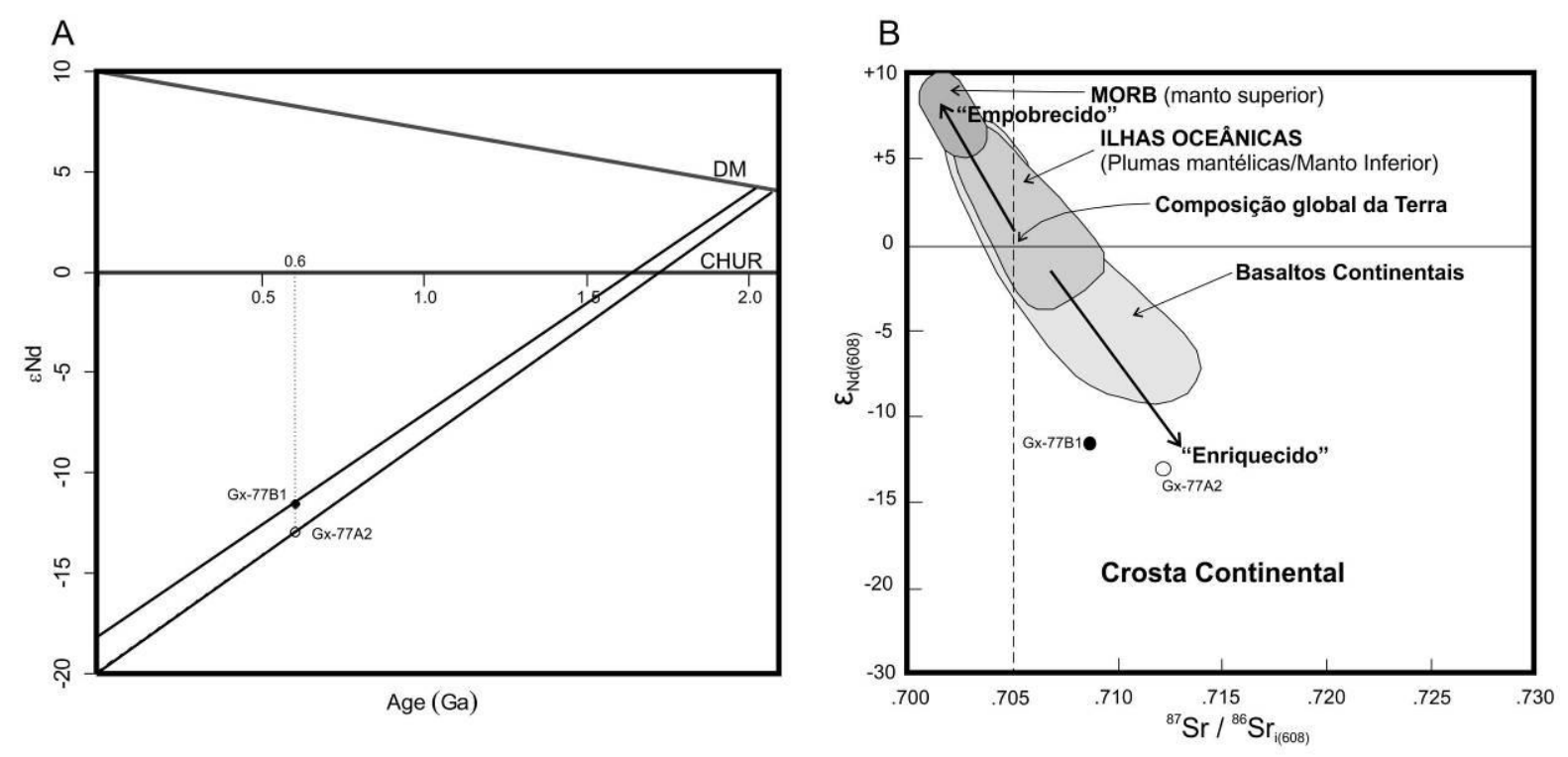

Figura 9.10 - (A) Valores de $\varepsilon_{N d}$ com idades modelo a partir das curvas de manto empobrecido (DM) e de reservatório condrítico não empobrecido (CHUR) para leucossoma (Gx-77A2) e paleossoma (Gx-77B1) da Unidade Metatexítica; (B) Diagrama com $\varepsilon_{\mathrm{Nd}(608)} \mathrm{vs} .{ }^{87} \mathrm{Sr}^{86} \mathrm{Sr}_{(608)}$ para as rochas metatexíticas recalculados para a idade de $608 \mathrm{Ma}$ (cf. Figura 9.6). As setas rotuladas "empobrecido" e "enriquecido", indicam, respectivamente, áreas-fonte enriquecidas em elementos compatíveis e incompatíveis.

Os dados isotópicos Lu-Hf pontuais obtidos nos cristais de zircão estão apresentados na Figura 9.11 e os resultados analíticos na Tabela 9.5. Os valores de $\varepsilon_{\mathrm{Hf}}$ dos zircões estão calculados para as idade pontuais $\mathrm{U}-\mathrm{Pb}$. Os zircões do paleossoma mais antigos (núcleos), por volta dos $640 \mathrm{Ma}$, apresentam valores de épsilon entre -5 e -10 e idades modelo $T_{D M}$ entre 1.8 e $2.0 \mathrm{Ga}$. Já os cristais mais jovens (bordas), por volta dos $610 \mathrm{Ma}$, variam de -7 até -17 , com idades modelo desde 1.8 até $2.5 \mathrm{Ga}$, mostrando maior residência crustal. Os valores de épsilon mais perto de -5 sugerem a contribuição de um reservatório um pouco mais empobrecido para os cristais do paleossoma, enquanto que os valores de até -17 dos cristais mais jovens possuem assinaturas da crosta continental inferior (Kinny \& Maas, 2003).

Os cristais do tipo soccer ball do leucossoma apresentam valores de $\varepsilon_{\mathrm{Hf}}$ de 12 até -21 , com idades modelo de 2.3 a $2.8 \mathrm{Ga}$. Já os cristais prismáticos apresentam $\varepsilon_{\mathrm{Hf}}$ entre -13 e -18 , com idades modelo entre 2.3 e $2.7 \mathrm{Ga}$. O cristal de 
épsilon -26 e idade modelo de 3.19 Ga representa um núcleo herdado. Os cristais isométricos apresentam maior residência crustal e os valores de épsilon de até -21 podem indicar fontes um pouco mais enriquecidas, sugestivamente a crosta continental intermediária. $O \varepsilon_{H f}$ de -26 para o núcleo herdado e sua longa residência crustal podem sugerir uma fonte enriquecida e fortemente retrabalhada. Entretando, Kinny \& Maars (op. cit.) afirmam que valores de épsilon fortemente negativos (i.e. muito enriquecido em Hf) podem ter como fonte uma crosta oceânica em subducção.

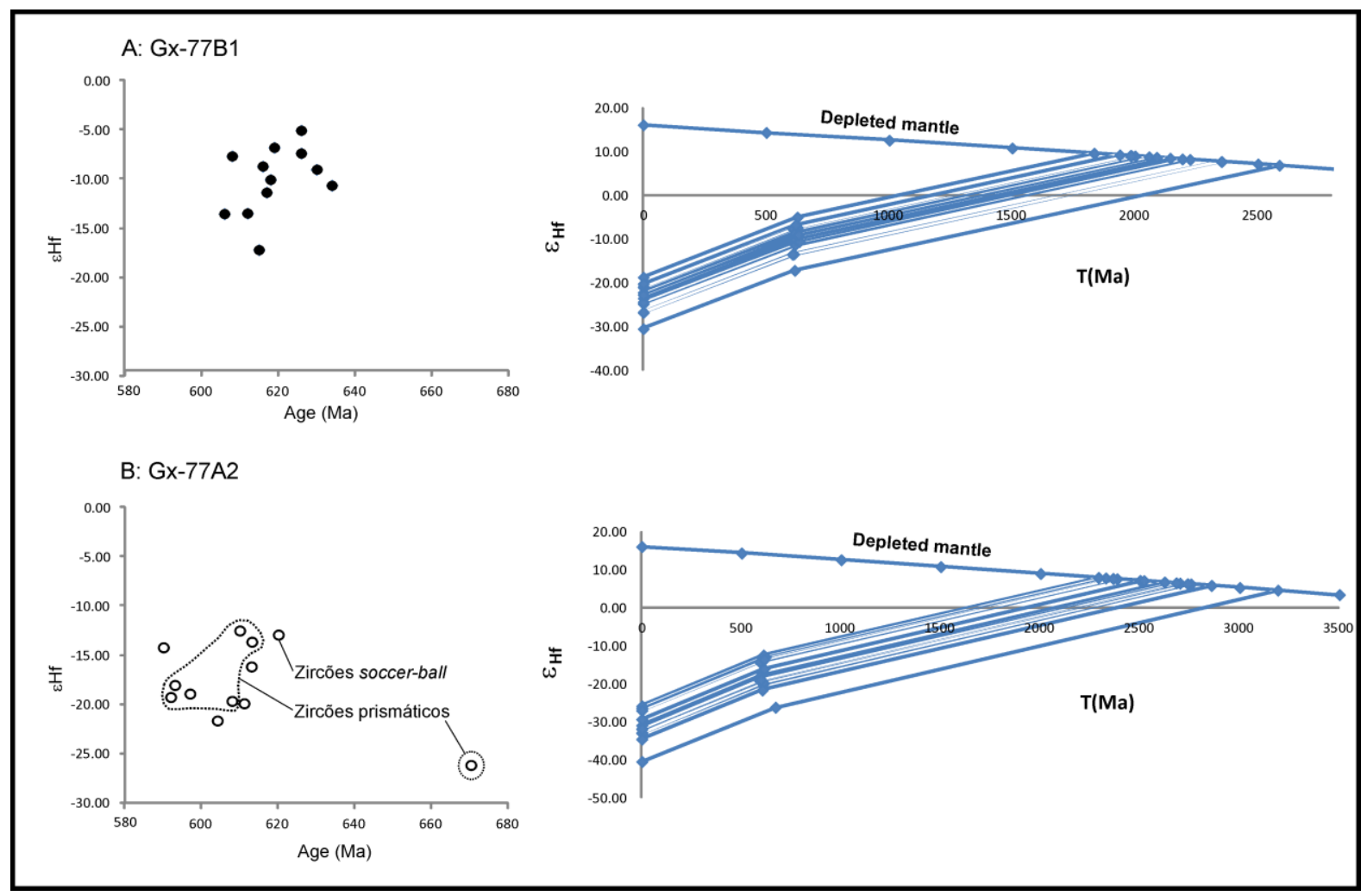

Figura 9.11 - Valores de $\varepsilon_{\mathrm{Hf}}$ calculados para as idades pontuais de U-Pb e valores das idades modelo $\mathrm{T}_{\mathrm{DM}(\mathrm{Hf})}$ por duplo-estágio (ver texto), respectivamente, para o paleossoma Gx-77B1 e leucossoma Gx-77A2.

As idades modelo de $\mathrm{Hf}$ pontuais mostraram-se bem mais antigas do que as idades modelo de Nd em rocha total. Nedel et al. (2007) discutem essas diferenças e afirmam que a maior parte das idades modelo obtidas em rocha total são, na verdade, a média do tempo de residência crustal. $\mathrm{O}$ fato da análise de Hf pontual poder ser estudada com as idades pontuais U-Pb conhecidas, permite o cálculo de idades modelo por duplo-estágio.

O núcleo herdado nos zircões do paleossoma apresenta a idade modelo mais antiga, de 3.19 Ga, enquanto que todos os outros variam entre $2-2.5 \mathrm{Ga}$. Dessa forma, é possível sugerir que as idades mais antigas são as que mais se aproximam à idade de formação da crosta continental hospedeira desse zircão. Por outro lado, 
as idades modelo de $\mathrm{Hf}$ mais jovens entre $2-2.5 \mathrm{Ga}$, concordantes com as idades modelo de $\mathrm{Nd}$ em torno de $2.05 \mathrm{Ga}$, podem indicar retrabalhamento crustal. Em uma correlação mais regional, a idade inferida como de formação da crosta continental está de acordo com um dos dois principais pulsos de formação da crosta continental do supercontinente Gondwana, por volta de 3.3 Ga (Kemp et al., 2006) 
Tabela 9 - Dados isotópicos Sm-Nd e Rb-Sr para as rochas da porção sul-ocidental do lobo Guaxupé.

\begin{tabular}{|c|c|c|c|c|c|c|c|c|c|c|c|c|}
\hline \multicolumn{13}{|c|}{ Unidade Granulítica Basal } \\
\hline Gx-76K & 53.5 & 322.9 & 0.117 & 0.70854 & 0.707468 & 6.136 & 43.713 & 0.0849 & 0.51168 & -18.69 & 1.668 & -9.56 \\
\hline \multicolumn{10}{|c|}{ Unidade Diatexítica (SJRP) } & & & \\
\hline & \multicolumn{5}{|c|}{$\mathbf{R b}(\mathbf{p p m}) \mathrm{Sr}(\mathrm{ppm})^{8}$} & Sm (ppm) & Nd (ppm) & ${ }^{147} \mathrm{Sm}^{144} \mathrm{Nd}$ & ${ }^{143} \mathrm{Nd} /{ }^{144} \mathrm{Nd}$ & $\varepsilon N d(0)$ & $T_{D M}(G a)$ & $\varepsilon N d_{(628)}$ \\
\hline Gx-78A & 75.9 & 462.9 & 0.475 & 0.71134 & 0.707081 & 7.033 & 36.144 & 0.1177 & 0.511796 & -16.42 & 2.03 & -10.1 \\
\hline \multicolumn{13}{|c|}{ Unidade Diatexítica (Pinhal) } \\
\hline & \multicolumn{5}{|c|}{$\mathrm{Rb}(\mathrm{ppm}) \mathrm{Sr}(\mathrm{ppm})^{8}$} & Sm (ppm) & Nd (ppm) & ${ }^{147} \mathrm{Sm}^{144} \mathrm{Nd}$ & ${ }^{143} \mathrm{Nd} /{ }^{144} \mathrm{Nd}$ & $\varepsilon N d(0)$ & $T_{D M}(G a)$ & $\varepsilon N d_{(625)}$ \\
\hline Gx-76E & 190.5 & 664.2 & 0.831 & 0.71413 & 0.706717 & 6.644 & 51.584 & 0.0779 & 0.511661 & -19.06 & 1.675 & -9.58 \\
\hline Gx-22C & 65.3 & 2034.1 & 0.093 & 0.70836 & 0.707526 & 11.208 & 61.798 & 0.1097 & 0.511836 & -15.65 & 1.82 & -8.71 \\
\hline \multicolumn{13}{|c|}{ Unidade Metatexítica } \\
\hline
\end{tabular}


Tabela 9.1 - Resultados das análises U-Pb para os zircões prismáticos do leucossoma. Em cinza destacam-se os dados utilizados no cálculo de idades.

\begin{tabular}{|c|c|c|c|c|c|c|c|c|c|c|c|c|c|c|c|c|}
\hline \multicolumn{17}{|c|}{ Unidade Metatexítica - Leucossoma (Gx-77A2) - Zircões prismáticos } \\
\hline \multicolumn{10}{|c|}{ Razões Isotópicas } & \multicolumn{7}{|c|}{ Idades (Ma) } \\
\hline Ponto & ${ }^{207} \mathrm{~Pb}$ (cps) & $\mathrm{Th} / \mathrm{U}$ & ${ }^{207} \mathrm{~Pb} /{ }^{206} \mathrm{~Pb}$ & $2 \sigma$ & ${ }^{207} \mathrm{~Pb} /{ }^{235} \mathrm{U}$ & $2 \sigma$ & ${ }^{206} \mathrm{~Pb} /{ }^{238} \mathrm{U}$ & $2 \sigma$ & Rho & ${ }^{206} \mathrm{~Pb} /{ }^{238} \mathrm{U}$ & $2 \sigma$ & ${ }^{207} \mathrm{~Pb} /{ }^{235} \mathrm{U}$ & $2 \sigma$ & ${ }^{207} \mathrm{~Pb} /{ }^{206} \mathrm{~Pb}$ & $2 \sigma$ & Disc. (\%) \\
\hline 1.1 & 9103 & 0.7112 & 0.06140 & 0.00070 & 0.808586487 & 0.025186 & 0.09660698 & 0.00296 & 0.931 & 594 & 17 & 602 & 14 & 653 & 25 & 9.4 \\
\hline 2.1 & 7089 & 0.789 & 0.06068 & 0.00072 & 0.794670493 & 0.024982 & 0.09573367 & 0.002944 & 0.927 & 589 & 17 & 594 & 14 & 628 & 26 & 6.4 \\
\hline 2.2 & 7450 & 0.531 & 0.06211 & 0.00075 & 0.832278313 & 0.026302 & 0.09780697 & \begin{tabular}{|l|}
0.003021 \\
\end{tabular} & 0.926 & 602 & 18 & 615 & 14 & 678 & 26 & 11.8 \\
\hline 7.1 & 7410 & 1.879 & 0.06069 & 0.00071 & 0.8041138 & 0.025173 & 0.09657144 & 0.002965 & 0.929 & 594 & 17 & 599 & 14 & 628 & 25 & 5.7 \\
\hline 8.1 & 18695 & 1.874 & 0.06279 & 0.00099 & 0.942197395 & 0.034153 & 0.10976757 & 0.003747 & 0.901 & 671 & 22 & 674 & 18 & 701 & 34 & 4.5 \\
\hline 8.2 & 4705 & 1.477 & 0.06040 & 0.00076 & 0.812681849 & 0.026002 & 0.09709891 & 0.003014 & 0.920 & 597 & 18 & 604 & 14 & 618 & 27 & 3.5 \\
\hline 11.1 & 6327 & 1.774 & 0.06044 & 0.00073 & 0.803584052 & 0.025285 & 0.09733973 & 0.00299 & 0.924 & 599 & 18 & 599 & 14 & 619 & 26 & 3.5 \\
\hline 12.1 & 9976 & 1.3868 & 0.06120 & 0.00084 & 0.902213482 & 0.029986 & 0.10818297 & 0.003445 & 0.911 & 662 & 20 & 653 & 16 & 646 & 30 & -2.6 \\
\hline 12.2 & 4887 & 1.298 & 0.05902 & 0.00108 & 0.782092434 & 0.027912 & 0.09775669 & 0.003152 & 0.860 & 601 & 18 & 587 & 16 & 568 & 40 & -6.2 \\
\hline 14.1 & 13904 & 0.118 & 0.06032 & 0.00076 & 0.823896089 & 0.026922 & 0.0987881 & 0.003139 & 0.924 & 607 & 18 & 610 & 15 & 615 & 27 & 1.3 \\
\hline 15.1 & 13333 & 0.587 & 0.06004 & 0.00076 & 0.83043833 & 0.027236 & 0.10136387 & 0.003228 & 0.923 & 622 & 19 & 614 & 15 & 605 & 28 & -3.0 \\
\hline 16.1 & 11229 & 0.485 & 0.06042 & 0.00077 & 0.831738028 & 0.027275 & 0.10016618 & 0.003187 & 0.922 & 615 & 19 & 615 & 15 & 619 & 28 & 0.6 \\
\hline 16.2 & 9216 & 0.418 & 0.06048 & 0.00087 & 0.837091393 & 0.028124 & 0.10036479 & 0.003205 & 0.904 & 617 & 19 & 618 & 15 & 621 & 31 & 0.7 \\
\hline 17.1 & 14005 & 1.422 & 0.06101 & 0.00081 & 0.851647225 & 0.02821 & 0.10085502 & \begin{tabular}{|l|}
0.003226 \\
\end{tabular} & 0.918 & 619 & 19 & 626 & 15 & 640 & 28 & 3.3 \\
\hline 17.2 & 4702 & 0.953 & 0.06095 & 0.00094 & 0.79795095 & 0.027302 & 0.09643665 & \begin{tabular}{|l|}
0.003101 \\
\end{tabular} & 0.895 & 593 & 18 & 596 & 15 & 637 & 33 & 7.2 \\
\hline 18.1 & 13022 & 0.421 & 0.06010 & 0.00076 & 0.794363623 & 0.025997 & 0.09608947 & 0.003055 & 0.923 & 591 & 18 & 594 & 15 & 607 & 27 & 2.7 \\
\hline 19.1 & 9954 & 0.353 & 0.06019 & 0.00081 & 0.825289388 & 0.027339 & 0.099777966 & 0.003183 & 0.916 & 613 & 19 & 611 & 15 & 611 & 29 & -0.4 \\
\hline 20.1 & 6778 & 0.604 & 0.05967 & 0.00090 & 0.816424153 & 0.027893 & 0.09945929 & 0.003203 & 0.897 & 611 & 19 & 606 & 15 & 591 & 33 & -3.5 \\
\hline 21.1 & 5497 & 1.229 & 0.05985 & 0.00090 & 0.772659459 & 0.026252 & 0.09651578 & \begin{tabular}{|l|}
0.003094 \\
\end{tabular} & 0.898 & 594 & 18 & 581 & 15 & 598 & 33 & 0.7 \\
\hline 25.1 & 6700 & 1.558 & 0.06129 & 0.00085 & 0.832508342 & 0.02725 & 0.09920622 & \begin{tabular}{|l|}
0.003102 \\
\end{tabular} & 0.907 & 610 & 18 & 615 & 15 & 650 & 30 & 6.4 \\
\hline 30.1 & 11723 & 0.158 & 0.06060 & 0.00079 & 0.869353073 & 0.028282 & 0.10433893 & 0.00328 & 0.918 & 640 & 19 & 635 & 15 & 625 & 28 & -2.5 \\
\hline 34.1 & 14150 & 0.843 & 0.06061 & 0.00075 & 0.82048246 & 0.02627 & 0.09862673 & 0.003072 & 0.923 & 606 & 18 & 608 & 15 & 625 & 27 & 3.2 \\
\hline
\end{tabular}


Tabela 9.2 - Resultados das análises U-Pb dos zircões isométricos do leucossoma. Em cinza destacam-se os dados utilizados no cálculo de idades.

Unidade Metatexítica - Leucossoma (Gx-77A2) - Zircões do tipo soccer-ball

\begin{tabular}{|c|c|c|c|c|c|c|c|c|c|c|c|c|c|c|c|c|}
\hline \multicolumn{10}{|c|}{ Razões Isotópicas } & \multicolumn{7}{|c|}{ Idades (Ma) } \\
\hline Ponto & ${ }^{207} \mathrm{~Pb}$ (cps) & $\mathrm{Th} / \mathrm{U}$ & ${ }^{207} \mathrm{~Pb} /{ }^{206} \mathrm{~Pb}$ & $2 \sigma$ & ${ }^{207} \mathrm{~Pb} /{ }^{235} \mathrm{U}$ & $2 \sigma$ & ${ }^{206} \mathrm{~Pb} /{ }^{238} \mathrm{U}$ & $2 \sigma$ & Rho & ${ }^{206} \mathrm{~Pb} /{ }^{238} \mathrm{U}$ & $2 \sigma$ & ${ }^{207} \mathrm{~Pb} /{ }^{235} \mathrm{U}$ & $2 \sigma$ & ${ }^{207} \mathrm{~Pb} /{ }^{206} \mathrm{~Pb}$ & $2 \sigma$ & Disc. (\%) \\
\hline 3.1 & 5953 & 1.688 & 0.06184 & 0.00074 & 0.817463077 & \begin{tabular}{|l|}
0.025763 \\
\end{tabular} & \begin{tabular}{|l|}
0.09605514 \\
\end{tabular} & \begin{tabular}{|l|}
0.002958 \\
\end{tabular} & 0.926 & 591 & 17 & 607 & 14 & 669 & 26 & 12.1 \\
\hline 4.1 & 5813 & 1.832 & 0.06088 & 0.00075 & 0.820743132 & 0.025937 & 0.0978446 & 0.003014 & 0.923 & 602 & 18 & 608 & 14 & 635 & 26 & 5.5 \\
\hline 5.1 & 8169 & 1.841 & 0.06100 & 0.00073 & 0.831121372 & 0.026083 & 0.09988136 & 0.003068 & 0.927 & 614 & 18 & 614 & 14 & 639 & 26 & 4.2 \\
\hline 6.1 & 5305 & 1.254 & 0.06206 & 0.00076 & 0.820994325 & 0.026018 & 0.09756495 & 0.003016 & 0.924 & 600 & 18 & 609 & 14 & 676 & 26 & 11.8 \\
\hline 9.1 & 8650 & 2.017 & 0.06046 & 0.00073 & 0.799915806 & 0.025115 & 0.09631062 & 0.002954 & 0.925 & 593 & 17 & 597 & 14 & 620 & 26 & 4.6 \\
\hline 10.1 & 5435 & 1.742 & 0.06051 & 0.00074 & 0.815343806 & 0.025816 & 0.09809265 & \begin{tabular}{|c|}
0.003031 \\
\end{tabular} & 0.925 & 603 & 18 & 605 & 14 & 622 & 26 & 3.2 \\
\hline 13.1 & 8650 & 0.555 & 0.06142 & 0.00083 & 0.81269593 & 0.026942 & 0.09639335 & 0.003071 & 0.914 & 593 & 18 & 604 & 15 & 654 & 29 & 9.7 \\
\hline 22.1 & 5753 & 1.253 & 0.06066 & 0.00091 & 0.80350971 & 0.026839 & 0.09690826 & 0.003047 & 0.894 & 596 & 18 & 599 & 15 & 627 & 32 & 5.2 \\
\hline 23.1 & 6968 & 1.47 & 0.06060 & 0.00080 & 0.812669429 & 0.026382 & \begin{tabular}{|l|l|}
0.09745398 \\
\end{tabular} & 0.003048 & 0.914 & 599 & 18 & 604 & 15 & 625 & 29 & 4.3 \\
\hline 24.1 & 4711 & 1.713 & 0.06019 & 0.00094 & 0.830848825 & 0.028 & 0.09703007 & 0.003059 & 0.888 & 597 & 18 & 614 & 15 & 611 & 34 & 2.3 \\
\hline 25.1 & 6699 & 1.558 & 0.06129 & 0.00085 & 0.832508342 & 0.02725 & 0.09920622 & 0.003102 & 0.907 & 610 & 18 & 615 & 15 & 650 & 30 & 6.4 \\
\hline 26.1 & 7612 & 1.726 & 0.06078 & 0.00083 & 0.824728989 & \begin{tabular}{|l|}
0.026895 \\
\end{tabular} & \begin{tabular}{|l|}
0.09937047 \\
\end{tabular} & \begin{tabular}{|l|l|}
0.003109 \\
\end{tabular} & 0.910 & 611 & 18 & 611 & 15 & 631 & 29 & 3.4 \\
\hline 27.1 & 5312 & 1.736 & 0.05966 & 0.00088 & 0.813322033 & 0.027024 & 0.09965817 & 0.003131 & 0.898 & 612 & 18 & 604 & 15 & 591 & 32 & -3.7 \\
\hline 28.1 & 7681 & 1.915 & 0.06141 & 0.00081 & 0.832399999 & 0.02697 & 0.09938885 & 0.003107 & 0.915 & 611 & 18 & 615 & 15 & 653 & 28 & 6.8 \\
\hline 29.1 & 6147 & 1.774 & 0.06008 & 0.00088 & 0.82724882 & 0.02735 & 0.10031736 & 0.003139 & 0.898 & 616 & 18 & 612 & 15 & 606 & 32 & -1.7 \\
\hline 31.1 & 6690 & 1.564 & 0.06032 & 0.00086 & 0.828801816 & 0.027329 & 0.10135822 & 0.003178 & 0.903 & 622 & 19 & 613 & 15 & 615 & 31 & -1.3 \\
\hline 32.1 & 7835 & 1.378 & 0.06028 & 0.00081 & 0.810840717 & 0.026386 & 0.0986351 & 0.003084 & 0.912 & 606 & 18 & 603 & 15 & 614 & 29 & 1.3 \\
\hline 33.1 & 6546 & 1.455 & 0.05982 & 0.00087 & 0.823537204 & 0.027266 & 0.09988716 & 0.003131 & 0.899 & 614 & 18 & 610 & 15 & 597 & 32 & -2.9 \\
\hline
\end{tabular}


Tabela 9.3 - Resultados das análises U-Pb para as bordas dos zircões do paleossoma. Em cinza destacam-se os dados utilizados no cálculo de idades.

\begin{tabular}{|c|c|c|c|c|c|c|c|c|c|c|c|c|c|c|c|c|}
\hline \multicolumn{17}{|c|}{ Unidade Metatexítica - Paleossoma (Gx-77B1) - Domínios cinza claro a brancos (bordas) } \\
\hline \multicolumn{10}{|c|}{ Razões Isotópicas } & \multicolumn{7}{|c|}{ Idades (Ma) } \\
\hline Ponto & ${ }^{207} \mathrm{~Pb}(\mathrm{cps})$ & Th/U & ${ }^{207} \mathrm{~Pb} /{ }^{206} \mathrm{~Pb}$ & $2 \sigma$ & ${ }^{207} \mathrm{~Pb} /{ }^{235} \mathrm{U}$ & $2 \sigma$ & ${ }^{206} \mathrm{~Pb} /{ }^{238} \mathrm{U}$ & $2 \sigma$ & Rho & ${ }^{206} \mathrm{~Pb} /{ }^{238} \mathrm{U}$ & $2 \sigma$ & ${ }^{207} \mathrm{~Pb} / /^{235} \mathrm{U}$ & $2 \sigma$ & ${ }^{207} \mathrm{~Pb} /{ }^{206} \mathrm{~Pb}$ & $2 \sigma$ & Disc. (\%) \\
\hline 2.2 & 12475 & 0.491 & 0.06086 & 0.00095 & 0.83242732 & 0.027515 & 0.09937964 & 0.003064 & 0.884 & 611 & 18 & 615 & 15 & 634 & 34 & 3.9 \\
\hline 2.4 & 3409 & 1.256 & 0.06043 & 0.00123 & 0.83746218 & 0.030409 & 0.09956724 & 0.00315 & 0.828 & 612 & 18 & 618 & 17 & 619 & 44 & 1.2 \\
\hline 3.1 & 19745 & 0.126 & 0.06092 & 0.00095 & \begin{tabular}{|l|}
0.84892746 \\
\end{tabular} & 0.028042 & 0.10131882 & 0.003121 & 0.883 & 622 & 18 & 624 & 15 & 636 & 33 & 2.4 \\
\hline 5.1 & 19944 & 0.247 & 0.06096 & 0.00094 & 0.83713151 & 0.027626 & 0.1002021 & 0.00309 & 0.885 & 616 & 18 & 618 & 15 & 638 & 33 & 3.6 \\
\hline 6.1 & 11202 & 0.981 & 0.06004 & 0.00099 & 0.80851838 & 0.027147 & 0.09692177 & 0.002996 & 0.872 & 596 & 18 & 602 & 15 & 605 & 36 & 1.5 \\
\hline 6.2 & 6946 & 0.836 & 0.06042 & 0.00098 & 0.81795243 & 0.027549 & 0.09946507 & 0.0031 & 0.878 & 611 & 18 & 607 & 15 & 619 & 35 & 1.2 \\
\hline 8.1 & 18922 & 0.497 & 0.06028 & 0.00094 & \begin{tabular}{|l|}
0.83499741 \\
\end{tabular} & 0.02762 & 0.10137014 & 0.00313 & 0.885 & 622 & 18 & 616 & 15 & 614 & 34 & -1.5 \\
\hline 8.2 & 18530 & 0.2063 & 0.06178 & 0.00072 & \begin{tabular}{|l|l|}
0.86084798 \\
\end{tabular} & 0.02696 & 0.10130929 & 0.003113 & 0.929 & 622 & 18 & 631 & 15 & 667 & 25 & 7.0 \\
\hline 10.1 & 13592 & 0.402 & 0.06039 & 0.00073 & 0.83196301 & 0.026096 & 0.09960269 & 0.00305 & 0.924 & 612 & 18 & 615 & 14 & 618 & 26 & 0.9 \\
\hline 12.1 & 4045 & 1.698 & 0.06032 & 0.00115 & 0.80215406 & 0.028529 & 0.09612515 & \begin{tabular}{|l|}
0.003045 \\
\end{tabular} & 0.846 & 592 & 18 & 598 & 16 & 615 & 41 & 4.0 \\
\hline 14.1 & 5623 & 0.912 & 0.05985 & 0.00087 & \begin{tabular}{|l|}
0.79546537 \\
\end{tabular} & 0.026131 & 0.09864882 & 0.003069 & 0.898 & 606 & 18 & 594 & 15 & 598 & 31 & -1.5 \\
\hline 15.2 & 3715 & 1.983 & 0.05718 & 0.00147 & 0.71196911 & 0.027905 & 0.08874984 & 0.00277 & 0.756 & 548 & 16 & 546 & 16 & 499 & 57 & -10.4 \\
\hline 17.1 & 4886 & 1.22 & 0.05926 & 0.00097 & \begin{tabular}{|l|}
0.78005805 \\
\end{tabular} & 0.026326 & 0.09423737 & 0.002939 & 0.877 & 581 & 17 & 586 & 15 & 577 & 35 & -0.7 \\
\hline 18.1 & 10547 & 0.589 & 0.06089 & 0.00075 & 0.83681122 & 0.026015 & 0.09998458 & 0.003026 & 0.920 & 614 & 18 & 617 & 14 & 636 & 26 & 3.5 \\
\hline 19.1 & 13693 & 0.719 & 0.06131 & 0.00075 & \begin{tabular}{|l|l|}
0.75659007 \\
\end{tabular} & 0.024549 & 0.09014159 & \begin{tabular}{|l|}
0.002856 \\
\end{tabular} & 0.928 & 556 & 17 & 572 & 14 & 650 & 26 & 15.1 \\
\hline 21.1 & 10070 & 0.689 & 0.06049 & 0.00074 & 0.82652393 & 0.025607 & 0.09925437 & 0.002997 & 0.921 & 610 & 18 & 612 & 14 & 621 & 26 & 1.9 \\
\hline 27.1 & 14134 & 0.558 & 0.06014 & 0.00072 & 0.83838341 & 0.025877 & 0.10103652 & 0.003046 & 0.923 & 620 & 18 & 618 & 14 & 609 & 26 & -2.0 \\
\hline 28.1 & 21092 & 0.35 & 0.06024 & 0.00070 & 0.83716126 & 0.025753 & 0.10069841 & 0.003037 & 0.926 & 619 & 18 & 618 & 14 & 612 & 25 & -1.1 \\
\hline
\end{tabular}


Tabela 9.4 - Resultados das análises U-Pb nos núcleos dos zircões do paleossoma. Em cinza destacam-se os dados utilizados no cálculo de idades.

Unidade Metatexítica - Paleossoma (Gx-77B1) - Domínio cinza escuro (núcleos)

\begin{tabular}{|c|c|c|c|c|c|c|c|c|c|c|c|c|c|c|c|c|}
\hline \multicolumn{10}{|c|}{ Razões Isotópicas } & \multicolumn{7}{|c|}{ Idades (Ma) } \\
\hline Ponto & ${ }^{207} \mathrm{~Pb}$ (cps) & Th/U & ${ }^{207} \mathrm{~Pb} /{ }^{206} \mathrm{~Pb}$ & $2 \sigma$ & ${ }^{207} \mathrm{~Pb} /{ }^{235} \mathrm{U}$ & $2 \sigma$ & ${ }^{206} \mathrm{~Pb} /{ }^{238} \mathrm{U}$ & $2 \sigma$ & Rho & ${ }^{206} \mathrm{~Pb} /{ }^{238} \mathrm{U}$ & $2 \sigma$ & ${ }^{207} \mathrm{~Pb} /{ }^{235} \mathrm{U}$ & $2 \sigma$ & ${ }^{207} \mathrm{~Pb} /{ }^{206} \mathrm{~Pb}$ & $2 \sigma$ & Disc. (\%) \\
\hline 1.1 & 29055 & 0.7599 & 0.05994 & 0.00093 & 0.82165102 & 0.027091 & 0.0988845 & 0.003044 & 0.884 & 608 & 18 & 609 & 15 & 601 & 33 & -1.1 \\
\hline 2.1 & 24996 & 0.5 & 0.06043 & 0.00094 & 0.84578573 & 0.027928 & 0.09992209 & 0.003078 & 0.884 & 614 & 18 & 622 & 15 & 619 & 34 & 0.8 \\
\hline 2.3 & 10722 & 0.388 & 0.06154 & 0.00096 & 0.84514743 & 0.028101 & 0.10034073 & 0.003112 & 0.884 & 616 & 18 & 622 & 15 & 658 & 33 & 6.6 \\
\hline 4.1 & 26530 & 0.478 & 0.06087 & 0.00094 & 0.83341448 & 0.027479 & 0.09977527 & 0.003073 & 0.885 & 613 & 18 & 616 & 15 & 635 & 33 & 3.6 \\
\hline 7.1 & 23105 & 0.261 & 0.06034 & 0.00093 & 0.82403337 & 0.027166 & 0.09884553 & 0.003046 & 0.885 & 608 & 18 & 610 & 15 & 616 & 33 & 1.4 \\
\hline 7.2 & 31488 & 0.643 & 0.06119 & 0.00094 & \begin{tabular}{|l|}
0.86852767 \\
\end{tabular} & 0.028715 & 0.10316997 & 0.003191 & 0.887 & 633 & 19 & 635 & 15 & 646 & 33 & 2.1 \\
\hline 9.1 & 31966 & 0.182 & 0.06098 & 0.00070 & 0.83419847 & 0.025894 & 0.09924872 & 0.003031 & 0.931 & 610 & 18 & 616 & 14 & 638 & 25 & 4.7 \\
\hline 9.2 & 33707 & 0.207 & 0.06041 & 0.00070 & 0.85979743 & 0.026814 & 0.10328556 & 0.003167 & 0.931 & 634 & 18 & 630 & 15 & 618 & 25 & -2.6 \\
\hline 11.1 & 48676 & 0.077 & 0.06092 & 0.00069 & 0.91814306 & 0.028888 & 0.1100124 & 0.00341 & 0.934 & 673 & 20 & 661 & 15 & 636 & 24 & -6.1 \\
\hline 13.1 & 25052 & 0.489 & 0.05994 & 0.00068 & 0.82463939 & 0.025603 & 0.09913231 & 0.003029 & 0.931 & 609 & 18 & 611 & 14 & 601 & 25 & -1.4 \\
\hline 14.2 & 25167 & 0.413 & 0.06105 & 0.00071 & \begin{tabular}{|l|l|}
0.86902882 \\
\end{tabular} & 0.027182 & 0.10259254 & 0.003152 & 0.930 & 630 & 18 & 635 & 15 & 641 & 25 & 1.9 \\
\hline 15.1 & 69951 & 0.327 & 0.06025 & 0.00068 & 0.83394107 & 0.025831 & 0.10024767 & 0.003062 & 0.933 & 616 & 18 & 616 & 14 & 613 & 24 & -0.5 \\
\hline 16.1 & 33271 & 0.099 & 0.06032 & 0.00068 & 0.84845966 & 0.026325 & 0.10195651 & 0.003117 & 0.933 & 626 & 18 & 624 & 14 & 615 & 24 & -1.8 \\
\hline 16.2 & 27708 & 0.02 & 0.06092 & 0.00070 & 0.85779807 & 0.02631 & 0.10199111 & \begin{tabular}{|l|}
0.003072 \\
\end{tabular} & 0.928 & 626 & 18 & 629 & 14 & 636 & 25 & 1.7 \\
\hline 17.2 & 29691 & 0.742 & 0.06006 & 0.00068 & 0.82856347 & 0.025684 & 0.09949568 & 0.003039 & 0.933 & 611 & 18 & 613 & 14 & 606 & 24 & -1.0 \\
\hline 20.1 & 18080 & 0.901 & 0.06057 & 0.00070 & 0.81568808 & 0.025057 & 0.09781799 & \begin{tabular}{|l|}
0.00295 \\
\end{tabular} & 0.928 & 602 & 17 & 606 & 14 & 624 & 25 & 3.8 \\
\hline 22.1 & 25221 & 0.379 & 0.06022 & 0.00070 & 0.81899225 & 0.025146 & 0.09840123 & 0.002964 & 0.927 & 605 & 17 & 607 & 14 & 612 & 25 & 1.1 \\
\hline 23.1 & 22786 & 0.247 & 0.06018 & 0.00071 & \begin{tabular}{|l|}
0.82403529 \\
\end{tabular} & 0.025362 & \begin{tabular}{|l|}
0.09875742 \\
\end{tabular} & 0.002976 & 0.925 & 607 & 17 & 610 & 14 & 610 & 25 & 0.5 \\
\hline 24.1 & 30352 & 0.024 & 0.06039 & 0.00070 & 0.8327225 & 0.025543 & 0.10003118 & 0.003014 & 0.928 & 615 & 18 & 615 & 14 & 617 & 25 & 0.5 \\
\hline 25.1 & 26344 & 0.653 & 0.06195 & 0.00072 & 0.91640487 & 0.028359 & 0.10702357 & 0.003248 & 0.927 & 655 & 19 & 660 & 15 & 673 & 25 & 2.7 \\
\hline 26.1 & 31092 & 0.043 & 0.06122 & 0.00071 & \begin{tabular}{|l|}
0.86337417 \\
\end{tabular} & 0.026911 & \begin{tabular}{|l|}
0.10247058 \\
\end{tabular} & 0.003134 & 0.929 & 629 & 18 & 632 & 15 & 647 & 25 & 2.9 \\
\hline
\end{tabular}


Tabela 9.5 - Resultados das análises Lu-Hf in situ nos zircões do leucossoma e paleossoma da Unidade Metatexítica.

\begin{tabular}{|c|c|c|c|c|c|c|c|c|c|c|}
\hline \multicolumn{11}{|c|}{ Unidade Metatexítica - Leucossoma (Gx-77A2) } \\
\hline & ${ }^{176} \mathrm{Hf} /{ }^{177} \mathrm{Hf}$ & $\pm 2 \sigma$ & ${ }^{176} \mathrm{Lu} /{ }^{177} \mathrm{Hf}$ & $\pm 2 \sigma$ & U-Pb Age (T1) & $\varepsilon \mathrm{Hf}(0)$ & ${ }^{176} \mathrm{Hf} /{ }^{177} \mathrm{Hf}(\mathrm{i})$ & $\varepsilon \mathrm{Hf}(\mathrm{T} 1)$ & $T_{\mathrm{DM}}$ & $\varepsilon \mathrm{Hf}(\mathrm{tdm})$ \\
\hline $1.1^{\mathrm{p}}$ & 0.281895 & 0.000024 & 0.000225 & 0.000001 & 593 & -31.0089 & 0.281893 & -18.05 & 2622 & 6.65 \\
\hline $9.1^{\mathrm{sb}}$ & 0.282007 & 0.000029 & 0.000528 & 0.000001 & 590 & -27.0441 & 0.282001 & -14.26 & 2384 & 7.53 \\
\hline $8.1^{\mathrm{p}}$ & 0.281626 & 0.000049 & 0.0011 & 0.000044 & 670 & -40.5182 & 0.281612 & -26.27 & 3191 & 4.55 \\
\hline $5.1^{\mathrm{sb}}$ & 0.281838 & 0.000038 & 0.000914 & 0.00002 & 611 & -33.0393 & 0.281827 & -19.97 & 2756 & 6.16 \\
\hline $7.1^{\mathrm{p}}$ & 0.281867 & 0.000027 & 0.0008 & 0.000011 & 592 & -32.0113 & 0.281858 & -19.3 & 2699 & 6.37 \\
\hline $20.1^{p}$ & 0.281841 & 0.000026 & 0.000431 & 0.000011 & 608 & -32.9282 & 0.281836 & -19.73 & 2738 & 6.23 \\
\hline $32.1^{\text {sb }}$ & 0.281792 & 0.00003 & 0.000856 & 0.000013 & 604 & -34.6419 & 0.281783 & -21.7 & 2858 & 5.79 \\
\hline $11.1^{p}$ & 0.281871 & 0.000027 & 0.000549 & 0.000016 & 597 & -31.8652 & 0.281865 & -18.95 & 2681 & 6.44 \\
\hline $31.1^{\mathrm{sb}}$ & 0.282024 & 0.000026 & 0.000456 & 0.000004 & 620 & -26.4576 & 0.282019 & -12.99 & 2328 & 7.74 \\
\hline $29.1^{\mathrm{sb}}$ & 0.281941 & 0.000029 & 0.000626 & 0.000002 & 613 & -29.3707 & 0.281934 & -16.13 & 2518 & 7.04 \\
\hline $19.1^{p}$ & 0.28204 & 0.000024 & 0.000187 & 0.000001 & 610 & -25.8864 & 0.282038 & -12.53 & 2291 & 7.87 \\
\hline $16.2^{p}$ & 0.282006 & 0.000022 & 0.000185 & 0.000003 & 613 & -27.0844 & 0.282004 & -13.66 & 2364 & 7.6 \\
\hline \multicolumn{11}{|c|}{ Unidade Metatexítica - Paleossoma (Gx-77B1) } \\
\hline & ${ }^{176} \mathrm{Hff}{ }^{177} \mathrm{Hf}$ & $\pm 2 \sigma$ & ${ }^{176} \mathrm{Lu} /{ }^{177} \mathrm{Hf}$ & $\pm 2 \sigma$ & U-Pb Age (T1) & $\varepsilon \mathrm{Hf}(0)$ & ${ }^{176} \mathrm{Hff}{ }^{177} \mathrm{Hf}(\mathrm{i})$ & $\varepsilon H f(T 1)$ & $\mathbf{T}_{\mathrm{DM}}$ & $\varepsilon \mathrm{Hf}(\mathrm{tdm})$ \\
\hline $4.1^{\mathrm{pn}}$ & 0.282070 & 0.000025 & 0.000275 & 0.000001 & 617 & -24.8378 & 0.282066 & -11.36 & 340524 & 8.12 \\
\hline $3.1^{\mathrm{pb}}$ & 0.282242 & 0.000024 & 0.000270 & 0.000004 & 626 & -18.7436 & 0.282239 & -5.06 & 1833 & 9.53 \\
\hline $2.1^{\mathrm{pn}}$ & 0.282106 & 0.000021 & 0.000298 & 0.000002 & 618 & -23.5519 & 0.282103 & -10.06 & 340591 & 8.41 \\
\hline $1.1^{\mathrm{pn}}$ & 0.282022 & 0.000025 & 1.460738 & 0.000046 & 612 & -26.5228 & 0.282012 & -13.53 & 2351 & 7.56 \\
\hline $8.1^{\mathrm{pb}}$ & 0.282177 & 0.000025 & 0.000324 & 0.000007 & 626 & -21.0408 & 0.282173 & -7.38 & 1980 & 9 \\
\hline $22.1^{\mathrm{pb}}$ & 0.282017 & 0.000037 & 0.000423 & 0.000006 & 606 & -26.7053 & 0.282012 & -13.53 & 2351 & 7.65 \\
\hline $23.1^{\mathrm{pn}}$ & 0.282179 & 0.000024 & 0.000231 & 0.000001 & 608 & -20.9719 & 0.282176 & -7.67 & 1984 & 8.99 \\
\hline $14.2^{\mathrm{pn}}$ & 0.282053 & 0.000024 & 1.460620 & 0.000070 & 634 & -24.4315 & 0.282076 & -10.65 & 2192 & 8.23 \\
\hline $10.1^{\mathrm{pb}}$ & 0.282144 & 0.000024 & 0.000194 & 0.000002 & 616 & -22.2091 & 0.282142 & -8.72 & 2056 & 8.72 \\
\hline $15.1^{\mathrm{pn}}$ & 0.282199 & 0.000024 & 0.000451 & 0.000001 & 619 & -20.2508 & 0.282194 & -6.80 & 1938 & 9.16 \\
\hline $16.1^{\mathrm{pn}}$ & 0.282129 & 0.000026 & 0.000438 & 0.000013 & 630 & -22.7419 & 0.282124 & -9.05 & 2088 & 8.61 \\
\hline $17.2^{\mathrm{pn}}$ & 0.281909 & 0.000024 & 0.000502 & 0.000006 & 615 & -30.5278 & 0.281903 & -17.20 & 2586 & 6.79 \\
\hline
\end{tabular}




\section{INTEGRAÇÃO DOS DADOS E DISCUSSÃO}

\subsection{Metamorfismo e microestruturas de fusão}

\section{Unidade Granulítica Basal}

Os granulitos bandados de composição básica apresentam $\mathrm{Hbl}+\mathrm{Cpx}+\mathrm{Opx}$ + PI como principal assembleia mineral e afinidades com a série toleiítica levemente enriquecida em magnésio (Figura 8.1 A, B e C). A geração de megacristais subidioblásticos de ortopiroxênio nas bandas granoblásticas pode ter seguido a reação $\mathrm{Hbl}+\mathrm{Qtz}=\mathrm{Opx}+\mathrm{Cpx} \pm \mathrm{Pl}+\mathrm{L}$, o que implica em temperaturas mínimas de $850^{\circ} \mathrm{C}$ para a fusão parcial, provavelmente, sob condições de desidratação da hornblenda (Figura 10).

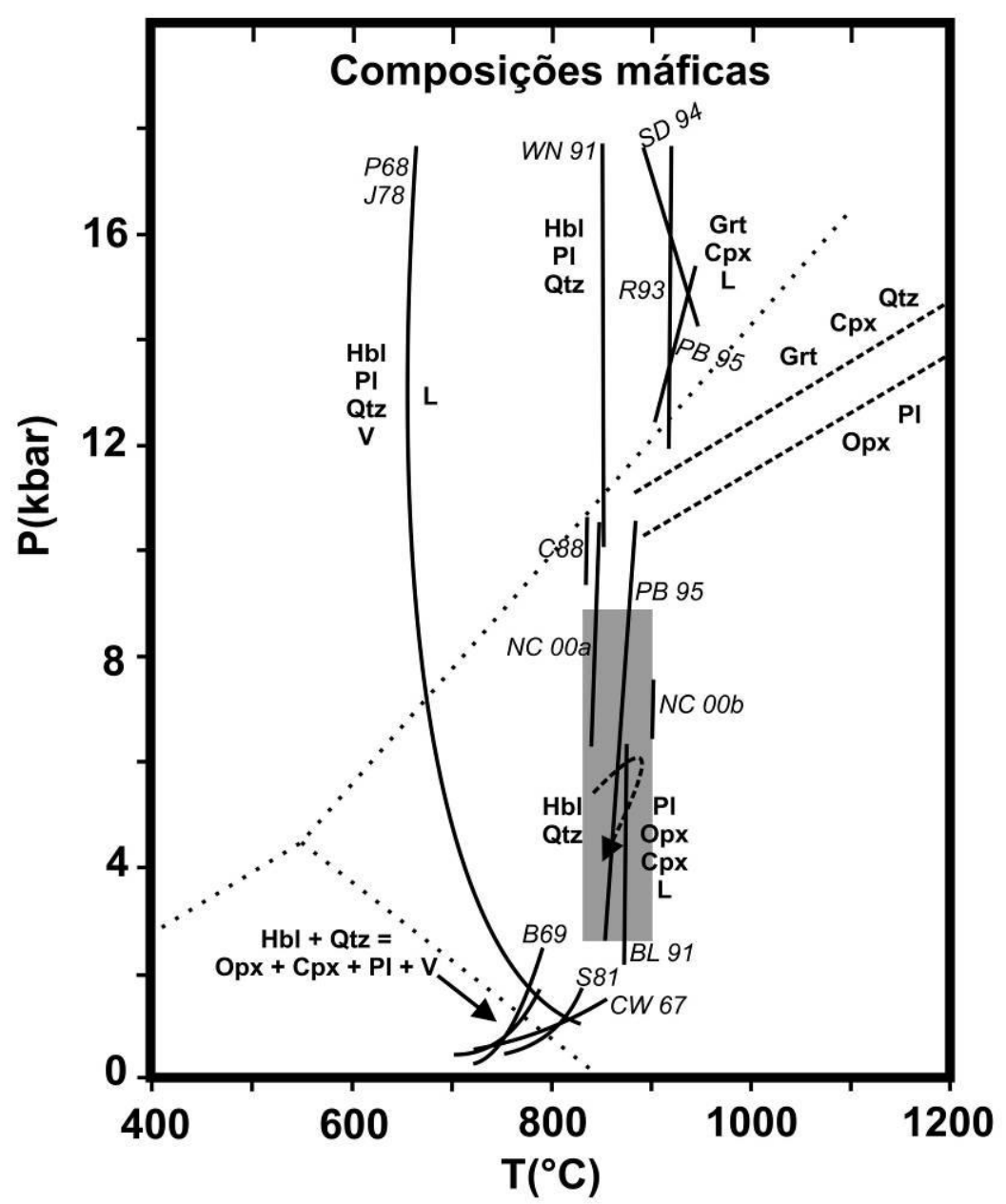

Figura 10 - Grade petrogenética com uma compilação de reações metamórficas determinadas a partir de cálculos termodinâmicos experimentais para rochas de composições máficas. O campo destacado em cinza refere-se à geração de leucossomas charnockíticos a charno-enderbíticos da Unidade Granulítica Basal, charnockitos da suíte SJRP e migmatito da Unidade Metatexítica. A flecha tracejada indica a possível trajetória metamórfica inferida. Extraído e adaptado de Pattison et al. (2003), onde constam as referências de cada reação. 
O leucossoma de composição charnockítica e afinidades cálcio-alcalinas de alto potássio pode ser resultado do processo de anatexia supracitado. Em algumas porções, o leucossoma ocorre paralelo ao bandamento dos granulitos, em parte, podendo representar as bandas granoblásticas com Opx desses granulitos. Em outros domínios, onde esse leucossoma é coletado, a textura passa de granoblástica para hipidiomórfica e são desenvolvidas feições de injeção triangulares em cúspide onde o leucossoma invade os granulitos bandados por meio de zonas dilatantes oblíquas ao bandamento (Figura 6.D).

De acordo com a Figura 8.2, onde temos um diagrama de elementos incompatíveis $\left(\mathrm{K}_{2} \mathrm{O}+\mathrm{Na}_{2} \mathrm{O}\right)$ por elementos compatíveis $(\mathrm{CaO}+\mathrm{MgO})$, os gnaisses ortoderivados com $\mathrm{Hbl}$ e $\mathrm{Cpx}$ (Gx-76C) apresentam um comportamento intermediário entre o leucossoma e o resíduo, provavelmente representando as rochas mais próximas de um paleossoma. As anomalias positivas de Eu, tanto no leucossoma charnockítico (Gx-76K) quanto nos granulitos de composição máfica (Figura 10.1), pode sugerir que ambos compõem um neossoma enriquecido em PI. Entretanto, as maiores razões $\mathrm{K} / \mathrm{Rb}$ e $\mathrm{Ba} / \mathrm{Sr}$ do leucossoma, mostram um caráter mais evoluído e enriquecido em feldspato alcalino do que o resíduo, onde essas razões são menores. As razões $\mathrm{K} / \mathrm{Rb}$ e $\mathrm{Ba} / \mathrm{Sr}$ do paleossoma são relativamente baixas porém intermediárias entre o leucossoma e o resíduo, reforçando a interpretação de uma composição próxima à do paleossoma. A leve anomalia positiva de Eu (1.04) dos gnaisses ortoderivados sugere que o PI do paleossoma não participou da reação de fusão, corroborando com a reação de mais baixa pressão proposta na Figura 10. Além disso, a baixa razão $\mathrm{Rb} / \mathrm{Sr}(<0.6)$ observada no leucossoma é compatível com leucossomas formados a partir da anatexia por desidratação da hornblenda de fontes metaígneas intermediárias de crosta continental inferior (Flierdt et al. 2003), como é o caso dos ortognaisses com $\mathrm{Hbl} \mathrm{e}$ Cpx.

Quando os elementos terras raras (ETR) são normalizados para o possível paleossoma ortognáissico, observa-se que o leucossoma é enriquecido em ETRleves e empobrecido em ETR-pesados. Por outro lado, o resíduo é empobrecido em ETR-leves e enriquecido nos ETR-pesados (Figura 10.1). Tal comportamento pode indicar a presença de Opx, Cpx, $\mathrm{Hbl}$ e Zrn no resíduo, uma vez que esses minerais tipicamente tendem a incorporar os ETR-pesados. Entretanto, os maiores valores de $\mathrm{Zr}$, Hf, Th e $\mathrm{U}$ no leucossoma mostram o fracionamento dessa fase acessória também para o leucossoma (Figura 10.1). 

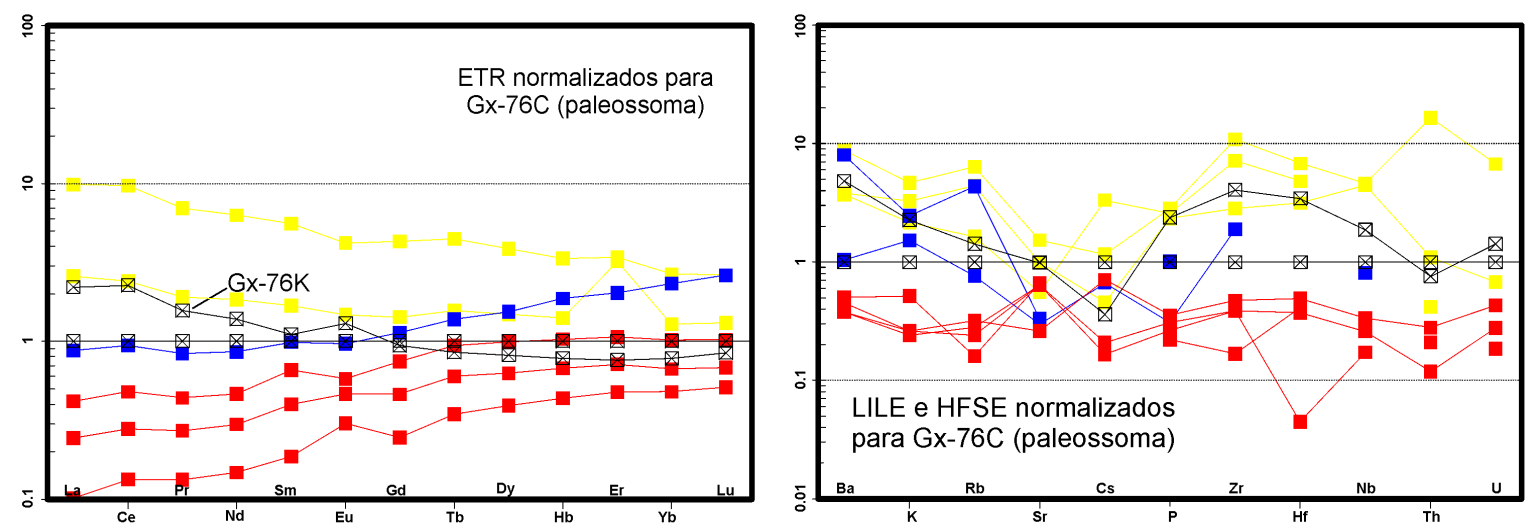

Figura 10.1 - Padrão de elementos terras raras (ETR) normalizados para o possível paleossoma (Gx-76C) dos leucossomas charnockíticos (Gx-76K); Padrão dos elementos LILE e HFSE normalizados para o mesmo paleossoma. Em vermelho, são representados granulitos básicos, em azul, granulitos ácidos e em amarelo, granulitos intermediários.

A presença, principalmente nas rochas granulíticas residuais, de pseudomorfos de fusão monocristalinos de plagioclásio, com ângulos dihedrais < $60^{\circ}$, indica que o líquido anatético gerado apresenta conectividade através da rocha (Holness \& Sawyer, 2008), desenvolvendo redes interligadas de fundido que podem ser extraídas ou não da fonte, dependendo, por exemplo, da taxa de fusão e do campo deformacional atuante. Esses pseudomorfos são boas evidências da segregação do líquido charnockítico, deixando para trás os granulitos máficos residuais. $\mathrm{O}$ bandamento composicional entre bandas tonalíticas com Opx e bandas ricas em hornblenda dos granulitos máficos residuais pode ser resultado desse processo de segregação, onde as bandas tonalíticas representam os principais caminhos de migração do leucossoma.

Os valores de $\varepsilon_{\mathrm{Nd}(640)}=-9.56$ e de ${ }^{87} \mathrm{Sr}^{86} \mathrm{Sr}_{\mathrm{i}(640)}=0.7074$ do leucossoma charnockítico (Gx-76K) assemelham-se aos membros mais enriquecidos dos ortognaisses $\left(\varepsilon_{\mathrm{Nd}(640)}=-10\right.$ e de $\left.{ }^{87} \mathrm{Sr}^{86} \mathrm{Sr}_{\mathrm{i}(640)}=0.712\right)$ e granulitos máficos (com até $\varepsilon_{\mathrm{Nd}(640)}=-10$ e de $\left.{ }^{87} \mathrm{Sr}^{86} \mathrm{Sr}_{\mathrm{i}(640)}=0.710\right)$, indicando uma anatexia a partir de um reservatório crustal já possivelmente retrabalhado (Figura $9.1 \mathrm{~B}$ ). Os valores de $\varepsilon_{\mathrm{Nd}(640)}=-3.21$ e de ${ }^{87} \mathrm{Sr}^{86} \mathrm{Sr}_{\mathrm{i}(640)}=0.705$ do ortognaisse $\mathrm{Gx}-76 \mathrm{C}$, por outro lado, indicam uma contribuição de um reservatório mais empobrecido, como a crosta continental inferior ou mesmo a litosfera subcontinental.

Dessa forma, o ortognaisse Gx-76C, além de apresentar as composições mais próximas do paleossoma para o leucossoma charnockíticos, pode ter guardado assinaturas magmáticas sin-orogênicas e pré-granulitização. Essa rocha possui características geralmente associadas ao magmatismo adakítico, como (verificar Condie, 2005 e Moyen, 2009 para cutoffs): Sr/Y = 72.73, La/Yb = 23.07, $(\mathrm{La} / \mathrm{Yb})_{\mathrm{N}}=$ 
15.56, $\# \mathrm{mg}=51.77, \mathrm{Sr}=1062 \mathrm{ppm}, \mathrm{Cr}=197 \mathrm{ppm}$ e $\mathrm{Ni}=103 \mathrm{ppm}$. Dessa forma, pode-se sugerir que as rochas ígneas ( $646 \mathrm{Ma}$ cf. Figura 9 ), que foram posteriormente submetidas ao metamorfismo no fácies granulito, resultaram de magmas adakíticos provenientes da fusão parcial do slab em subducção.

Após o pico térmico em torno de $850^{\circ} \mathrm{C}$, as rochas da Unidade Granulítica Basal também registram um evento retrometamórfico com reidratação, como evidenciado pelas bandas ricas em $\mathrm{Hbl}$ tabulares que iniciaram sua blastese retrógrada a partir do consumo do Opx. Intercrescimentos simplectíticos entre biotita e plagioclásio também podem indicar eventos de reidratação (e.g. Sawyer 2008), seja por um novo evento com adição de água ou por líquido anatético remanescente.

\section{Unidade Diatexítica: Suíte Granito-Migmatítica Pinhal}

O caráter diatexítico das rochas migmatíticas da suíte Granito-Migmatítica Pinhal implica em um processo de anatexia com alta taxa de fusão, de modo que as relações com os possíveis protólitos não é tão direta. Esses diatexitos apresentam uma grande dispersão no diagrama $\varepsilon_{\mathrm{Nd}(625)}$ vs. ${ }^{87} \mathrm{Sr}^{86} \mathrm{Sr}_{\mathrm{i}(625)}$, mostrando a contribuição de diferentes áreas-fonte (Figura 9.4.B).

Os diatexitos portadores de granada, como no caso dos tipos schliere e schollen, e os biotita diatexitos porfiroclásticos, portadores de monazita, associam-se aos granitos do subtipo 2 de Janasi (1999). A termometria de saturação de zircão para essas rochas, segundo o mesmo autor, é entre $750-780^{\circ} \mathrm{C}$, sugerindo reações de fusão que envolvem maior $\mathrm{a}\left(\mathrm{H}_{2} \mathrm{O}\right)$, seja proveniente de minerais hidratados como muscovita ou com influxo externo.

Por outro lado, o hornblenda-biotita sienogranito (Gx-76E), portador de allanita como fase acessória, é compatível com os granitos do subtipo 1, cuja termometria de saturação de zircão indica temperaturas de fusão de $850^{\circ} \mathrm{C}$. Ainda segundo Janasi (op. cit.), essas rochas podem ter sido originadas por reações de fusão por desidratação da biotita a partir de protólitos granulíticos. Entretanto, como pode ser observado na Figura 8.3, os baixos teores de $\mathrm{Rb}$ e $\mathrm{Ba}$ dos possíveis protólitos desses diatexitos indicam uma fonte pobre em biotita.

O metamorfismo de alta temperatura $\left(M_{1}\right)$, que gerou esses diatexitos em torno de $625 \mathrm{Ma}$, pode ser representado por pseudomorfos de fusão policristalinos (PI + Qtz \pm Mica) em forma de gotas e inclusos nos cristais de granada (cf. Prancha 
II.B). Estes são discutidos na literatura (e.g. Cesare et al. 2009; Gao et al. 2012) como evidências de fusão parcial, uma vez que representariam a composição do líquido anatético. O líquido anatético ficaria preservado em fases peritéticas que cresceram durante reações de fusão incongruentes.

O caráter levemente peraluminoso dos diatexitos portadores de granada (Figura 8.1.D) pode sugerir a atuação de fases aluminosas no processo de anatexia, sugestivamente, através de reações de fusão como Als $+\mathrm{Plg}+\mathrm{Qtz}=\mathrm{Kfs}+\mathrm{Grt}+\mathrm{L}$ (Le Breton \& Thompson, 1988). Segundo Janasi (1999), metagrauvacas e granadagranulitos podem servir de fonte para essas rochas.

Pseudomorfos de fusão de quartzo como topologia em filmes entre cristais de granada e plagioclásio (Prancha II.A) podem indicar um processo de cristalização dos diatexitos portadores de líquido anatético $(L)$, o qual pode reagir, durante a descompressão, com as fases peritéticas, como a granada, e gerar coronas de Qtz + $\mathrm{Plg}$ ao redor dos porfiroblastos de granada (Figura 6.1.B).

Texturas de fusão sensu strictu (i.e aquelas que indicariam o início da fusão parcial, e não a cristalização do líquido anatético - nesse caso, pseudomorfos de fusão) podem estar preservadas como microestruturas triangulares com terminações em cúspide nas junções tríplices das fases reagentes (cf. Prancha II.E e F). Os ângulos dihedrais $<60^{\circ}$ dessas microestruturas indicam a conectividade do líquido anatético através das bordas dos grãos, como é observado em cristais de quartzo completamente envoltos por fundido em continuidade óptica (Prancha II.D). Tal conectividade, e talvez alta taxa de fusão, podem ter gerado piscinas de fundido (melt pools) a partir da qual se formaram alguns cristais de quartzo (Prancha II.C). Esses cristais de quartzo formaram-se a partir da cristalização dessa piscina de fundido, gerando pseudomorfos de fusão policristalinos que já indicam a diminuição de temperatura pós-anatexia.

A Figura 8.2 mostra que alguns paleossomas associados aos diatexitos Pinhal apresentam composições no campo "possíveis paleossomas", no centro do diagrama, e semelhantes à amostra Gx-22C. Outras composições um pouco mais ricas em $(\mathrm{CaO}+\mathrm{MgO})$, entre 10 e $20 \mathrm{wt} \%$, podem representar fontes residuais. Entretanto, a linha de conexão L3, entre o paleossoma e o hbl-bt granitóide, levaria a composições de rochas residuais um pouco mais ricas em álcalis. Essa variação está de acordo com os dados isotópicos $\mathrm{Sm}-\mathrm{Nd}$ e $\mathrm{Rb}$-Sr que mostram contribuições de diferentes áreas-fontes para os diatexitos. A falta de rochas residuais com composições como aquelas indicadas pela L3 pode sugerir que o neossoma não 
sofreu segregação, tendo migrado juntos (leucossoma + resíduo) a partir do paleossoma. Dessa forma, é justificável encontrar diatexitos do tipo schliere e schollen.

Quando o comportamento dos ETR é normalizado para o paleossoma Gx22C (Figura 10.2), observa-se que os diatexitos Pinhal apresentam dois padrões. 0 primeiro, rico em ETR-leves, com certo empobrecimento de ETR-pesados e com anomalias negativas de $\mathrm{Eu}$, pode indicar as rochas mais evoluídas. Já o segundo padrão, com baixo fracionamento dos elementos terras raras, pode representar as poções residuais dos diatexitos schliere e schollen, que são ricos em biotita $( \pm$ granada), corroborando também, com maiores conteúdos de $\mathrm{Rb}$ e Ba que são incorporados pela biotita.

Dentre os elementos do tipo HFSE, observa-se que o conteúdo de $\mathrm{Zr}$ varia, mostrando leucossomas enriquecidos e empobrecidos nesse elemento em relação ao paleossoma. $\mathrm{O}$ Th e o $U$ podem indicar cristalização de monazita, e empobrecimento de $\mathrm{P}$ pode indicar consumo de apatita.
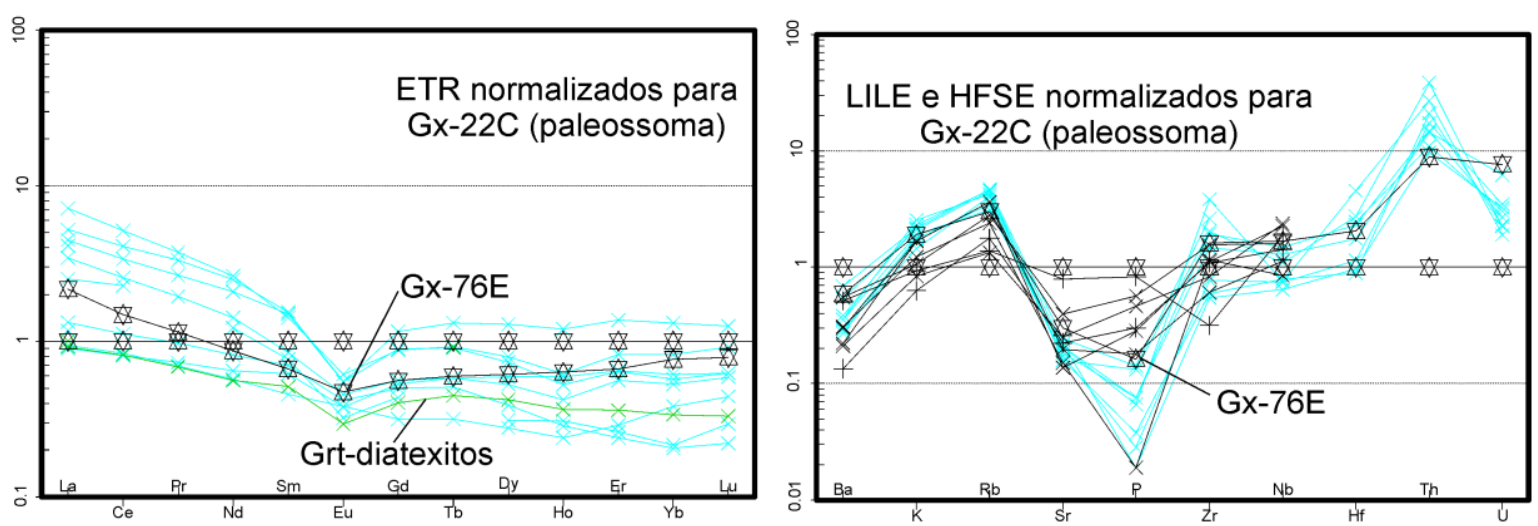

Figura 10.2 - Padrão de elementos terras raras (ETR) normalizados para o possível paleossoma (Gx22C) dos leucossomas granitos (Gx-76E); Padrão dos elementos LILE e HFSE normalizados para o mesmo paleossoma.

\section{Unidade Diatexítica: Suíte Granito-Charnockítica SJRP}

As temperaturas obtidas por termometria de saturação de apatita e zircão estão em torno de $950^{\circ} \mathrm{C}$ (Janasi 1999), sendo suficientes para desidratar biotita e hornblenda. As rochas charnockito-mangeríticas apresentam razões $\mathrm{Rb} / \mathrm{Sr}<0.5$, indicando fusão parcial por desidratação da hornblenda a partir de fontes metaígneas da crosta inferior.

O início da geração desses leucossomas charnockíticos e mangeríticos está ilustrado na Figura 6.4 A-D. Tanto o leucossoma Gx-78B quanto o paleossoma Gx- 
$78 \mathrm{~A}$, apresentam fracionamento de ETR semelhante às rochas charnockítomangeríticas de trabalhos anteriores (Figura 8.4). Em relação ao paleossoma, observa-se que o leucossoma é levemente mais enriquecido em ETR-leves e levemente mais empobrecido em ETR-pesados, sugerindo que o paleossoma é enriquecido em Opx, $\mathrm{Cpx}$ e $\mathrm{Hbl}$, ao passo que o leucossoma charno-mangerítico é um pouco mais evoluído e rico feldspatos. A forte anomalia positiva de Eu desses leucossoma indica um grande enriquecimento em plagioclásio, porém as razões $\mathrm{K} / \mathrm{Rb}$ e $\mathrm{Ba} / \mathrm{Sr}$ relativamente altas, indicam também a presença do feldspato alcalino. Já a anomalia levemente negativa do paleossoma pode indicar um certo empobrecimento em plagioclásio, sugerindo que talvez essa fase mineral tenha participado da reação de fusão. Entretanto, as baixas razões $\mathrm{K} / \mathrm{Rb}$ e $\mathrm{Ba} / \mathrm{Sr}$ indicam um certo enriquecimento em plagioclásio. Além disso, se o plagioclásio tivesse participado da reação de fusão, a granada seria um dos produtos (cf. Figura 10) nos leucossomas, o que não ocorre. Dessa forma, é possível inferir a mesma reação de fusão que atuou na Unidade Granulítica Basal: $\mathrm{Hbl}+\mathrm{Qtz}=\mathrm{Opx}+\mathrm{Cpx}+\mathrm{Pl}+\mathrm{L}$.

Diferentemente da Unidade Granulítica Basal, onde temos um neossoma segregado em leucossoma e resíduo fora da fonte, a relação de anatexia da suíte SJRP parece admitir um paleossoma rico em fases residuais, de modo que a única porção do neossoma que segregou e que saiu da fonte, foi o leucossoma.

Como mostrado na Figura 9.3.B, o comportamento isotópico da suíte SJRP apresenta dois grupos distintos, um mais empobrecido, com hornblenda granitóides e granulitos, e outro mais enriquecido com charnockitos e mangeritos. O paleossoma Gx-78A, com $\varepsilon_{\mathrm{Nd}(628)}=-10.1$ e ${ }^{87} \mathrm{Sr}^{86} \mathrm{Sr}_{\mathrm{i}(628)}=0.707$, apresenta afinidades com os granulitos mangeríticos empobrecidos e longa residência crustal $\left(\mathrm{T}_{\mathrm{DM}}=2.03 \mathrm{Ga}\right)$. O leucossoma Gx-78B, com $\varepsilon_{\mathrm{Nd}(628)}=-12.52 \mathrm{e}^{87} \mathrm{Sr}^{86} \mathrm{Sr}_{\mathrm{i}(628)}=0.708$, apresenta-se um pouco mais evoluído do que seu respectivo paleossoma, tendendo ao grupo de rochas mais enriquecidas. A cogeneticidade entre Gx-78A e Gx-78B é sugerida pelas idades $T_{D M}$ muito semelhantes.

Já o grupo de hornblenda granitóides, com $\varepsilon_{N d(628)}$ em torno de -5 e ${ }^{87} \mathrm{Sr}^{86} \mathrm{Sr}_{\mathrm{i}(628)}$ em torno de 0.707 , apresenta caráter fortemente empobrecido. Entretanto, alguns membros apresentam razões $\mathrm{Rb} / \mathrm{Sr}>1.0$, podendo indicar a desidratação da biotita a partir de fontes félsicas. $O$ alto fracionamento de ETR leves (Figura 8.3) pode indicar uma forte contribuição de allanita nas áreas fonte. Tanto o Bt-Cpx-Hbl ortognaisse da Unidade Granulítica Basal quanto os Hbl-Bt sienogranitos da suíte Pinhal, apresentam allanita como fase acessória. $O$ ortognaisse da Unidade 
Granulítica Basal, fortemente empobrecido, pode ser uma das fontes dos hornblenda granitóides em questão, os quais podem ter sofrido também algum tipo de interação de mistura com os granitos do tipo Pinhal. Além disso, a forte anomalia negativa de Eu dos hornblenda granitóides da SJRP, sugere uma cristalização a partir de líquidos anatéticos já pobres em plagioclásio, o qual está concentrado nos leucossomas charnockíticos e mangeríticos, mostrando que uma possível cristalização fracionada dos leucossomas charno-mangeríticos pode ter gerado os hornblenda granitóides, os quais, de fato, apresentam altas razões $\mathrm{K} / \mathrm{Rb}$ e $\mathrm{Ba} / \mathrm{Sr}$.

Assim como as rochas da suíte Pinhal, também é possível identificar uma fase de anatexia $\left(M_{1}\right)$ para os diatexitos da suíte SJRP, de ca. 625 - 628 Ma.

As rochas charnockíticas da suíte SJRP apresentam, basicamente, pseudomorfos de fusão (i.e. referem-se à cristalização de um a rocha contendo líquido anatético do $\mathrm{M} 1$ ) de plagioclásio com ângulos dihedrais $<60^{\circ}$ (Prancha Illa.B e III.F), o que implica, portanto, em uma boa conectividade do fundido através da rocha. Tal conectividade pode explicar a composição desses pseudomorfos de fusão, os quais apresentam-se como piscinas de fundido onde a fase principal é plagioclásio com alguns cristais de quartzo subeuhédricos crescendo a partir do líquido saturado em plagioclásio. Essa saturação, induzida pela conectividade do fundido, resulta da retirada das fases ricas em feldspato potássico, os quais podem ter servido como fonte para a geração dos hornblenda $( \pm \mathrm{Cpx} \pm \mathrm{Bt})$ granitóides. Alguns pseudomorfos de fusão de quartzo com bordas fortemente controladas pelas faces euhédricas de cristais de plagioclásio (Prancha III.a.A), podem significar fases finais da cristalização do leucossoma, portanto, não indicando de fato o começo do processo de fusão parcial.

De acordo com a Figura 8.1, as rochas da suíte SJRP são enriquecidas em potássio e apresentam afinidades shoshoníticas. Segundo Scarrow et al. (2009), as rochas que possuem essa afinidade devem também ser subdivididas de acordo com outros parâmetros, como o mg\#, as concentrações dos elementos do tipo LILE e HFSE e as razões entre ETR leves e ETR pesados. Com isso é possível identificar as rochas da suíte SJRP como vaugneritos, que são rochas de alto potássio enriquecidas em Mg, LILE, HFSE e ETR leves. Além disso, as assinaturas isotópicas de $\mathrm{Nd}$ e $\mathrm{Sr}$ caracterizam essas rochas como enriquecidas, cujos reservatórios podem ter composições similares ao manto litosférico ou à crosta.

Os vaugneritos apresentam uma composição consistente com uma derivação a partir de um manto litosférico metassomatizado. A fonte desse metassomatismo 
deve ser a desidrataçãoo de um slab em subducção, implicando em um processo orogênico controlado por subducção precedente à geração dessas rochas (Scarrow et al., 2009).

\section{Unidade Metatexítica: gnaisses migmatíticos}

Os gnaisses migmatíticos da Unidade Metatexítica apresentam, como paleossoma, Bt-Hbl gnaisses de composição granodiorítica a tonalítica, por vezes mangeríticos. Os leucossomas associados são Bt-Hbl granodioritos a Cpx charnoenderbitos que ocorrem em dobras recumbentes junto com o paleossoma. São encontrados também como injeções nos plano-axiais dessas dobras recumbentes.

Microestruturas de fusão parcial indicam que a $\mathrm{Hbl}$ é uma importante fase que foi fundida para gerar o leucossoma. Filmes de fundido (Prancha IV.A) ocorrem entre $\mathrm{Hbl}$, Pl e Qtz, podendo sugerir uma reação de fusão envolvendo essas três fases. Entretanto, o contato retilíneo entre o plagioclásio e o fundido e o contato lobado a levemente corroído entre o fundido e a hornblenda, sugere que o plagioclásio se manteve como uma fase estável durante a fusão, corroborando para a mesma reação de fusão observada para as rochas da Unidade Granulítica Basal e rochas charnockíticas da suíte SJRP: $\mathrm{Hbl}+\mathrm{Qtz}=\mathrm{Cpx}+\mathrm{Opx}+\mathrm{PI}+\mathrm{L}$ (Figura 10). A anomalia levemente negativa do paleossoma Gx-77B1 (Figura 8.4) sugere que ele não contribuiu, ou contribuiu muito pouco, com plagioclásio para a geração dos leucossomas. A razão $\mathrm{Rb} / \mathrm{Sr} \sim 0.14$, muito baixa do leucossoma, indica uma anatexia por desidratação da hornblenda a partir de fonte metaígneas (Flierdt et al., 2003).

O resultado direto da reação de fusão é a geração de leucossomas charnoenderbíticos, com possível cristalização fracionada para a geração dos leucossomas granodioríticos. De fato, o leucossoma granodiorítico Gx-77A2 apresenta forte anomalia negativa de Eu, indicando que sua cristalização foi a partir de líquidos que já tinham cristalizado quase todo o plagioclásio, como é o caso dos charnoenderbitos.

A Figura 8.2 mostra, em relação aos elementos maiores incompatíveis e compatíveis, que o paleossoma está no campo dos "possíveis paleossomas" e que seu leucossoma associado tende ao campo das rochas diatexíticas. 0 fracionamento dos ETR-pesados indica que o paleossoma é empobrecido em fases residuais em relação ao leucossoma, o que pode indicar uma possível segregação entre leucossoma e resíduo (este, entretanto, não amostrado). As idades modelos 
$T_{D M(N d)}$ entre as amostras Gx-77A2 e Gx-77B1 são muito próximas, respectivamente, 2.08 e $2.02 \mathrm{Ga}$, podendo indicar que elas são cogenéticas e que o $\mathrm{Bt}-\mathrm{Hbl}$ gnaisse (Gx-77B1) apresenta-se com composições mais próximas àquelas do paleossoma.

Após o metamorfismo de alta temperatura com anatexia sob condições de desidratação da hornblenda até $608 \mathrm{Ma}$, pseudomorfos de fusão (Prancha IV.F) indicam a cristalização do leucossoma portador de líquido anatético. Além disso, tanto o paleossoma quanto o leucossoma sofreram um processo de rehidratação, com a geração de cristais grandes de hornblenda com inclusões de piroxênio, e a substituição, tanto de Opx quanto de Cpx, por hornblenda (Prancha IV.C e E).

\subsection{Idade do metamorfismo}

No lobo Guaxupé, a maior parte dos dados geocronológicos da literatura foi obtida a partir das rochas da Unidade Granulítica Basal e da Unidade Diatexítica. Neste trabalho, novos dados geocronológicos foram obtidos nos gnaisses migmatíticos da Unidade Metatexítica. Essa unidade apresenta condições metamórficas de alta temperatura com fusão parcial. A geração de leucossomas graníticos contendo fases peritéticas anidras, como o Opx, evidencia um processo de fusão parcial sem a presença de água livre. As condições térmicas para a geração desses leucossomas estão acima dos $850^{\circ} \mathrm{C}$ - em fácies granulito-, uma vez que foi inferida a fusão de um protólito intermediário, a partir da desidratação da hornblenda, por meio de reações de fusão incongruentes. Sob essas condições térmicas, grande parte dos minerais radiométricos usados em geocronologia já teve seu sistema reaberto, com exceção do zircão, o qual mantém grande parte de sua memória isotópica. Nem todos os cristais de zircão contidos em rochas do fácies granulito refletem idades do pico metamórfico, com exceção daqueles contidos em leucossomas associados à fusão parcial (Roberts \& Finger 1997).

O leucossoma $G x-77 A 2$, enriquecido em $Z r$ em relação ao seu paleossoma Gx-77B1, apresenta duas morfologias principais de zircão. A primeira apresenta cristais prismáticos e bipiramidados com idade de $621 \pm 16 \mathrm{Ma}$, e a segunda apresenta cristais isométricos (esféricos e multifacetados) do tipo soccer-ball com idade de $608 \pm 4$ Ma. Na literatura (e.g. Vavra et al. 1999; Hokada \& Harley 2004; Tichomirowa et al. 2005), os zircões do tipo soccer ball são descritos em rochas de alta temperatura e pressão, como granulitos e eclogitos. 
No caso dos leucossomas da Unidade Metatexítica, a morfologia esférica dos zircões, provavelmente, não se deve a grandes gradientes báricos, já que, segundo os dados regionais, essa unidade apresenta os valores mais baixos de pressão quando comparados às outras unidades. Uma possível alternativa seria a reabsorção das porções marginais do zircão devido à interação com líquido anatético (Tichomirowa et al. op. cit.). O fundido gerado a partir de reações de fusão incongruentes é enriquecido em $\mathrm{SiO}_{2}$ e apresenta baixa solubilidade do zircão (Watson \& Harrison 1983), de modo que o zircão não é totalmente consumido pelo fundido. A interação com líquido anatético pode gerar então uma reabsorção marginal dos cristais, tornando-os esféricos a partir de hábitos facetados.

Dessa forma, é possível inferir que o processo de fusão parcial teve início, no mínimo, em $\sim 621 \mathrm{Ma}$, quando da formação dos primeiros cristais de zircão prismáticos. As idades mais jovens, dos cristais de zircão esféricos, podem indicar a idade máxima da interação zircão/fundido. A partir desse momento, com a diminuição da temperatura e com a saturação do fundido em Si e Al, a solubilidade do zircão diminui bastante (Roberts \& Finger 1997), tornando-o uma fase estável com sistema isotópico fechado. A idade de interação zircão/fundido, de $608 \mathrm{Ma}$, pode indicar a idade máxima de um período caracterizado por altas temperaturas, uma vez que o zircão estaria sendo reabsorvido a partir de um líquido anatético em alta temperatura. Após a estabilização do zircão, é possível considerar que o leucossoma já estava em resfriamento.

Idades em torno de $625 \mathrm{Ma}$ são admitidas como as melhores aproximações para o pico metamórfico da NSG (e.g. Janasi, 1999; Campos Neto et al. 2004). Entretanto, os zircões do tipo soccer ball da Unidade Metatexítica, na porção sulocidental do lobo Guaxupé, apontam uma idade de $608 \mathrm{Ma}$ ainda sob altas condições térmicas. Uma vez admitido que a morfologia dos zircões esféricos de alta temperatura se desenvolveu devido à interação zircão/fundido, assume-se que as condições de alta temperatura, iniciadas por volta de $625 \mathrm{Ma}$, podem ter se mantido até a estabilização dos zircões esféricos. Portanto, a idade de 608 Ma não deve refletir um novo evento anatético, e sim limita um período de $\sim 17$ my em que predominou um metamorfismo de alta temperatura.

As idades registradas nos cristais de zircão do paleossoma indicam dois picos, um em $614 \mathrm{Ma}$, podendo refletir a idade mais jovem do pico térmico, e outro em $640 \mathrm{Ma}$, remetendo ao magmatismo sin-orogênico que, depois, deu origem aos ortognaisses. 


\subsection{Transporte tectônico e deformação: W-SW do lobo Guaxupé}

Na porção W-SW do lobo Guaxupé, compreendendo as Unidades Diatexítica e Metatexítica, o transporte tectônico sin-metamórfico de alta temperatura ocorre em regime de compressão e está associado ao avanço da NSG para NE. Na área de estudo, a variação dos rumos de transporte sin-magmático é devido à falha de cavalgamento que coloca a Unidade Diatexítica sobre a Metatexítica (mapa, Anexo I). Perto da cidade de São Sebastião da Grama, a movimentação ocorre para NE em componente inversa e de forma puramente sin-magmática. Já nos arredores da cidade de São José do Rio Pardo, esse transporte passa a ter um rumo para E em componente direcional e um comportamento transicional entre o sin-magmático e 0 estado sólido, como evidenciado pela convivência entre fenocristais e porfiroclastos. Esse transporte para E-ESE também é observado nas rochas diatexíticas mais a $E$, na altura da cidade de Caconde.

O transporte segundo a direção E-W pode indicar o final do evento sinmagmático de fluxo dos diatexitos, onde o magma começa a cristalizar e torna-se uma barreira para os fenocristais que, por sua vez, começam a recristalizar nas bordas. Texturas do tipo string of beads em pseudomorfos de fusão com topologia em filmes podem evidenciar o reequilíbrio estático após a cristalização dos diatextios. Esse reequilíbrio, em fácies anfibolito, também é evidenciado por cristais menores de plagioclásio e quartzo que desenvolveram bordas retilíneas e poligonizadas entre si. A orientação do fluxo está associada às altas temperaturas estimadas para a geração dessas rochas em fácies granulito (acima de $850^{\circ} \mathrm{C}$ para a suíte Pinhal e acima de $950^{\circ} \mathrm{C}$ para a suíte SJRP, segundo Janasi, 1999), com idade aproximada de $625 \mathrm{Ma}$.

Entretanto, a presença de contatos interlobados entre cristais de quartzo, a extinção ondulante em cristais poligonizados e a extinção ondulante nos pseudomorfos de fusão, indicam um evento deformacional posterior à cristalização dos diatexitos. Tal evento, provavelmente está associado ao transporte tectônico para NW, em estado sólido e alta temperatura, marcado pela recristalização manteada de feldspato potássico e por lineações de estiramento de hornblenda. $O$ cisalhamento deve ter ocorrido a temperaturas acima de $700^{\circ} \mathrm{C}$, quando é possível desenvolver deformação intracristalina na hornblenda (Kruse \& Stunitz, 1999) e gerar porfiroclastos do tipo fish e pinch-and-swell. Na Unidade Metatexítica, o 
transporte para NW está associado à temperaturas $\geq 850^{\circ} \mathrm{C}$, as quais, como discutido anteriormente, podem ter se mantido altas até 608 Ma.

O transporte para S, na Unidade Diatexítica, está associado ao desenvolvimento de faixas ultramiloníticas, levemente oblíquas à foliação dos diatexitos, com componente normal e arranjos S/C' em estado sólido. O fato de este transporte estar associado a porfiroclastos de feldspato e a cristais de hornblenda não deformados, indica um processo a temperaturas mais baixas do que $\sim 700^{\circ} \mathrm{C}$, colocando-o como posterior aos eventos para NE e NW. Podem indicar o momento de relaxamento ou colapso gravitacional da Nappe Socorro-Guaxupé.

Nas porções basais do lobo Guaxupé, entre as cidades de Tipiratiba e Guaxupé, o transporte tectônico descrito nesse trabalho é para SE. Esse comportamento pode estar associado ao transporte para SE da unidade Diatexítica ou pode se relacionar ao comportamento sinistral da zona de cisalhamento Campo do Meio (Morales et al., 2005). Segundo os mesmos autores, na porção NW do lobo Guaxupé, desde Muzambinho até Guaxupé, há uma grande predominância de indicadores cinemáticos com topo para NW.

\subsection{Considerações finais e implicações tectônicas}

Na porção sul-ocidental do lobo Guaxupé, as rochas granulíticas e gnáissicas que constroem a base da Nappe Socorro-Guaxupé guardam assinaturas isotópicas que remetem a fontes empobrecidas e idades que remontam há 640 Ma. Idades entre 660-640 Ma (e.g. Hachspacker et al., 2003) refletem o magmatismo cálcioalcalino sin-orogênico durante a subducção da crosta oceânica associada à placa Sanfranciscana. Os gnaisses com características adakíticas (cf. ítem 10.1) apresentam uma boa evidência para um estágio de orogenia controlada por subducção, uma vez que essas rochas são geralmente associadas à fusão do slab descendente.

As assinaturas isotópicas mais enriquecidas das rochas diatexíticas de alto potássio, como a afinidade vaugnerítica da suíte SJRP (cf. ítem 10.1) , sugerem como fonte uma crosta continental retrabalhada ou metassomatizada devido a processos de subducção precedentes. A geração das suítes diatexíticas está associada ao metamorfismo de alta temperatura há cerca de $625 \mathrm{Ma}$ com um fluxo em estado sub-sólido orientado para NE-E. A presença de pseudomorfos de fusão indica que essas rochas tiveram uma evolução quase isotérmica na presença de líquido anatético. 
Janasi et al. (2009) sugerem uma contribuição de magmas mantélicos devido à quebra do slab em subducção (slab breakoff) para explicar o alto fluxo térmico responsável por um pico metamórfico no fácies granulito. Alternativamente, a delaminação de parte da litosfera na raiz do arco teria facilitado a ascenção da astenosfera e o incremento da velocidade da placa superior contra a inferior (e.g. Pope \& Willett, 1998; Shurr et al., 2006), gerando o fluxo sin-magmático para E-NE.

O transporte tectônico para NW posterior, em estado sólido e alta temperatura, pode estar associado à compressão da placa superior devido à horizontalização do slab. Esse regime tectônico, em parte semelhante ao estágio orogênico que, a partir do Mioceno nos Andes Centrais, foi denominado de Pampean flat slab (Gutcher et al., 2000a; Ramos et al, 2002; Orts et al, 2012) pode ter sido responsável pelo transporte para NW da raiz do arco em direção ao interior da placa superior.

O metamorfismo de alta temperatura, iniciado $\sim 625 \mathrm{Ma}$, perdurou até a idade, na margem de erro $(608 \pm 4 \mathrm{Ma})$, dos maciços sieníticos pós-deformacionais Capituva e Pedra Branca, há cerca de 610 Ma. Janasi (1992) estimou um nível de colocação raso (cerca de 10,5 km) para esses sienitos, baseado em uma pressão de $3 \mathrm{Kbar}$. Como as condições báricas das rochas de alta temperatura na região foram estimadas em cerca de 6,0 \pm 2 kbar (correspondente a cerca de $27 \mathrm{~km}$ de profundidade) para temperaturas entre $850-900^{\circ} \mathrm{C}$ (Campos Neto et al, 2004), o desnível de aproximadamente $17 \mathrm{~km}$ na crosta corresponde à componente vertical do transporte de baixo ângulo durante 15 my. Considerando-se que o padrão essencialmente cilíndrico das dobras da foliação, com orientação axial de fraco caimento (Campos Neto \& Figueiredo, 1985), é indicativo de uma disposição subhorizontal da foliação metamórfica, a quantidade mínima de transporte do material rochoso em estado sub-sólido a sólido, de alta temperatura, deve ter excedido 150 $\mathrm{km}$.

A idade dos maciços sieníticos corresponde à idade de estabilização da NSG. Janasi (1993) afirma que a fonte dessas rochas está associada à fusão parcial da litosfera subcontinental ou a pulsos episódicos de magmas astenosféricos. Considerando um quadro tectônico de flat subduction, é possível sugerir que a placa sanfranciscana colidente não estava em subducção sob o arco quando da formação desses maciços. Caso estivesse, a crosta sob o arco estaria duplicada, de forma que a fonte de calor astenosférica estaria muito profunda em relação à base do arco. Posto isso, é possível que a litosfera oceânica, em subducção horizontal, estivesse 
sob o domínio de arco. Analogamente ao ciclo orogênico Andino (Ramos, 2009), a subducção horizontal pode se tornar, novamente, inclinada. Com isso, pode ser gerado um regime extensional. Por um lado, a quilha cratônica em colisão impede o avanço da subducção, e por outro, a nova inclinação da litosfera oceânica continua a movimentar a placa inferior por slab-pull. Nesse momento, é possível que haja o rompimento/fraturamento da litosfera oceânica, permitindo então a ascenção de magmas astenosféricos para a geração dos maciços sieníticos. 


\section{CONCLUSÕES}

A Nappe Socorro-Guaxupé representa o domínio de arco magmático do Orógeno Brasília Meridional que resultou da convergência entre a Placa Paranapanema e a Sanfranciscana. Na porção norte da NSG, no lobo Guaxupé, a geração de grandes suítes diatexíticas e rochas metatexíticas são o resultado de um evento metamórfico de alta temperatura no fácies granulito cujo pico térmico ocorreu há $625 \mathrm{Ma}$.

A geração de leucossomas charno-endebíticos nas Unidades Granulítica Basal e Metatexítica e mangerito-graníticos na Unidade Diatexítica (suíte SJRP) seguiram reações de fusão por desidratação da hornblenda que implicam temperaturas mínimas de $850^{\circ} \mathrm{C}$. O comportamento dos elementos maiores e terras raras e assinaturas isotópicas $\left({ }^{87} \mathrm{Sr} /{ }^{86} \mathrm{Sr}\right.$, $\varepsilon \mathrm{Nd}$ e $\left.\varepsilon \mathrm{Hf}\right)$ sugerem protólitos que devem formar os níveis inferiores da crosta continental. Os diatexitos da suíte Pinhal possuem fontes mais diversas, como possíveis fontes metassedimentares para a geração de rochas peraluminosas contendo granada. Essas rochas sugerem temperaturas mais baixas, ao redor de $750^{\circ} \mathrm{C}$, e as assinaturas isotópicas indicam uma forte contribuição de crosta continental mais enriquecida e/ou retrabalhada.

O estudo pontual de cristais de zircão dos leucossomas da Unidade Metatexítica mostram que tais leucossomas se formaram entre 620 e 610 Ma. As idades mais jovens são de cristais isométricos geralmente atribuídos ao fácies granulito de alta temperatura, indicando que o metamorfismo de alta temperatura associado ao pico térmico, por volta de $625 \mathrm{Ma}$, se manteve por cerca de $15 \mathrm{my}$. As razões Th/U e o parâmetro petrogenético $\varepsilon \mathrm{Hf}$ indicam que os zircões isométricos e os zircões prismáticos derivaram a partir da crosta continental mais enriquecida e/ou retrabalhada. Alguns núcleos herdados (com idade pontual de $670 \mathrm{Ma}$ ) possuem assinaturas bem mais empobrecidas e idades modelo de $\mathrm{Hf}$ de $3.19 \mathrm{Ga}$, sugestivamente quando da formação dos protólitos metaígenos que compõem o embasamento do arco magmático.

Os cristais de zircão que possuem núcleos mais antigos entre 670 - $640 \mathrm{Ma}$, remontam à atividade magmática durante a orogênese controlada por subducção. $\mathrm{Na}$ Unidade Granulítica Basal, rochas ortognáissicas com idades semelhantes apresentam características adakíticas, sugerindo uma fonte a partir da fusão do slab em subducção. 
A orientação das lineações minerais, sua associação com indicadores cinemáticos e relações microtectônicas permitiram hierarquizar, no lobo Guaxupé, um transporte em estado sub-sólido a sub-sólido - sólido com cinemática compressiva para NE, um transporte, em estado sólido, para NW e por último, em regime extensional de mais baixa temperatura, para $\mathrm{S}$.

O fluxo da raiz do arco acompanha o transporte geral da NSG e é contemporâneo ao metamorfismo de alta temperatura iniciado há ca. $625 \mathrm{Ma}$ e que deve ter se estendido até ca. $610 \mathrm{Ma}$. Durante esse período de $15 \mathrm{my}$, o fluxo sinmagmático para NE associa-se ao pico térmico há 625 Ma, quando da geração das grandes suítes diatexíticas de alto potássio. Segue-se um transporte tectônico em estado sólido para NW resultante de um regime tectônico onde a subducção ocorreu de forma horizontal. O magmatismo pós-colisional no lobo Guaxupé é principalmente registrados pelos maciços sieníticos Pedra Branca e Capituva com cerca de $610 \mathrm{Ma}$, o qual marca o fim do período de migração do arco por cerca de $150 \mathrm{~km}$.

A fonte de calor para o metamorfismo de $625 \mathrm{Ma}$, em trabalhos anteriores, foi atribuída à quebra do slab em subducção e consequente underplating de rochas básicas na base da crosta continental. Alternativamente, a delaminação da litosfera na base do arco pode ter facilitado a ascenção astenosférica e consequente fusão parcial. A fonte de calor para a geração dos maciços sieníticos pode estar relacionada ao rompimento/fraturamento da litosfera oceânica em flat subduction devido à retomada de uma subducção inclinada, como ocorre no ciclo orogênico Andino.

Em suma, a evolução na Nappe Socorro-Guaxupé admite uma orogênese do tipo andina controlada por uma subducção inclinada entre 670 - $640 \mathrm{Ma}$ com a geração de rochas cálcio-alcalinas com alguma afinidade adakítica. Entre 625 - 610 Ma, é sugerido um período caracterizado por alta temperatura que se inicia com a geração de rochas diatexíticas sin-tectônicas de alto potássio transportadas para $\mathrm{NE}$, em direção ao cráton. Um transporte para NW, em direção ao interior da placa superior, deve resultar da horizontalização do slab em subducção. A estabilização da Nappe Socorro-Guaxupé deve ter ocorrido durante a geração dos maciços póscolisionais sieníticos.

A evolução da NSG, desde o magmatismo cálcio-alcalino, passando por uma subducção horizontal e com a posterior retomada de uma subducção inclinada descrevem características de um ciclo orogênico do tipo Andino. 


\section{REFERÊNCIAS BIBLIOGRÁFICAS}

Altenberger, U. \& Wilhelm, S., 2000. Ductile deformation of K-feldspar in dry eclogite facies shear zones in Bergen Arcs, Norway. Tectonophysics, 320: 107-212.

Basei, M.A.S.; Siga Jr, O.; Sato, K.; Sproesser, W.M., 1995. A metolodogia urâniochumbo na Universidade de São Paulo: princípios metodológicos, aplicações e resultados obtidos. Anais da Academia Brasileira de Ciências, 67(2): 221-237.

Baynton, W.V., 1984. Cosmochemistry of the rare earth elements. Meteorite studies Dev. Geochemistry, 2: 63-114.

Beaumont, C.; Jamieson, R.A.; Nguyen, M.H.; Medvedev, S., 2004. Crustal channel flows: Numerical models with applications to the tectonics of the HimalayanTibetan orogen. Journal of Geophysical Research, $109 . \quad$ Doi: 10.1029/2003JB002809.

Belousova, E.A.; Griffin, W.L.; O’Reilly, S.Y., 2006. Zircon crystal morphology, trace elements signatures and $\mathrm{Hf}$ isotope composition as a tool for petrogenetic modeling: examples from eastern Australian granitoids. Journal of Petrology, 47(2): 329-353.

Bowen, N.L., 1928. The evolution of Igneous Rocks. New Jersey: Princeton University Press.

Braga, I. F., 2002. Análise deformacional de rochas infracrustais da região de Cristina e Itajubá MG. Rio Claro, 197 p. Tese (Doutorado) - Instituto de Geociências e Ciências Exatas, Universidade Estadual Paulista.

Brito Neves, B.B.; Campos Neto, M.C.; Fuck, R.A., 1999. From Rodinia to Western Gondwana: an approach to the Brasiliano-Pan African Cycle and orogenic collage. Episodes, 22: 155-166.

Brown, M., 2001. Orogeny, migmatites and leucogranites: A review. Earth Planet. Sci., 110: 313-336.

Brown, M., 2007. Crustal melting and melt extraction, ascent and emplacement in orogens: mechanisms and consequences. Journal of the Geological Society, 164: 709-730.

Campos Neto, M.C.; Basei, M.A.S.; Arthur, A.C.; Silva, M.E.; Machado, R.; Dias Neto, C.M.; Fragoso Cesar, A.R., 1983. Geologia das Folhas Piracaia e Igaratá. 
In: $1^{\text {a }}$ Jornada sobre a Carta Geológica do Estado de São Paulo em 1:50.000. Pró-Minério, São Paulo, p. 61-78.

Campos Neto, M.C. \& Figueiredo, M.C.H., 1985. Geologia das Folhas São José do Rio Pardo e Guaranésia (porção paulista), 1:50.000. IGc-USP e SICCT-PDRM $S P, 115 \mathrm{pp}$.

Campos Neto, M.C.; Figueiredo, M.C.H.; Janasi, V.A.; Basei, M.A.S.; Fryer, B.J. 1988. The São José do Rio Pardo Mangeritic Suite. Geochemica Brasiliensis, 2 : 185-199.

Campos Neto, M.C. \& Figueiredo, M.C.H. 1995. The Rio Doce Orogeny, Southeastern Brazil. Journal of South American Earth Sciences, 8: 143-162.

Campos Neto, M.C., 2000. Orogenic System from Southwestern Gondwana: An approach to Brasiliano-Pan African cycle and orogenic collage in Southeastern Brazil. In: Cordani, U.G., Milani, E.J., Thomaz Filho, A. e Campos, D.A. TECTONIC EVOLUTION OF SOUTH AMERICA, $31^{\text {ST }}$ International Geological Congress: 335-365.

Campos Neto, M. C. \& Caby, R. 2000. Terrane accretion and upward extrusion of high-pressure granulites in the Neoproterozoic nappes of southeast Brazil: petrologic and structural constraints. Tectonics, 19 (4): 669-687.

Campos Neto, M. C.; Basei, M. A. S.; Vlach, S. R. F.; Caby, R.; Szabó, G. A. J.; Vasconcelos, P. 2004. Migração de orógenos e superposição de orogêneses: um esboço da colagem brasiliana no sul do Cráton do São Francisco, SE Brasil. Revista do Instituto de Geociências - USP. São Paulo, 4 (1): 13-40.

Campos Neto, M.C.; Ciofii, C.R.; Moraes, R.; Motta, R.G.; Siga Jr, O.; Basei, M.A.S., 2010. Structural and metamorphic control on the exhumation of high-P granulites: Carvalhos Klippe example, from the oriental Andrelândia Nappe System, southern portion of the Brasília Orogen, Brazil. Precambrian Research 180: 125-142.

Campos Neto, M.C.; Basei, M.A.S.; Janasi, V.A; Moraes, R., 2011. Orogen migration and tectonic setting of the Andrelândia Nappe System: An Ediacaran Western Gondwana Collage, South of São Francisco Craton. Journal of South American Earth Sciences, 32: 393-406.

Carson, C.J.; Ague, J.J.; Coath, C.D., 2002. U-Pb geochronology from Tonagh Isleand, East Antarctica: implications for the timing of ultha-high temperature metamorphism in the Napier Complex. Precambrian Research, 116: 237-263. 
Cesare, B.; Ferrero, S.; Salvioli-Mariani, E.; Pedron, D.; Cavallo, A., 2009. "Nanogranite" and glassy inclusions: The anatectic melt in migmatites and granulites. Geology 37: 627-630.

Condie, K.C., 2005. TTGs and adakites: are they both slab melts? Lithos, 80: 33-44.

Cook, F.A. \& Varsek, J.L., 1994. Orogen-scale decollements. Reviews of Geophysics, 32, 37-60.

Clemens, J.D., 2005. Granites and granitic magmas: strange phenomena and new perspectives on old problems. Proceedings of the Geologists'Association, 116: 916.

Clemens, J.D. \& Watkins, J.M., 2001. The fluid regime of high-temperature metamorphism during granitoid magma genesis. Contributions to Mineralogy and Petrology, 140: 600-606.

De Paolo, D.J., 1981. Trace element and isotopic effects of combined wallrock assimilation and fractional crystallization. Earth Planet. Sci. Lett., 53: 189-202.

Ebert, H., 1984. Os Paraibides entre São João Del Rei, MG e Itapira, SP, e a bifurcação entre Paraibides e Araxaídes (in memoriam). São Paulo, SBG-SP, Publ. Esp., 12/84: 72-103.

Ebert, H.; Chamele Jr, F.; Babinski, M.; Artur, A.C.; van Schmus, W.R., 1996. Tectonic setting and $\mathrm{U} / \mathrm{Pb}$ zircon dating of the plutonic Socorro Complex in the transpressive Rio Paraiba do Sul Shear Belt, SE Brazil. Tectonics, 15: 688-699.

Flierdt, T. Van de.; Hoerness, S.; Jung, S.; Masberg, P.; Hoffer, E.; Schaltegger, U.; Friedrichsen, H., 2003. Lower crustal melting and the role of open-system in the genesis of syn-orogenic quartz diorite-granite-leucogranite associations: constraints from Sm-Nd-O isotopes from the Bandoombai Complex, Namibia. Lithos, 67: 205-226.

Gao, X.-Y.; ZHENG, Y.-F.; CHEN, Y.-X., 2012. Dehydration melting of ultrahighpressure eclogite in the Dabie orogen: evidence from multiphase solid inclusions in garnet. Journal of metamorphic geology, 30: 193-212.

Grohmann, C.H. \& Campanha, G.A.C., 2010. OpenStereo: open source, crossplatform software for structural geology analysis. Presented at the AGU 2010 Fall Meeting, San Francisco, CA.

Gutscher, M-A.; Spakman, W.; Bijwaard, H.; Engdhal, E.R., 2000a. Geodynamics of flat subduction: Seismicity and tomographic constraints from the Andean margin. Tectonics, 19(5): 814-833. 
Gutscher, M-A.; Maury, R.; Eissen, J-P.; Bourdon, E., 2000b. Can slab melting be caused by flat subduction? Geology, 28(6): 535-538.

Hachspaker, P.C.; Fetter, A.H.; Ebert, H.D.; Janasi, V.A.; Dantas, E.L.; Oliveira, M.A.F.; Braga, I.F.; Negri, F.A., 2003. Magmatismo há ca. 660-640 Ma no Domínio Socorro: registro de convergência pré-colisional na aglutinação do Gondwana Ocidental. Geol. USP, Ser. Cient., 3(1): 85-96.

Haddad, R.C., 1995. O batólito granitóide Pinhal-Ipuiúna (SP-MG): um exemplo do magmatismo cálcio-alcalino potássico neoproterozóico no sudeste brasileiro. Tese de Doutoramento, Instituto de Geociências, Universidade de São Paulo, $270 \mathrm{pp}$.

Harley, S.L.; Kelly, N.M.; Moller, A., 2007. Zircon behaviour and the termal histories of mountain chains. Elements, 3: 25-30.

Heilbron, M., Pedrosa-Soares, A.C., Campos Neto, M.C., Silva, L.C., Trouw, R.A.J., Janasi, V.A., 2004. Província Mantiqueira. In: V. Mantesso-Neto, A. Bartorelli, C.D.R. Carneiro, B.B.Brito-Neves (Eds), GEOLOGIA DO CONTINENTE SULAMERICANO, Capítulo XIII. Beca, 204-234.

Hokada, T. \& Harley, S.L., 2004. Zircon grouwth in UHT leucosome: constraints from zircon-garnet rare earth element relations in Napier Complex, East Antarctica. Journal of Mineralogical and Petrological Sciences, 99: 180-190.

Holmquist, P.J., 1916. Swedish Archean structures and their meaning. Bulletin of the Geological Institute Upsala, 15: 125-148.

Holness, M.B. \& Sawyer, E.W., 2008. On the pseudomorphing of melt-filled pores during the crystallization of migmatites. Jourmal of Petrology, 49(7): 1343-1363.

Holnes, M.B.; Cesare, B.; Sawyer, E.W., 2011. Melted rocks under the microscope: Microstructures and their interpretations. Elements, 7: 247-252.

Irvine, T.N. \& Baragar, W.R.A., 1971. A guide to the chemical classification of the comom volcanic rocks. Canadian Journal of Earth Sciences, 8: 523-548.

Isozaki, Y.; Aoki, K.; Nakama, T.; Yanai, S., 2010. New insights into a subductionrelated orogen: A reappraisal of the geotectonic framework and evolution of the Japonese Islands. Gondwana Research, 18: 82-105.

Jaillard, E.; Hérail, G.; Monfret, T.; Díaz-martinez, E.; Baby, P.; Lavenu, A. Dumont, J.F., 2000. Tectonic Evolution of the Andes of Ecuador, Peru, Bolivia and Northermost Chile. In: Cordani, U.G., Milani, E.J., Thomaz Filho, A. e Campos, 
D.A. TECTONIC EVOLUTION OF SOUTH AMERICA, $31^{\text {ST }}$ International Geological Congress: 481-589.

Jamieson, R. A.; Unsworth, M.J.; Harris, N.B.W.; Rosenberg, C.L.; Schulmann, K., 2011. Crustal melting and the flow of mountains. Elements, 7: 253-260.

Janasi, V.A., 1986. Geologia e petrologia do maciço monzodiorítico-monzonítico de

Piracaia-SP. Dissertação de mestrado, Instituto de Geociências, Universidade de São Paulo, 281pp.

Janasi, V.A., 1993. Petrogenesis and tectonic setting of the Neoproterozoic Capituva K-syenitic massif. SW Minas Gerais, Brazil. Revista Brasileira de Geociências, 23(2): 129-138.

Janasi, V.A., 1997. Crustal anatexis and granite genesis in the Socorro-Guaxupé Thrust Nappe, southeastern Brazil: some constraints from elemental geochemistry. Revista Brasileira de Geociências, 27(1): 139-150.

Janasi, V.A., 1999. Petrogênese de granitos crustais na Nappe de Empurrão Socorro-Guaxupé (SP-MG): Uma contribuição da geoquímica elemental e isotópica. Tese de Livre-Docência, Instituto de Geociências, Universidade de São Paulo, 304 pp.

Janasi, V.A., 2002. Elemental and $\mathrm{Sm}-\mathrm{Nd}$ isotope geochemistry of two Neoproterozoic mangerite suits in SE Brazil: implications for the origin of mangerite-charnockite-granite series. Precambrian Research, 119: 301-327.

Janasi, V. A. \& Ulbrich, H.H.G.J., 1991. Late proterozoic granitoid magmatism in the State of São Paulo, southeastern Brazil. Precambrian Research, 51: 351-374.

Janasi, V.A; Vlach, S.R.F; Ulbrich, H.H.G.J, 1993. Enriched-mantle contributions to the Itu granitoid belt, SE Brazil: evidence from k-rich diorites and syenites. Anais da Academia Brasileira de Ciências, 65 (suplem.1): 107-118.

Janasi, V.A.; Vlach, S.R.F.; Campos Neto, M.C.; Ulbrich, H.H.G.J., 2009. Associated A-type subalkaline and high-K calc-alkaline granites in the Itu Granite Province, southeastern Brazil: petrological and tectonic significance. The Canadian Mineralogist, 47: 1505-1526.

Janoušek, V.; Farrow, C.M.; Erban, V., 2006. Interpretation of whole-rock geochemical data in igneous geochemistry: Introducing Geochemical Data ToolKit (GCDKit). Journal of Petrology, 47: 1255-1259.

Jones, K.A. \& Brown, M., 1990. High-temperature clockwise P-T paths and melting in the development of regional migmatites: an example from Southern Brittany, France. Journal of Metamorphic Geology, 8(5): 551-578. 
Kelly, N.M. \& Harley, S.L., 2005. An integrated microtextural and chemical approach to zircon geochronology: refining the Archean history of the Napier Complex, east Antarctica. Contributions to Mineralogy and Petrology, 149: 57-84.

Kemp, A.I.S.; Hawkesworth, C.J.; Paterson, B.A.; Kinny, P.D., 2006. Episodic growth of the Gondwana supercontinent from Hafnium and Oxigen isotopes in zircon. Nature, 439: 580-583.

Korhonen, F.J., Saito, S., Brown, M. Siddoway, C.S. 2010. Modeling multiple melt loss events in the evolution of an active continental margin. Lithos, 116: 230248.

Kinny, P.D. \& Maas, R., 2003. Lu-Hf and Sm-ND isotope systems in zircon. In: HANCHAR, J.M. \& HOSKIN, P.W.O. (eds): ZIRCON. Reviews in mineralogy and geochemistry, 53: 327-341.

Kretz, R., 1983. Symbols of rock-forming minerals. American Mineralogist, 68: 277279.

Kriegsman, L.M. \& Álvarez-Velasco, A. 2010. Melt-producing versus melt-consuming reactions in pelitic xenoliths and migmatites. Lithos, 116: 310-320.

Kruse, R. \& Stunitz, H., 1999. Deformation mechanisms and phase distribution in mafic high-temperature mylonites from the Jotun Nappe, Southern Norway. Tectonophysics, 303: 223-249.

Le Breton, N. \& Thompson, A.B., 1988. Fluid-absent (dehydration) melting of biotite in metapelites in the early stages of crustal anatexis. Contrib. Mineral. Petrol., 99: 226-237.

Marchildon, N. \& Brown, M., 2002. Grain-scale melt distribution in two contact aureole rocks: implications for controls on melt localization and deformation. Journal of Metamorphic Geology, 20: 381-396.

Martins, L.; Vlach, S.R.F.; Janasi, V.A., 2009. Reaction microtextures of monazite: correlation between chemical and age domains in the Nazaré Paulista migmatite, SE Brazil. Chemical Geology, 261: 271-285.

Maruyama, S., Masago, H., Katayama, I., Iwase, Y, Toriumi, M., Omori, S. \& Aoki, K., 2010. A new perspective on metamorphism and metamorphic belts. Gondwana Research, 18: 106-137.

Nebel, O.; Nebel-Jacobson, Y.; Mezger, K.; Berndt, J., 2007. Initianl Hf isotope compositions in magmatic zircon from early Proterozoic rocks from the Gawler Craton, Australia: A test for zircon model ages. Chemical Geology, 241: 23-37. 
Morales, N.; Hasui, Y.; Zanardo, A., 2005. Evolução tectônica do cinturão de cisalhamento Campo do Meio baseada nos indicadores de sentido de cisalhamento. X Simpósio Nacional de Estudos Tectônicos (Curitiba), Anais, 432-435.

Mori, P.E.; Reeves, S.; Correia, C.T.; Haukka, M., 1999. Development of a fused glass disc XRF facility and comparison with pressed powder pellet technique at Instituto de Geosciências, São Paulo University. Revista Brasileira de Geociências, 29: 441-446.

Moores, E.M. \& Twiss, R.J., 1995. Tectonics. New York: W.H. Freeman \& Co., 415p. Moyen, J-F., 2009. High $\mathrm{Sr} / \mathrm{Y}$ and La/Yb ratios: the meaning of the "adakitic signature". Lithos, 112: 556-574.

Navarro, M.S.; Andrade, S.; Ulbrich, H.; Gomes, C.B.; Girardi, V.A.V., 2008. The Direct Determination of Rare Earth Elements in Basaltic and Related Rocks using ICP-MS: Testing the Efficiency of Microwave Oven Sample Decomposition Procedures. Geostandards and Geoanalytical Research, 32(2): 167-180.

Negri, F.A. \& Oliveira, M.A.F., 2005. Geoquímica e geotermometria dos granulitos máficos associados às rochas supracrustais da extremidade meridional do Domínio Socorro, região de São Francisco Xavier, SP. Revista Brasileira de Geociências, 35: 591-602.

O'Connor, J. T., 1965. A classification for quartz-rich igneous rocks based on feldspar ratios. In: US Geological Survey Professional Paper, B525. USGS, 7984.

Oliveira, M.A.F. 1973. Petrologia das Rochas Metamórficas da Região de São José do Rio Pardo, SP. Rev. Bras. Geoc., 3(4): 257-178.

Oliveira, M.A.F.; Morales, N.; Zanardo, A.; Carvalho, S.G., 1989. Mapeamento geológico em 1:25.000 do quadrante nordeste da Folha Caconde (SF-23-V-C-VI2-NO).

Orts, D.L.; Folguera, A.; Encinas, A.; Ramos, M.; Tobal, J.; Ramos, V.A., 2012. Tectonic development of the North Patagonian Andes and their related Miocene foreland basin $\left(41^{\circ} 30^{\prime}-43^{\circ} S\right)$. Tectonics, 31: TC3012, doi:10.1029/ 2011 TC003084

Pattison, D.R.M.; Chacko, T.; James, F.; McFarlane, C.R.M., 2003. Temperatures of granulite-facies metamorphism: Constraints from experimental phase equilibria 
and thermobarometry corrected for retrograde exchange. Journal of Petrology, 44(5): 867-900.

Peccerillo, A. \& Taylor, S. R., 1976. Geochemistry of Eocene calc-alkaline volcanic rocks from the Kastamonu area, Northern Turkey. Contributions to Mineralogy and Petrology, 58: 63-81.

Peternel, R.; Trouw, R.A.J.; Schmitt, R., 2005. Interferência entre duas faixa móveis neoproterozóicas: o caso das faixas Brasília e Ribeira no sudeste do Brasil. Revista Brasileira de Geociências, 35(3): 297-310.

Pluijm, B.A.V.D \& Marshak, S., 2004. Earth Structure: An introduction to structural geology and tectonics. New York: W.W. Norton \& Company, $2^{a}$ Ed., 656p.

Pope, D.C. \& Willett, S.D., 1998. Thermal-mechanical model for crustal thickening in the central Andes driven by ablative subduction. Geology, 26: 511-514.

Pryer, L.L.,1993. Microstructures in feldspars from a major crustal thrust zone: The Greenville Front, Ontario, Canada. Journal of Structural Geology, 15(1): 21-36.

Ramos, V.A.; Cristallini, E.O.; Pérez, D.J., 2002. The Pampean flat-slab of the Central Andes. Journal of South American Earth Sciences, 15: 59-78.

Ramos, V.A., 2009. Anatomy and global context of the Andes: main geologic features and the Andean orogenic cycle. In: Kay, S.M.; Ramos, V.A.; Dickinson, W.R. (eds): BACKBONE OF THE AMERICAS: SHALLOW SUBDUCTION, PLATEAU UPLIFT AND RIDGE AND TERRANE COLLISION. Geological Society of America Memoir, 204: 31-65.

Reno, B.L.; Brown, M.; Kabayashi, K.; Nakamura, E.; Picolli, P.M.; Trouw, R.A.J., 2009. Eclogite-high-pressure granulite metamorphism records early collision in West Gondwana: new data from the southern Brasília Belt, SE Brazil. Journal of the Geological Society, London, 166: 1013-1032.

Roberts, M.P \& Finger, F., 1997. Do U-Pb zircon ages from granulites reflect peak metamorphic conditions? Geology, 25: 319-322.

Rosenberg, C.L. \& Stunitz, H., 2003. Deformation and recrystallization of plagioclase along a temperature gradient: an example of the Bergell Tonalite. Journal of Structural Geology, 25: 389-408.

Sato, K.; Tassinari, C.C.G.; Kawashita, K.; Petronilho, L., 1995. O método geocronológico Sm-Nd no IG/USP e suas aplicações. Anais da Academia Brasileira de Ciencias, 67: 315-336. 
Scarrow, J.H.; Bea, F.; Montero, P.; Molina, J.F., 2009. Shoshonites, vaugnerites and potassic lamprophyres: similarities and differences between 'ultra'-high-K rocks. Earth and Env. Sci. Trans. of the Royal Soc. of Endinburg, 99: 159-175.

Sawyer, E.W., 1999. Criteria for the recognition of partial melting. Physics and Chemistry of the Earth, 24: 269-279.

Sawyer, E.W., 2001. Melt segregation in the continental crust: distribution and movement of melt in anatetic rocks. Journal of Metamorphic Geology, 19: 291301.

Sawyer, E.W., 2008. Atlas of migmatites. The Canadian Mineralogist. In: Special Publication, vol. 9. NRC Research Press, Ottawa, Ontario, p. 371.

Sawyer, E.W. 2010. Migmatites formed by water-fluxed partial melting of a leucogranodiorite protolith: Microstructures in the residual rocks and source of the fluid. Lithos, 116, 273-286.

Shand S.J., 1943. Eruptive Rocks: Their Genesis, Composition, Classification, and their Relation to Ore Deposits, with a chapter on Meteorites (revised second edition): Hafner Publishing Co., New York, 444p.

Souza, S.L., 2009. Métodos radiométricos Rb-Sr e Sm-Nd no CPGeo Igc-USP. In: Simpósio 45 anos de Geocronologia no Brasil, 2009, São Paulo. Boletim de Resumos Expandidos: 137-139.

Steiger, R.H. \& Jaeger, C., 1978. Subcomission on geochronology: convention of the use of decay constants in geochronology and cosmochronology. Contributions to the geologic time scale. Studies in Geology, 6: 67-72.

Şengör, A.M.C., 1990. Plate Tectonics and Orogenic Research after 25 years: A Tethyan Perspective. Earth Science Reviews, 27: 1-201.

Şengör, A.M.C. 1991. Plate Tectonics and orogenic research after 25 years: Synopsis of a Tethyan perspective. Tectonphysics, 187, 315-344.

Schurr, B.; Rietbrock, A.; Asch, G.; Kind, R.; Oncken, O., 2006. Evidence for lithospheric detachment in the central Andes from local earthquake tomography. Tectonophysics, 415: 203-223.

Sizova, E.; Gerya, T.; Brown, M.; Perchuk, L.L., 2010. Subduction styles in the Precambrian: Insight from numerical experiments. Lithos, 116: 209-229.

Sobolev, S.V. \& Babeyko, A.Y., 2005. What drives orogeny in the Andes? Geology, 33: $617-620$.

Stipp, M.; Stunitz, H.; Heilbronner, R.; Schmid, S.M., 2002. The eastern Tonale Fault Zone: a natural laboratory for Crystal plastic deformation of quartz over a 
temperature range from $250^{\circ}$ to $700^{\circ} \mathrm{C}$. Journal of Structural Geology, 24: 1861 1884.

Teixeira, W.; Sabaté, P.; Barbosa, J.; Noce, C.M.; Carneiro, M.A., 2000. Arcehan and paleoproterozoic evolution of the São Francisco Craton, Brazil. In. Cordani, U.G.,Milani, E.J., Thomaz Filho, A., Campos, D.A. (Eds.), TECTONIC EVOLUTION OF SOUTH AMERICA. 31th International Geological Congress, Rio de Janeiro, Brazil, pp. 101-137.

Thompson, A.B., 1999. Some time-space relationships for crustal melting and granitic intrusion at various depths. In: Castro, A.; Fernández, C.; Vigneresse, J.L. (eds.): UNDERSTANDING GRANITES. INTEGRATING NEW AND CLASSICAL TECHIQUES. Geological Society of London Special Publication, 168: 7-25.

Thompson, A.B. \& Connolly, J.A.D., 1995. Melting of the continental crust: Some termal and petrological constraints on anatexis in continental collision zones and other tectonic settings. Jourmal of Geophysical Research, 100: 1556515579.

Tichomirowa, M.; Whitehouse, M.J.; Nasdala, L., 2005. Resorption, growth, solidstate recrystallisation and annealing of granulite-facies zircon - a case study from the Central Erzgebirge. Lithos 82(1-2): 25-50.

Topfner, O.F., 1996. Brasiliano-granitoide in den Bundasstaaten São Paulo und Minas Gerais, Brasilien-eiene Vergleichende studie. Munchner Geol. Hefte, A17: $258 \mathrm{p}$.

Torquato, Jr. \& Kawashita, K., 1994 . Geologia Nuclear V - O método Rb/Sr. Revista de Geologia, 7: 91-123 .

Trouw, R.A.J.; Heilbron, M.; Ribeiro, A.; Paciullo, F.; Valeriano, C.M., Alemida, J.C.H.; Tupinambá, M.; Andreis, R.R., 2000. The central segment of Ribeira Belt. In: Cordani, U.G., Milani, E.J., Thomaz Filho, A., Campos, D.A. (Eds.), TECTONIC EVOLUTION OF SOUTH AMERICA. 31th International Geological Congress, Rio de Janeiro, Brazil, pp. 287-310.

Trouw, R.A.J.; Heilbron, M.; Peternel, R.; Ribeiro, A.; Vinagre, R.; Duffles, P.; Trouw, C., 2011. A new interpretation for the interference zone between the southern Brasilia Belt and the Central Ribeira Belt, SE Brazil. 13ํㅗㅇósio Nacional de Estudo Tectônicos/VII International Symposium on Tectonics (Campinas/SP), Anais, 141-144. 
Vavra, G.; Schmid, R.; Gabauer, D., 1999. Internal morphology, habit and U-Th-Pb microanalysis of amphibolite-to-granulite facies zircons. Contributions to mineralogy and petrology 134(4): 380-404.

Vernon, R.H. \& Clarke, G.L., 2008. Principles of Metamorphic Petrology. Cambridge University Press, 446p.

Vignaresse, J.L., 2004. A new paradigm for granite generation. Transactions of the Royal Society of Endinburgh: Earth Sciences, 95: 11-22.

Vlach, S.R.F.; Janasi, V.A.; Vasconcellos, A.C.B.C., 1990. The Itu Belt: associated calc-alkaline and aluminous A-type late Brasiliano granitoids in the states of São Paulo and Paraná, southern Brazil. Congresso Bras. Geol. XXXVI (Nata), Anais 4, 1700-1711.

Vlach, S.R.F. \& Gualda, G.A.R., 2000. Micropobe monazite dating and ages of some granitic and metamorphic rocks from southeastern Brazil. Revista Brasileira de Geociências, 30: 214-218.

Watson, E.B. \& Harrison, T.M., 1983. Zircon saturation revised: temperature and composition effects in a variety of crustal magma types. Earth Planet. Sci. Lett., 64: 295-304.

Wernick, E. \& Penalva, F., 1980. O Grupo Pinhal na região nordeste do Estado de São Paulo e áreas vizinhas do Estado de Minas Gerais. Boletim IG, Instituto de Geociências USP, 11: 1-20.

Wernick, E.; Weber-Diefenbach, K.; Correia, P.R., 1987. O graniteide Nazaré Paulista: dados petrográficos, químicos e de tipologia do zircão. In: Simpósio Regional de Geologia, 6, Rio Claro-SP. Atas, SBG-SP, 1: 123-134.

Závada, P.; Schulmann, K.; Knopásek, J.; Illrich, S.; Lexa, O., 2007. Extreme ductility of feldspar aggegrates - Melt-enhanced boundary sliding and creep failure: Rheological implications for felsic lower crust. Journal of Geophysical Research, 122. Doi: $10.1029 / 2006 J B 004820$.

Zuquim, M.P.S.; Trouw, R.A.J.; Trouw, C.; Tohver, E., 2011. Structural evolution and $\mathrm{U}-\mathrm{Pb} \mathrm{SHRIMP}$ zircon ages of the Neoproterozoic Maria da Fé Shear Zone, central Ribeira Belt, SE Brazil. Journal of South American Earth Sciences, 31: 199-21 


\section{ANEXO I - MAPA LITOESTRUTURAL}

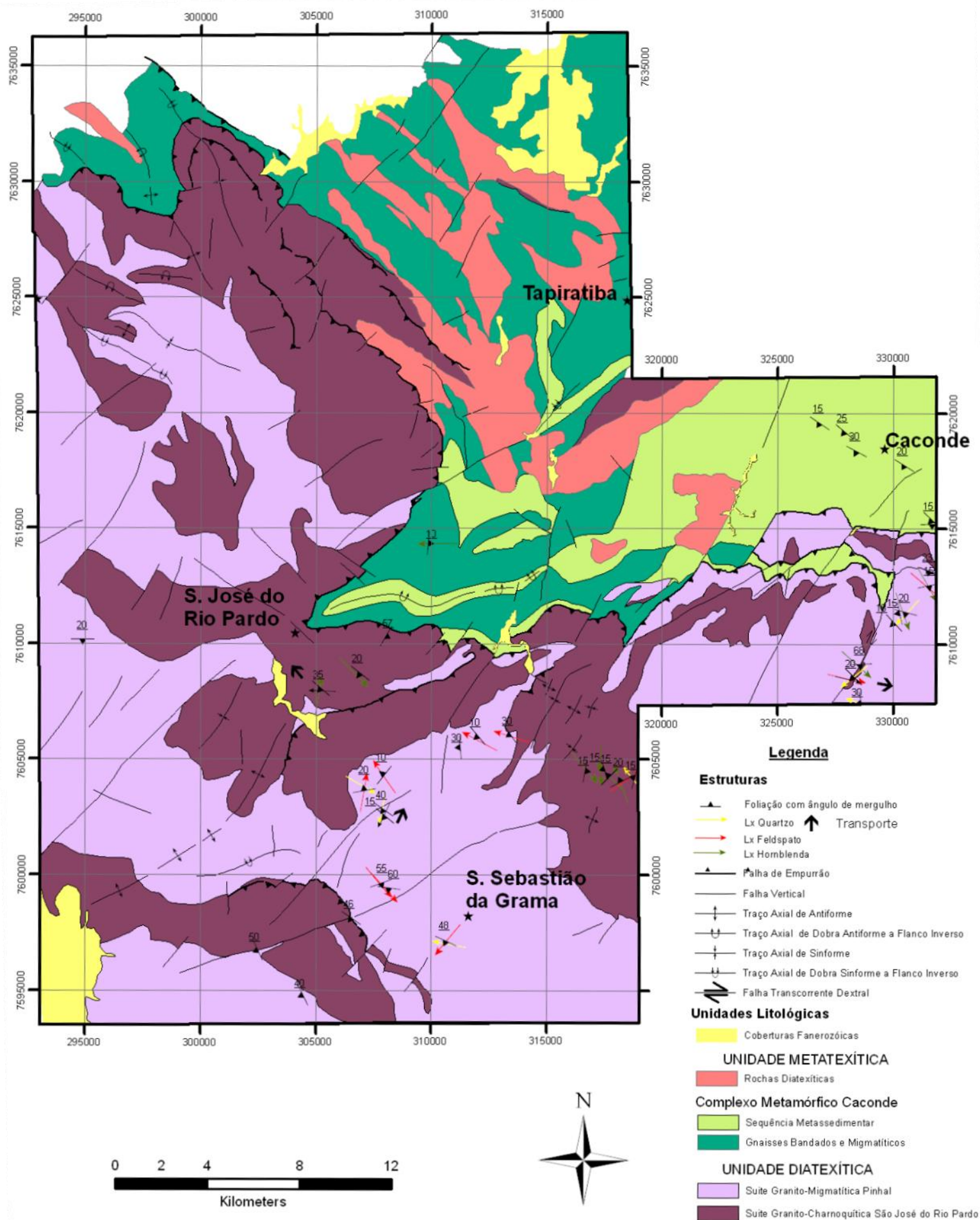




\section{ANEXO II - MAPA DE PONTOS}

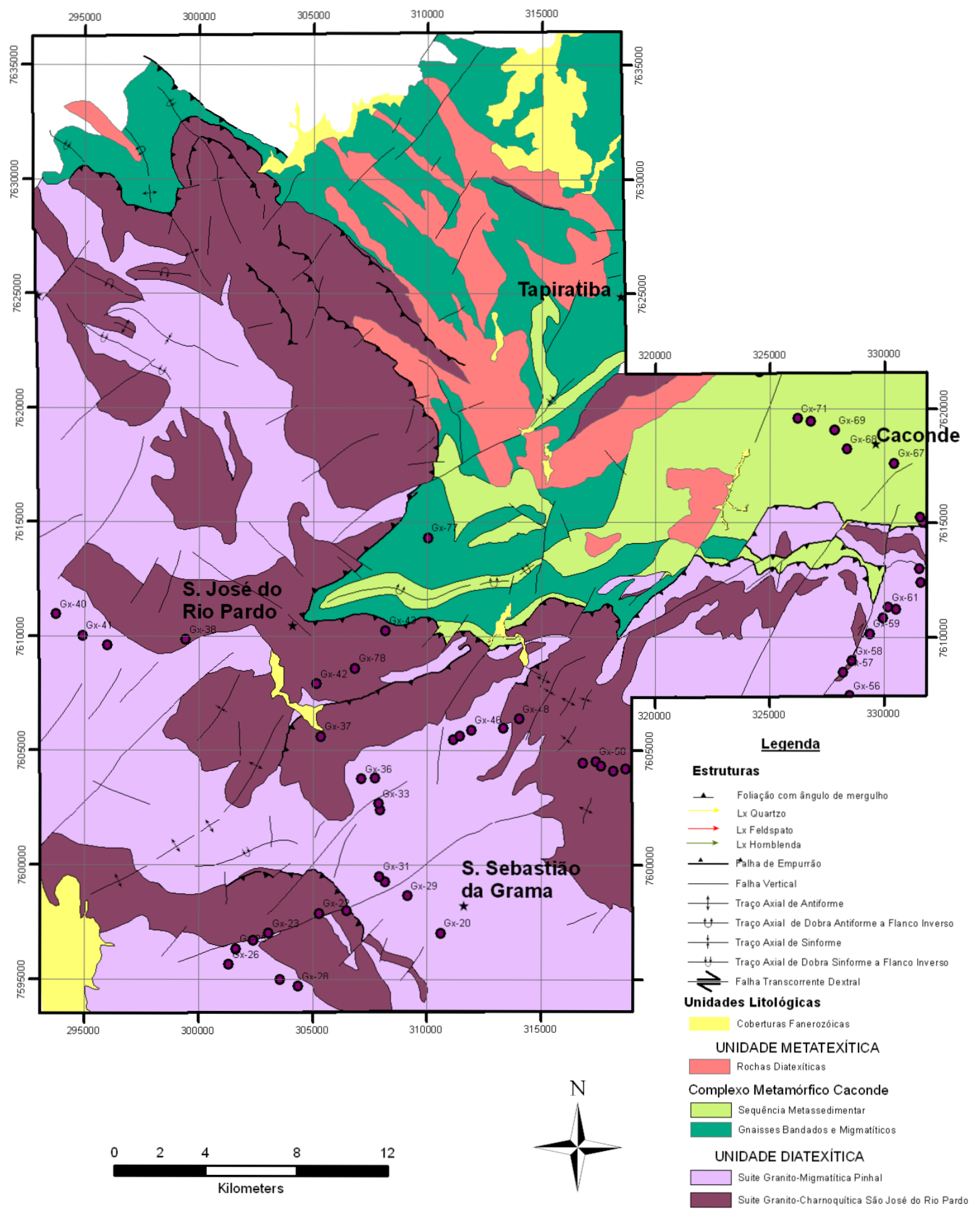

